\title{
HEAVY METAL ACCUMULATION IN MARINE FISHES IN PORIRUA HARBOUR
}

\author{
A thesis \\ submitted in partial fulfilment for the requirements \\ for the degree of Master of Science in Marine Biology
}

Liana Cook-Auckram

2019

School of Biological Sciences

Victoria University of Wellington

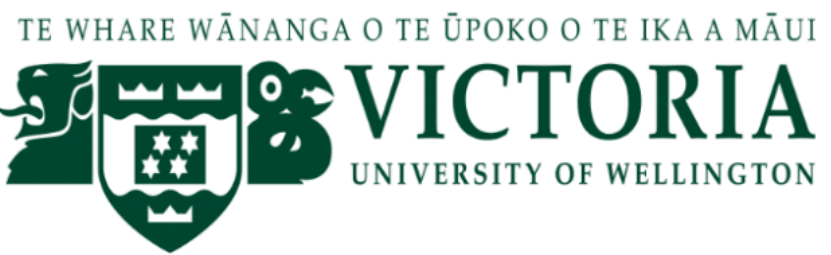




\section{Acknowledgments}

I would firstly like to acknowledge my primary supervisor Nicole Philips and my secondary supervisor Matt Dunn, I could not have asked for more supportive supervisors. Your endless advice and encouragement, together with thorough proof-reading of my thesis has been appreciated.

A special thank you to the NIWA scientists, especially Warrick Lyon whom went out of his way to provide advice on rig shark and field techniques. I would also like to acknowledge Darren Stevens and Peter Mcmillan for their expert assistance in flatfish aging and identification. I would also like to extend my gratitude to PhD candidate of the University of Waikato, Helen Cadwallader for her expert advice on stingrays and sending me biopsy tools to collect samples from the lower North Island for her thesis.

I would also like to thank the Victoria University Coastal Ecology (VUCEL), especially the tehnicians John Van der Sman and Daniel McNaughtan, who were always eager to provide me with resource and advice on laboratory procedures. I would also like to thank the VUCEL community (primarily Alison Duncan, Andrea Fagetti \& Paul Wolf) for being welcoming and providing statistics tutorials.

I would also like to thank all my field volunteers, in particular my brother, who helped me collect data in the field. Without them, I wouldn't have been able to complete my research to such a high standard.

I am incredibly grateful for the Greater Wellington Regional Council, particularly Dr. Megan Oliver, for their support and by providing the Science and Research Fund grant for my study, and to Turi Hippolite from Ngāti Toa for providing insight into the cultural significance of Te Awarua-o-Porirua Harbour.

Finally, I would like to thank my parents, Greg \& Leone for providing me with the love, support and encouragement to proceed in my scientific career. This accomplishment would not have been possible without them. Thank you. 


\section{Table of Contents}

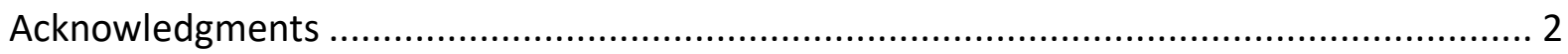

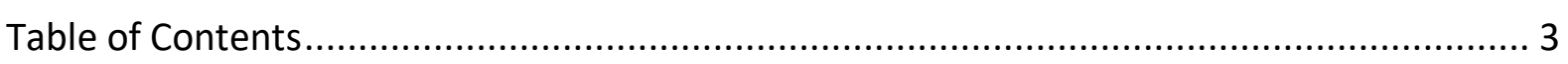

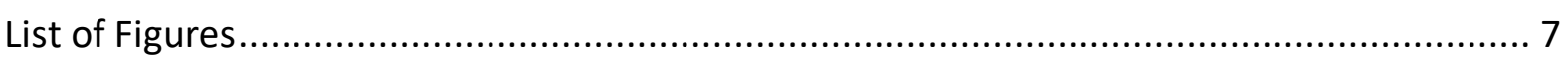

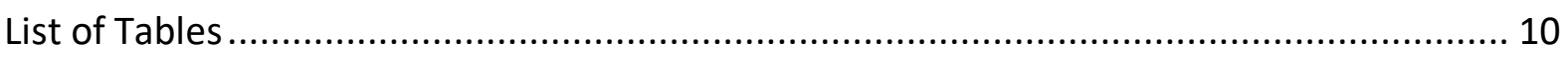

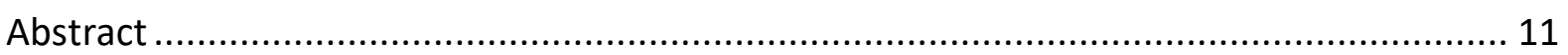

Chapter 1: Literature review on heavy metal accumulation in marine fishes .... 13

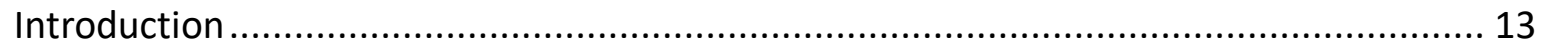

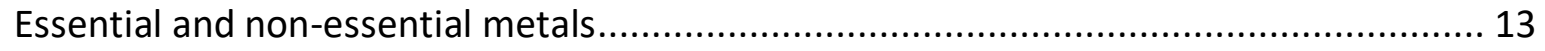

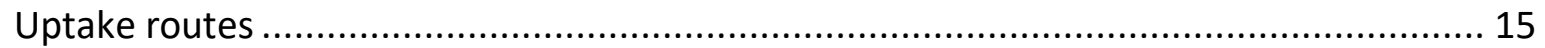

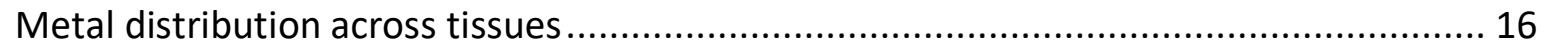

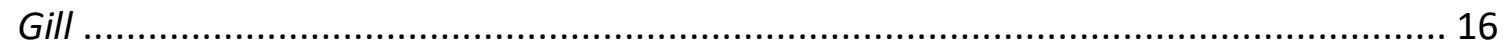

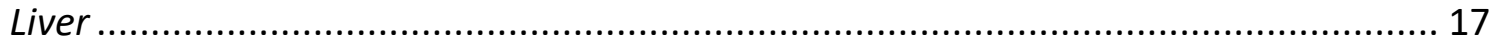

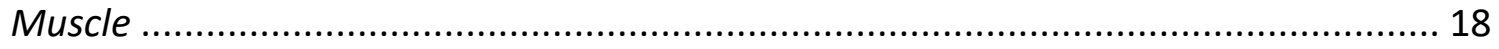

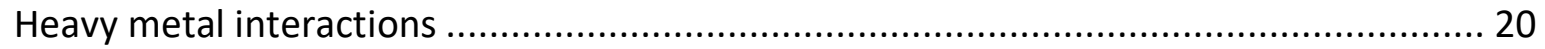

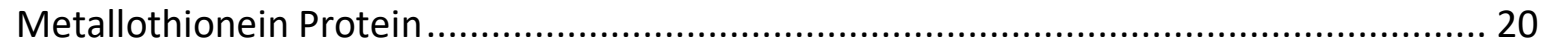

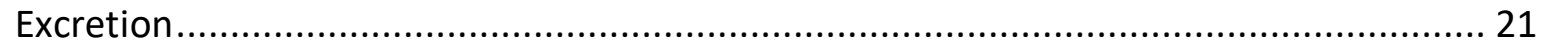

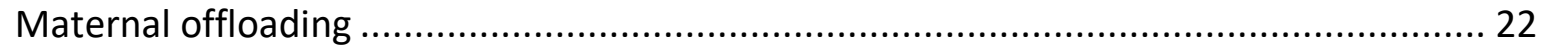

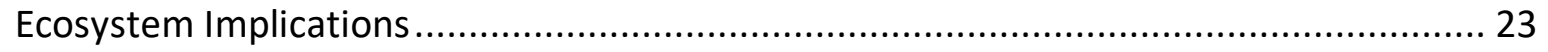

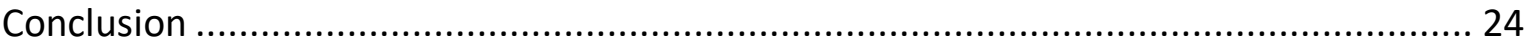

Chapter 2: Heavy metal accumulation in marine fishes in Porirua Harbour ...... 25

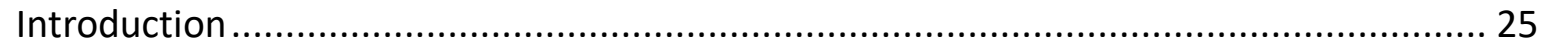

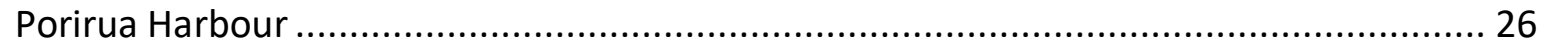

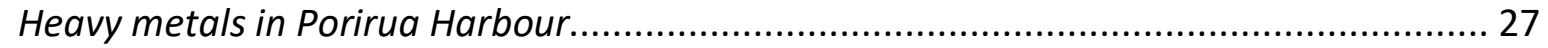

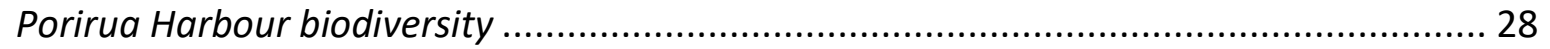

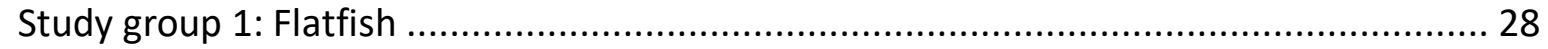

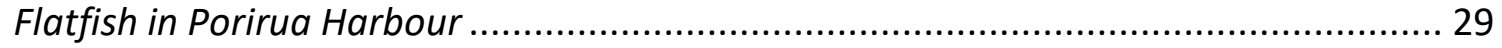

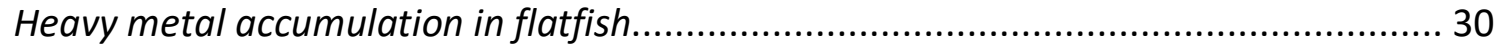

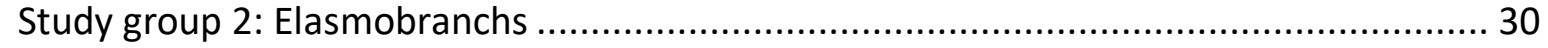

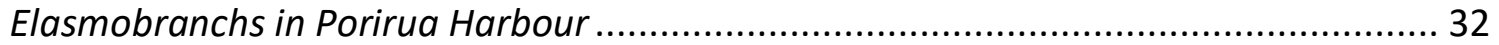

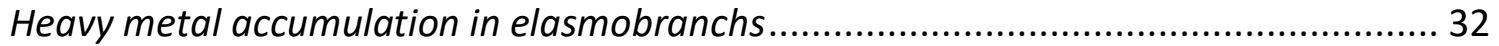

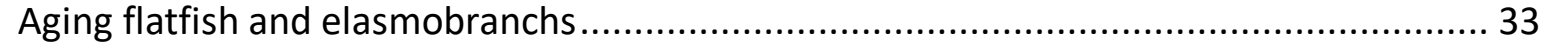

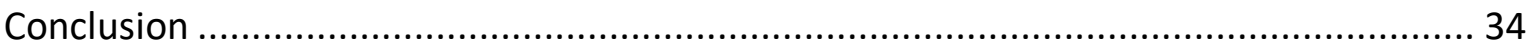

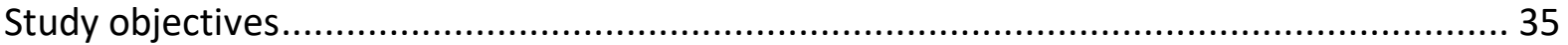

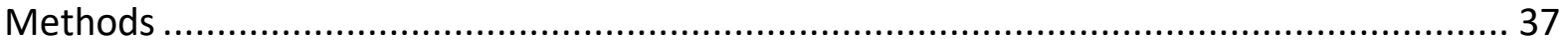




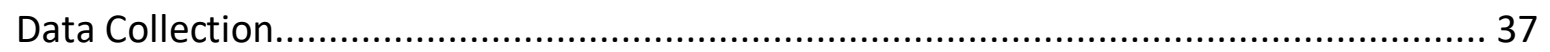

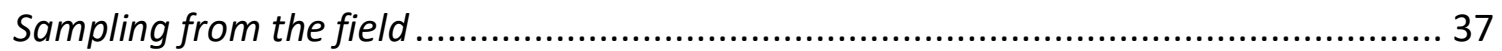

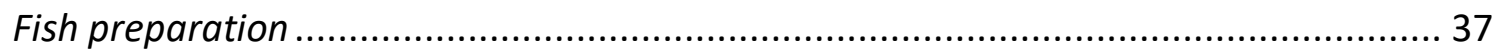

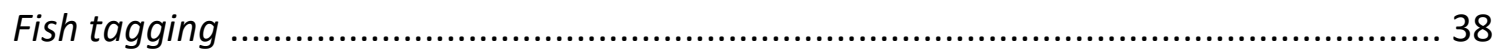

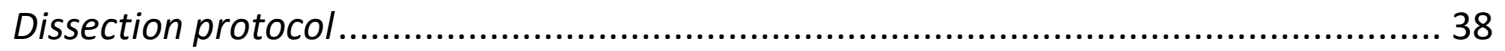

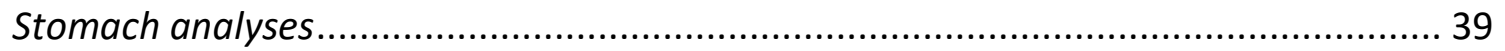

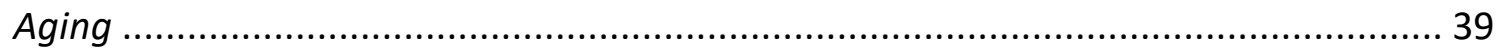

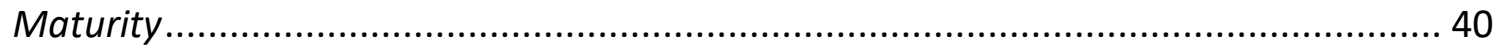

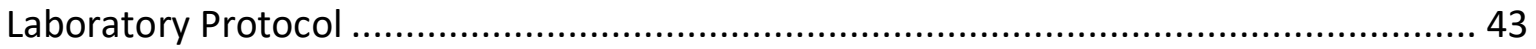

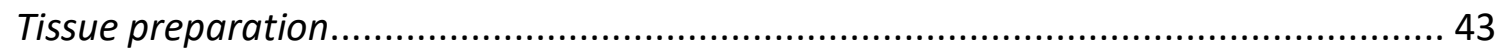

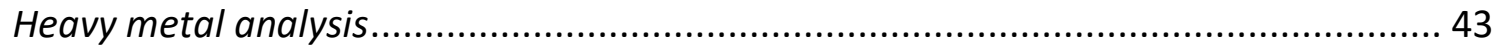

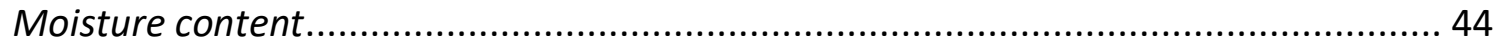

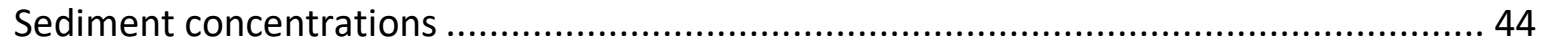

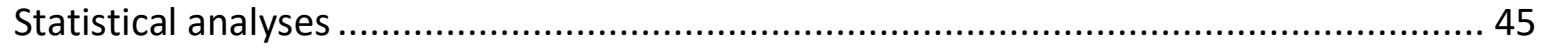

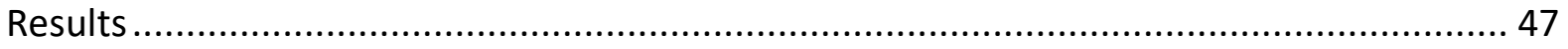

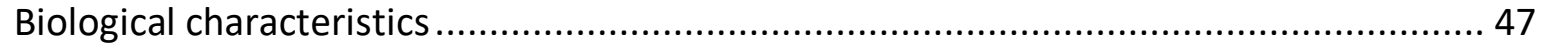

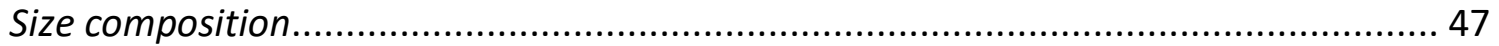

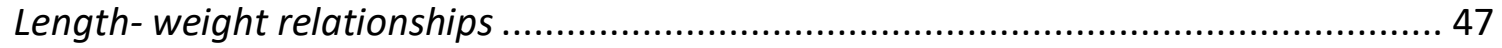

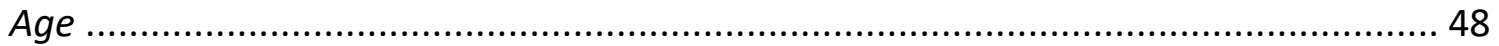

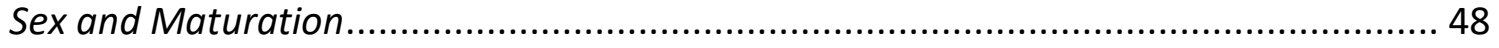

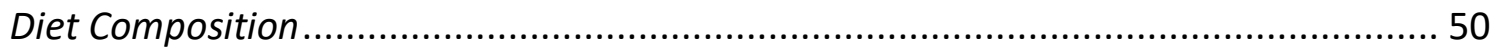

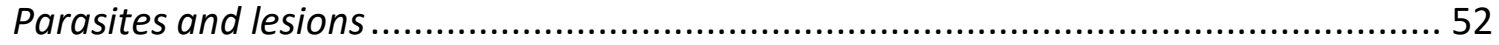

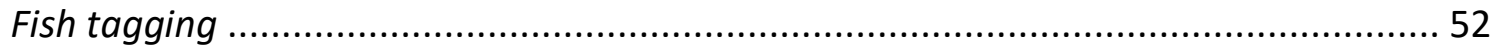

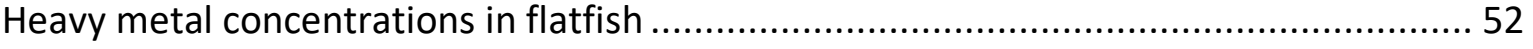

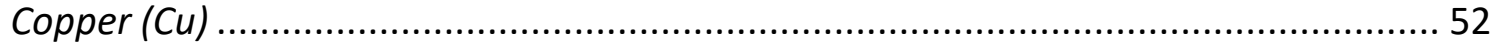

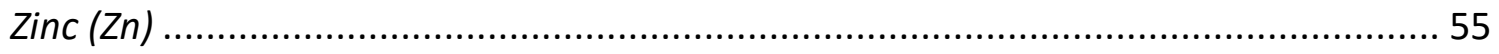

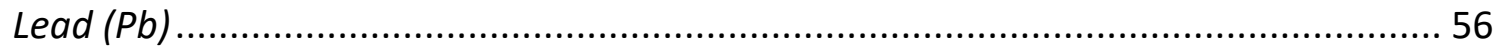

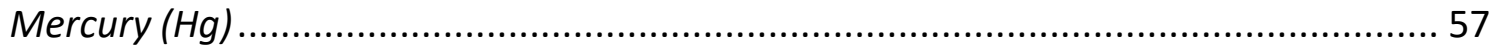

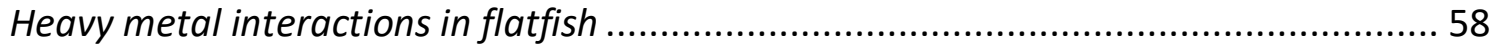

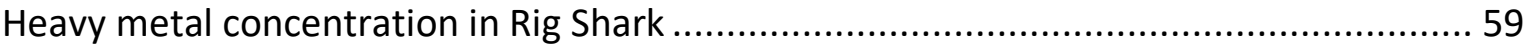

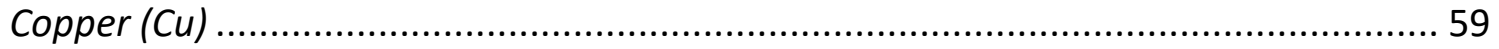

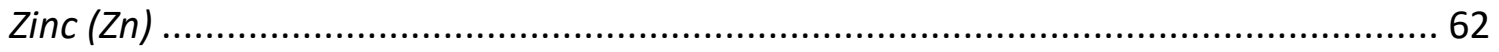

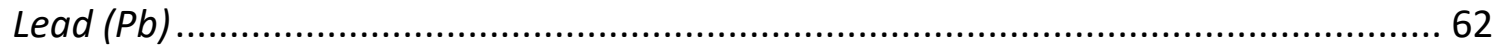

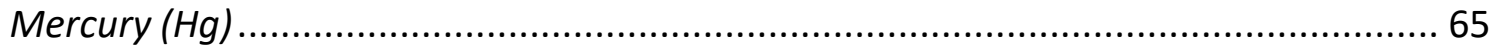

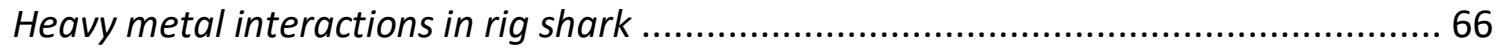




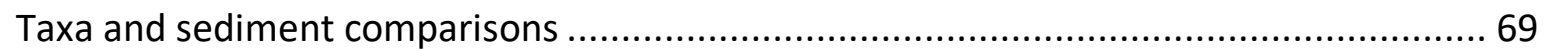

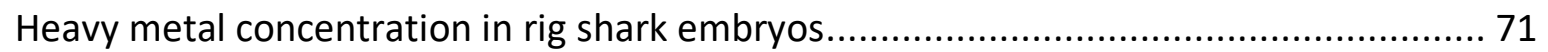

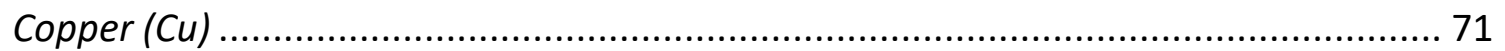

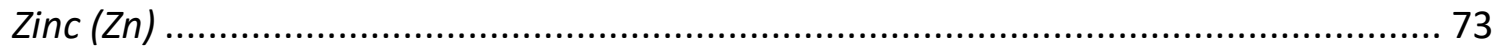

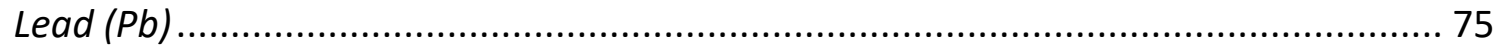

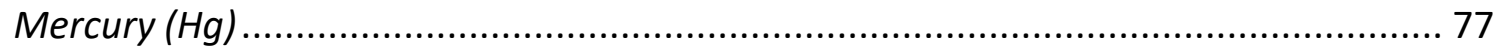

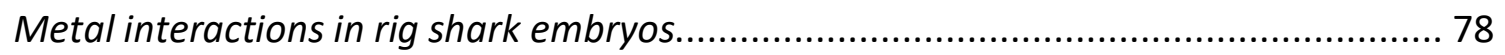

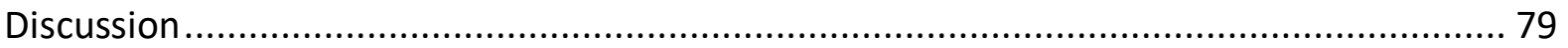

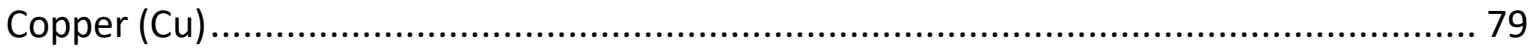

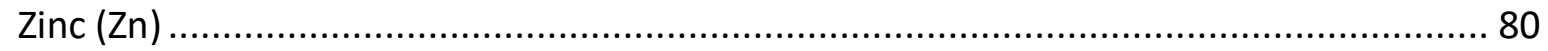

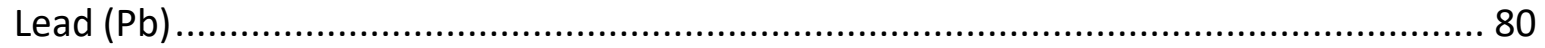

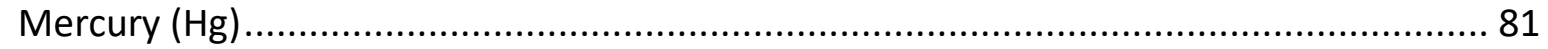

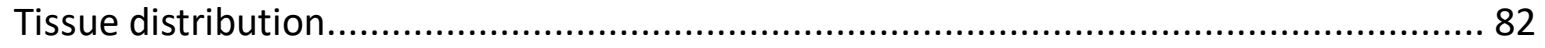

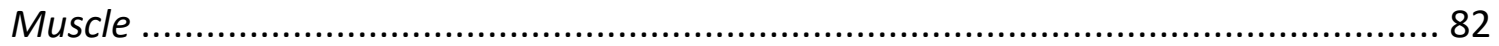

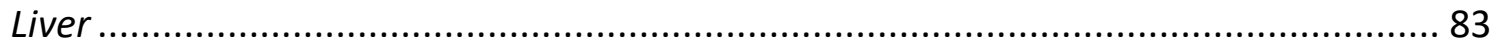

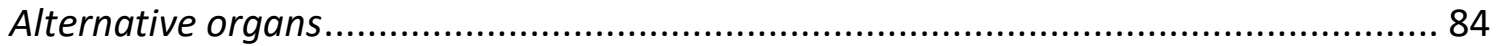

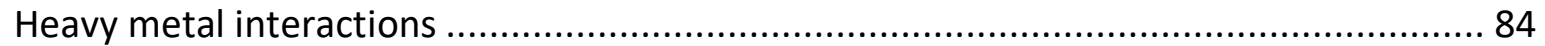

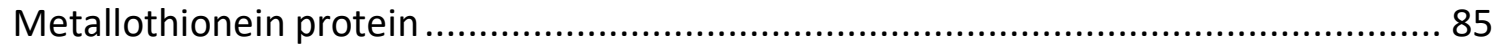

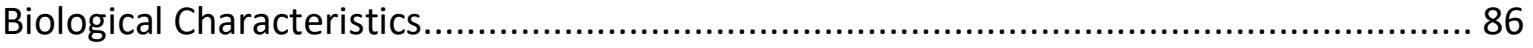

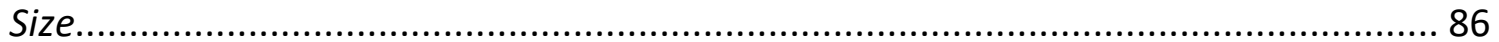

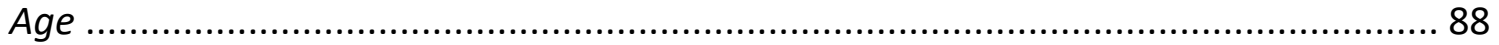

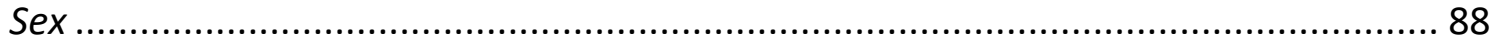

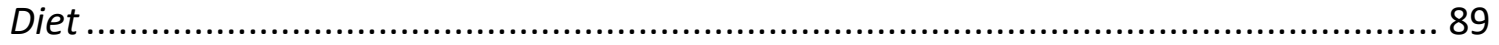

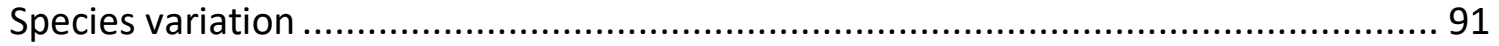

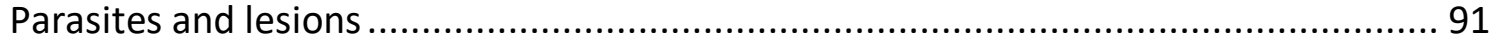

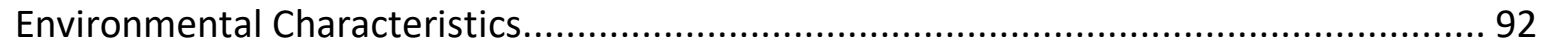

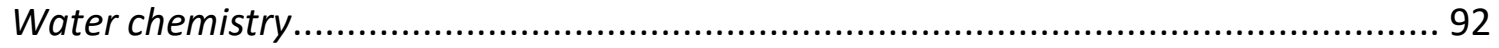

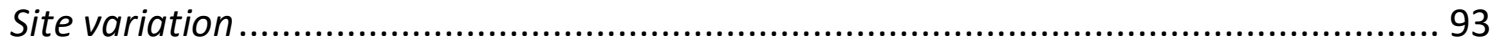

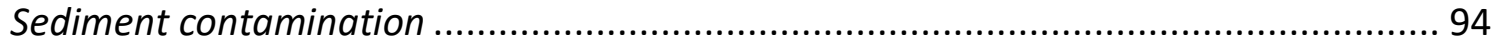

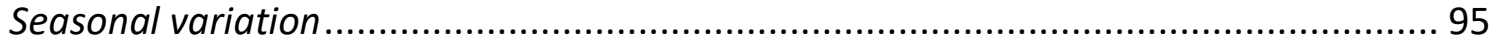

Maternal offloading in rig shark near-term embryos ............................................ 96

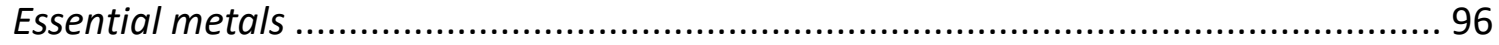

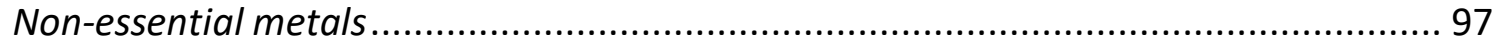

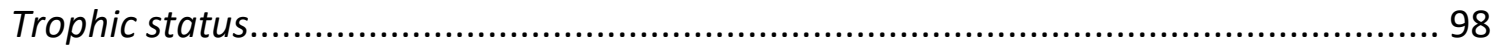




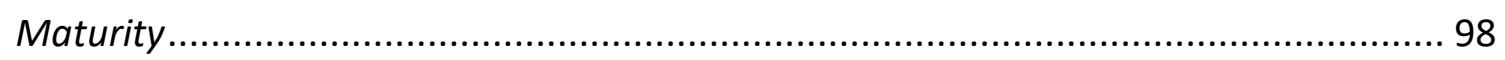

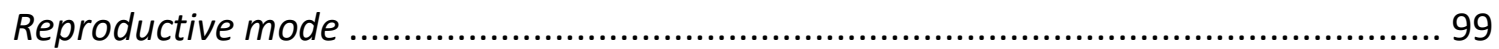

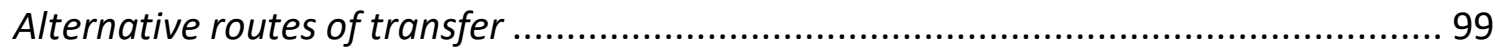

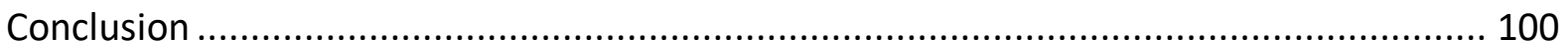

Recommendations for future research.................................................................... 102

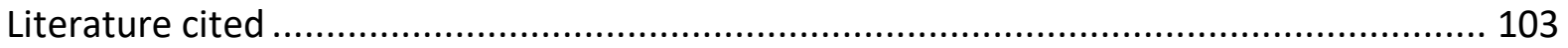

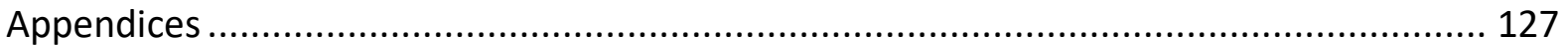




\section{List of Figures}

Figure 1: Arial photograph of Porirua Harbour located in the North Island of New Zealand, and the two estuary arms, Onepoto and Pauatahanui, sourced from Green, Stevens \& Oliver (2014). 26

Figure 2: Photograph a $16 \mathrm{~cm}$ female sand flounder, photographed by Liana Cook-Auckram.

Figure 3: Photograph of an adult rig shark, photographed by Malcolm Francis, NIWA....... 31

Figure 4: Photograph of Short tailed stingray (left) photographed by Andy Murch and eagle ray (right) photographed by Malcolm Francis, NIWA.

Figure 5: Arial map of sites sampled in Porirua Harbour. Wi Neera Drive, Titahi Bay Road and Onepoto Road (In Onepoto Arm), Ngati Toa Domain (Harbour entrance), Motukaraka Point and James Cook Drive (Pauatahanui Inlet). A flounder-spear was used at Ngati Toa Domain and James Cook Drive, and netting was used at all other sites. PORI 1-2 and PAH 1-3 are sites where sediments were sampled for heavy metals in $2015 / 2016$ by Oliver (2016). Retrieved from Google Earth 17/12/2018.

Figure 6: Photograph of a) adult rig shark, b) yellow belly flounder, and c) adult female rig shark and near-term embryos.

Figure 7: Total length- frequency distribution for a) yellow belly flounder, sand flounder, speckled sole $n=26$, b) elasmobranchs (rig shark, eagle ray, short tailed stingray) $n=26, c$ ) rig shark embryos $n=69$, collected from Porirua Harbour in 2018, excluding individuals that were tagged/released.

Figure 8: Length-weight linear and non-linear regression fit models for a) yellow belly flounder, sand flounder, speckled sole $n=26, b$ ) adult rig shark $n=21$ (green = pregnant females, red = pre-ovulatory females, black= males), and c) rig shark embryos collected from Porirua Harbour in 2018, excluding individuals that were tagged/released.

Figure 9: Sagittal otolith of a) $13 \mathrm{~cm}$ female sand flounder aged $0+$ years, b) $43 \mathrm{~cm}$ female yellow belly flounder aged $2+$ years, c) $12 \mathrm{~cm}$ female speckled sole aged $2+$ years.

Photographed by Liana Cook-Auckram.

Figure 10: The relationship between sex and weight ( $g$ ) for a) flatfish (yellow belly flounder and sand flounder), and b) rig shark caught from Porirua Harbour in 2018. Error bars represent standard errors.

Figure 11: The stalk-eyed mud crab H. hirtipes found in the stomach contents of a) yellow belly flounder (muscle and liver samples photographed) and b), c) rig shark.

Figure 12: The relationship between Cu concentrations $(\mathrm{mg} / \mathrm{kg} \mathrm{w} . \mathrm{w})$ in the muscle and liver tissue of flatfish with Total Length $(\mathrm{cm})$ and weight $(\mathrm{g})$ as the covariate. Red represents males and black indicates females.

Figure 13: Bar chart showing heavy metal concentrations $(\mathrm{Cu}, \mathrm{Zn}, \mathrm{Pb}, \mathrm{Hg}$ ) in flatfish tissue (muscle and liver) caught in Porirua Harbour in 2018. Error bars represent standard errors.

Figure 14: The relationship between $\mathrm{Zn}$ concentrations $(\mathrm{mg} / \mathrm{kg} \mathrm{w} . \mathrm{w})$ in the muscle and liver tissue of flatfish with Total Length $(\mathrm{cm})$ and weight $(\mathrm{g})$ as the covariate. Red represents males and black indicates females. 56

Figure 15: The relationship between $\mathrm{Pb}$ concentrations $(\mathrm{mg} / \mathrm{kg} \mathrm{w} . \mathrm{w})$ in the muscle and liver tissue of flatfish with Total Length $(\mathrm{cm})$ and weight $(\mathrm{g})$ as the covariate. Red represents males and black indicates females. 
Figure 16: The relationship between $\mathrm{Hg}$ concentrations $(\mathrm{mg} / \mathrm{kg} \mathrm{w} . \mathrm{w})$ in the muscle and liver tissue of flatfish with Total Length $(\mathrm{cm})$ and weight $(\mathrm{g})$ as the covariate. Red represents males and black indicates females. 58

Figure 17: The relationship between muscle $\mathrm{Cu}$ concentration and a) muscle $\mathrm{Hg}$, b) Liver $\mathrm{Hg}$, and the relationship between liver $\mathrm{Cu}$ concentration and c) muscle $\mathrm{Hg}$, b) liver $\mathrm{Hg}$ in flatfish. Results reported in $\mathrm{mg} / \mathrm{kg} \mathrm{w} . \mathrm{w}$. Red represents males and black indicates females. 59

Figure 18: The relationship between Cu concentrations $(\mathrm{mg} / \mathrm{kg} \mathrm{w} . \mathrm{w})$ in the muscle and liver tissue of rig shark with Total Length $(\mathrm{cm})$ and weight $(\mathrm{g})$ as the covariate. Red is preovulatory females, green is pregnant females and black is males.

Figure 19: Bar chart showing heavy metal $(\mathrm{Cu}, \mathrm{Zn}, \mathrm{Pb}, \mathrm{Hg}$ ) concentration (mg/kg w.w) in rig shark tissue (muscle and liver) caught in Porirua Harbour in 2018. Error bars represent standard errors.

Figure 20: The relationship between $\mathrm{Zn}$ concentrations $(\mathrm{mg} / \mathrm{kg} \mathrm{w} . \mathrm{w})$ in the muscle and liver tissue of rig shark with Total Length $(\mathrm{cm})$ and weight $(\mathrm{g})$ as the covariate. Red is preovulatory females, green is pregnant females and black is males.

Figure 21: The relationship between $\mathrm{Pb}$ concentrations $(\mathrm{mg} / \mathrm{kg} \mathrm{w} . \mathrm{w})$ in the muscle and liver tissue of rig shark with Total Length $(\mathrm{cm})$ and weight $(\mathrm{g})$ as the covariate. Red is preovulatory females, green is pregnant females and black is males

Figure 22: Barchart showing relationship between maturation/sex (male, pre-ovulatory female and pregnant female) and muscle Lead $(\mathrm{Pb})$ concentration in rig shark caught from Porirua Harbour in 2018. Error bars represent standard errors.

Figure 23: The relationship between $\mathrm{Hg}$ concentrations $(\mathrm{mg} / \mathrm{kg} \mathrm{w} . \mathrm{w})$ in the muscle and liver tissue of rig shark with Total Length $(\mathrm{cm})$ and weight $(\mathrm{g})$ as the covariate. Red is preovulatory females, green is pregnant females and black is males.

Figure 24: The relationship between the levels of a) muscle $\mathrm{Cu}$ and muscle $\mathrm{Zn}, \mathrm{b}$ ) liver $\mathrm{Zn}$ and liver $\mathrm{Pb}, \mathrm{c}$ ) liver $\mathrm{Zn}$ and muscle $\mathrm{Hg}$, d) Liver $\mathrm{Pb}$ and Liver $\mathrm{Hg}$, e) liver $\mathrm{Zn}$ and liver $\mathrm{Hg}$, f) muscle $\mathrm{Zn}$ and liver $\mathrm{Hg}$ in rig shark. Green = pregnant females, red = pre-ovulatory females, black= males. Results reported in $\mathrm{mg} / \mathrm{kg}$ w.w.

Figure 25: Barchart showing the relationship between heavy metals ( $\mathrm{Cu}, \mathrm{Zn}, \mathrm{Pb}, \mathrm{Hg}$ ) in tissue (muscle and liver) of rig shark, rays (eagle ray and short-tailed stingray) and flatfish caught from Porirua Harbour in 2018. Error bars represent standard errors.

Figure 26: Barchart showing the relationship between heavy metals $(\mathrm{Cu}, \mathrm{Zn}, \mathrm{Pb}, \mathrm{Hg}$ ) found in sediment samples sourced from Oliver (2016), and the concentration found in tissue (muscle and liver) of flatfish, rig shark and rays (short-tailed stingray and eagle ray) collected from Porirua Harbour. Error bars represent standard errors. 69

Figure 27: Bar chart showing a) concentration of essential metals ( $\mathrm{Cu}$ and $\mathrm{Zn}$ ) in mother and embryo tissues, $\mathrm{b}$ ) concentrations of non-essential metals $(\mathrm{Pb}$ and $\mathrm{Hg}$ ) in mother and embryo tissues of rig shark caught in Porirua Harbour. Error bars represent standard errors.

Figure 28: Relationship between Lead $(\mathrm{Pb})$ concentration mean \pm standard deviation in rig shark embryos and a) mother $\mathrm{Pb}$ muscle concentration, $\mathrm{b}$ ) mother $\mathrm{Pb}$ liver concentration $(\mathrm{mg} / \mathrm{kg} \mathrm{d.w})$ in rig shark caught in Porirua Harbour in 2018.

Figure 29: Relationship between Lead $(\mathrm{Pb})$ concentration mean \pm standard deviation in rig shark embryos and a) mother total Length $(\mathrm{cm})$, b) embryo total length $(\mathrm{cm}), \mathrm{c})$ mother weight ( $g)$, d) embryo weight $(g)$ in rig shark caught in Porirua Harbour. 
Figure 30: Relationship between Mercury $(\mathrm{Hg})$ concentration mean \pm standard deviation in rig shark embryo and a) mother $\mathrm{Hg}$ muscle concentration, b) mother $\mathrm{Hg}$ liver concentration $(\mathrm{mg} / \mathrm{kg} \mathrm{d.w})$ in rig shark caught in Porirua Harbour in 2018.

Figure 31: Relationship between Mercury $(\mathrm{Hg})$ concentration mean \pm standard deviation $\mathrm{mg} / \mathrm{kg} \mathrm{d}$.w in embryo and a) mother Total Length, b) Embryo Total Length in rig shark caught in Porirua Harbour in 2018.

Figure 32: Relationship between Mercury $(\mathrm{Hg})$ concentration mean \pm standard deviation in embryo and a) mother weight (g) and, b) embryo weight (g) in rig shark caught in Porirua Harbour.

Figure 33: Relationship between Embryo Zinc ( $\mathrm{Zn}$ ) concentration and mother liver $\mathrm{Hg}$ concentrations mean \pm standard deviation. 


\section{List of Tables}

Table 1: Table of worldwide regulations for acceptable edible concentrations of copper $(\mathrm{Cu})$, zinc $(\mathrm{Zn})$, lead $(\mathrm{Pb})$ and mercury $(\mathrm{Hg})$ in edible fish tissue $\mathrm{mg} / \mathrm{kg} \mathrm{w.w.}$

Table 2: Summary of metal concentration in sediments from five sites sampled in Porirua Harbour (PAH - Pauatahanui, POR- Onepoto, locations shown in Figure 5) in November/December 2015. Sediment guidelines are ANZECC (2000) and Auckland Regional Council Environmental Response Criteria (ARC ERC 2004), measured in mg/kg d.w, retrieved from Oliver (2016).

Table 3: Macroscopic maturity stages to evaluate sexual maturity of male rig shark, adapted from Frisk (2009).

Table 4: Macroscopic maturity stages to evaluate female elasmobranch sexual maturity, adapted from Frisk (2009).

Table 5: Macroscopic maturity stages to evaluate sexual maturity of flatfish, adapted from Stevens et al. (2010).

Table 6: Detection Limit for the metals $\mathrm{Cu}, \mathrm{Zn}, \mathrm{Pb}$ and $\mathrm{Hg}$ in Inductively Coupled Plasma Mass Spectrometer (ICPMS).

Table 7: Percentage frequency (\%F) of prey items in the stomachs of flatfish (yellow belly flounder and sand flounder), speckled sole and adult rig shark collected from Porirua Harbour in 2018, excluding individuals that were tagged/released.

Table 8. Mean concentrations ( $\mathrm{mg} / \mathrm{kg} \mathrm{w} . \mathrm{w}$ ) of metals \pm standard error in the tissue of flatfish (yellow belly flounder and sand flounder), rig shark and rays (short tailed stingray and eagle ray) caught in Porirua Harbour in 2018.

Table 9: linear model results for heavy metals $(\mathrm{Cu}, \mathrm{Zn}, \mathrm{Pb}, \mathrm{Hg})$ in flatfish tissue (muscle and liver) with Total Length $(\mathrm{cm})$ and weight $(\mathrm{g})$ as the covariate. Statistically significant results $\mathrm{p}=<0.05$ indicated by*....

Table 10: Linear model results for heavy metals $(\mathrm{Cu}, \mathrm{Zn}, \mathrm{Pb}, \mathrm{Hg}$ ) in rig shark tissue (muscle and liver) with Total Length $(\mathrm{cm})$ and weight $(\mathrm{g})$ as the covariate. Statistically significant results $p=<0.05$ indicated by*

Table 11: Table showing mean Pb concentrations $(\mathrm{mg} / \mathrm{kg} \mathrm{w} . \mathrm{w}) \pm$ standard deviation in tissue (muscle and liver) of rig shark caught in Porirua Harbour in 2018.

Table 12: Mean concentrations of heavy metals $(\mathrm{Cu}, \mathrm{Zn}, \mathrm{Pb}, \mathrm{Hg})(\mathrm{mg} / \mathrm{kg} \mathrm{w} . \mathrm{w}) \pm$ standard deviations in the tissue (muscle and liver) of rig shark, yellow belly flounder, sand flounder, speckled sole, eagle ray and short tailed stingray caught in Porirua Harbour in 2018.

Table 13: Mean heavy metal concentrations ( $\mathrm{Cu}, \mathrm{Zn}, \mathrm{Pb}, \mathrm{Hg})(\mathrm{mg} / \mathrm{kg}$ d.w) \pm standard deviations, and the range found in the tissue (muscle and liver) of adult rig shark and the tissue (muscle) of their near-term embryos.

Table 14: Linear model results showing relationship between embryo (muscle) heavy metal concentration ( $\mathrm{Cu}, \mathrm{Zn}, \mathrm{Pb}, \mathrm{Hg}$ ) and mother tissue (liver and muscle) concentrations, embryo and mother weight $(\mathrm{g})$, embryo and mother Total Length $(\mathrm{cm})$. Results shown in $\mathrm{mg} / \mathrm{kg} \mathrm{d} . \mathrm{w}$. Statistically significant results $p=<0.05$ indicated by* 


\section{Abstract}

Heavy metal or metalloids are common pollutants that are discharged into the aquatic environment by a variety of natural and anthropogenic sources, and have the ability to bioaccumulate in the tissues of marine organisms. Fish are among the top consumers in aquatic ecosystems and are widely recognised as bio-indicators for heavy metal pollution. Accumulation of heavy metals is influenced by factors such as species, age, size, and trophic level and can be found in various tissue types, such as muscle and liver tissue. In addition, contaminated fish can pose a threat to human consumers as they can cause acute and chronic disorders.

Estuaries are particularly vulnerable to heavy metal pollution as they are as they are a direct recipient of raw sewage, industrial, residential and farming runoff. Estuaries provide essential habitat for a range of species, including fishes that occupy estuaries permanently or seasonally for breeding. Te Awarua-o-Porirua Harbour (Porirua Harbour) is the largest, and the most significant estuary in the southern North Island of New Zealand. It is a 807 hectare tidal lagoon estuary next to Porirua City and consists of two distinct estuary arms, Onepoto and Pauatahanui. Porirua Harbour once boasted a healthy and diverse ecosystem that supported fishes that are prized by the Ngati Toa as kaimoana. However, heavy metal contamination has become problematic following the introduction of intensive industry and development in the harbour catchment.

The aim of this research was to 1 ) quantify levels of four heavy metals ( $\mathrm{Cu}, \mathrm{Zn}, \mathrm{Pb}$, and $\mathrm{Hg}$ ) in the tissue (muscle and liver) of yellow belly flounder (Pātiki, tōtara, Rhombosolea leporina), sand flounder (Pātiki, Rhombosolea plebeia), speckled sole (Peltorhamphus latus), rig shark (Pioke, Makō, Mangō, Mustelus lenticulatus), short-tailed stingray (Whai, Dasyatis brevicaudata), and eagle ray (Whai keo, Myliobatis tenuicaudatus) caught in Porirua Harbour, and look for differences between sexes, tissue types, as well as effects of size and age, 2) examine each fish sampled for general metrics of health (parasite load, skin lesions, etc.) as well as diet, and look for relationships with body burdens of metals, 3) examine maternal offloading of heavy metals from pregnant rig shark to near-term embryos, 4) examine the movement of benthic fishes between the two estuary arms using mark/recapture methods. 
To assess heavy metal accumulation and movement in benthic fishes, fish were collected and/or tagged over a 4-month period in 2018 (March-August) across 8 sites in Porirua Harbour. Tagged fish were unable to be recovered so conclusions were left undetermined. Overall, liver tissue had the highest levels of heavy metal concentration, with the expectation of $\mathrm{Hg}$ being elevated in the muscle tissue of rig shark. There were significant differences observed for species, fish size, with smaller fishes having higher $\mathrm{Cu}$ concentration, and larger fish having higher $\mathrm{Hg}$ concentrations. There was little to no relationship observed between $\mathrm{Zn}$ and $\mathrm{Pb}$ concentrations in this study.

To investigate the role of maternal offloading of heavy metals from maternal rig shark to their near-term embryos, embryos were collected from the uterus of 13 pregnant females and assessed individually for heavy metal $(\mathrm{Cu}, \mathrm{Zn}, \mathrm{Pb}, \mathrm{Hg})$ concentrations in muscle tissue. Overall, there was no relationship for $\mathrm{Cu}$ between the amount in embryos and either the maternal concentration or size. However, $\mathrm{Zn}$ and $\mathrm{Pb}$ concentration in rig shark embryos were positively related with maternal size. Therefore, size explained embryo $\mathrm{Zn}$ and $\mathrm{Pb}$ concentration in rig shark embryos, and embryo $\mathrm{Hg}$ concentrations were explained by maternal concentrations and size, suggesting maternal offloading of $\mathrm{Hg}$ might be occurring in rig shark.

The results of this thesis support prior research findings of heavy metal accumulation depending primarily on the tissue type, fish size and is metal and species specific. This research adds to the currently lacking information on heavy metal accumulation in these study species, and will aid the ongoing monitoring of Porirua Harbour by Greater Wellington Regional Council and Porirua City Council. 


\section{Chapter 1: Literature review on heavy metal accumulation in marine fishes}

\section{Introduction}

The contamination of marine ecosystems with organic and inorganic pollutants has increased over the last few decades (Vinodhini et al. 2008). Heavy metal or metalloids are common pollutants that are discharged into the aquatic environment by a variety of natural and anthropogenic sources (Authman et al. 2015). Heavy metals are characterized by a long persistence in water and sediment, high toxicity, bioaccumulation and bio-magnification in the food web (Clearwater \& Meyer 2007). Therefore, when metals occur at high concentrations, they have the potential to cause devastating effects on the recipient environment and organisms (Vinodhini et al. 2008; Authman et al. 2015).

Fish are among the top consumers in aquatic ecosystems and occupy high trophic levels (Vinodhini et al. 2008). Due to this, fish are widely recognized as bio-indicators for a range of pollutants including heavy metals (Macdonald et al. 1997). Fish can be exposed to metals through contact with water, sediment, diet and they can accumulate in a range of different tissues such as liver, gill, muscle, kidney, and gonads (Miziray \& Kiminer 2016). Metal accumulation in fish can disrupt physiological activities, biochemical parameters and can result in morphological deformities and even death (Authman et al. 2015). In addition, contaminated fish can pose a threat to human consumers as they can cause acute and chronic disorders (El-Moselhy et al. 2014).

\section{Essential and non-essential metals}

'Essential metals' are naturally occurring elements such as Copper ( $\mathrm{Cu}$ ), Chromium (Cr), Zinc (Zn) and Selenium (Se) and are crucial for various physiological and biochemical functions (Authman et al. 2015). Copper (Cu) provides a role in cellular metabolism but can become toxic to intercellular mechanisms at high levels (Begum et al. 2006). Although it is naturally abundant in the environment, excess $\mathrm{Cu}$ is released through insecticides, fungicides, and 
discharge of wastewaters (Begum et al. 2006). Chromium (Cr) is an essential metal necessary for the metabolism of carbohydrates but enters the aquatic food chain through dyeing, printing and pharmaceutical industries (Authman et al. 2015). Selenium (Se) is required for growth and thyroid hormone metabolism but enters waterways through sewage sludge, oil refineries and coal-fired power plants (Muscatello \& Janz 2009). Iron (Fe) is a predominant component of mining effluent that is untreated and discharged into aquatic environments and can persist in sediments for long periods, but is an essential component to blood pigment in some organisms (Bruening et al. 1985; Barjhoux et al. 2012). Zinc (Zn) is involved in nucleic acid synthesis, cell signalling and neurotransmission (Zaki et al. 2010). The common sources of anthropogenic $\mathrm{Zn}$ are from plumbing gear and galvanized ironwork leaching into waterways (Authman et al. 2015).

'Non-essential metals' occur naturally in addition to entering the environment through anthropogenic sources and provide no biological function (Yilmaz et al. 2010; Authman et al. 2015). Lead $(\mathrm{Pb})$ is a persistent metalloid which has increased in concentration due to mining, leaded gasoline, battery manufacturing and paints (Farell et al. 2012; Sfakianakis et al. 2015). $\mathrm{Pb}$ enters the aquatic environment through industrial and smelter discharges (Farell et al. 2012). Cadmium (Cd) tends to accumulate in marine habitats due to the increase in battery production over the 20th century (Nayak et al. 2007). Arguably the most significant and documented heavy metal is mercury $(\mathrm{Hg})$ (Bosch et al. 2016). $\mathrm{Hg}$ enters the environment naturally from volcanic events and forest fires but is also used in the production of paint and electrical equipment (Authman et al. 2015; Bosch et al. 2016). It is estimated that two-thirds of $\mathrm{Hg}$ present in the aquatic environment is from an anthropogenic origin, primarily from the burning of fossil fuels (Morel et al. 1998; Boeing et al. 2000; Bosch et al. 2016). Hg is released in its inorganic form but is converted through microbial activity to its organic methylmercury form in which it is bio-accumulated (Lyos et al. 2017).

The presence of heavy metals in various environmental matrices has led to them being considered 'trace elements' with their bioavailability to organisms influenced by factors such as species, physiology, age and trophic level (Dural et al. 2007). Bioavailability is also affected by temperature and by chemical factors such as lipid solubility, $\mathrm{pH}$, salinity and dissolved carbon in the environment (Kalman et al. 2014). 


\section{Uptake routes}

Fish can uptake metals directly from the surrounding water and sediment, or indirectly through diet (Miziray \& Kiminer 2016). After absorption, metals are transported through the bloodstream to tissues in which they are accumulated (Authman et al. 2015). Dietary uptake is one of the primary mechanisms for accumulation of pollutants (Clearwater \& Meyer 2002). In fish, heavy metal absorption commonly occurs in the alkaline environment of the intestines but is dependent on the trophic level at which fish feed (Clearwater \& Meyer 2002). This is because the length of the digestive tract is extremely variable, with herbivores characterized by a long intestinal tract and some predatory fish completely lack a formal stomach (Clearwater \& Meyer 2002; Mathews \& Fisher 2009). Due to this, dietary uptake is greatly species-specific, and accurate results can only be obtained through laboratory experiments where contaminated foods are fed to a recipient, and the rate of accumulation is monitored (Andrews et al. 2000; Mathews \& Fisher 2009; Authman et al. 2015).

Aqueous uptake occurs through the skin and gills and accumulation in these tissues can act as a 'snapshot' of current pollution status in the environment (Mathews \& Fisher 2009). Aqueous uptake can be influenced by the availability of waterborne metals and the size of the available surface area for accumulation (Zang et al. 2011). A high affinity for waterborne metals has been observed in the placoid scales of spiny dogfish (Squalus acanthias) and demersal \& benthic fish due to continuous contact with contaminated sediments (Fakaner et al. 1983; Mathews \& Fisher 2009; Zang et al. 2011).

The relative importance of different uptake routes in fish is debated (Kalman et al. 2014). Studies claim $70-90 \%$ of $\mathrm{Zn}$ uptake in marine teleosts is through diet whereas others report $\mathrm{Zn}$ as being a waterborne metal that shows high affinity for gill and skin tissue through aqueous exposure (Celik et al. 2004; Mathews \& Fisher 2009; Moselhy et al. 2014). A method gaining popularity is 'biokinetics' where the assimilation efficiency (AE) of heavy metals can be applied to differentiate the two uptake routes (Pichkard et al. 2006; Kalman et al. 2014). It is suggested that the uptake of metals is dependent on trophic status, with predatory fishes having a higher AE due to the higher enzymatic activity associated with the breakdown of complex multicellular prey (Pouli et al. 2017). This method discredits one route as being more 
important than the other as they both occur simultaneously in the natural environment (Kalman et al. 2014).

\section{Metal distribution across tissues}

Metal distribution in different tissue types is dependent on fish traits such as size, weight, physiology, diet, age, and sex (Mathews \& Fisher 2009). Metals can be found in various tissues, including gills, liver, muscle, brain, gonads, intestines and bone (Kaly \& Canil 1999; Kalman et al. 2014). In addition, immature fish show higher accumulation rates than adults due to a difference in metabolic demand, whereas sexually mature fish typically distribute excess metals to reproductive organs (Kaly \& Canil 1999). Literature tends to focus on gill, liver and muscle tissue as they are thought to be the best bio-indicators for metal pollution in freshwater and marine ecosystems (Kalman et al. 2014).

Gill

Metal distribution in gill tissue can result in deleterious morphological and physiological effects on fish collected from contaminated field sites (Dural et al. 2007; Abalaka 2015). Metal accumulation can cause visible gill damage, such as lesions and an increase in opercula (respiratory) activity (Pieterse 2004). The large surface area of gills allows rapid uptake of waterborne metals such as $\mathrm{Cu}$ and $\mathrm{Zn}$ with stimulation in mucus secretion from the gills characteristic symptoms (Celik et al. 2004; Monterio et al. 2009; Authman et al. 2015). Research in the Mediterranean has shown high toxicity of $\mathrm{Cu}$ and $\mathrm{Zn}$, and gill conditions in mackerel (Trachurus mediterraneus), and grey mullet (Mugil cephalus) were correlated with areas of high aqueous pollution (Canli \& Arli 2003; Makedonski et al. 2017).

Heavy metal accumulation in gill epithelia results in a negative charge on the metal attraction sites (Barjhoux 2001). Nieboer and Richardson (1980) state that the relative binding efficiency of metals is due to metal electronegativity and the ability to form ionic and covalent bonds. This concept has since been applied to marine fish where gill epithelia are characterized by ligands that favour ionic bonding with $\mathrm{Cu}$ and Fe (Barjhoux 2001). Soluble ferrous iron (Fe2+) has been observed oxidizing to insoluble ferric compounds which then saturate gill lamellae and prevent respiration in Japanese rice fish (Oryzias latipes) (Chen et al. 2012). Laboratory 
studies have shown Cu toxicity induces a situation known as 'oxidative stress' in the gill tissue where an increase in reactive oxygen species (ROS) production leads to a dysfunction in lipids, proteins, and DNA (Sanchez et al. 2005; Hou et al. 2011). Winter flounder (Pseudopleuronectes americanus) exposed to waterborne $\mathrm{Cu}$ revealed $\mathrm{Na}$, K-ATPase activity increased, and accumulation in gill occurred at rates higher than other tissue (Bury \& Clover 2003). Zn toxicity can disrupt Ca2+ uptake in the gills, and this can lead to a blood condition known as hypocalcemia which has been observed in exposure periods from 48 hours to 32 days (Dang \& Wang 2009; Hassaninezhad et al. 2014; Vindhini \& Narayanan 2015).

In the field, accumulation in gill tissue is commonly used as a seasonal indicator where metal bioavailability fluctuates between wet and dry seasons (Sahal et al. 2016; D'costa et al. 2017). The proliferation of waterborne metals in wet seasons is due to an increase in industrial and agricultural runoff and has been observed in the Mediterranean (Dural et al. 2007), India (Arulkumar et al. 2017), and the Middle East (Khoshnamvand 2012).

\section{Liver}

Rapid accumulation and distribution of metals in liver tissue are related to the general function of the liver as a detoxifier (Vindhini \& Narayanan 2015). Recently, Omar et al. (2014) concluded that liver tissue is the target organ for Se and $\mathrm{Cu}$ due to their biological role in metabolism. This is complemented by other research where Se and $\mathrm{Cu}$ accumulate at higher concentrations in the liver than other tissues and show a positive correlation with age and size (Castro-González et al. 2008; Elnabris et al. 2013; Pouli et al. 2017). For most fish, the range for Se toxicity is $0.25-0.70 \mu \mathrm{g} / \mathrm{g}$ diet, but liver accumulation as low as $3 \mu \mathrm{g} / \mathrm{g}$ diet can be toxic (Mziray et al. 2006; Muscatello et al. 2009).

Positive correlations with age and size have been observed with non-essential metals (Dallinger et al. 1987; Zauke et al. 1999; Miziray \& Kiminer, 2016). In the Mediterranean, Pb concentration in the liver increased with the size of king mackerel (Scomberomorus cavalla) and swordfish (Xiphias gladius) (Canli \& Atli, 2003; Moselhy et al. 2014). In addition, the liver is the only organ equipped to demethylate and detoxify mercury in fish (Lyons et al. 2017). 
This is achieved by the liver conjugating $\mathrm{Hg}$ crystals to Se and other proteins and peptides so they can be excreted (Lyons et al. 2017).

Laboratory experiments have shown that even at low environmental concentrations, accumulation of $\mathrm{Cu}$ can show in liver tissue within 48 hours (Clearwater \& Meyer 2002; Authum et al. 2015). At sub-lethal concentrations, visible external lesions and necrosis on the liver of the common goby (Pomatoschistus microps) have been documented at levels of 0.8 $\mu \mathrm{M} / \mathrm{L} \mathrm{Cu}$ (Vieira et al. 2009). This is consistent with earlier research, where damage and shrinkage were observed in the liver of the Senegales sole (Solea senegalensis) at concentrations of 0.8-100 $\mu \mathrm{M} / \mathrm{L} \mathrm{Cu}$ (Arellano et al. 1999).

\section{Muscle}

Muscle tissue is not an active site for metal biotransformation and accumulation (Uysal et al. 2008), therefore distribution rates are relatively low (Uysal et al. 2008). However, there is evidence for significant variability in concentrations of metals in muscle among marine fish (Uysal et al. 2008; Elnabris et al. 2013; Miziray \& Kiminer 2016).

Muscle tissue is the most commonly eaten part of fish, and there is a significant focus on bioaccumulation research due to human consumption risk (Uysal et al. 2008). Global fish supply has doubled since 2000 and averaged at over 90.4 million tonnes in 2012 (Tacon \& Metian 2015; Pauly \& Zeller 2016). Adverse health effects of consuming heavy metals, particularly non-essentials, have been apparent for some time, and include cardiovascular diseases, liver damage, renal failure, and death (El-Moselhy et al. 2014). Due to this, international monitoring programs have been implemented to assess fish quality and environmental health (El-Moselhy et al. 2014; Miziray \& Kiminer 2016). International legislation, such as The U.S. Environmental Protection Agency (USEPA), Food and Agriculture Organization of the United Nations (FAO), European Food Safety Authority (AFSA) have proposed a criterion for maximum heavy metal levels in edible fish tissue (Authman et al. 2015) (Table 1). At trace amounts, essential metals are crucial to human diet as they benefit immunity and help maintain cellular function (Nriagu 2007). In addition, fish and seafood provide essential nutritional components such as polyunsaturated omega- 3 fatty acids and 
various vitamins and minerals (Bosch 2016). Estimated daily intake (EDI) and Provisional tolerable daily intake (PTDI) values for $60 \mathrm{~kg}$ body weight have been developed for essential metals that allow human consumers to get the nutritional benefit of eating fish but avoiding harmful effects (Rahman et al. 2012). However, there is no consistent international guidance for all metal residues in aquatic ecosystems and fish tissue (Table 1) (Yilmaz. 2009; Dang et al. 2009; Yilmaz. 2009; Elnabris et al. 2013; Arulkamar et al. 2017).

Table 1: Table of worldwide regulations for acceptable edible concentrations of copper $(\mathrm{Cu})$, zinc $(\mathrm{Zn})$, lead $(\mathrm{Pb})$ and mercury $(\mathrm{Hg})$ in edible fish tissue $\mathrm{mg} / \mathrm{kg}$ w.w.

\begin{tabular}{|c|c|c|c|c|c|c|}
\hline Metal & $\begin{array}{l}\text { Estimated daily } \\
\text { intake (EDI) } \\
\text { Mg/day/person }\end{array}$ & $\begin{array}{l}\text { Provisional } \\
\text { tolerable } \\
\text { daily intake } \\
\text { (PTDI) 60kg } \\
\text { body weight }\end{array}$ & $\begin{array}{l}\text { Maximum } \\
\text { Allowable } \\
\text { Limit (MAL) } \\
\text { (mg/kg) }\end{array}$ & $\begin{array}{l}\text { Regulatory } \\
\text { body }\end{array}$ & Specifications & $\begin{array}{l}\text { Regulatory } \\
\text { Reference }\end{array}$ \\
\hline \multirow[t]{3}{*}{$\begin{array}{l}\text { Copper } \\
\text { (Cu) }\end{array}$} & & & 30 & $\begin{array}{l}\text { United } \\
\text { Nations }\end{array}$ & $\begin{array}{l}\text { Uncanned meat } \\
\text { products }\end{array}$ & Nauen (1983) \\
\hline & 0.0998 & $3-30$ & 20 & $\begin{array}{l}\text { Bangladesh } \\
\text { Turkey }\end{array}$ & & $\begin{array}{l}\text { Rahman et al. } \\
\text { (2012) } \\
\text { Yilmaz (2009) }\end{array}$ \\
\hline & & & 30 & $\begin{array}{l}\text { European } \\
\text { Union }\end{array}$ & & $\begin{array}{l}\text { Eu limits } \\
\text { JECFA (2003) } \\
\text { FAO (2003) }\end{array}$ \\
\hline \multirow[t]{3}{*}{ Zinc (Zn) } & & & 30 & $\begin{array}{l}\text { United } \\
\text { Nations }\end{array}$ & & Nauen (1983) \\
\hline & 0.7392 & $18-60$ & 50 & Bangladesh & & $\begin{array}{l}\text { Rahman et al. } \\
(2012)\end{array}$ \\
\hline & & & 50 & Turkey & & Yilmaz (2009) \\
\hline \multirow[t]{2}{*}{$\begin{array}{l}\text { Mercury } \\
\text { (Hg) }\end{array}$} & & & 1 & $\begin{array}{l}\text { European } \\
\text { Union }\end{array}$ & $\begin{array}{l}\text { Predatory fish and } \\
\text { sharks }\end{array}$ & FAO (2003) \\
\hline & & & 0.5 & $\begin{array}{l}\text { European } \\
\text { Union } \\
\text { New Zealand } \\
\text { Australia }\end{array}$ & All fish & $\begin{array}{l}\text { FAO (2003) } \\
\text { FSANZ (2015) }\end{array}$ \\
\hline \multirow[t]{6}{*}{ Lead (Pb) } & & & 0.5 & $\begin{array}{l}\text { South Africa } \\
\text { New Zealand } \\
\text { Australia }\end{array}$ & Fish product & $\begin{array}{l}\text { DOH (2004) } \\
\text { FSANZ (2015) }\end{array}$ \\
\hline & & & 0.2 & $\begin{array}{l}\text { European } \\
\text { Union } \\
\text { New Zealand } \\
\text { Australia }\end{array}$ & Fish product & $\begin{array}{l}\text { FAO (2003) } \\
\text { FSANZ (2015) }\end{array}$ \\
\hline & & & 0.4 & $\begin{array}{l}\text { United } \\
\text { Nations }\end{array}$ & $\begin{array}{l}\text { Wedge sole } \\
\text { (Dicologoglassa } \\
\text { cuneata) }\end{array}$ & FAO (2003) \\
\hline & & & 0.3 & $\begin{array}{l}\text { United } \\
\text { Nations }\end{array}$ & Fish muscle tissue & $\begin{array}{l}\text { Commission } \\
\text { regulation (EC) } \\
1881 / 2006\end{array}$ \\
\hline & & & 1 & Turkey & & Yilmaz (2009) \\
\hline & 0.0203 & & & Bangladesh & & $\begin{array}{l}\text { Rahman et al. } \\
\text { (2012) }\end{array}$ \\
\hline
\end{tabular}




\section{Heavy metal interactions}

Natural systems are typically contaminated with a mixture of heavy metals and accumulation of particular heavy metals can be altered by the presence of others (Pelgrom et al. 1995; Jezierska \& Witeska 2006; Akoto et al. 2014). It has been long established that synergistic, additive and antagonist effects can occur in fishes (Jezierska \& Witeska 2001). Heavy metals can compete for binding sites, or the metals can influence one another (Bosch et al. 2016).

Kojadinovic et al. (2007) found heavy metal detoxification processes depend on the interaction between multiple metals. The formation of non-toxic insoluble minerals after the demethylation of $\mathrm{Hg}$ by Se has been observed in a range of taxa from marine mammals to sea birds (Martoja 1980; Kargin \& Çoğun 1999; Ikemoto et al. 2004). However, the interaction between Se and $\mathrm{Hg}$ in fishes is the most extensity reviewed (Klaverkamp et al. 1983; Pelletier 1986; Kaneko \& Ralston 2007; Peterson et al. 2007). Positive correlations exist between Se and $\mathrm{Hg}$ in the muscle and liver of fish (Ribeyre et al. 1995; Branco et al. 2007; Bosch et al. 2016). Kojadinovic et al. (2007) found a positive correlation between Se and $\mathrm{Hg}$ in the liver of predatory fish which provided an argument for Se mediated $\mathrm{Hg}$ detoxification in higher trophic levels.

Interactions between heavy metals being examined only at an organ level may ignore interactions occurring on the whole-organism level (Ribeyre et al. 1995). It is well established that the levels of heavy metal in fish is highly variable, depending on the organs studied (Ribeyre et al. 1995). Similarly, the toxic effects of heavy metals rely not only on the metal itself but on the organism tested. $\mathrm{Cd}$ and $\mathrm{Zn}$ have antagonistic effects on the Nile Tilapia ( $T$. niloticia) (Kargin \& Çoğun 1999) and in the sand fiddler crab (Uca pugilator) (Weis 1980), while it has synergistic effects in some copepod species (Verriopoulos \& Dimas 1988). Bosch et al. (2016) claim that the measurement of one metal indicates the other corresponding metal, but interpreting relationships should be done with caution.

\section{Metallothionein Protein}

Metallothioneins are cysteine-rich proteins that bind with high affinity to heavy metals such as $\mathrm{Cu}, \mathrm{Zn}, \mathrm{Hg}$, and $\mathrm{Cd}$, and are used as indicators of heavy metal pollution in fishes (George \& 
Olsson 1994; Wong et al. 2001). Binding metals to metallothioneins is the most common detoxification strategy in marine organisms and a good indicator of overall heavy metal burden (Kojadinovic et al. 2007). This is because biosynthesis is induced after exposure to heavy metals, so levels of metallothioneins are positively correlated with the presence of metal concentrations, and the presence of metallothionein proteins have been found in liver, kidney, gill, and muscle (Liu et al. 1996). For example, a majority of Cd found in intestine and gill tissue of marine fish is bound to metallothionein (Wong et al. 2001).

\section{Excretion}

The rate at which heavy metals are excreted from fish is poorly understood (Clearwater \& Meyer 2002). However, there is a general consensus that females show a lower metal burden compared to males due to oocyte and gamete production (Barbra et al. 2009; Mathews \& Fisher. 2009). Such findings have been documented in marine and freshwater fish from Europe and Asia (Canli \& Atil 2003; Li et al. 2017).

Up-regulating mucus secretion from skin cells has also been documented in marine taxa as an attempt to excrete excess metals (Grosell et al. 2002). Excess Cu stimulates a high turnover of cells in the digestive tract and is expelled through bile (Clearwater \& Meyer 2002). Likewise, salmon have been observed up-regulating fecal excretion due to excess $\mathrm{Cu}$, and winter flounder ( $P$. americanus) store excess $\mathrm{Zn}$ in the metal-binding proteins metallothionein until the intestinal tract Is sloughed (Bremner 1991; Bury et al. 1998; Bury \& Clover 2003).

The rate of excretion differs across organs, with liver typically exhibiting higher levels of detoxification following laboratory depuration experiments (Bury \& Clover 2003). Senegalese sole (S. senegalensis) subject to Cu exposure (100 $\mathrm{gg}$ Cu SO4/L) for seven days, followed by four days depuration, revealed a fast decrease in the liver concentration compared to other tissues (Arellano et al. 1999). However, such results should be interpreted with caution, as Cu naturally leads to the synthesis of metal-binding proteins, which stimulates detoxification in any living organism (Bremmer 1991). Concerns have been raised over the credibility of testing excretion mechanisms in the field where they cannot be controlled (Bury \& Clover 2003). Canli \& Atli (2003) examined heavy metal excretion in pelagic fishes in the Mediterranean, and 
although they found high excretion rates of Fe in older and larger fish, they acknowledged the difficulty in attributing this to regulation or other environmental factors.

\section{Maternal offloading}

Although heavy metal accumulation is known to occur through diet and exposure to contaminated water or sediment, little is known about the accumulation of contaminants in offspring before hatching or birth (Lyons \& Lowe 2013a). Maternal 'offloading' or 'transfer' is the process in which females transfer contaminants to their offspring during the reproductive process (Lyons \& Lowe 2013a; Naidoo et al. 2017). This phenomenon has been documented in a range of taxa from mammals (Borell et al. 1995), turtles (Guirlet et al. 2008) and birds (Van den Steen et al. 2009). The most extensive review on maternal offloading in the marine environment is the transfer of contaminants via lactation of lipid-rich milk in marine mammals (Addison \& Brodie 1977; Borell et al. 1995; Mongillo et al. 2012). Due to this, females typically have a lower contaminant burden compared to males (Borell et al. 1995).

Maternal offloading of heavy metals has been recognised in a range of elasmobranch species (Lyons \& Lowe 2013a; Naidoo et al. 2017). In elasmobranchs, offloading of $\mathrm{Hg}$ is the most documented (Lyons \& Lowe 2013a; Naidoo et al. 2017). However, the process is complicated due to Hg's inorganic and organic (methylmercury) forms having affinity for multiple tissue types (Demski \& Wourms 2013), and lengthy gestation periods which can range from months to over a year (van Hees et al. 2017). During gestation, viviparous elasmobranchs invest large amounts of energy into the production of live young (Demski \& Wourms 2013). Most of this energy is derived from lipid-dense livers which are a known site of accumulation for contaminants (Hamlett 2005; Omar et al. 2014). Other mechanisms behind the transfer of resources to young occur through histotroph or uterine milk, and oophagy where embryos feed on eggs in the uteri (Hamlett 2005). However, the mechanisms behind maternal offloading in elasmobranchs are poorly understood, and the transfer of other essential and non-essential metals has not been extensively reviewed. 


\section{Ecosystem Implications}

Acute effects of heavy metals in freshwater fish have been observed for decades in laboratory and field studies (Pascoe et al. 1986; Khangarot \& Ray 1987; Authman et al. 2015), but less work has been done on marine fish. Dietary exposure of excess $\mathrm{Cu}$ reduced the growth, decreased immune response and changed the behaviour of tilapia, caused spinal and cardiovascular deformities in Japanese medaka, and decreased sperm quality in rainbow trout (Oncorhynchus mykiss) (Gainey \& Kenyon 1990; Barjhoux et al. 2012; Authman et al. 2015). Similarly, catfish exposed to 5ppm of $\mathrm{Pb}$ for 150 days revealed reduced gonad growth and a decrease in lipid and cholesterol levels in the brain (Castro-González et al. 2008).

Research has focused heavily on embryonic and larval stages due to the simplicity in manipulation and handling, and because early life stages are typically more vulnerable to environmental stress (Witeska et al. 1995; Kennedy 2011). Larvae usually show spinal deformities, reduced locomotion and increased susceptibility to infections under heavy metal exposure, as has been seen in the catadromous Chinese sturgeon (Acipenser sinensis) (Martinez et al. 2002; Hou et al. 2011). Excess heavy metals have been documented ex-situ precipitating on the surface of fish eggs and suffocating them (Authman et al. 2015). Field observations have been limited, but some studies have revealed deformities in swim bladders and lateral lines, cataracts and skin lesions in contaminated fish (Kennedy 2011).

Larval deformities are recognized as biometrics of environmental stress, but there is little acknowledgment of broader implications to the environment (Barbara et al. 2009). Despite this, it is agreed that metal toxicity in embryonic and larval stages can have broader consequences by causing a reduction in growth, survival and reproductive effort, and thereby potentially affecting population dynamics and future generations of fish (Barbara et al. 2009). Pouli et al. (2017) addressed the lack of current research on marine fish and attributed it to the simplicity of freshwater ex-situ experiments. The literature available on marine fishes are restricted to euryhaline/brackish fish and catadromous fish that spawn in salt water (Hou et al. 2011; McKinley et al. 2011; Guo et al. 2016). To date, there appears to be no thorough exsitu study of heavy metal toxicity on a marine fish, especially in adult form (Guo et al. 2016). Translating results from freshwater ecosystems should be treated with caution as salt water 
has different chemical and physical factors that influence metal bioavailability, uptake, distribution and excretion of metals (Varol et al. 2017).

\section{Conclusion}

The accumulation of heavy metals in marine fish has been extensively reviewed over the past few decades and corresponds with an increase in heavy metal pollution entering waterways. The use of fish as bio-indicators offers a wide range of biologically and ecologically relevant information in assessing heavy metal pollution and environmental health. Literature has revealed that the persistence, toxicity and rate at which metals are accumulating in fish is an ecological and human health concern in some regions. As previously discussed, heavy metal toxicity in marine fishes depends on the metal type, bioavailability, species, uptake-routes, metal distribution, excretion and rate of exposure (Mathews \& Fisher 2009). However, there are gaps in research regarding metal accumulation, excretion and ecological implications in marine fish. It is abundantly clear that metals can cause numerous toxic effects, disrupt physiological and biochemical activities and cause morphological deformities in both marine and freshwater fish. Research has revealed the complex nature of accumulation as it is influenced by biological factors such as size, age, trophic level and physical factors such as $\mathrm{pH}$, alkalinity and dissolved organic carbon. Metal pollution can bio-accumulate in fish, thereby potentially having deleterious effects on fish populations 


\section{Chapter 2: Heavy metal accumulation in marine fishes in Porirua Harbour}

\section{Introduction}

Estuaries are defined as a partially enclosed body of water where river and ocean meet and form brackish water (Sudsandee et al. 2017). Estuaries worldwide provide a crucial ecological function such as supplying nursery habitat for coastal fisheries species, habitat for birds, and shellfish production (Sheaves et al. 2015). It is estimated that $40 \%$ of the world population is living along coastlines and estuaries, which has accelerated estuary degradation due to many anthropogenic factors (Cloern et al. 2016). Because heavy metals have long persistence in sediment, estuary environments are particularly vulnerable as they are a direct recipient of raw sewage, industrial, residential and farming runoff (Clearwater \& Meyer 2007; Islam et al. 2015). Heavy metals are washed into storm water systems as well as streams and rivers where they subsequently flow into estuaries (Clearwater \& Meyer 2007). A range of factors, many unquantifiable, affect the distribution of heavy metals in estuarine water and sediment (Tomlinson et al. 1980). For example, sediment particle size can affect binding efficiency with finer sediments having a higher affinity for metal absorption (Tomlinson et al. 1980; Clearwater \& Meyer 2007). It has been documented that estuaries commonly have high loads of detritus, and higher levels of dissolved organic matter cause an increase adherence of $\mathrm{Zn}$ to estuarine sediment (Tomlinson et al. 1980). Additional estuarine characteristics such as salinity, $\mathrm{pH}$ and sediment redox (oxidation) potential all interact with metals and their binding efficiency, which add to the complexity of monitoring metal pollution in these ecosystems (Clearwater \& Meyer 2007).

New Zealand has more than 300 estuaries which provide significant ecological importance, especially regarding commercial fish production (Robertson et al. 2015). Some fish species reside in estuaries all year round, whereas others occupy estuaries only as juveniles or migrate in and out with seasons (Radford et al. 2012). "Biogenic" habitats produced by living organisms strongly influence the abundance of fish within and among estuaries, with seagrass meadows and mangrove forests providing protection and a food source for fish (Morrison \& Francis 2000). Within New Zealand, many freshwater fish such as Inanga (Galaxias maculatus) 
Banded kōkopu (Galaxias fasciatus) Giant kōkopu (Galaxias argenteus), and long fin eels (Anguilla dieffenbachii) require fresh and salt water during their life cycles and spend significant periods of time in estuaries (McDowall 1976; Morrison \& Francis 2000; August 2008). It is estimated that Kaipara Harbour provides an essential nursery for North Island west coast snapper (Pagrus auratus) and contributes 90\% to the population (Radford et al. 2012). Moreover, larvae of the sand flounder (Rhombosolea plebeia) have been documented recruiting into Whangeteau Harbour (Roper 1986). However, New Zealand is not exempt from estuarine degradation experienced worldwide, and heavy metal pollution in sediments in Wellington Harbour (Stoffers et al. 1986), Manakau and Waitemata Harbour (Glasby et al. 1988), and Porirua Harbour (Glasby 1990) have been extensively studied since the 1980s.

\section{Porirua Harbour}

Te Awarua-o-Porirua Harbour (Porirua Harbour) is the largest, and the most significant estuary in the southern North Island of New Zealand (Francis 2013; Oliver \& Milne 2016; Figure 1). It is an 807 hectare tidal lagoon estuary next to the city of Porirua and consists of two distinct estuary arms, Pauatahanui (524 hectares) and Onepoto (283 hectares) (Francis 2012a; Figure 1). Porirua Harbour once boasted a healthy and diverse ecosystem that supported fish and shellfish that are prized by the Ngati Toa as kaimoana (Francis 2012a). However, the physical nature and ecology of the harbour changed following the introduction of intensive industry and development in the harbour catchment (Francis 2013). Heavy metals are problematic in the harbour as only $35 \%$ of the water is emptied at low tide, so there is a high level of retention within the ecosystem (Francis 2013).

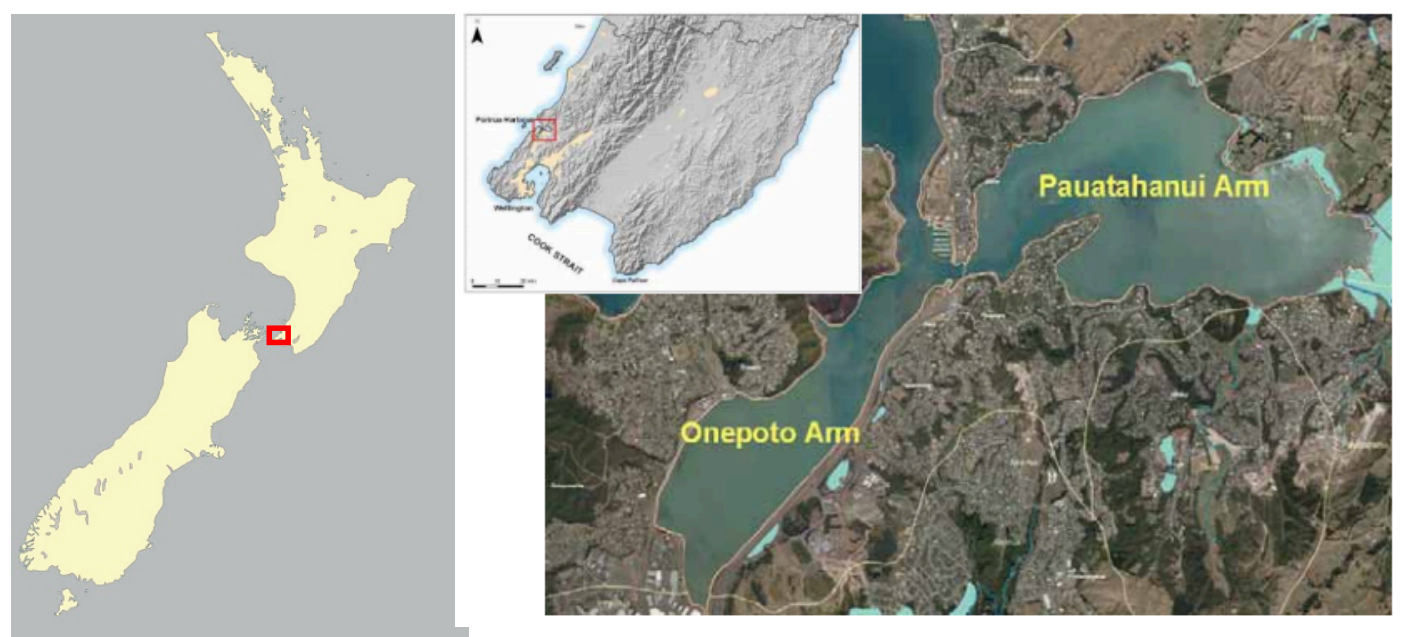

Figure 1: Arial photograph of Porirua Harbour located in the North Island of New Zealand, and the two estuary arms, Onepoto and Pauatahanui, sourced from Green, Stevens \& Oliver (2014). 


\section{Heavy metals in Porirua Harbour}

Data on heavy metal concentration in Porirua Harbour sediment are available from five subtidal surveys (2004, 2005, 2008, 2010 and 2015/2016) undertaken by the Greater Wellington Regional Council (Oliver \& Milne 2016). Both New Zealand and Australian Environment and Conservation Council (ANZECC 2000) and the Auckland Regional Council's (2004) Amber and Red 'Environmental Response Criteria' (ERC) sediment quality guidelines are used to assess heavy metals in Porirua Harbours sediments (ANZECC 2000; ARC 2004; Oliver 2014) (Table 2).

- The 'low' values (ANZECC ISQG-Low) state the onset of biological effects of the contaminants could occur and provide an 'early warning' for management (ANZECC 2000).

- The 'high' values (ANZECC ISQG-High) state significant biological effects are expected (ANZECC 2000).

Table 2: Summary of metal concentration in sediments from five sites sampled in Porirua Harbour (PAH - Pauatahanui, POR- Onepoto, locations shown in Figure 5) in November/December 2015. Sediment guidelines are ANZECC (2000) and Auckland Regional Council Environmental Response Criteria (ARC ERC 2004), measured in mg/kg d.w, retrieved from Oliver (2016).

\begin{tabular}{|c|c|c|c|c|c|c|c|c|c|}
\hline & ANZECC & & ARC ERC & & PAH1 & PAH2 & РAH3 & POR1 & PORI2 \\
\hline $\begin{array}{l}\text { Metal } \\
\mathrm{mg} / \mathrm{kg}\end{array}$ & ISQG-low & ISQ-high & Amber & red & Mean & Mean & Mean & Mean & Mean \\
\hline $\mathrm{Cu}$ & 65 & 270 & 19 & 34 & 11.0 & 9.5 & 8.0 & 20.5 & 18.2 \\
\hline $\mathrm{Zn}$ & 200 & 410 & 124 & 150 & 73 & 63 & 62 & 179 & 139 \\
\hline $\mathrm{Hg}$ & 0.15 & 1 & & & 0.109 & 0.077 & 0.063 & 0.122 & 0.141 \\
\hline $\mathbf{P b}$ & 50 & 220 & 30 & 50 & 21 & 17.6 & 16.0 & 38 & 37.3 \\
\hline
\end{tabular}

Pauatahanui and Onepoto both consist of fine mud particles that provide a 'sink' for heavy metal contaminants, primarily those derived from contaminated storm-water discharge (Oliver \& Conwell 2014). In 2015, Cu and Pb in the Onepoto Arm exceeded the ARC (2004) ERC amber thresholds but were below ANZECC (2000) ISQG-Low trigger values (Oliver 2016). Zn concentrations at these sites exceeded the ERC red threshold, with the concentration at one Onepoto site nearly equal to the ANZECC (2000) ISQG-Low trigger value of $200 \mathrm{mg} / \mathrm{kg}$ in 2016 (Table 2). These results show a slight elevation in metal contamination from the $2008 / 2010$ survey findings and have been attributed to run off from the highway and railway network which runs adjacent to Onepoto (Oliver \& Conwell 2014; Oliver 2016). Metals in 2016 
were lower than 2010 and 2008 survey, but $\mathrm{Cu}, \mathrm{Pb}$, and $\mathrm{Zn}$ continued to exceed ARC ERC amber thresholds in all survey years (Oliver \& Conwell 2014; Oliver 2016). Hg has increased in concentration in sites in Onepoto and Pauatahanui over the survey years but is still below ANZECC 2000 ISQG-low trigger values (Oliver \& Conwell 2014; Oliver 2016).

\section{Porirua Harbour biodiversity}

The use of benthic flora and fauna as bioindicators of heavy metal contamination in estuaries is well established (Tomlinson et al. 1980; Subsandee et al. 2017). There have been a number of works on the fish fauna of Porirua Harbour that have established nursery habitat, abundance and movement of commercially important fish species such as snapper (Tāmure, Pagrus auratus), grey mullet (Kanae, Mugil cephalus), trevally (Arāra, Pseudocaranx georgianus) and rig shark (Pioke, Makō, Mangō, Mustelus lenticulatus) (Francis 2012b). Healy (1980) conducted the first significant fish survey of Porirua Harbour and recorded juvenile and immature flounder over the mud flats from Duck Creek to Horokiwi in Pauatahanui, and concluded Porirua Harbour was possible nursery habitat for this species. A significant reduction in fish has been observed and attributed to the degradation of the harbour (Francis 2013). However, little is known about heavy metal accumulation and overall health in the commercially and culturally important species that occupy Porirua Harbour.

\section{Study group 1: Flatfish}

Flatfish are members of the ray-finned demersal fishes or Pleuronectiformes and are found at the bottom of oceans worldwide (Baily 1997). Flatfish are characterized by asymmetry, with adult fish having both eyes on the same side of the head (Shao et al. 2017; Figure 2). Flatfish are nocturnal ambush predators that feed on a variety of bottom-dwelling invertebrates (Webb 1973). Flatfish typically have short lifespans of 3-4 years and mature at the age of 2 (Bailey 1997). New Zealand has 11 species of right-eyed flounder (Pleuronectidae) which are managed in the Quota Management System (QMS) (Stevens et al. 2005). Total commercial flatfish landing average at 2500 to 5000 tonnes per year (Stevens et al. 2005). 
Yellow belly flounder (Pātiki, tōtara, Rhombosolea leporina), sand flounder (Pātiki, Rhombosolea plebeia) and speckled sole (Peltorhamphus latus) are endemic flatfish species in New Zealand estuaries, harbours and inner continental shelves (Francis 2012b), and are characterized by high fecundity (Diggles et al. 2000). The speckled sole is a dwarf species of sole found throughout estuaries in the North Island and South Island down to a depth of $55 \mathrm{~m}$ (Francis 2013). However, little is known about the population dynamics of this species, and it is not targeted by commercial

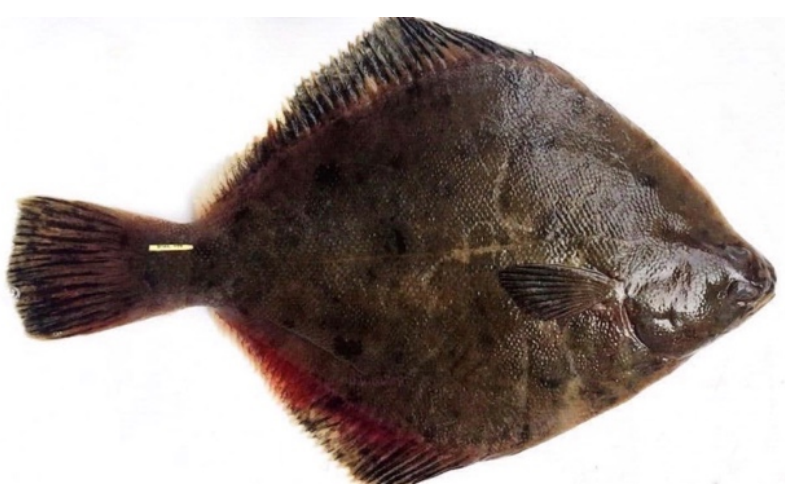
fisheries (Francis 2013; Munroe 2016).

\section{Flatfish in Porirua Harbour}

The relative abundance of flatfish in Porirua Harbour have been determined through the 2006 and 2013 NIWA fish surveys (Francis 2013). Yellow belly flounder, sand flounder, and speckled sole occupy both estuary arms (Francis et al. 2001; Francis 2012a; Francis 2013). The movement of flatfish between the two estuary arms has not been established.

Sand flounder have a minimum size limit of $23 \mathrm{~cm}$ under the Ministry of Primary Industries (MPI 2012). The NIWA 2013 survey caught juvenile fish through beach seines, whereas set nets caught adult fish (Francis 2013). Adult and juvenile age classes of sand flounder were observed by Healy (1980), who found lengths from $16-18 \mathrm{~cm}$ and $22-23 \mathrm{~cm}$ in Porirua Harbour.

Yellow belly flounder have a minimum legal size of $25 \mathrm{~cm}$ under the Ministry of Fisheries (MPI 2012). The 2013 NIWA survey did not collect any juvenile yellow belly flounder, which contrasted to Healy (1980) who found that both juvenile and adult fish were widespread throughout the year over the mud flats from Duck Creek to Horokiwi in Pauatahanui Inlet. Moreover, NIWA has concluded that spawning of yellow belly flounder occurs in deeper 
waters and they move into shallower water during the summer months. Therefore, juveniles may be absent from Porirua Harbour altogether (Francis 2013).

\section{Heavy metal accumulation in flatfish}

Flatfish are exposed to heavy metal accumulation primarily through their feeding ecology, as they are continuously submerged in sediment and ingest large amounts of benthic invertebrates and detritus (Francis 2012b). Heavy metal accumulation in flatfish around the world has been extensively reviewed since the 1970s. For example, hepatic lesions and diseases have been linked with contaminated sediments in the European Flounder (Platichthys flesus) (Myers et al. 1980; Van Leeuwen \& Vethaak 1988; Vethaak \& Wester 1993; Vethaak et al. 1996; Eggers et al. 1996). Heavy metal accumulation causing skin lesions has also been reviewed in the Senegalese sole (S. senegalensis) (Arellano et al. 1999) and winter flounder (P. americanus) (Bury et al. 2003).

In New Zealand, surveys in the Avon-Heathcote estuary have determined $\mathrm{Hg}$ and $\mathrm{Pb}$ concentration in sand flounder liver and muscle tissue is positively correlated with concentration found in their prey (EOS 2015). Accumulation in yellow belly flounder in the Manukau Harbour has also been extensively reviewed, with pathological gill and liver alterations and high parasite loads being characteristic symptoms of contaminated fish (Nenadic 1998; Diggles et al. 2000). In 2013, the first documented case of partial and complete albinism in New Zealand flounder was attributed to heavy metal pollution in water and sediment in Manukau Harbour (Jawad 2014). To date, there have been no studies undertaken on heavy metals in flatfish in Porirua Harbour.

\section{Study group 2: Elasmobranchs}

Elasmobranchs are cartilaginous fishes that include sharks, skates, and rays (Le Port \& Lavery 2011). Elasmobranchs are characterized by a range of distinctive life-history characteristics such as long life spans, slow growth rates, late maturity, low reproductive output and generally occupy high trophic levels (Le Port \& Lavery 2011). 


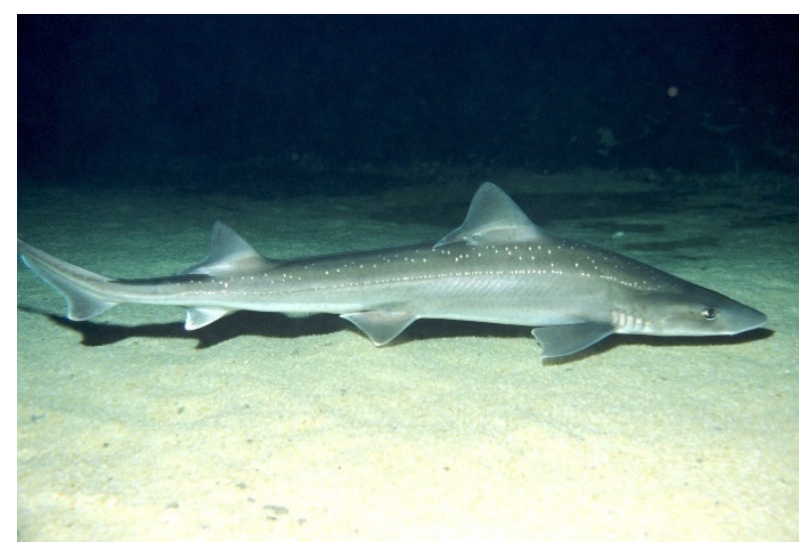

Figure 3: Photograph of an adult rig shark, photographed by Malcolm Francis, NIWA.

Rig shark (Pioke, Makō, Mangō, Mustelus lenticulatus) are an endemic species of benthic shark that inhabit coastal waters around New Zealand (Francis 2013; Figure 3). Sharks within the Mustelus genus are called 'smooth-hounds' and have commercial importance in a range of regions such as South Africa (Bosch et al. 2013), the Mediterranean (Storelli et al. 2002) and Australia (Gardner \& Ward 2002). Rig shark are fished commercially throughout New Zealand where they are marketed as 'lemon fish' and are commonly found in fish and chips (Ayling \& Cox 1984). Commercial landings in New Zealand averaged at 453, 692kg in 2018 (MAF 2018). Smooth-hounds are a slim shark characterized by a flattened ventral surface adapted for benthic feeding and teeth with bluntly rounded cusps adapted for invertebrate prey (Bosch 2012). Allozyme and mtDNA analysis has shown rig shark are genetically distinct from the Australian relative gummy shark (Mustelus antarcticus) (Gardner \& Ward 2002), but are closely related to species found in Norfolk Island and the Kermadecs (Getzlaff 2012). Both sexes of rig shark migrate to shallow coastal waters during spring, where females give birth to live young $25-30 \mathrm{~cm}$ long (Francis et al. 2013).

Eagle ray (Whai keo, Myliobatis tenuicaudatus) and short-tailed stingray (Whai, Dasyatis brevicaudata) are common around the North Island of New Zealand but are rarely found south of the Cook Strait (Francis 2012a; Figure 4). Both species typically occupy mud and sandy habitats but are often found near temperate reefs (Francis 2013), with the Poor Knight Islands established as a breeding ground for the short-tailed stingray (Le Port et al. 2012). During spring and summer, eagle ray and short-tailed stingray congregate in estuaries and shallow bays where they give birth to live young and feed on bivalves, crustaceans, and polychaetes (Francis 2012a). Both species are listed as 'least concern' under IUCN red list with little known about population trends (Duffy et al. 2016; Kyne 2016). 


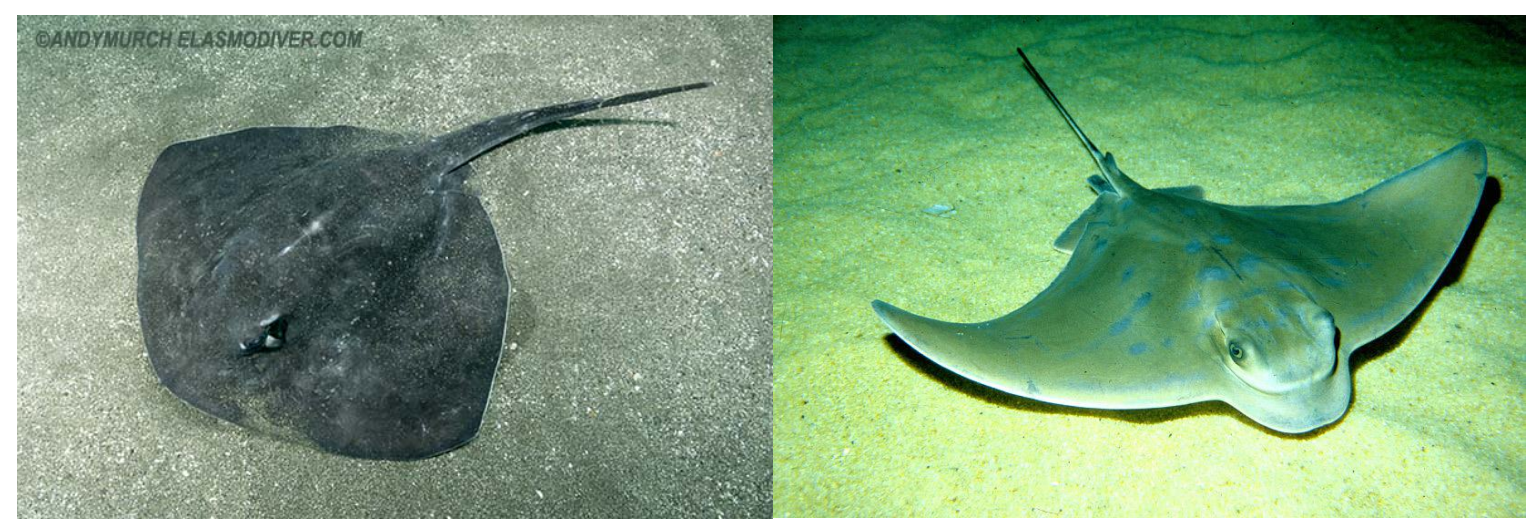

Figure 4: Photograph of Short tailed stingray (left) photographed by Andy Murch and eagle ray (right) photographed by Malcolm Francis, NIWA.

\section{Elasmobranchs in Porirua Harbour}

Jones and Hadfield (1985) first encountered eagle ray in Porirua Harbour set nets and they have since been encountered by Francis (2012a) and Francis (2013). Francis (2013) found new born short-tailed stingray (25-30 cm disc length) which suggested Porirua Harbour or nearby bays might be a pupping site or the inlet is nursery habitat for juvenile short-tailed stingrays.

Porirua Harbour has been established as the southernmost significant spawning and nursery area for rig shark, with no significant areas found in the South Island (Francis et al. 2012). Due to this, many works have been focused on this species alone, such as rig shark ecology (Francis \& Francis 1992), growth (Francis \& Ó Maolagáin 2000), and diet (Getzlaff 2012). Francis (2013) published a comprehensive review on juvenile rig shark movement and found juveniles have a preference for shallower mud banks within the harbour and avoid deeper channels with little movement between both estuary arms. Higher numbers of rig shark are found in Pauatahanui than in Onepoto, although adults and juveniles are present across both estuary arms (Healy 1980; Francis et al. 2012).

\section{Heavy metal accumulation in elasmobranchs}

Heavy metal accumulation in elasmobranchs, especially regarding $\mathrm{Hg}$, has been extensively studied (Walker 1976; Gelsleichter \& Walker 2010; Mull et al. 2012; Lyons et al. 2017). High levels of $\mathrm{Hg}$ in elasmobranchs are attributed to their long life span and high trophic positions, 
which allows biomagnification of pollutants from prey to predator and over time (Gelsleichter \& Walker 2010).

Storelli et al. (2002) published the first comprehensive description of heavy metal accumulation in Mustelus smooth-hound in the Mediterranean. Since then, metal accumulation of $\mathrm{Cu}, \mathrm{Al}$ and $\mathrm{Hg}$ has been established in smooth-hound in South Africa (Bosch 2012; Bosch et al. 2013). Muscle tissue is commonly examined due to human consumption risks, but few studies have examined the relationship between muscle and liver concentrations (Endo et al. 2016).

Sharks have been the focus of most heavy metal studies which leaves other elasmobranchs, like stingrays understudied (Lyons et al. 2017). Heavy metal concentrations in stingrays have been established in regions such as the Mediterranean (Turkmen et al. 2014), and Mexico, where stingray fisheries support 30\% of national fisheries production (Escobar- Sánchez et al. 2014). Round stingrays (Urobatis halleri) in California have shown $\mathrm{Hg}$ concentration was higher in adults than in juveniles, and stingrays in contaminated sites had accelerated accumulation (Lyons \& Lowe 2017).

\section{Aging flatfish and elasmobranchs}

The use of sagittal otoliths to age teleosts has been well established, especially in flatfish species (Reichert 1998; Reichert et al. 2000; Mille et al. 2015). In New Zealand, the first comprehensive review on the aging of yellow belly flounder and sand flounder was undertaken by Coleman (1974). However, using otoliths for aging does have its disadvantages, as the otolith nucleus doesn't necessarily form at hatch, so experimentation and observation are required to determine when the nucleus is first formed (Campana \& Jones 1992). Coleman (1974) interpreted the nucleus as the first year of growth for the yellow belly flounder and sand flounder, whereas a later study by Stevens et al. (2005) counted only the opaque rings.

Elasmobranchs are notoriously hard to age because they lack bony skeletons (Francis \& Maolagain 2000; Cahide \& Ismen 2016). Growth rates for rig shark are largely undetermined due to there being few data at the size of birth. Francis \& Francis (1992) published the first 
comprehensive review on rig shark age using length-frequency data, and established female rig had significantly higher growth rates than males in the South Island. However, a later study by Francis \& Maolagáin (2000) analyzed rig vertebrate and found no significant difference between male and female growth rates.

Stingrays are not a fisheries species, so size at maturity isn't well known. Other studies have used the thorny stingray (Dasyatis centroura) to estimate size at maturity for short tailedstingrays, which established males mature at $\sim 60-70 \mathrm{~cm}$ disk width (DW) for males, and $80-$ $100 \mathrm{~cm}$ for females (Le Port \& Montgomery 2008; Le Port 2009; Last et al. 2016). Vertebrae are used to age a range of elasmobranch species, but analytical techniques are difficult and time-consuming (Cahide \& Ismen 2016).

\section{Conclusion}

New Zealand estuaries are not exempt from degradation experienced worldwide, especially regarding heavy metal contamination. Estuaries have a substantial ecological function by providing nursery habitat for commercial and culturally significant fisheries but are vulnerable to heavy metal contamination through raw sewage, industrial, residential and farming runoff. Te Awarua-o-Porirua Harbour (Porirua Harbour) is the largest estuary in the southern North Island of New Zealand, and heavy metal contamination has become problematic following the introduction of intensive industry and development in the harbour catchment. The source and concentration of heavy metals in Porirua Harbour sediment have been extensively reviewed and is being monitored regularly. However, little is known about how these metals are accumulating in benthic fishes occupying this region. Porirua Harbour is an established nursery habitat for rig shark, and there is significant evidence that the short-tailed stingray also use this estuary as a nursery habitat. Flatfish are thought to be year-round residents in Porirua Harbour, but the movement of flatfish in this region has not been established. Moreover, the health and heavy metal accumulation in fish tissue have not been examined in this region. 


\section{Study objectives}

The overall aims of this research were to quantify heavy metal accumulation in benthic fishes in Porirua Harbour and to examine the movement of benthic fishes between the two estuary arms.

The specific objectives of this research were:

- To quantify levels of four heavy metals ( $\mathrm{Cu}, \mathrm{Zn}, \mathrm{Pb}$, and $\mathrm{Hg}$ ) in liver and muscle tissue of yellow belly flounder, sand flounder, speckled sole and rig shark caught in the Porirua Harbour and look for differences between sexes, tissue types, as well as effects of size and age.

- To quantify levels of four heavy metals ( $\mathrm{Cu}, \mathrm{Zn}, \mathrm{Pb}$, and $\mathrm{Hg}$ ) in muscle tissue biopsies from eagle ray and short-tailed stingray caught in the Porirua Harbour and look for differences between sexes, as well as effects of size and age.

- To examine relationships between contaminant loads of pregnant female rig sharks and those of their near-term embryos.

- To examine each fish sampled for general metrics of health (parasite load, skin lesions, etc.) as well as examine stomach contents to quantify diet, and look for relationships with body burdens of metals.

- To examine the movement of benthic fishes between the two arms of Porirua Harbour (Onepoto and Pauatahanui) using mark-recapture methods. 


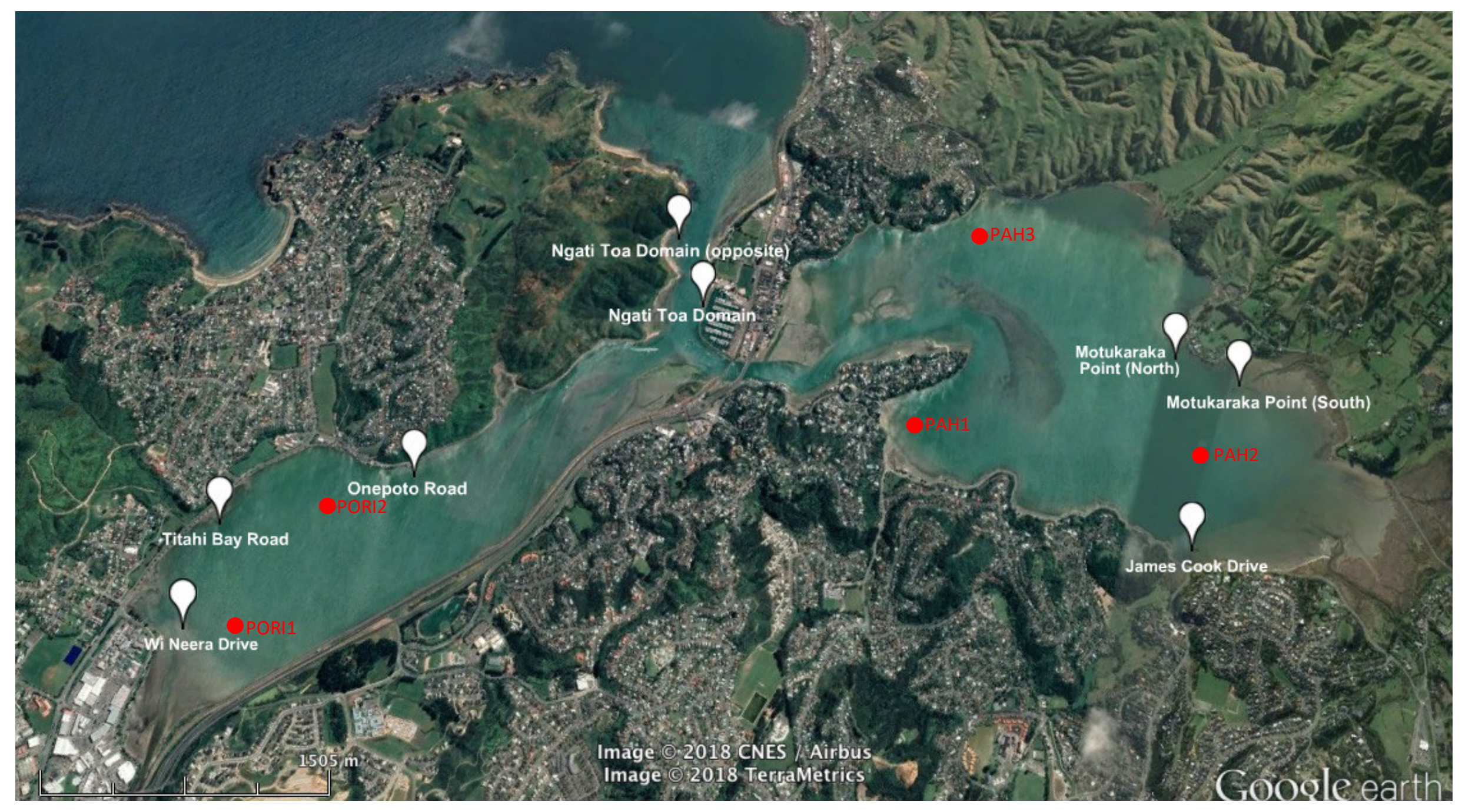

Figure 5: Arial map of sites sampled in Porirua Harbour. Wi Neera Drive, Titahi Bay Road and Onepoto Road (In Onepoto Arm), Ngati Toa Domain (Harbour entrance), Motukaraka Point and James Cook Drive (Pauatahanui Inlet). A flounder-spear was used at Ngati Toa Domain and James Cook Drive, and netting was used at all other sites. PORI 1-2 and PAH 1-3 are sites where sediments were sampled for heavy metals in 2015/2016 by Oliver (2016). Retrieved from Google Earth 17/12/2018. 


\section{Methods}

\section{Data Collection}

Sampling from the field

Fish were collected from 8 sites in Porirua Harbour (Figure 5) over a four-month period (March-August 2018) under the Ministry for Primary Industries Special Permit \#563. A range of fishing techniques targeting benthic fish were used across different sites depending on suitability. A flounder net is a set net with its headline 'tied down' every $4 \mathrm{~m}$ to the ground line, a method used by commercial flounder fisherman because the catchability of flounder in ordinary set nets is low (Francis 2012a). Flounder nets are not specific to flounder and target all benthic and demersal fishes, such as rig shark and stingrays. Flounder nets were anchored to the seafloor with two $4 \mathrm{~kg}$ anchors and were set by shore or dingy at low tide and collected after $6 \sim 12$ hours. Mesh used for flounder nets was a $0.28 \mathrm{~mm}$ monofilament twine with a stretched mesh size of $118 \mathrm{~mm}$ ( 4.75 inches), a length of $30 \mathrm{~m}$, a height of 25 meshes, a $50 \%$ slinging ratio and a headline and ground line made of $5 \mathrm{~mm}$ diameter braided rope. A dragnet was used when conditions and water clarity was suitable at low tide. The mesh used was 18 ply twine with a stretched mesh size of $114.3 \mathrm{~mm}$ ( 4.5 inches), a length of $15 \mathrm{~m}$, a height of 25 meshes. In areas unsuitable for netting, a flounder-spear and torch were used to collect flatfish in the dark at high or low tide, a traditional way of collecting flatfish worldwide (Pickard 2007).

Collection methods were not designed to provide a representative sample of fish in Porirua Harbour. Netting is selective and only samples part of the population (i.e. only juveniles or adults) (Francis 2012b). Four-inch mesh allowed only the adult populations to be sampled, whereas the flounder-spear was more selective towards juvenile flatfish.

\section{Fish preparation}

Biological measurements including Total Length ( $T L)$, sex and species identification were achieved in the field. Live fish were tagged with type-2 TBA anchor tags and released for a mark-recapture study (Appendix B), and deceased fish were kept for quantifying traits and heavy metal analysis (Appendix A). Whole fish were rinsed with de-ionized water (DI) before 
freezing to remove absorbed metals on the skin (Yılmaz 2007). Fish were stored in sterile polyethylene bags and kept on ice before being frozen at $-18^{\circ} \mathrm{C}$ until dissection. Additional measurements of short-tailed stingray and eagle ray such as Disk Width (DW) and Tail Length was achieved in the field. A $0.5 \mathrm{~g}$ biopsy of left-wing tissue was removed and kept in sterile Nasco Whirl-Pak and kept on ice until frozen at $-18^{\circ} \mathrm{C}$.

\section{Fish tagging}

Type TBA anchor tags purchased from Hallprint were used in the mark/recapture component in this study. Individuals were removed from the net and placed in tanks of water before having sex Total Length, and any notable parasites and lesions recorded. Stingrays had sex, Total Length, Disk Width (DW), and Tail Length recorded immediately before being released back into the estuary. Flatfish were tagged in the left side of their tail fin, rig shark and other fishes were tagged to the left of their dorsal fin, and stingrays were tagged on their right pelvic fin (Appendix B).

\section{Dissection protocol}

In the laboratory, fish were thawed and total weight $(\mathrm{g})$ as well as any visible metrics of health were recorded (parasites, lesions Appendix C). Total length was recorded prior to freezing (as above) in case of shrinkage, as elasmobranchs are known to shrink when frozen and thawed (Hadfield 1985). Additional measurements such as First Dorsal Length (FDL), Head Length (HL), Pre Orbital Length, Pre Oral Length, and Mouth Width (MW) were obtained from rig shark (Appendix D). The abdominal cavity was cut open using sterile ceramic dissection tools. Whole liver of adult rig shark and flatfish was removed, weighed (g), and a $2 \mathrm{~g}$ wet weight (w.w) tissue sample was taken from liver and stored on ice. Hepatosomatic index (HSI) was estimated as an indicator of overall health of the fish, as it is associated with metabolic

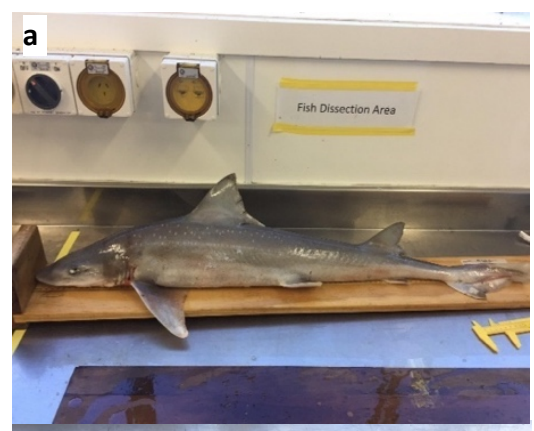

b)

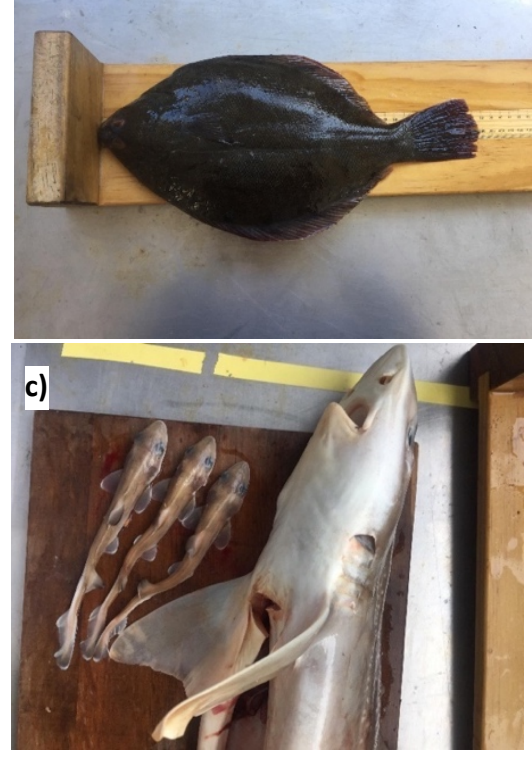

Figure 6: Photograph of a) adult rig shark, b) yellow belly flounder, and c) adult female rig shark and near-term embrvos. 
activity and lipid reserves (Bolger 2013). The average HSI was calculated through the following formula from Yang (2006);

$$
\mathrm{HSI}=\text { weight of liver } \times \frac{100}{\text { total weight }(\mathrm{g})}
$$

$2 \mathrm{~g}$ w.w muscle tissue was removed from the epaxial tissue on both sides of the rig shark to ensure an even representation, and from the underside of flatfish. Muscle tissue was stored on ice until further analysis.

\section{Stomach analyses}

A qualitative assessment of stomach fullness was made by using the volume occupied by stomach contents, and classifying as empty, trace, half full and full. Stomach contents of each fish were emptied and rinsed through $500 \mu \mathrm{m}$ sieve before being placed in petri dishes. Recognisable prey items were identified to the lowest taxon possible, using a dissecting microscope when necessary. Stomach contents from flatfish bellow $14 \mathrm{~cm}$ were not sieved due to $500 \mu \mathrm{m}$ being too wide for the stomach contents. The contribution of prey items to the diet of Porirua Harbour fish was assessed using the frequency of occurrence (\% F). \%F was calculated as $n_{\text {prey }} / n_{\text {total }}$ where $n_{\text {prey }}$ is the number of fish stomachs containing prey and $n_{\text {total }}$ is the total number of stomachs examined (Berg 1979; Baker et al. 2014).

\section{Aging}

To age flatfish, samples of sagittal otoliths were collected. Otoliths were removed from the fish during dissection and stored, untreated in envelopes before being examined under a dissecting microscope. As in most flatfish, the otoliths of yellow belly flounder and sand flounder are asymmetrical, where the left otolith is broader and least distorted than the right otolith and is often preferred (Stevens et al. 2005). In flatfish, the otolith nucleus was opaque and surrounded by a succession of translucent (hyaline) and opaque rings (Coleman 1974). Opaque rings from the left sagittal otolith were counted and used to estimate the age of flatfish, following the protocol of Stevens et al. (2005). Although some fish species are known to lay down opaque rings seasonally, it is well established that flatfish have annual growth on their sagittal otolith (Reichert 1998). 
Rig shark age was estimated by weight (g) and Total Length (TL) following Francis (1992). Estimated age for stingrays was not obtained, but they were classified as 'mature' following the methods by Le Port \& Montgomery (2008), Le Port (2009) and Last et al. (2016).

\section{Maturity}

Elasmobranchs were externally sexed by the presence or absence of claspers. Male sexual maturity was assssed macroscopically by examination of the testes, vas deferens and determining if the claspers were calcified. A three-stage macroscopic scale was used to classify sexual maturity for males (Table 3).

Table 3: Macroscopic maturity stages to evaluate sexual maturity of male rig shark, adapted from Frisk (2009).

\begin{tabular}{lll} 
& Stage & Description \\
\hline Immature & 1 & Claspers: non calcified. \\
& Testes: narrow and threadlike. \\
& Vas deferens: straight. \\
\hline Maturing & 2 & Claspers: partially calcified. \\
& & Testes: Thickening and becoming wider. \\
& & Vas deferens: beginning to coil. \\
\hline Mature & 3 & Claspers: fully calcified. \\
& & Testes: Wide. \\
& Vas deferens: fully coiled.
\end{tabular}

Female elasmobranch sexual maturity was assessed macroscopically by examination of the ovaries and uteri. A six-stage macroscopic scale was used to classify sexual maturity (Table 4). If embryos were present, the embryos were sexed and weighed $(\mathrm{g})$, Total Length $(\mathrm{cm})$ and the number of embryos in each uterus was recorded. Rig shark embryos were rinsed with deionized water, placed in sterile Nasco Whirl-Pak and frozen at $-18^{\circ} \mathrm{C}$ until analysis. Dissection 
of the rig shark embryos and removal of muscle tissue followed the same protocol described above for adults.

Table 4: Macroscopic maturity stages to evaluate female elasmobranch sexual maturity, adapted from Frisk (2009).

\begin{tabular}{|c|c|c|}
\hline & Stage & Description \\
\hline Immature & 1 & $\begin{array}{l}\text { Ovaries: Barely visible. } \\
\text { Uteri: narrow and threadlike. }\end{array}$ \\
\hline Maturing & 2 & $\begin{array}{l}\text { Ovaries: Oocytes of different } \\
\text { sizes present, but none larger } \\
\text { than } 5 \mathrm{~mm} \text {. } \\
\text { Uteri: Thickening. }\end{array}$ \\
\hline Pre-ovulatory & 3 & $\begin{array}{l}\text { Ovaries: Oocytes larger than } \\
5 \mathrm{~mm} \text {, pale yellow in colouration. } \\
\text { Uteri: Thick and wide. }\end{array}$ \\
\hline Early Pregnancy & 4 & $\begin{array}{l}\text { Ovaries: Flaccid. } \\
\text { Uteri: fertilized eggs present and } \\
\text { candles (membranous capsule } \\
\text { surrounding egg). }\end{array}$ \\
\hline Pregnant & 5 & $\begin{array}{l}\text { Ovaries: flaccid with remnants of } \\
\text { oocytes. } \\
\text { Uteri: contain visible embryos } \\
\text { (pups) at different stages of } \\
\text { development. }\end{array}$ \\
\hline Post-partum & 6 & $\begin{array}{l}\text { Ovaries: flaccid. } \\
\text { Uteri: flaccid, indicating recent } \\
\text { birth. }\end{array}$ \\
\hline
\end{tabular}

Flatfish sexual maturity was assessed macroscopically by examination of the gonads. A 5stage macroscopic scale was used (Table 5). 
Table 5: Macroscopic maturity stages to evaluate sexual maturity of flatfish, adapted from Stevens et al. (2010).

\begin{tabular}{|c|c|c|c|}
\hline Sex & Stage & Description & Biological Activity \\
\hline \multirow[t]{5}{*}{ Males } & 1 & $\begin{array}{l}\text { Testes transparent and } \\
\text { threadlike }\end{array}$ & Immature \\
\hline & 2 & $\begin{array}{l}\text { Testes threadlike with } \\
\text { lobing visible }\end{array}$ & Maturing \\
\hline & 3 & $\begin{array}{l}\text { Testes large and multi- } \\
\text { lobed with a pink/white } \\
\text { colouration }\end{array}$ & Mature \\
\hline & 4 & $\begin{array}{l}\text { Testes large, multi- } \\
\text { lobed and blood shot. } \\
\text { Milt present. }\end{array}$ & Running ripe \\
\hline & 5 & $\begin{array}{l}\text { Testes thin, blood shot } \\
\text { and bruised with no milt } \\
\text { present }\end{array}$ & Spent \\
\hline \multirow[t]{5}{*}{ Females } & 1 & $\begin{array}{l}\text { Ovaries transparent and } \\
\text { thread like }\end{array}$ & Immature \\
\hline & 2 & $\begin{array}{l}\text { Ovaries creamy white } \\
\text { and swollen }\end{array}$ & Maturing \\
\hline & 3 & $\begin{array}{l}\text { Ovaries large and } \\
\text { swollen with oocytes } \\
\text { present }\end{array}$ & Mature \\
\hline & 4 & $\begin{array}{l}\text { Ovaries swollen with } \\
\text { oocytes running free } \\
\text { with slight pressure }\end{array}$ & Running Ripe \\
\hline & 5 & Ovaries dark and flaccid & Spent \\
\hline
\end{tabular}




\section{Laboratory Protocol}

\section{Tissue preparation}

An acidic solution of $20 \%$ hydrochloric acid $(\mathrm{HCl})$ was used to rinse laboratory vials and dissection equipment between fish samples, followed by a rinse in di-ionized water (DI) 4times and left to air dry. Following dissection with sterile ceramic tools, tissue samples were placed in pre-washed vials with DI, washed in an ultrasonic bath 4-times for 30 seconds with DI replaced every cycle. Samples were placed in individual aluminum trays and dried at $70{ }^{\circ} \mathrm{C}$ for 48 hours, or until they weighed a constant weight. Once dried, samples were ground in mortar and pestle, weighed and stored in individual Nasco Whirl-Pak bags in a desiccator.

\section{Heavy metal analysis}

Muscle and liver tissue samples from flatfish and rig shark were analysed by Eurofin, a Wellington Environmental Laboratory Service, accredited by the internationally Accreditation New Zealand (IANZ). Inductively coupled plasma mass spectrometry (ICPMS) was used to measure the concentrations of copper $(\mathrm{Cu})$, zinc $(\mathrm{Zn})$, lead $(\mathrm{Pb})$ and mercury $(\mathrm{Hg})$ (Table 6). Nitric (HNO3) and $\mathrm{HCl}$ acid were used to digest the tissue samples in preparation for ICPMS.

Eagle ray and short-tailed stingray muscle tissue were transported on ice to the University of Waikato to be assayed with ICPMS in conjunction with a PhD research project. Tissue for small flatfish $(<14 \mathrm{~cm} \mathrm{TL})$ were pooled into a single sample each for muscle and liver to meet the Detection Limits for metal analysis (Table 6). This included speckled sole $(n=10)$ and sand flounder $(n=2)$ in this size range. 
Table 6: Detection Limit for the metals $\mathrm{Cu}, \mathrm{Zn}, \mathrm{Pb}$ and $\mathrm{Hg}$ in Inductively Coupled Plasma Mass Spectrometer (ICPMS).

\begin{tabular}{ll}
\hline Test & Detection Limit \\
\hline Copper (Cu) & $0.05 \mathrm{mg} / \mathrm{kg}$ \\
\hline Zinc (Zn) & $0.1 \mathrm{mg} / \mathrm{kg}$ \\
\hline Lead (Pb) & $0.01 \mathrm{mg} / \mathrm{kg}$ \\
\hline Mercury (Hg) & $0.01 \mathrm{mg} / \mathrm{kg}$ \\
\hline
\end{tabular}

\section{Moisture content}

Elemental levels were expressed as $\mathrm{mg} / \mathrm{kg}$ of dry weight (d.w). The mean moisture content in liver was $81.6 \%$ for flatfish and $78 \%$ in rig shark and mean moisture content in muscle was $85.1 \%$ for flatfish and $83.4 \%$ for rig shark. These values were used for the conversion of results to a wet weight basis (w.w) for comparisons with other studies. Dry mass concentrations were converted to wet mass concentrations by the following theoretical conversion formula given by Pierre \& Cresson (2017);

$$
C w=C d x\left(\frac{100-\% H}{100}\right)
$$

Where $C w$ and $C d$ are the wet and dry concentrations respectively, and $\% H$ is the percentage of humidity in wet weight tissues. Elemental levels in rig shark embryo muscle tissue were kept at a dry weight (d.w) as they did not need to be compared with international regulations.

\section{Sediment concentrations}

Heavy metal levels $(\mathrm{Cu}, \mathrm{Zn}, \mathrm{Pb}, \mathrm{Hg}$ ) found in sediment during the survey undertaken by Oliver (2016) were used for comparison with heavy metal levels present in fish tissue. Sediment concentrations across five sites in Porirua Harbour (three in Pauatahanui, two in Onepoto) were measured in $\mathrm{mg} / \mathrm{kg}$ dry weight (d.w) and were pooled together for comparison with $\mathrm{mg} / \mathrm{kg} \mathrm{d.w}$ levels present in this study. Results in this section were expressed as $\mathrm{mg} / \mathrm{kg} \mathrm{d} . \mathrm{w}$. 


\section{Statistical analyses}

All analyses were conducted in R V3:5:1 (R-Core-Team 2016) using RStudio V1.1.456 (R-Team 2015). Speckled sole and stingray results were mostly excluded from heavy metal analysis due to the speckled sole being pooled into single samples for muscle and liver, and because stingray muscle samples were processed at a different laboratory.

Heavy metal data $(\mathrm{Cu}, \mathrm{Zn}, \mathrm{Pb}, \mathrm{Hg}$ ) across two tissue types (muscle and liver) and species (flatfish, rig shark) were first checked for homogeneity of variance and normality by means of Levens and Shapiro-Wilk tests respectively. In the case of departures from these assumptions, data were log- transformed or non- parametric Kruskal Walis tests were used. Relationships between biological characteristics such as TL, weight, age, sex, and relationships between metal concentration across tissue types (muscle and liver), within and between species were tested with one and two way ANOVA using the aov.function. Post hoc tests on maturation status and TL/weight were run using the TukeyHSD function in the multicomp package. Kruskal Wallis was used to test $\mathrm{Pb}$ concentration across sex in rig shark. For each analysis for both flatfish and rig shark, an ANCOVA on each metal concentration ( $\mathrm{Cu}, \mathrm{Zn}, \mathrm{Pb}, \mathrm{Hg}$ ) was run initially that included sex as a fixed factor (female and male for flatfish, male, pregnant female and pre-ovulatory female for rig shark) with either TL or weight as the covariate. Because metal concentration never varied significantly by sex, it was removed as a factor and regressions of relationships with either TL or weight only presented, with data pooled across the sexes. Linear and polynomial regression were tested with GLM using the nnet package, where the 2nd and 3rd polynomial were used respectively.

Because there was no statistically significant difference across sites for heavy metal levels in fish, heavy metal levels in sediment were pooled together across sites (three in Pauatahanui, two in Onepoto). Mean heavy metal levels in sediment were compared with mean heavy metal concentrations in species and tissue with a One-way ANOVA.

Heavy metal data $(\mathrm{Cu}, \mathrm{Zn}, \mathrm{Pb}, \mathrm{Hg})$ in mother rig shark tissue (muscle/liver) and rig shark embryo tissue (muscle) were first checked for homogeneity of variance and normality by the Levene's and Shapiro-Wilk tests respectively, following the same procedures as above. 
Relationships between mother and embryo heavy metal concentration were tested using linear regression with LM.function, as well as relationships between embryo metal concentration and biological characteristics such as mother TL/weight and embryo TL/weight. Linear regression was also used to assess the relationship between heavy metal burden per embryo and litter size. Relationships between overall heavy metal burden across tissue types (embryo muscle, mother muscle, and mother liver) were tested with one and two-way ANOVA using the aov.function. 


\section{Results}

No significant effect was found for stomach fullness, parasite load, season, HSI, location and date of fish captured on any of the metal concentrations, so they were excluded from further analyses and results.

\section{Biological characteristics}

\section{Size composition}

The total length (TL) for flatfish ranged from $24-33 \mathrm{~cm}$ in males $(n=4)$ and $10-45.5 \mathrm{~cm}$ in females ( $n=22$; Figure 7a). The TL for elasmobranchs (rays and rig shark) ranged from 80-90 $\mathrm{cm}$ in males $(n=5)$, and $47-107 \mathrm{~cm}$ in females ( $n=21$; Figure 7b). Rig shark embryos $(n=69)$ were collected from 13 litters and ranged in length from 11 to $21 \mathrm{~cm}$ (Figure 7c).

a)

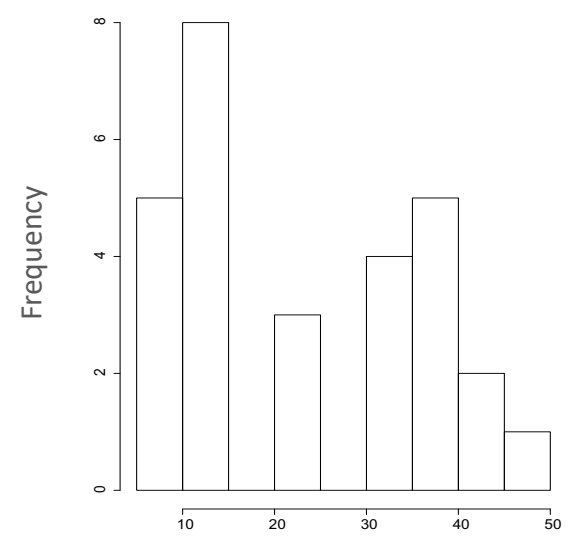

b)

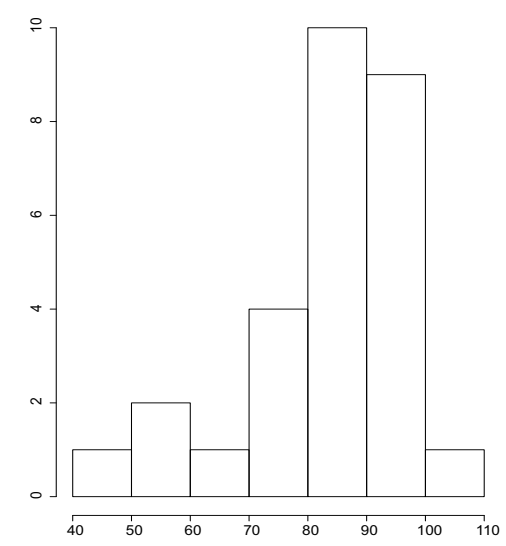

Total Length $(\mathrm{cm})$ c)

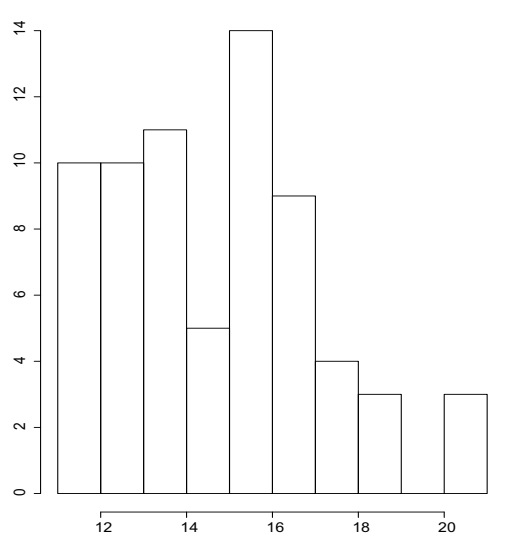

Figure 7: Total length- frequency distribution for a) yellow belly flounder, sand flounder, speckled sole $n=26, b$ ) elasmobranchs (rig shark, eagle ray, short tailed stingray) $n=26, c)$ rig shark embryos $n=69$, collected from Porirua Harbour in 2018, excluding individuals that were tagged/released.

\section{Length- weight relationships}

Weight increased with TL for flatfish $(r=0.98, n=26, p=<0.001)$, rig shark $(r=0.83, n=21, p$ $=0.0036)$ and rig shark embryos $(r=0.92 n=69, p=<0.001)$ (Figure 8). Length- weight relationships were not obtained for eagle ray and short-tailed stingrays because weight was not collected in the field. 
a)

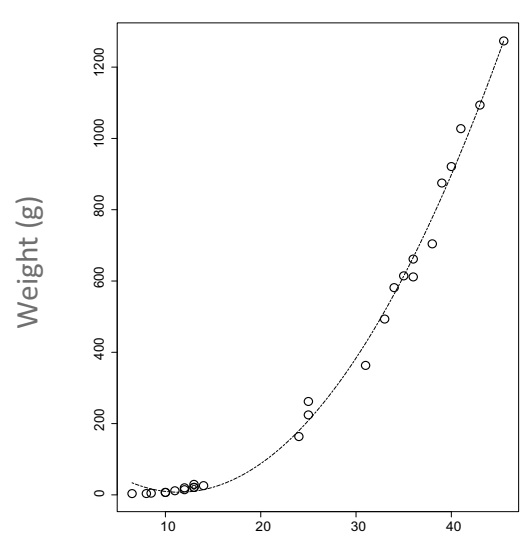

b)

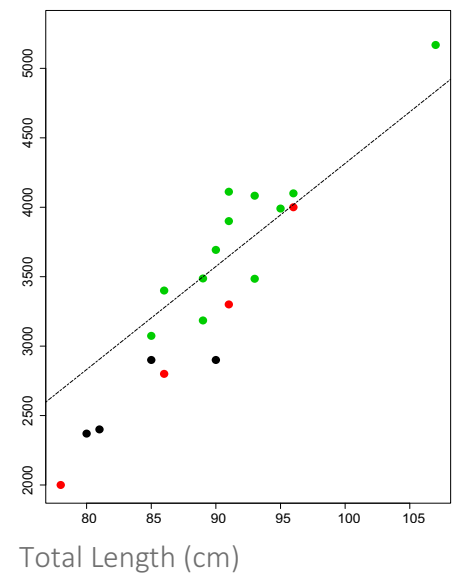

c)

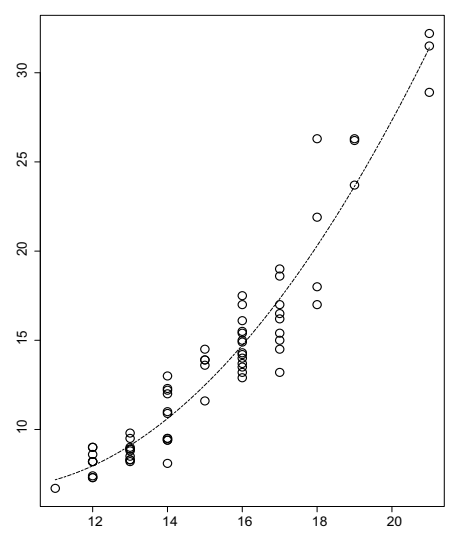

Figure 8: Length-weight linear and non-linear regression fit models for a) yellow belly flounder, sand flounder, speckled sole $n=26, b$ ) adult rig shark $n=21$ (green = pregnant females, red = pre-ovulatory females, black= males), and c) rig shark embryos collected from Porirua Harbour in 2018, excluding individuals that were tagged/released.

Age

In flatfish, sagittal otolith age ranged from 0+-3+ years. When flatfish were pooled across all species, those aged $2+$ and $3+$ did not increase in size, weight and age as they were dominated by speckled sole that had a maximum weight of $25.9 \mathrm{~g}$, a TL of $14 \mathrm{~cm}$ and were aged 2-3+ years (Figure 9c). With speckled sole removed from analysis, the average age was $0+-2+$ for flatfish (yellow belly flounder and sand flounder) included in heavy metal analysis (Figure 9a, b). The term 'flatfish' from here on excludes speckled sole.

Weight and TL increased with age for rig shark $(r=0.37, n=21, p=0.0036)$. The average age for rig was 6 for males and 7 for females. Age was unable to be obtained from short-tailed stingray and eagle ray.
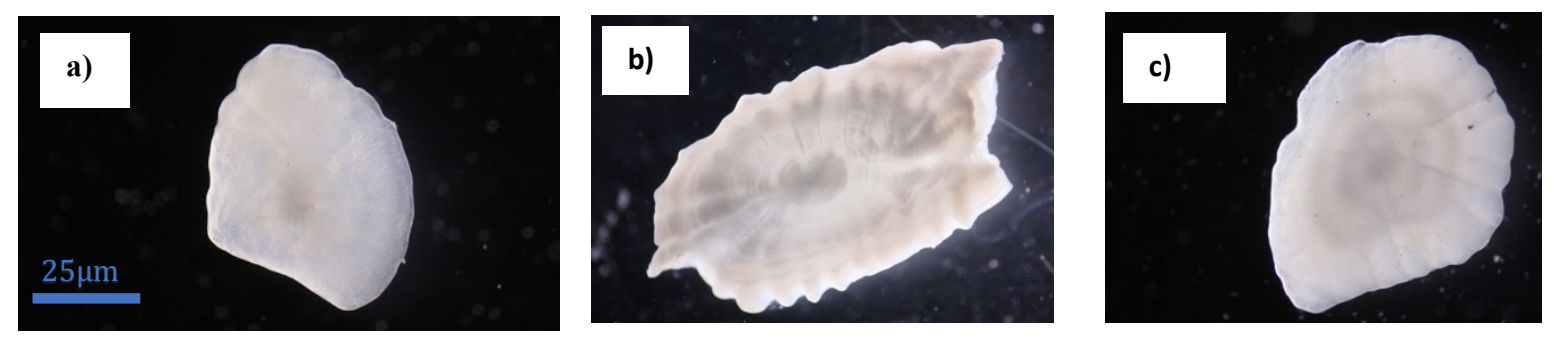

Figure 9: Sagittal otolith of a) $13 \mathrm{~cm}$ female sand flounder aged $0+$ years, b) $43 \mathrm{~cm}$ female yellow belly flounder aged $2+$ years, c) $12 \mathrm{~cm}$ female speckled sole aged $2+$ years. Photographed by Liana Cook-Auckram.

\section{Sex and Maturation}

Flatfish were female dominant with $72 \%$ of flatfish captured being female. TL (one-way ANOVA: $\left.F_{1,15}=9.44, p=0.0009\right)$ and weight $\left(F_{1,15}=8.35, p=0.0044\right)$ both varied by sex, with 
females being larger than male flatfish (Figure 10a). Of the 14 female flatfish captured, 30\% were classified as 'spent' with $13 \%$ running ripe and the remainder classified as stage 3 . Males were classified as 'partially spent' $n=4$.

a)

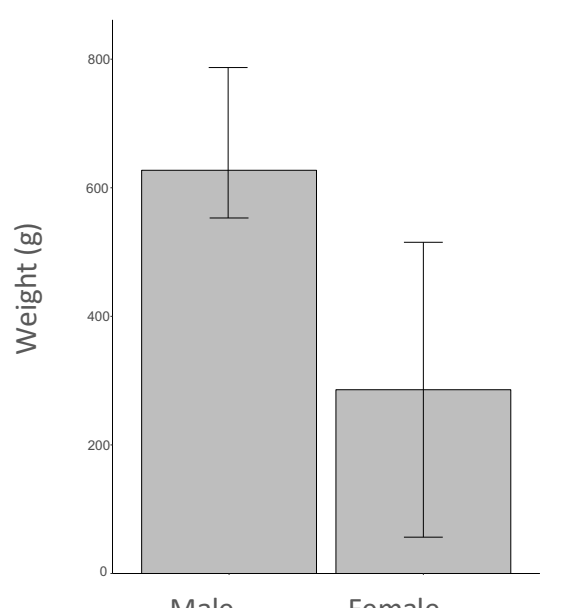

Male Female b)

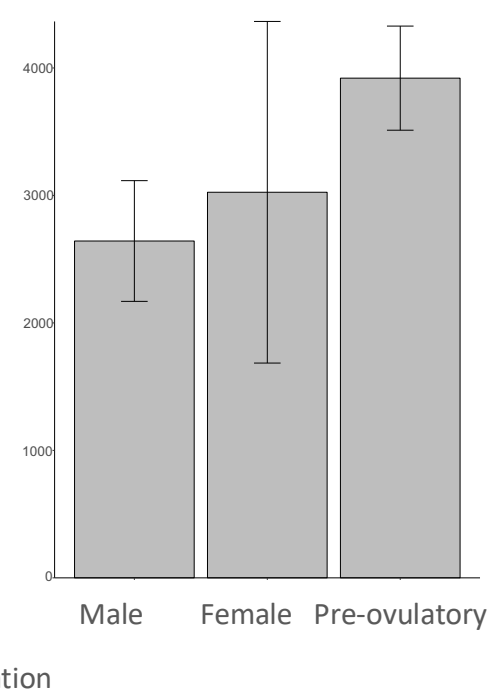

Figure 10: The relationship between sex and weight (g) for a) flatfish (yellow belly flounder and sand flounder), and b) rig shark caught from Porirua Harbour in 2018. Error bars represent standard errors.

Rig shark were also female dominant with $81 \%$ of rig captured being female. The model identified no significant difference between sex and TL of male sharks due to the small sample size $n=4$, so these were poorly represented (the model was dominated by females). Pregnant females (with embryo weight removed) weighed more than males and pre-ovulatory females (one-way ANOVA: $\mathrm{F}_{2,18}=7.30, \mathrm{p}=0.0048$ ) (Figure 10b). However, pre-ovulatory rig shark females did not significantly differ in weight from males (Tukey post hoc: 0.6957) (Figure 10b). Pregnant females, pre-ovulatory females and males did not vary in TL (one-way ANOVA: $\left.F_{2,18}=1.93, p=0.1746\right)$.

$76 \%$ of female rig shark were pregnant, with a total of 13 litters (litter size ranging from 2-7 embryos per litter). Rig shark embryos were also female dominant with $60 \%$ of the pups being female. There was no difference between male and female embryo weight or TL (one-way ANOVAs: $p=>0.05$ ). 


\section{Diet Composition}

Of the 49 fish stomachs sampled, 3 stomachs were empty (6.12\%), 6 contained unidentifiable digested prey (fullness was described as "trace"), (12\%), 26 stomachs were half full (53\%) and 14 were considered full (29\%). A qualitative assessment of stomach fullness was assessed using frequency of occurrence $(\% \mathrm{~F})$.

The diet of flatfish was dominated by the bivalve pipi (Paphies australis) (\%F = 87\%). The second-most-commonly identified prey type was the stalk-eyed mud crab (Hemiplax hirtipes) $(\% \mathrm{~F}=46 \%)$ (Figure 11a), followed by polychaete worms (\%F=13\%). Other crustaceans such as ostracods and cumaceans were present $(\% \mathrm{~F}=0.06 \%, 0.06 \%)$. The diet of speckled sole was dominated by cumaceans and polychaete worms $(\% \mathrm{~F}=$ 70\%). The second-most-commonly identified prey item was ostracods $(\% \mathrm{~F}=30 \%)$ followed by pipi, formanifera and amphipods (\%F=10\%) (Table 7).

The diet of rig shark was dominated by crustaceans, particularly the stalk-eyed mud crab $(H$. hirtipes) $(\% \mathrm{~F}=$ 100). The hairy- handed crab (Hemigrapsus crenulatus) was the second-most- commonly identified crustacean $(\% \mathrm{~F}=57 \%)$ (Figure $11 \mathrm{~b}, \mathrm{c})$. Other crustaceans such as the tunnelling mud crab (Helice crassa) and the red rock crab (Hemigrapsus sexdentatus) were found but in lower abundance $(\%=F 10 \%, 0.04 \%)$ (Table 7).

Overall, the most common prey item in Porirua Harbour fish sampled were the stalk-eyed mud crab $(H$. hirtipes) (\%F=61\%), hairy-handed crab (H. crenulatus) $(\% \mathrm{~F}=30 \%)$ and pipi (P. australis) $(\% \mathrm{~F}=28 \%)$. Vegetable matter $(\% \mathrm{~F}=17 \%)$ and plastic $(\% \mathrm{~F}=13 \%)$ was also found in fish stomachs, although their occurrence was low (Table 7).
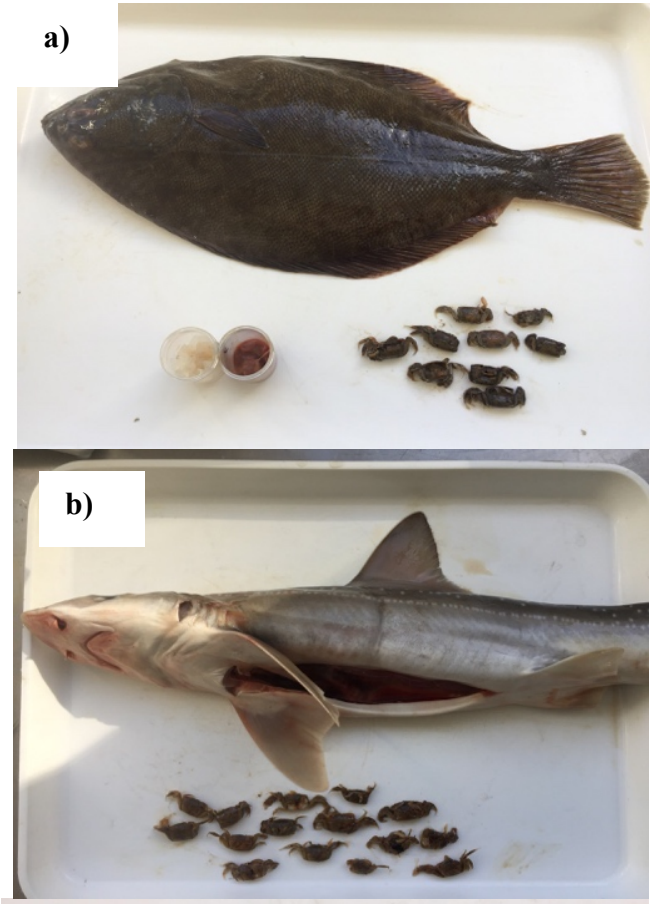

c)

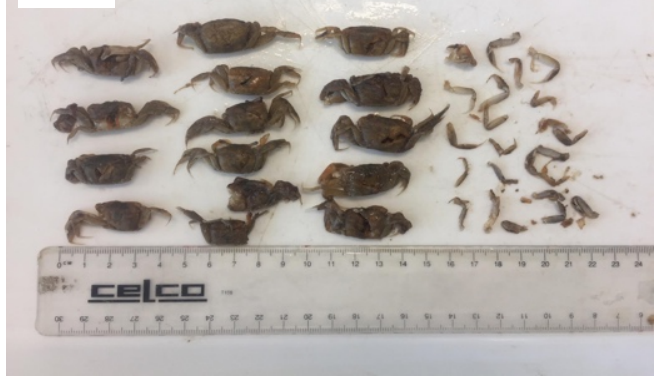

Figure 11: The stalk-eyed mud crab $H$. hirtipes found in the stomach contents of a) yellow belly flounder (muscle and liver samples photographed) and b), c) rig shark. 
Table 7: Percentage frequency (\%F) of prey items in the stomachs of flatfish (yellow belly flounder and sand flounder), speckled sole and adult rig shark collected from Porirua Harbour in 2018, excluding individuals that were tagged/released.

\begin{tabular}{|c|c|c|c|c|}
\hline Prey Items & $\begin{array}{l}\text { \% Frequency } \\
\text { Speckled sole }\end{array}$ & $\begin{array}{l}\text { \% Frequency } \\
\text { Flatfish }\end{array}$ & $\begin{array}{l}\% \\
\text { Frequency } \\
\text { Rig shark }\end{array}$ & $\begin{array}{l}\text { \% Frequency } \\
\text { Total }\end{array}$ \\
\hline \multicolumn{5}{|l|}{ Crustacea } \\
\hline Hemiplax hirtipes & - & $46 \%$ & $100 \%$ & $61 \%$ \\
\hline Hemigrapsus crenulatus & - & $13 \%$ & $57 \%$ & $30 \%$ \\
\hline Hemigrapsus sexdentatus & - & - & $0.04 \%$ & $0.02 \%$ \\
\hline Helice crassa & - & - & $10 \%$ & $0.04 \%$ \\
\hline Ostracods & $30 \%$ & $0.06 \%$ & - & $0.07 \%$ \\
\hline Cumaceans & $70 \%$ & $0.06 \%$ & - & $17 \%$ \\
\hline Amphipods & $10 \%$ & - & - & 0.025 \\
\hline \multicolumn{5}{|l|}{ Bivalvia } \\
\hline Paphies australis & $10 \%$ & $87 \%$ & - & $28 \%$ \\
\hline \multicolumn{5}{|l|}{ Polychaeta } \\
\hline Unidentified spp. & $70 \%$ & $13 \%$ & - & $20 \%$ \\
\hline \multicolumn{5}{|l|}{ Formanifera } \\
\hline Unidentified spp. & $10 \%$ & $0.06 \%$ & - & $0.04 \%$ \\
\hline \multicolumn{5}{|l|}{ Parasites } \\
\hline Nematode & - & $13 \%$ & $29 \%$ & $17 \%$ \\
\hline Unidentified spp. & $10 \%$ & - & - & $0.02 \%$ \\
\hline \multicolumn{5}{|l|}{ Other } \\
\hline Vegetation & $10 \%$ & $0.06 \%$ & $29 \%$ & $17 \%$ \\
\hline Plastic & - & $0.06 \%$ & $24 \%$ & $13 \%$ \\
\hline Unidentifiable & - & $0.08 \%$ & $19 \%$ & $15 \%$ \\
\hline \multicolumn{2}{|c|}{ Number of flatfish stomachs with prey } & 15 & & \\
\hline \multicolumn{2}{|c|}{ Number of rig shark stomachs with prey } & 21 & & \\
\hline \multicolumn{2}{|c|}{ Number of speckled sole stomachs with prey } & 10 & & \\
\hline \multicolumn{2}{|c|}{ Total number of stomachs } & 46 & & \\
\hline
\end{tabular}




\section{Parasites and lesions}

Although there was no statistically significant relationship between parasite, lesions and total heavy metal burden in this present study, they were still observed. Nematode parasites were found in $17 \%$ of the fish stomachs sampled in Porirua Harbour and an unidentified parasite spp. was found on the gills of one female speckled sole (Table 7; Appendix C). formal identification of the gill leech found in this present study was not determined. Skin abnormalities were observed in 3 flatfish species (Appendix C).

\section{Fish tagging}

A total of $n=69$ fishes were tagged over 8 sites during a 4-month period (Figure 5: Appendix B). However, tagged fish were unable to be recovered so conclusions were left undetermined. The shortage of data needed to answer these questions simply highlights a need for larger sample sizes that could not have been collected within the limitations of this thesis.

\section{Heavy metal concentrations in flatfish}

Flatfish included in heavy metal analysis were yellow belly flounder $n=11$ and sand flounder $n=5$, which were pooled into one category 'flatfish' to increase the sample size. Speckled sole $(n=10)$ were excluded from heavy metal analysis due to tissue samples being pooled into $n=1$ for muscle and liver samples to meet the minimum requirements of the ICPMS ( $0.5 \mathrm{~g}$ of tissue).

\section{Copper (Cu)}

A negative relationship was found between $T L$ and weight and $\mathrm{Cu}$ levels in flatfish muscle (Figure 12a,c; Table 9), but there was no relationship between either measure of size and Cu levels in liver tissue (Figure 12b,d; Table 9). Cu levels in liver tissue were 5-times higher than muscle tissue averaging at $1.295 \mathrm{mg} / \mathrm{kg} w \cdot w$ (one-way ANOVA: $F_{1,104}=97.64, p=<0.001$ ) (Figure 13; Table 8). 
a)

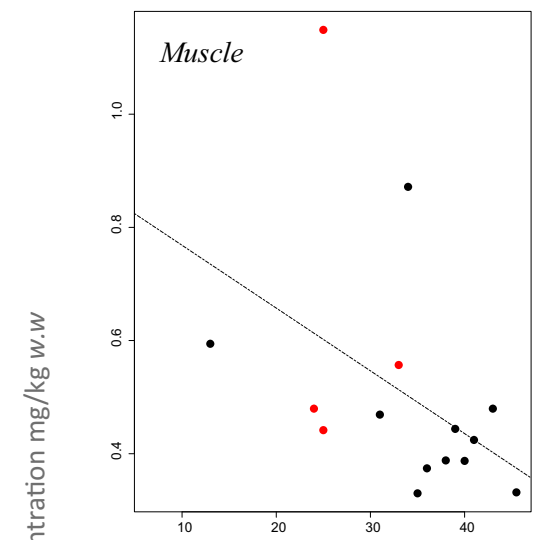

Total Length $(\mathrm{cm})$

b)

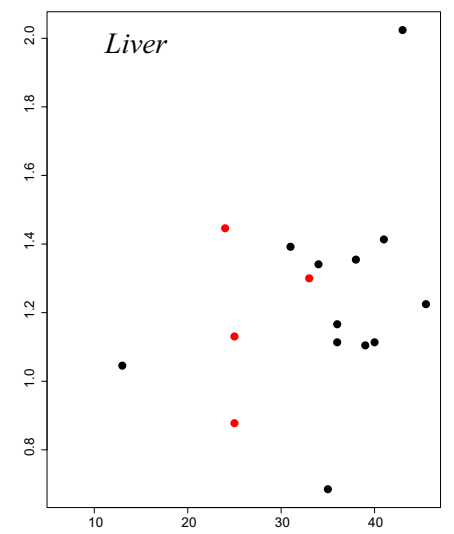

d)

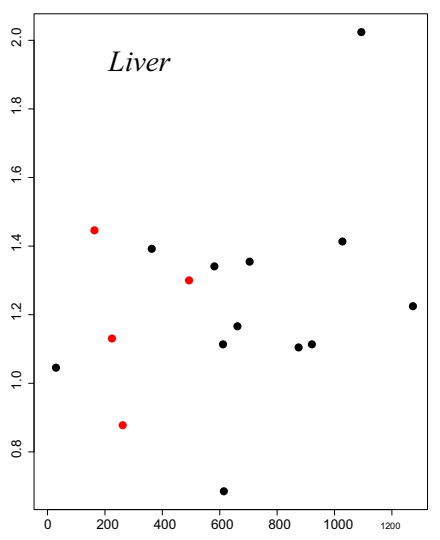

Weight (g)

Figure 12: The relationship between Cu concentrations $(\mathrm{mg} / \mathrm{kg} \mathrm{w} \cdot \mathrm{w})$ in the muscle and liver tissue of flatfish with Total Length $(\mathrm{cm})$ and weight $(\mathrm{g})$ as the covariate. Red represents males and black indicates females. 
Table 8. Mean concentrations ( $\mathrm{mg} / \mathrm{kg} \mathrm{w} . \mathrm{w}$ ) of metals \pm standard error in the tissue of flatfish (yellow belly flounder and sand flounder), rig shark and rays (short tailed stingray and eagle ray) caught in Porirua Harbour in 2018.

\begin{tabular}{|c|c|c|c|c|c|c|}
\hline Species & Sample size & Tissue & $\mathrm{Cu}$ & $\mathrm{Zn}$ & $\mathrm{Pb}$ & $\mathrm{Hg}$ \\
\hline \multirow[t]{4}{*}{ Flatfish } & 16 & Muscle & $0.20 \pm$ & $3.00 \pm$ & $0.01 \pm$ & $0.03 \pm$ \\
\hline & & & 0.314 & 1.023 & 0.004 & 0.050 \\
\hline & & Liver & $1.43 \pm$ & $18.83 \pm$ & $0.03 \pm$ & $0.06 \pm$ \\
\hline & & & 0.802 & 4.734 & 0.010 & 0.101 \\
\hline \multirow[t]{4}{*}{ Rig shark } & 21 & Muscle & $0.17 \pm$ & $2.49 \pm$ & $0.01 \pm 0.0203$ & $0.23 \pm$ \\
\hline & & & 0.090 & 0.6215 & & 0.1867 \\
\hline & & Liver & $0.97 \pm$ & $4.88 \pm 2.05$ & $0.03 \pm 0.017$ & $0.07 \pm$ \\
\hline & & & 0.343 & & & 0.0492 \\
\hline \multirow{3}{*}{$\begin{array}{l}\text { Rays * not } \\
\text { included in linear } \\
\text { models }\end{array}$} & 5 & Muscle & $0.13 \pm$ & $7.73 \pm 1.77$ & $0.1 \pm 0.07$ & $0.1 \pm 0.05$ \\
\hline & & & 0.24 & & & \\
\hline & & Liver & $N / A$ & $N / A$ & $N / A$ & $N / A$ \\
\hline
\end{tabular}

Table 9: linear model results for heavy metals $(\mathrm{Cu}, \mathrm{Zn}, \mathrm{Pb}, \mathrm{Hg})$ in flatfish tissue (muscle and liver) with Total Length (cm) and weight (g) as the covariate. Statistically significant results $p=<0.05$ indicated by*

\begin{tabular}{|c|c|c|c|c|}
\hline & $\begin{array}{l}\text { Weight } \\
\text { (g) }\end{array}$ & & $\begin{array}{c}\text { Total } \\
\text { Length } \\
(\mathrm{cm})\end{array}$ & \\
\hline & $r^{2}$ & $\mathrm{p}$-value & $r^{2}$ & $p$-value \\
\hline $\begin{array}{l}\text { Muscle } \\
\mathrm{Cu}\end{array}$ & 0.1731 & $0.0389 *$ & 0.1865 & $0.04487^{*}$ \\
\hline $\begin{array}{l}\text { Liver } \\
\mathrm{Cu}\end{array}$ & 0.1201 & 0.1885 & 0.1108 & 0.2077 \\
\hline $\begin{array}{l}\text { Muscle } \\
\text { Zn }\end{array}$ & 0.1541 & 0.1325 & 0.1746 & 0.1073 \\
\hline $\begin{array}{l}\text { Liver } \\
\text { Zn }\end{array}$ & 0.001505 & 0.8866 & 0.09665 & 0.2412 \\
\hline $\begin{array}{l}\text { Muscle } \\
\mathrm{Pb}\end{array}$ & 0.1118 & 0.2056 & 0.09665 & 0.2412 \\
\hline $\begin{array}{l}\text { Liver } \\
\mathrm{Pb}\end{array}$ & 0.05735 & 0.3717 & 0.05811 & 0.3684 \\
\hline $\begin{array}{l}\text { Muscle } \\
\mathrm{Hg}\end{array}$ & 0.67 & $0.0001324 *$ & 0.67 & $0.000749 *$ \\
\hline $\begin{array}{l}\text { Liver } \\
\text { Hg }\end{array}$ & 0.76 & $<0.005^{*}$ & 0.74 & $0.005851^{*}$ \\
\hline
\end{tabular}


Cu)

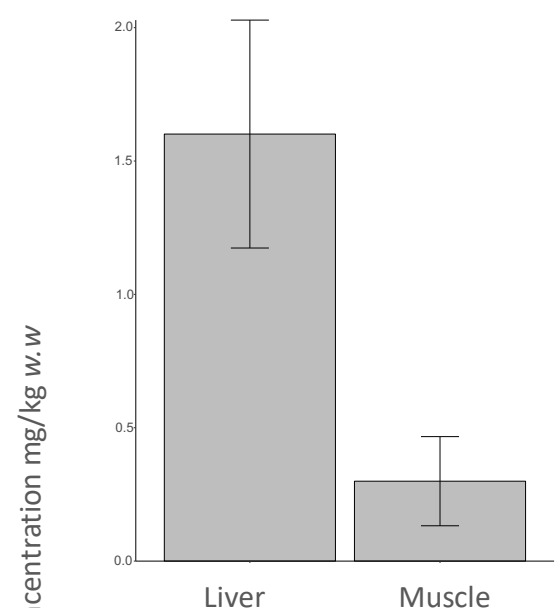

$\mathrm{Pb})$

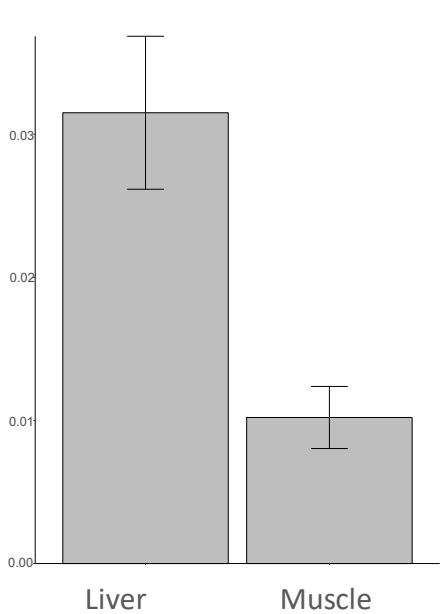

Zn)

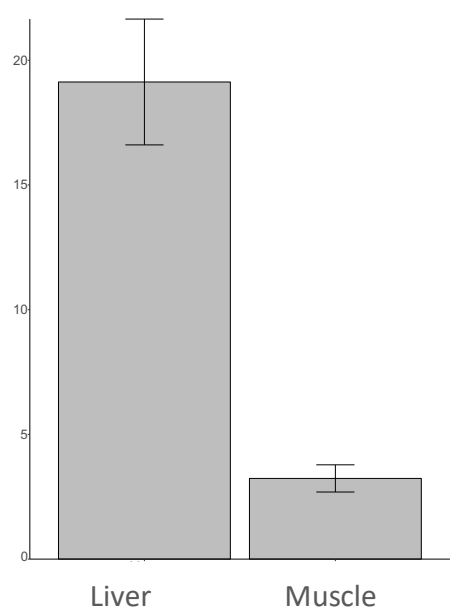

Hg)

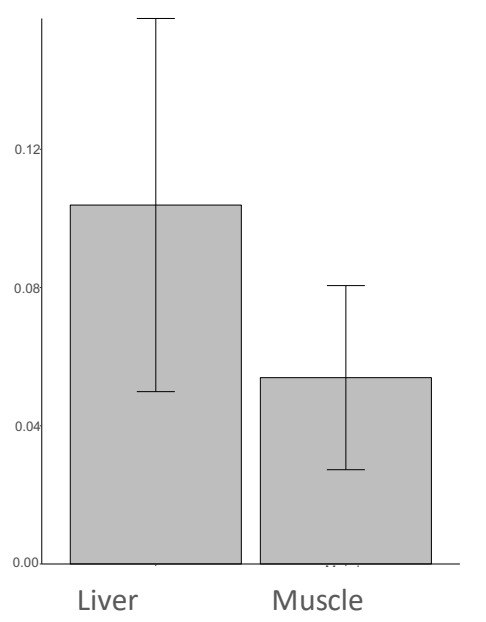

Tissue

Figure 13: Bar chart showing heavy metal concentrations $(\mathrm{Cu}, \mathrm{Zn}, \mathrm{Pb}, \mathrm{Hg})$ in flatfish tissue (muscle and liver) caught in Porirua Harbour in 2018. Error bars represent standard errors.

$\operatorname{Zinc}(Z n)$

No significant relationship was found between TL (or weight) and Zn levels in muscle and liver tissue in flatfish (Figure 14; Table 9). However, liver tissue had Zn concentrations 4-times higher than muscle tissue (one-way ANOVA: $F_{1,104}=141.35, p=<0.001$ ), averaging at 12.81 $\mathrm{mg} / \mathrm{kg}$ w.w (Figure 13; Table 8). 
a)

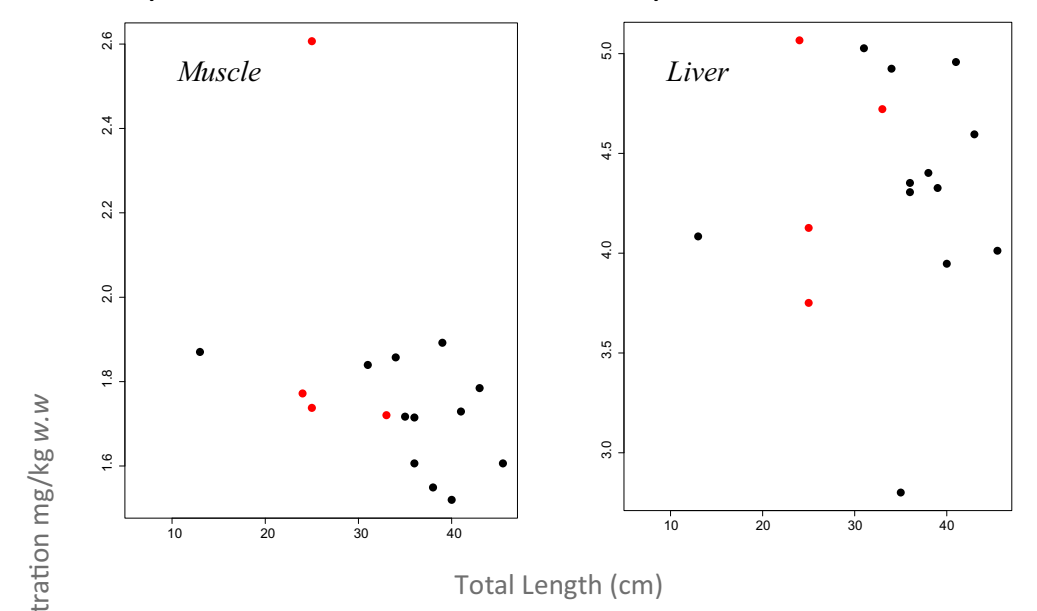

c)

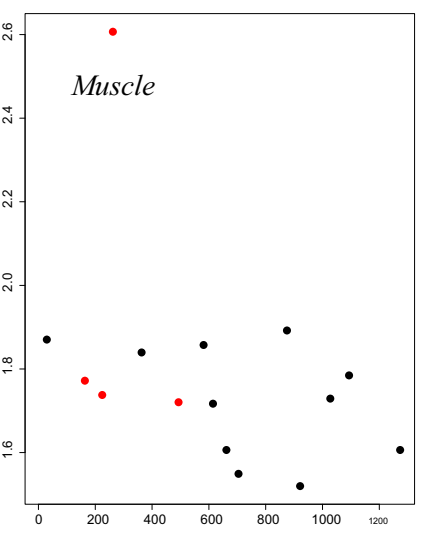

d)

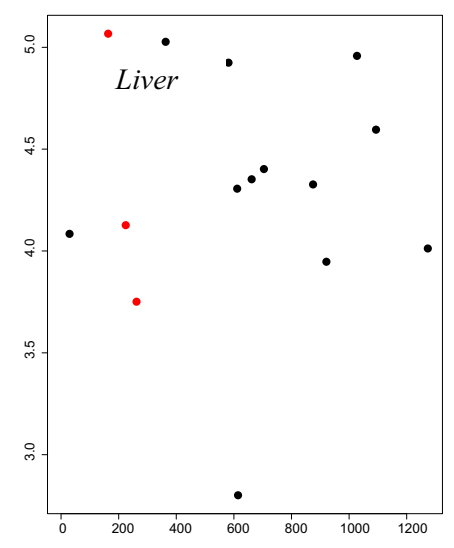

Weight (g)

Figure 14: The relationship between $\mathrm{Zn}$ concentrations $(\mathrm{mg} / \mathrm{kg} w . w)$ in the muscle and liver tissue of flatfish with Total Length $(\mathrm{cm})$ and weight $(\mathrm{g})$ as the covariate. Red represents males and black indicates females.

Lead $(P b)$

No significant relationship was found between $\mathrm{TL}$ (or weight) and $\mathrm{Pb}$ levels in muscle and liver tissue in flatfish (Figure 15; Table 9). Pb levels were significantly different across muscle and liver tissue (one-way ANOVA: $F_{1,104}=61.91, p=<0.001$ ), but were relatively low in concentration averaging 0.01 and $0.03 \mathrm{mg} / \mathrm{kg} w . w$ respectively (Figure 13; Table 8). 
a)

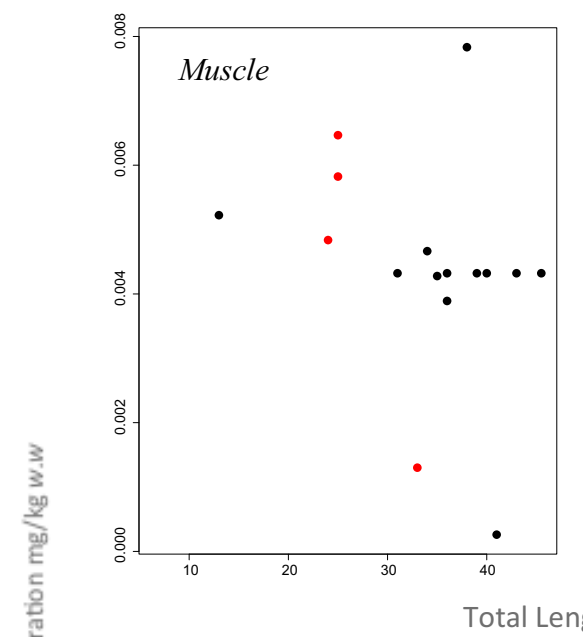

c)

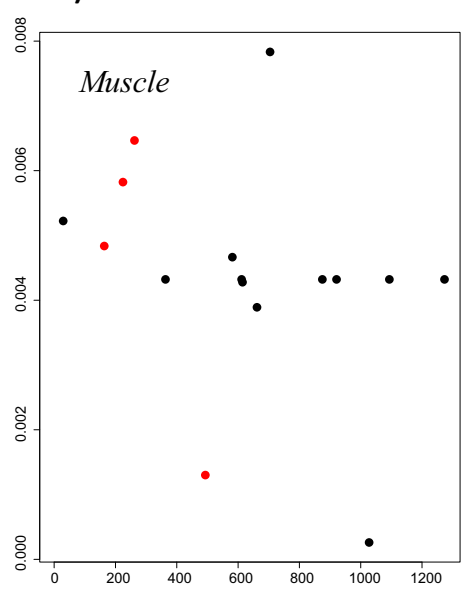

b)

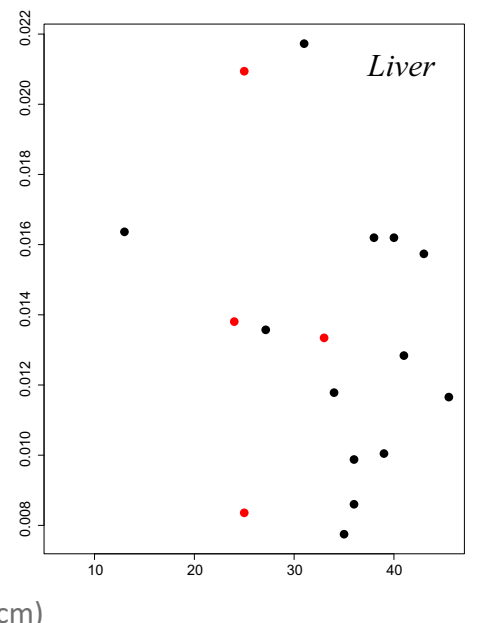

d)

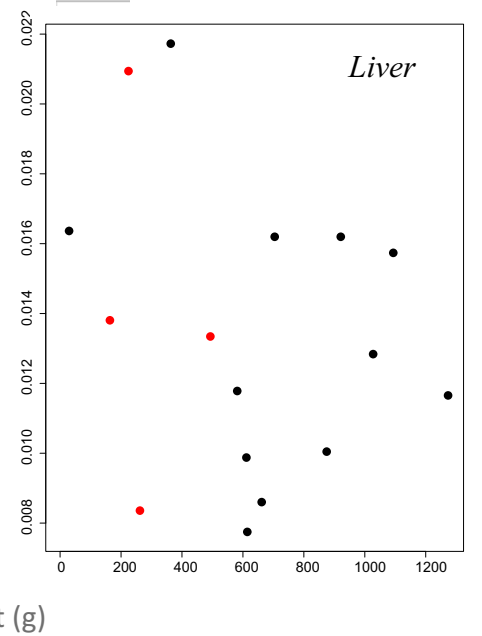

Figure 15: The relationship between $\mathrm{Pb}$ concentrations $(\mathrm{mg} / \mathrm{kg} w . w)$ in the muscle and liver tissue of flatfish with Total Length $(\mathrm{cm})$ and weight $(\mathrm{g})$ as the covariate. Red represents males and black indicates females.

\section{$\operatorname{Mercury}(\mathrm{Hg})$}

A significant $3^{\text {rd }}$-order exponential relationship was found between $\mathrm{TL}$ and $\mathrm{Hg}$ levels in muscle and liver tissue in flatfish (Figure 16a, b; Table 9). A significant linear relationship was found between flatfish weight and $\mathrm{Hg}$ levels in muscle tissue, whereas weight had $2^{\text {nd }}$-order polynomial relationship with $\mathrm{Hg}$ levels in liver (Figure 16c, d; Table 9). All models identify longer and heavier flatfish having higher $\mathrm{Hg}$ concentration with low accumulation up until $30 \mathrm{~cm} / 600 \mathrm{~g}$ in liver tissue respectively. There was no significant difference between muscle and liver Hg concentrations (one-way ANOVA: $F_{1,104}=71.94, p=0.134$ ) (Figure 13; Table 8). 
a)

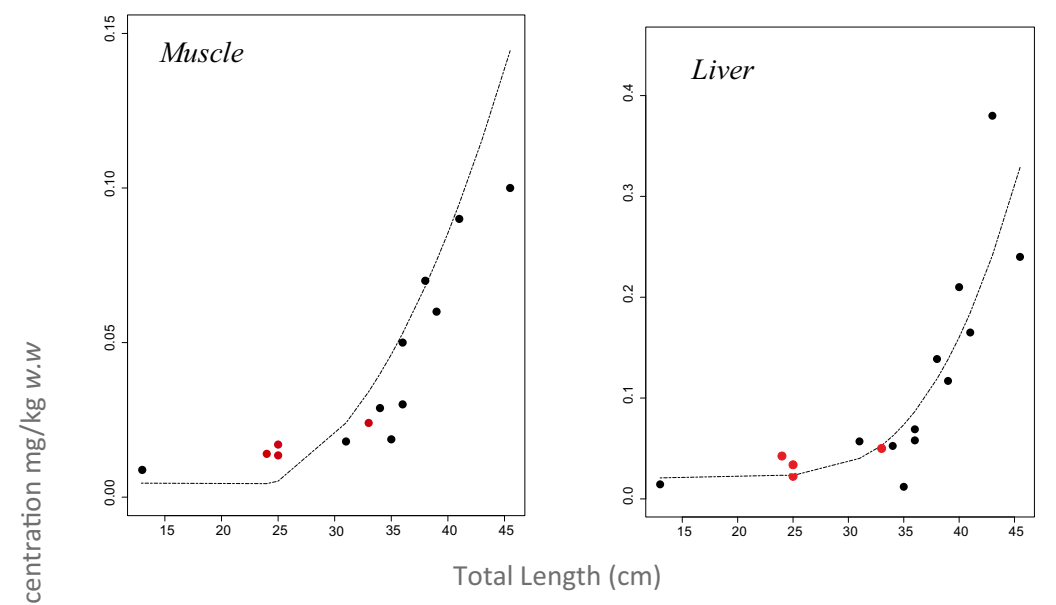

c)

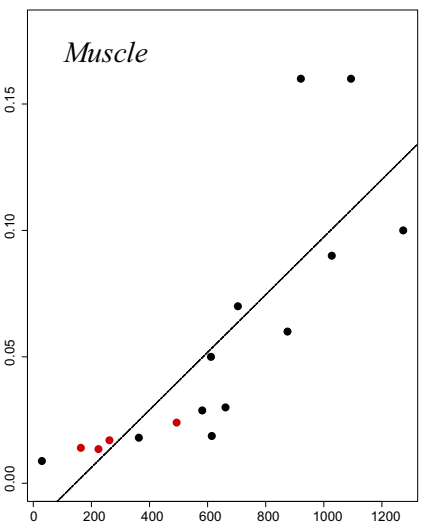

d)

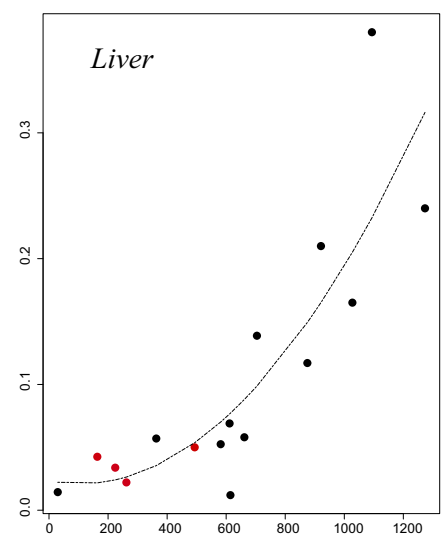

Weight (g)

Figure 16: The relationship between $\mathrm{Hg}$ concentrations $(\mathrm{mg} / \mathrm{kg} \mathrm{w} . w)$ in the muscle and liver tissue of flatfish with Total Length $(\mathrm{cm})$ and weight $(\mathrm{g})$ as the covariate. Red represents males and black indicates females.

\section{Heavy metal interactions in flatfish}

Significant, positive, linear relationships were found between $\mathrm{Cu}$ and $\mathrm{Zn}$ levels in the muscle $(r=0.66, n=17, p=<0.001)$ and liver tissue $(r=0.37, n=16, p=0.012$ (Figure 17a,b). There were also significant positive, linear relationships between liver $\mathrm{Cu}$ levels and muscle $\mathrm{Hg}$ ( $r=$ 0.27, $n=16, p=0.0396)$, liver $\mathrm{Hg}(r=0.51, n=16, p=0.002)$, and liver $\mathrm{Zn}(r=0.37, n=16, p=$ 0.01237) (Figure 17c,d). No other significant relationships among metals in the two tissue types were observed (Appendix E). 
a)

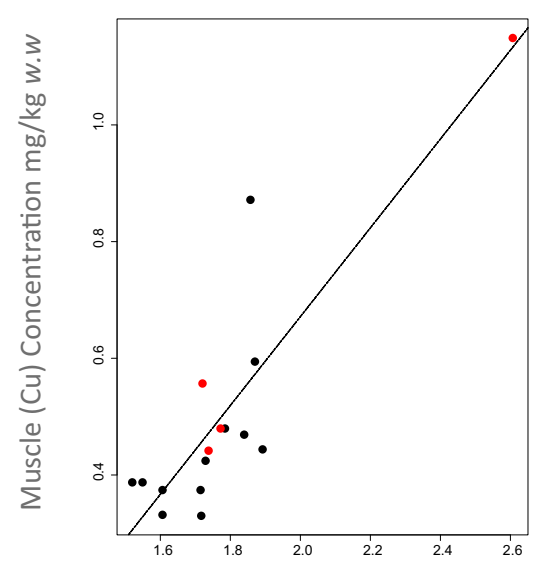

Muscle (Zn) Concentration mg/kg w.w

c)

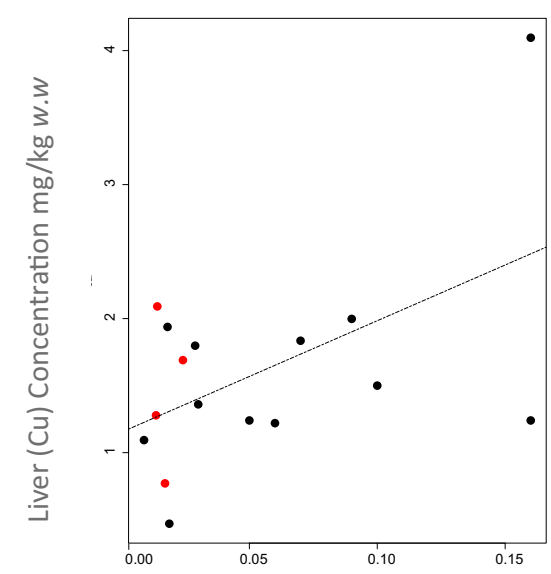

Muscle (Hg) Concentration mg/kg w.w b)

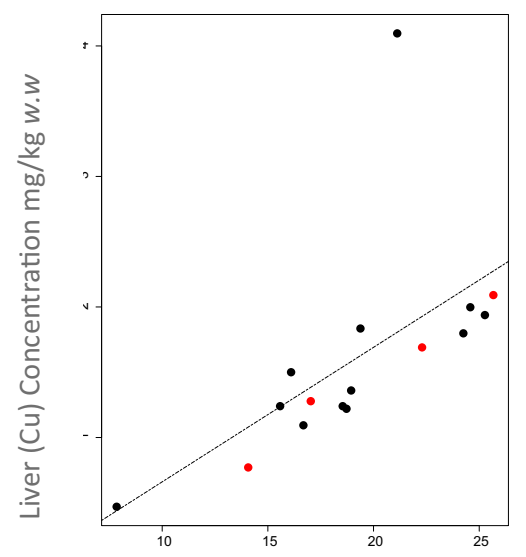

Liver (Zn) Concentration mg/kg w.w

d)

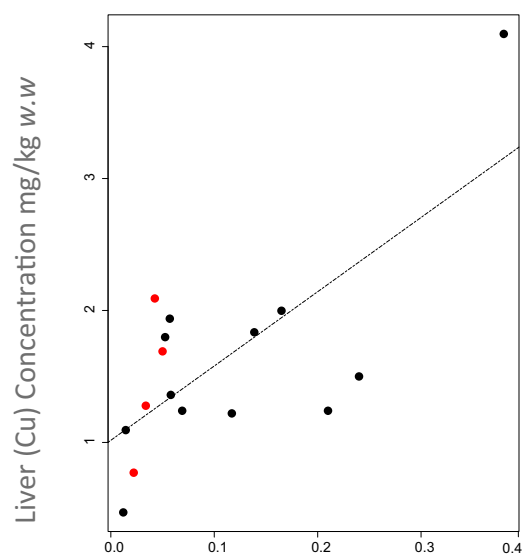

Liver $(\mathrm{Hg})$ Concentration $\mathrm{mg} / \mathrm{kg}$ w.w

Figure 17: The relationship between muscle Cu concentration and a) muscle $\mathrm{Hg}$, b) Liver $\mathrm{Hg}$, and the relationship between liver $\mathrm{Cu}$ concentration and c) muscle $\mathrm{Hg}$, b) liver $\mathrm{Hg}$ in flatfish. Results reported in $\mathrm{mg} / \mathrm{kg} \mathrm{w} . \mathrm{w}$. Red represents males and black indicates females.

Heavy metal concentration in Rig Shark

\section{Copper (Cu)}

A weak negative relationship was found between $T L$ and $\mathrm{Cu}$ levels in muscle tissue (Figure 18a), but not in liver tissue in rig shark (Figure 18b, Table 10). No significant relationship was found between rig shark weight and $\mathrm{Cu}$ levels in muscle and liver tissue (Figure 18c,d; Table 
10). Liver tissue had $\mathrm{Cu}$ concentration 6-times that of muscle tissue (one-way ANOVA: $\mathrm{F}_{1,40}=$ 76.99, $\mathrm{p}<0.005$ ) (Figure 19; Table 8).

a)

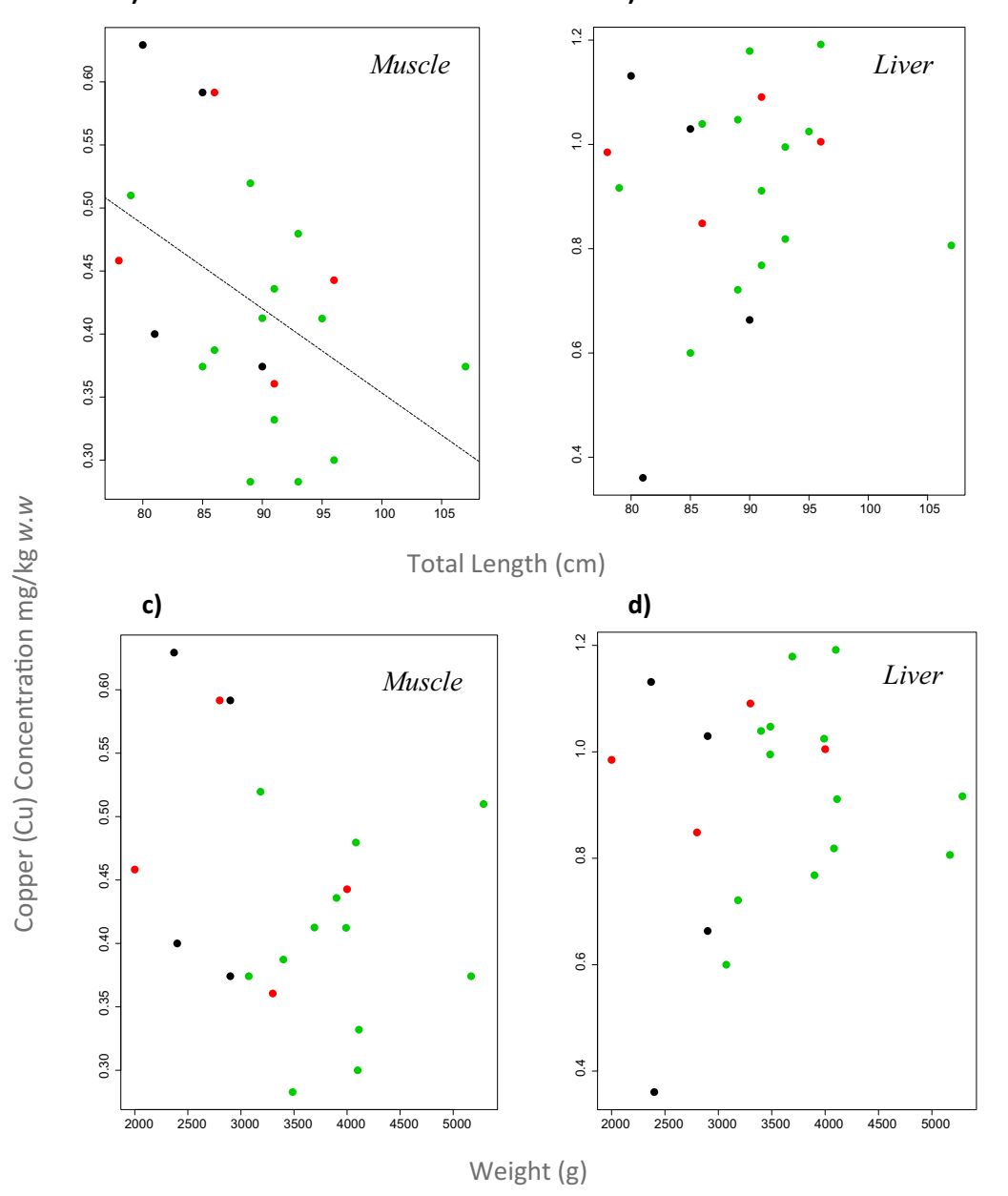

Figure 18: The relationship between $\mathrm{Cu}$ concentrations $(\mathrm{mg} / \mathrm{kg} \mathrm{w} . \mathrm{w})$ in the muscle and liver tissue of rig shark with Total Length $(\mathrm{cm})$ and weight $(\mathrm{g})$ as the covariate. Red is pre-ovulatory females, green is pregnant females and black is males. 
Table 10: Linear model results for heavy metals ( $\mathrm{Cu}, \mathrm{Zn}, \mathrm{Pb}, \mathrm{Hg}$ ) in rig shark tissue (muscle and liver) with Total Length (cm) and weight $(\mathrm{g})$ as the covariate. Statistically significant results $p=<0.05$ indicated by*

\begin{tabular}{lllll} 
& Weight $(\mathrm{g})$ & & Total Length $(\mathrm{cm})$ \\
\hline Muscle $\mathrm{Cu}$ & 0.241 & $\mathrm{p}$-value & $\mathrm{r}^{2}$ & $\mathrm{p}$ value \\
\hline Liver $\mathrm{Cu}$ & 0.01098 & 0.742 & 0.0734 & $0.038^{*}$ \\
\hline Muscle Zn & 0.03181 & 0.6513 & 0.00832 & 0.6942 \\
\hline Liver Zn & $<0.001$ & 0.4392 & 0.1119 & 0.1384 \\
\hline Muscle Pb & 0.0265 & 0.9943 & 0.001941 & 0.8496 \\
& PRE-OVULATORY & & $<0.001$ & 0.4339 \\
& FEMALE: 0.48 & 0.02077 & FEMALE: 0.43 & 0.01912 \\
\hline Liver Pb & 0.0009168 & 0.8963 & 0.01505 & 0.5963 \\
\hline Muscle $\mathrm{Hg}$ & 0.05858 & 0.2905 & 0.119 & 0.1256 \\
\hline Liver $\mathrm{Hg}$ & 0.273 & $0.011^{*}$ & 0.1041 & $0.015^{*}$ \\
\hline
\end{tabular}

$\mathrm{Cu})$

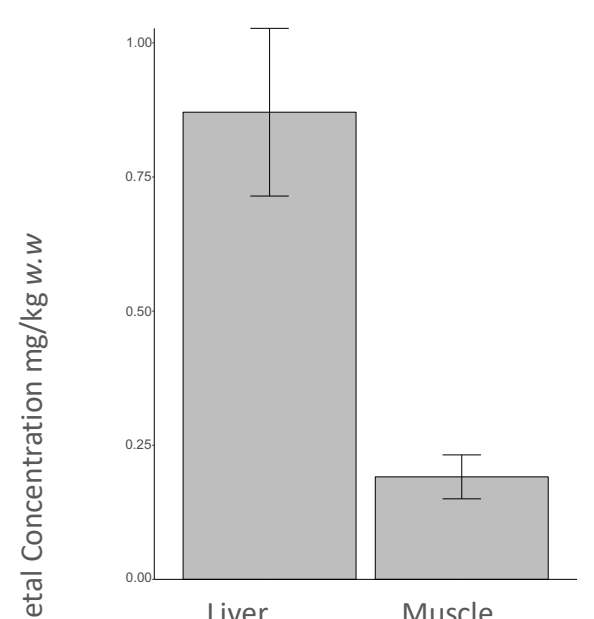

Liver

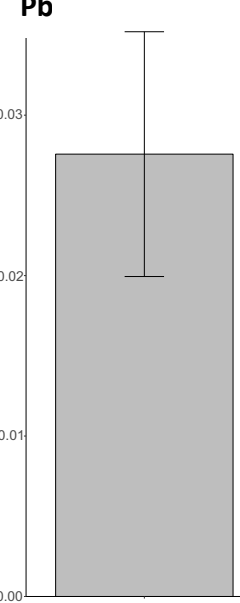

Liver
Muscle

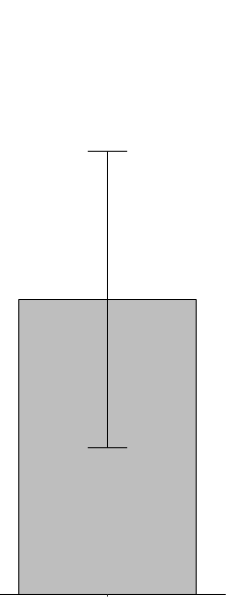

Muscle
$\mathrm{Zn)}$

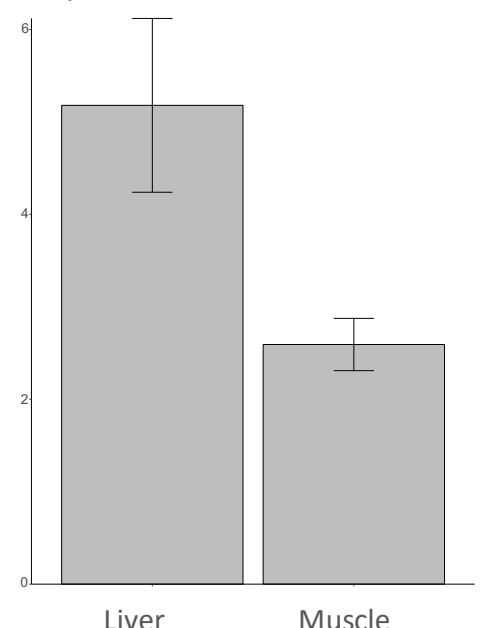

$\mathrm{Hg)}$

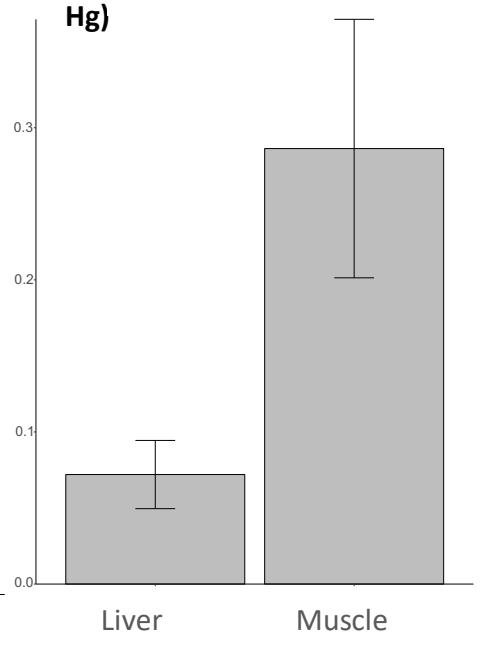

Tissue Type

Figure 19: Bar chart showing heavy metal ( $\mathrm{Cu}, \mathrm{Zn}, \mathrm{Pb}, \mathrm{Hg}$ ) concentration (mg/kg w.w) in rig shark tissue (muscle and liver) caught in Porirua Harbour in 2018. Error bars represent standard errors. 
No significant relationship was found between $\mathrm{TL}$, or weight, and $\mathrm{Zn}$ levels in muscle and liver tissue in rig shark (Figure 20, Table 10). Liver concentration was 2-times higher than muscle concentration (one-way ANOVA: $F_{1,40}=30.22, p=<0.005$ ) averaging at $5 \mathrm{mg} / \mathrm{kg} w \cdot w$ (Figure 19; Table 8).

a)

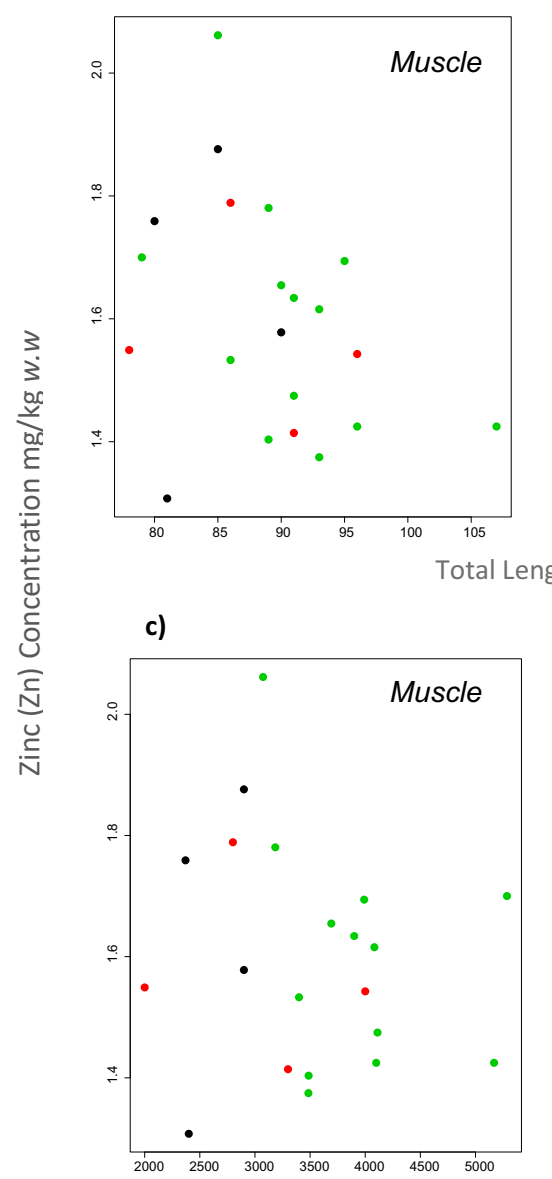

b)

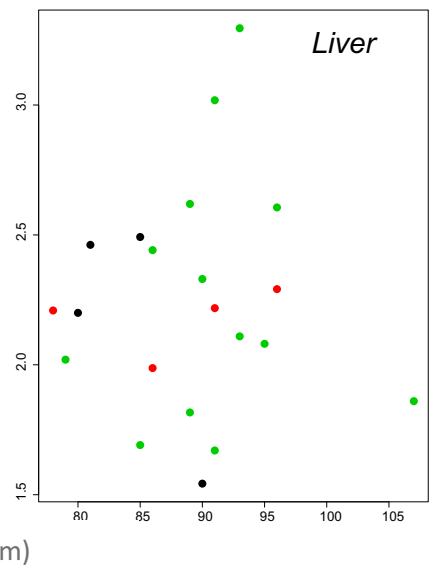

d)

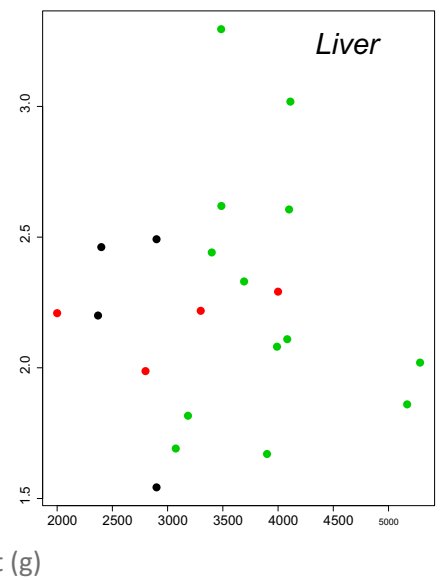

Figure 20: The relationship between $\mathrm{Zn}$ concentrations $(\mathrm{mg} / \mathrm{kg} w . w)$ in the muscle and liver tissue of rig shark with Total Length $(\mathrm{cm})$ and weight $(\mathrm{g})$ as the covariate. Red is pre-ovulatory females, green is pregnant females and black is males

Lead (Pb)

A weak linear relationship was found between $\mathrm{TL}$, and weight, and $\mathrm{Pb}$ levels in muscle tissue in pre-ovulatory rig shark females (Figure 21a,d; Table 10). Muscle Pb concentration in rig 
shark was also influenced by maturation status (Kruskall -Wallis: $p=0.0068$ ), with preovulatory females having $\mathrm{Pb}$ muscle concentration 4-times higher than pregnant females and males (Figure 22; Table 11). There was no difference in Pb concentration across tissue types (Kruskall- Wallis: $p=0.1176$; Figure 19$)$. $\mathrm{Pb}$ concentration in muscle tissue of males and pregnant rig shark were not significant for TL and weight (Figure 21b, d; Table 10).

a)

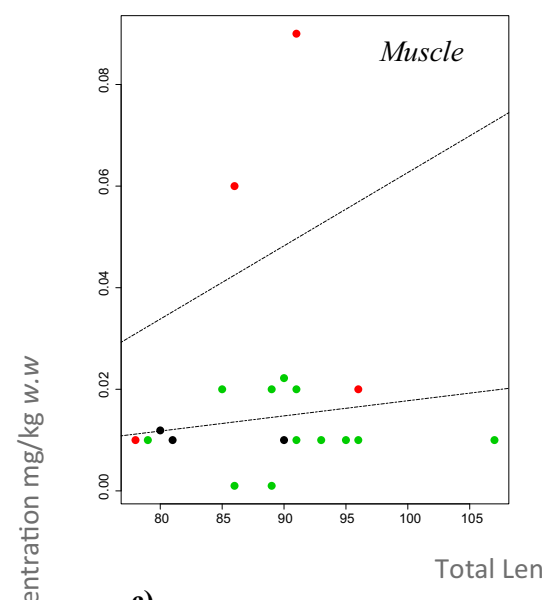

c)

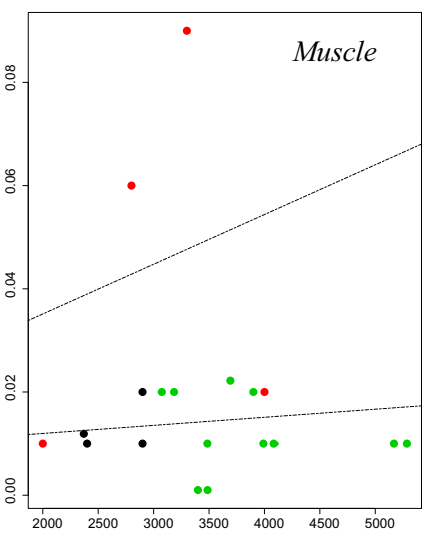

b)

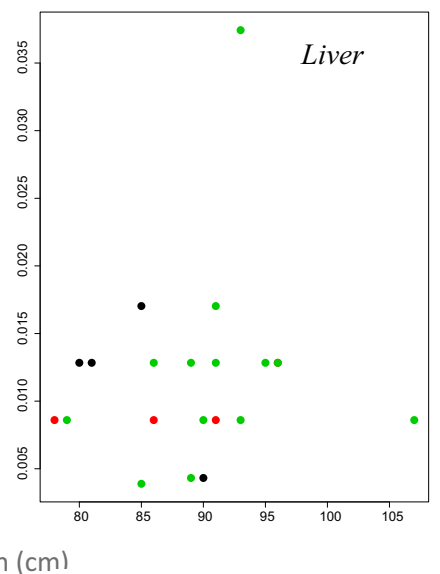

d)

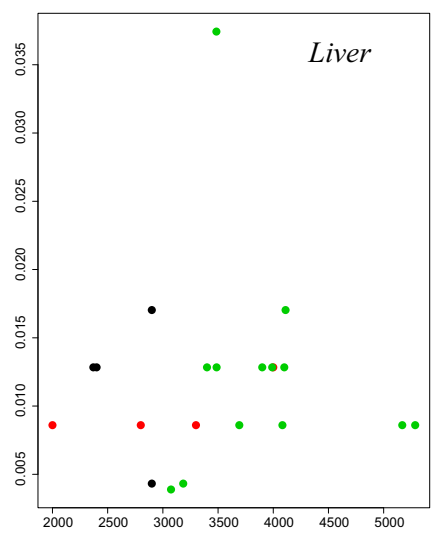

Weight (g)

Figure 21: The relationship between Pb concentrations $(\mathrm{mg} / \mathrm{kg} w . w)$ in the muscle and liver tissue of rig shark with Total Length $(\mathrm{cm})$ and weight $(\mathrm{g})$ as the covariate. Red is pre-ovulatory females, green is pregnant females and black is males. 


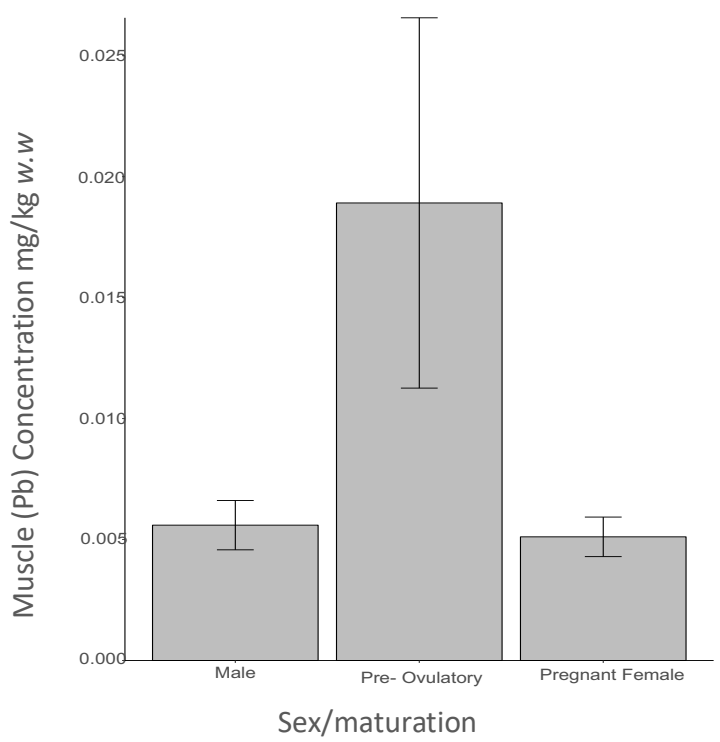

Figure 22: Barchart showing relationship between maturation/sex (male, pre-ovulatory female and pregnant female) and muscle Lead ( $\mathrm{Pb}$ ) concentration in rig shark caught from Porirua Harbour in 2018. Error bars represent standard errors.

Table 11: Table showing mean $\mathrm{Pb}$ concentrations (mg/kg w.w) \pm standard deviation in tissue (muscle and liver) of rig shark caught in Porirua Harbour in 2018.

\begin{tabular}{|c|c|c|c|c|c|c|c|}
\hline & $\begin{array}{l}\text { Maturation } \\
\text { Status }\end{array}$ & $N$ & Tissue & $\mathrm{Cu}$ & $\mathrm{Zn}$ & $\mathbf{P b}$ & $\mathrm{Hg}$ \\
\hline \multirow[t]{4}{*}{ Male } & 2 & 4 & Muscle & $0.26 \pm$ & $2.79 \pm$ & $0.01 \pm$ & $0.26 \pm$ \\
\hline & & & & 0.1304 & 0.7857 & 0.0048 & 0.0826 \\
\hline & & & Liver & $0.75 \pm$ & 5.45 & $0.03 \pm$ & $0.06 \pm$ \\
\hline & & & & 0.340 & \pm 1.771 & 0.0126 & 0.083 \\
\hline Pregnant & 5 & 13 & Muscle & $0.15 \pm$ & $2.61 \pm$ & $0.01 \pm$ & $0.24 \pm$ \\
\hline \multirow[t]{3}{*}{ Female } & & & & 0.0640 & 0.6468 & 0.0069 & 0.216 \\
\hline & & & Liver & $0.84 \pm$ & $4.45 \pm$ & $0.03 \pm$ & $0.07 \pm$ \\
\hline & & & & 0.325 & 2.469 & $0.02-$ & 0.0588 \\
\hline Pre- & 3 & 4 & Muscle & $0.2 \pm$ & 2.39 & $0.04 \pm$ & $0.16 \pm$ \\
\hline Ovulatory & & & & 0.092 & \pm 0.505 & 0.0404 & 0.043 \\
\hline \multicolumn{8}{|l|}{ Female } \\
\hline & & & Liver & $0.99 \pm$ & $4.9 \pm$ & $0.02 \pm$ & $0.04 \pm$ \\
\hline & & & & 0.1936 & 0.559 & 0.005 & 0.0168 \\
\hline
\end{tabular}


A weak, positive linear relationship was found between TL (and weight) and Hg levels in liver tissue of rig shark (Figure 23b,d; Table 10), but there was no relationship with muscle tissue (Figure 23a,c; Table 10). Hg levels in muscle tissue were 3-times higher than liver (one-way ANOVA: $F_{1,40}=25.87, p=<0.001$ ) (Figure 19). The mean $\mathrm{Hg}$ concentration was $0.23 \mathrm{mg} / \mathrm{kg}$ w.w, with 2 outliers being pregnant females with $\mathrm{Hg}$ concentrations of 0.73 and $0.84 \mathrm{mg} / \mathrm{kg}$ w.w (Figure 23a, c; Table 8).

a)

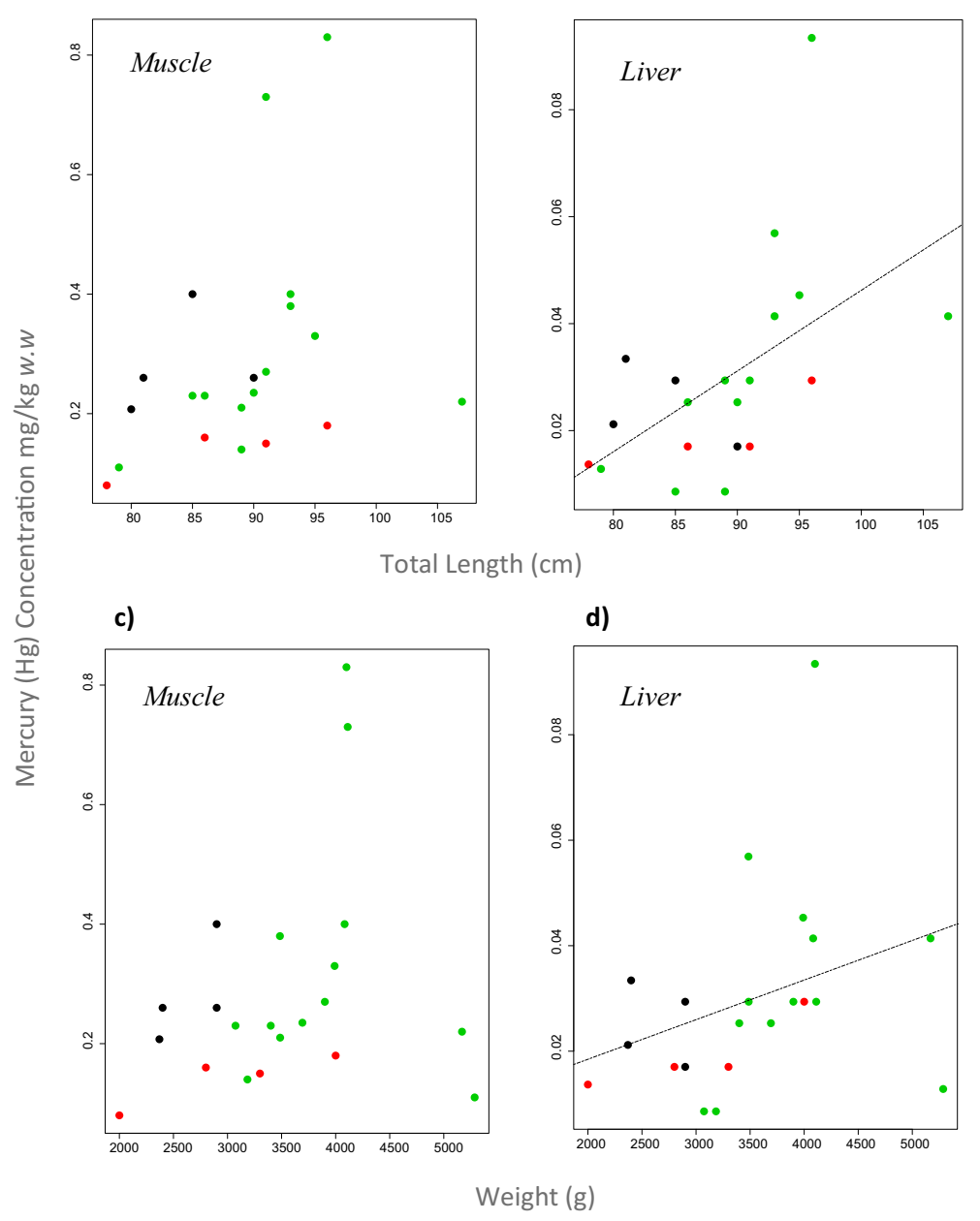

Figure 23: The relationship between $\mathrm{Hg}$ concentrations $(\mathrm{mg} / \mathrm{kg} \mathrm{w} . \mathrm{w})$ in the muscle and liver tissue of rig shark with Total Length $(\mathrm{cm})$ and weight $(\mathrm{g})$ as the covariate. Red is pre-ovulatory females, green is pregnant females and black is males. 
A positive linear relationship was found between $\mathrm{Zn}$ and $\mathrm{Cu}$ levels in muscle tissue of rig shark $(r=0.40, n=21, p=0.00226)$ (Figure 24a), between $P b$ and $Z n$ in liver tissue $(r=0.71, n=21$, $p=<0.05$ ) (Figure 24b), and between liver $\mathrm{Zn}$ and muscle $\mathrm{Hg}$ levels ( $r=0.27, n=21, p=0.015$ ) (Figure 24c). There was also a positive linear relationship between liver $\mathrm{Hg}$ and Liver $\mathrm{Pb}$ ( $\mathrm{r}=$ $0.22, n=21, p=0.03)$ (Figure 24d), liver $Z n(r=22, n=21, p=0.03)$ (Figure 24e), but a negative relationship between liver $\mathrm{Hg}$ and muscle $\mathrm{Zn}$ levels ( $r=0.21, \mathrm{n}=21, \mathrm{p}=0.036$ ) (figure24f). No other significant relationships were observed (Appendix E).

a)

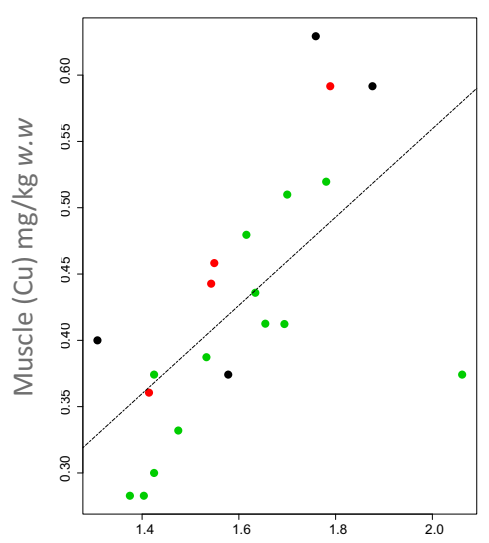

Muscle (Zn) mg/kg w.w

d)

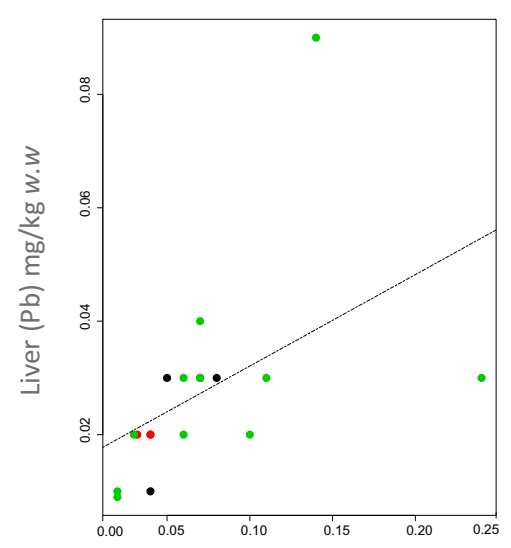

Liver (Hg) mg/kg w.w b)

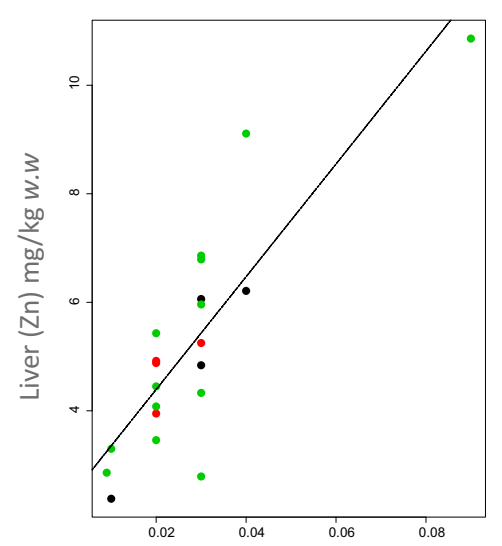

Liver $(\mathrm{Pb}) \mathrm{mg} / \mathrm{kg}$ w.w

e)

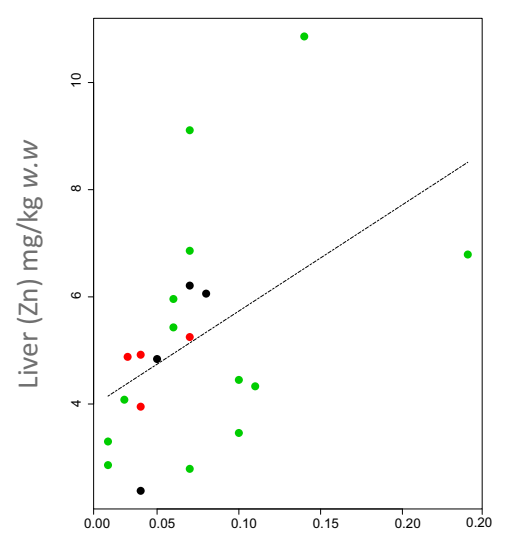

Liver (Hg) mg/kg w.w c)

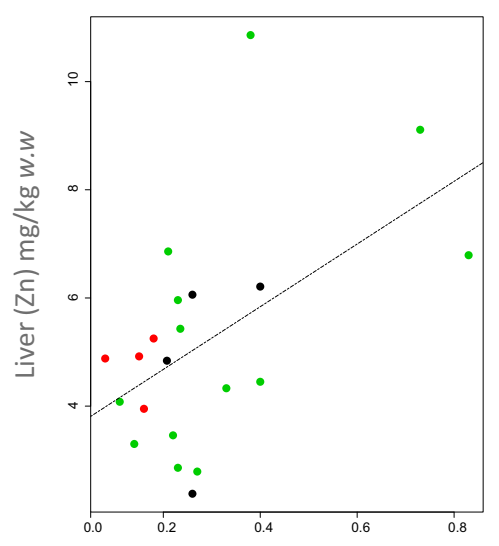

Muscle (Hg) mg/kg w.w

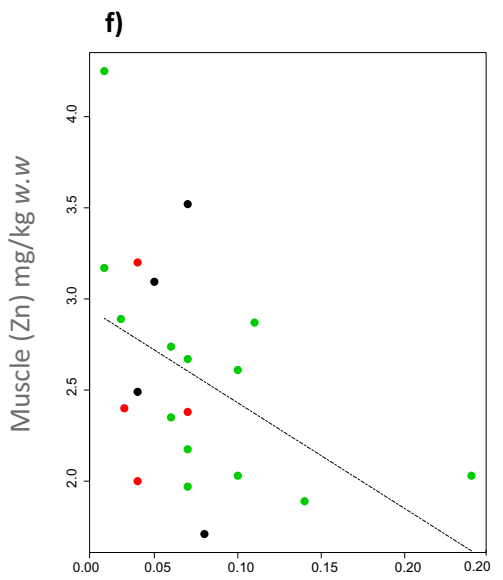

Liver (Hg) mg/kg w.w

Figure 24: The relationship between the levels of a) muscle $\mathrm{Cu}$ and muscle $\mathrm{Zn}, \mathrm{b}$ ) liver $\mathrm{Zn}$ and liver $\mathrm{Pb}, \mathrm{c}$ ) liver $\mathrm{Zn}$ and muscle $\mathrm{Hg}$, d) Liver $\mathrm{Pb}$ and Liver $\mathrm{Hg}$, e) liver $\mathrm{Zn}$ and liver $\mathrm{Hg}$, f) muscle $\mathrm{Zn}$ and liver $\mathrm{Hg}$ in rig shark. Green = pregnant females, red = pre-ovulatory females, black= males. Results reported in $\mathrm{mg} / \mathrm{kg} w . w$. 


\section{Taxa comparisons}

The order of heavy metal concentration in flatfish tissue was $\mathrm{Zn}>\mathrm{Cu}>\mathrm{Hg}>\mathrm{Pb}$ for both muscle and liver, whereas the order of heavy metal concentration in rig shark was $\mathrm{Zn}>\mathrm{Hg}>\mathrm{Cu}>\mathrm{Pb}$ in muscle and $\mathrm{Zn}>\mathrm{Cu}>\mathrm{Hg}>\mathrm{Pb}$ in liver tissue.

Concentration of $\mathrm{Cu}$ in muscle tissue was similar across taxa (one-way ANOVA: $F_{2,34}=1.42, p$ $=0.257)$ and were in the range of $0.09-1.32 \mathrm{mg} / \mathrm{kg}$ with an average value of $0.18 \pm 0.22$. Cu concentrations in the liver tissue were higher in flatfish (one-way ANOVA: $F_{1,102}=12.23, p=$ $0.000698)$, and were in the range of 0.14-4.09 with average value of $1.30 \pm 0.29$, and $0.13-$ 1.39. Cu liver concentrations in rig shark were in the range of $0.13-1.39$, with an average value of $0.97 \pm 0.34$ (Figure 25; Table 12).

Zn concentrations in muscle tissue were similar across taxa (one-way ANOVA: $F_{2,34}=2.801, p$ $=0.074)$, ranging from 1.71-6.795, with a mean value of $2.87 \pm 0.87 \mathrm{mg} / \mathrm{kg}$. Zn concentration in liver tissue were higher in flatfish (one-way ANOVA: $F_{1,102}=143.72, p=<0.005$ ), ranging from 14.07-22.3, with a mean value of $12.81 \pm 8.0$. Rig shark ranged from $3.30-10.86$, with a mean value of $4.88 \pm 2.07$ (Figure 25 ; Table 12).

Concentration of $\mathrm{Hg}$ in muscle tissue was different across taxa (One-way ANOVA: $F_{2,34}=7.18$, $\mathrm{p}=0.008594)$, with rig shark having a muscle $\mathrm{Hg}$ concentrations 4-times higher than flatfish. Flatfish muscle $\mathrm{Hg}$ levels and were in the range of 0.008-0.2 with a mean value of $0.03 \pm 0.05$ $\mathrm{mg} / \mathrm{kg}$. Rig shark were in the range of $0.14-0.83$ with a mean value of $0.23 \pm 0.19 \mathrm{mg} / \mathrm{kg} . \mathrm{Hg}$ concentrations in liver tissue were similar across taxa (one-way ANOVA: $F_{2,34}=0.89, p=0.42$ ), ranging from $0.01-0.24$ with a mean value of $0.06 \pm 0.08$ (Figure 25 ; Table 12 ).

Concentration of $\mathrm{Pb}$ in muscle tissue was similar across taxa (one-way ANOVA: $F_{2,34}=0.67, p$ $=0.41424)$ and were in the range of $0.001-0.06 \mathrm{mg} / \mathrm{kg}$ with an average value of $1.01 \pm 0.02$. $\mathrm{Pb}$ concentrations in liver tissue were similar across taxa (one-way ANOVA: $F_{2,34}=0.52, p=$ 0.597 ), ranging from $0.009-0.05$ with a mean value of $0.03 \pm 0.014$ (Figure 25; Table 12). 
Heavy metal concentrations in rays (eagle ray and short-tailed stingray) were determined through muscle tissue only, and were in the order of $\mathrm{Zn}>\mathrm{Cu}>\mathrm{Pb} / \mathrm{Hg}$. $\mathrm{Cu}$ in ray muscle tissue was similar to flatfish and rig shark, but $Z n$ was 3-times higher (one-way ANOVA: $F_{2,81}=16.24$, $\mathrm{p}<0.001$ ) and $\mathrm{Pb}$ was 10 -times higher than flatfish and rig shark (one-way ANOVA: $F_{2,81}=6.07$, $\mathrm{p}=0.004) . \mathrm{Hg}$ in ray muscle tissue were 3 -times higher than flatfish but 2-times lower than rig shark (one-way ANOVA: $F_{2,81}=6.61, p=0.002$ ) (Figure 25; Table 8).

Cu)

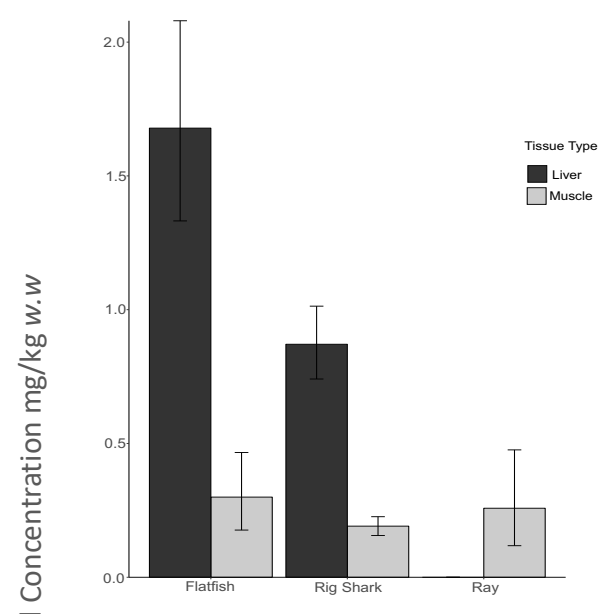

$\mathrm{Pb})$

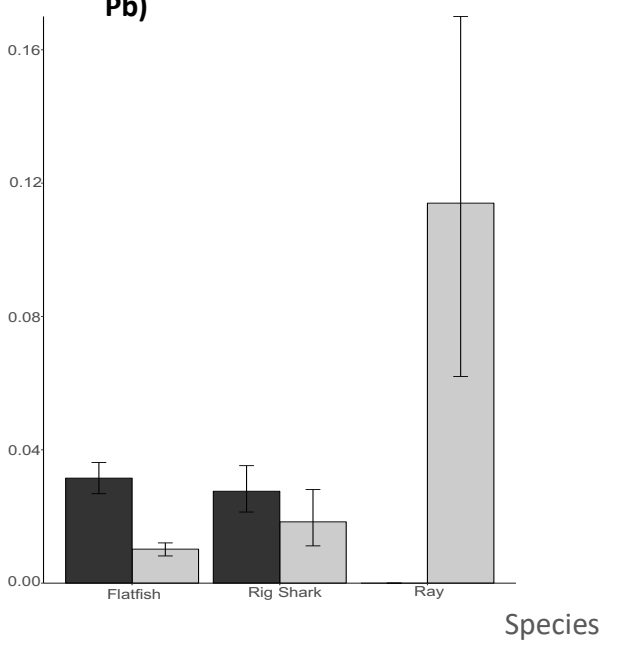

$\mathrm{Zn)}$

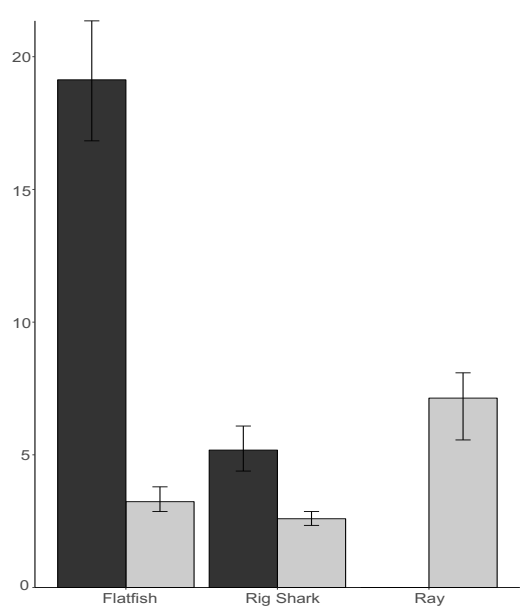

$\mathrm{Hg})$

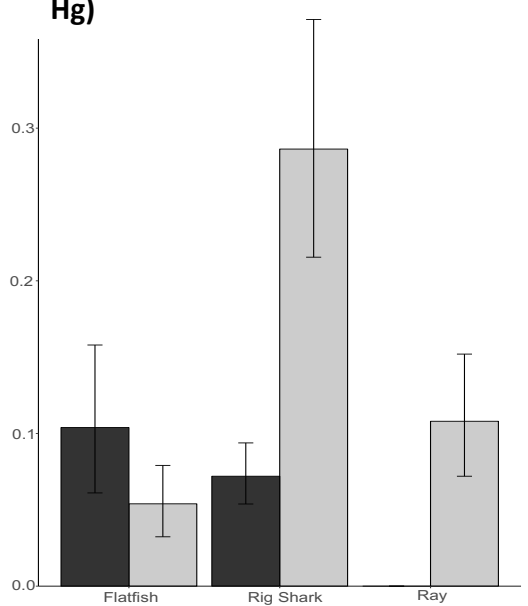

Figure 25: Barchart showing the relationship between heavy metals $(\mathrm{Cu}, \mathrm{Zn}, \mathrm{Pb}, \mathrm{Hg})$ in tissue (muscle and liver) of rig shark, rays (eagle ray and short-tailed stingray) and flatfish caught from Porirua Harbour in 2018. Error bars represent standard errors. 


\section{Taxa and sediment comparisons}

Both essential metals, $\mathrm{Cu}$ and $\mathrm{Zn}$, were found in higher concentration in sediment than in rays and rig shark tissue (one-way ANOVA: $F_{3,88}=16.94, p=<0.001 ; F_{3,88}=25.05, p=<0.001$ ) (Figure 26), but were not significantly different from concentrations found in flatfish liver (Tukey post hoc: $p=0.9104 ; p=0.363)$. Pb concentration in sediment was nearly 200-times higher than concentrations found in fish tissue (one-way ANOVA: $F_{3,88}=158.36, p=<0.001$ ), whereas $\mathrm{Hg}$ concentration in sediment averaged 5-times lower than rig and ray, and 3-times lower than flatfish (one-way ANOVA:3,88= 8.99, $p=0.003$ ) (Figure 26).

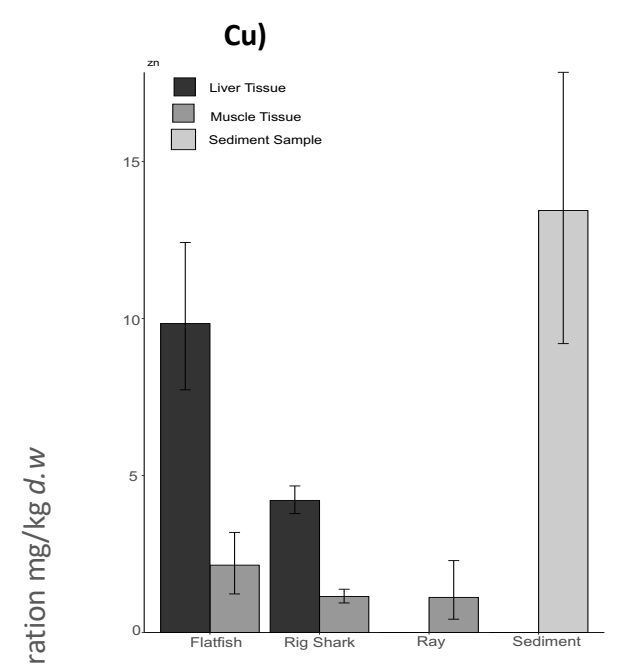

$\mathrm{Pb})$

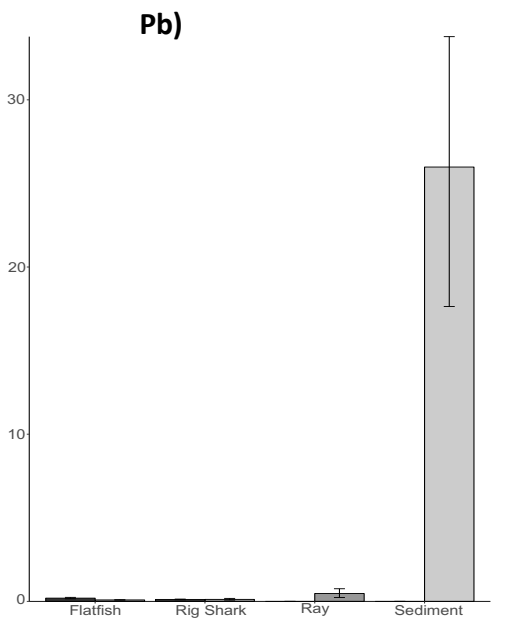

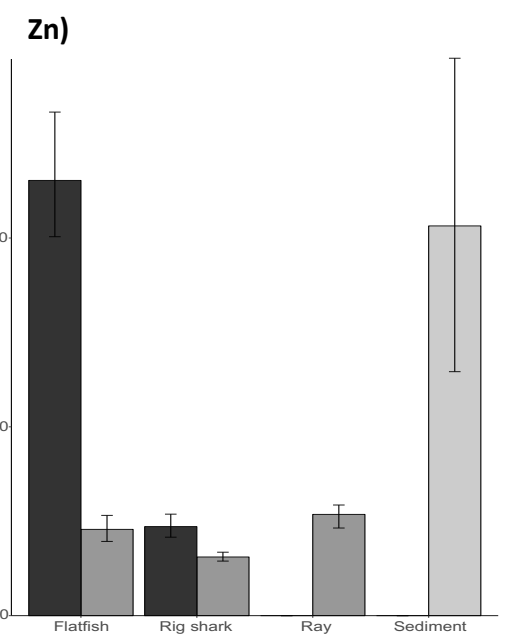

$\mathrm{Hg})$

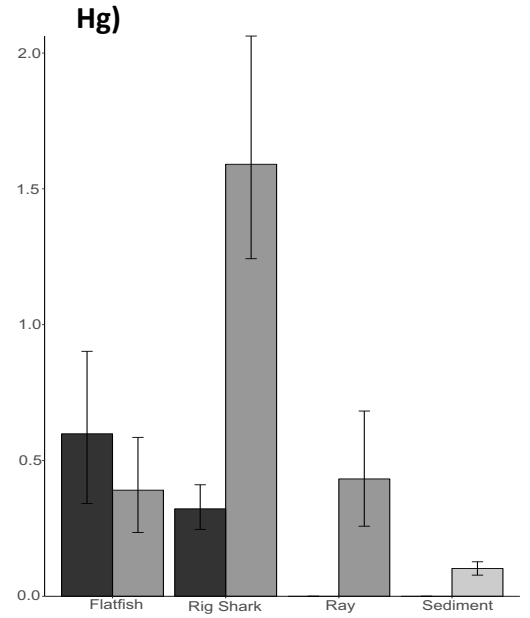

Species/Sediment

Figure 26: Barchart showing the relationship between heavy metals $(\mathrm{Cu}, \mathrm{Zn}, \mathrm{Pb}, \mathrm{Hg}$ ) found in sediment samples sourced from Oliver (2016), and the concentration found in tissue (muscle and liver) of flatfish, rig shark and rays (short-tailed stingray and eagle ray) collected from Porirua Harbour. Error bars represent standard errors. 
Table 12: Mean concentrations of heavy metals $(\mathrm{Cu}, \mathrm{Zn}, \mathrm{Pb}, \mathrm{Hg})(\mathrm{mg} / \mathrm{kg} \mathrm{w} . \mathrm{w}) \pm$ standard deviations in the tissue (muscle and liver) of rig shark, yellow belly flounder, sand flounder, speckled sole, eagle ray and short tailed stingray caught in Porirua Harbour in 2018.

\begin{tabular}{|c|c|c|c|c|c|c|}
\hline Species & $N$ & Tissue & $\mathrm{Cu}$ & $Z n$ & $P b$ & $H g$ \\
\hline \multirow[t]{3}{*}{ Rig shark } & 21 & muscle & $0.17 \pm 0.090$ & $2.49 \pm$ & $0.01 \pm 0.0203$ & $0.23 \pm 0.1867$ \\
\hline & & & & 0.6215 & & \\
\hline & & liver & $0.97 \pm 0.343$ & $4.88 \pm 2.05$ & $0.03 \pm 0.017$ & $0.07 \pm 0.0492$ \\
\hline Yellow belly & 11 & muscle & $0.18 \pm 0.056$ & $2.96 \pm$ & $0.01 \pm 0.005$ & $0.06 \pm 0.052$ \\
\hline \multirow[t]{3}{*}{ flounder } & & & & 0.4011 & & \\
\hline & & liver & $1.5 \pm 0.826$ & $18.94 \pm$ & $0.03 \pm 0.0104$ & $0.12 \pm 0.1057$ \\
\hline & & & & 3.218 & & \\
\hline \multirow[t]{6}{*}{ Sand flounder } & $5^{*}$ & muscle & $0.35 \pm 0.493$ & $3.45 \pm 1.597$ & $0.01 \pm 0.0112$ & $0.02 \pm 0.0074$ \\
\hline & 2 sand flounder & & & & & \\
\hline & $<14 \mathrm{~cm}$ pooled into & & & & & \\
\hline & one sample & & & & & \\
\hline & & liver & $1.093 \pm$ & $16.68 \pm 7.37$ & $0.03 \pm 0.0086$ & $0.02 \pm 0.018$ \\
\hline & & & 0.684 & & & \\
\hline \multirow[t]{5}{*}{ Speckled sole } & $10^{*}$ & muscle & $0.37 \pm N / A$ & $2.42 \pm N / A$ & $0.01 \pm N / A$ & $0.007 \pm N / A$ \\
\hline & *pooled into $n=1$ & & & & & \\
\hline & muscle, $n=1$ liver & & & & & \\
\hline & sample & & & & & \\
\hline & & liver & $1.93 \pm N / A$ & $56.18 \pm N / A$ & $0.42 \pm N / A$ & $0.02 \pm N / A$ \\
\hline Eagle ray & 4 & muscle & $0.13 \pm 0.07$ & $7.89 \pm 0.32$ & $0.07 \pm 0.06$ & $0.09 \pm 0.03$ \\
\hline $\begin{array}{l}\text { Short-tailed } \\
\text { stingray }\end{array}$ & 1 & muscle & $0.67 \pm N / A$ & $4.01 \pm N / A$ & $0.2 \pm N / A$ & $0.19 \pm N / A$ \\
\hline
\end{tabular}


Heavy metal concentration in rig shark embryos

Elemental levels for female rig shark and their embryos were expressed as $\mathrm{mg} / \mathrm{kg}$ of dry weight $(d . w)$. Heavy metal burden per embryo was not influenced by the total litter size for $\mathrm{Cu}, \mathrm{Zn}, \mathrm{Pb}$ and $\mathrm{Hg}(\mathrm{p}=>0.05)$ (Appendix F).

\section{Copper (Cu)}

There was no linear relationship between embryo $\mathrm{Cu}$ and levels found in mothers tissues (Figure 27a,b; Table 14). No relationship was found between TL (and weight) of the mother or the embryo and their associated Cu levels (Figure 28; Table 14). However, mean Cu level in embryos $(4.08 \mathrm{mg} / \mathrm{kg} \mathrm{d}$.w) was 4-times higher than the mother's muscle concentration of $0.95 \mathrm{mg} / \mathrm{kg}$ d.w (one-way ANOVA: $\mathrm{F}_{1,11}=69.56, \mathrm{p}=<0.05$ ), but there was no significant difference between embryo and mother's liver Cu concentration of $3.81 \mathrm{mg} / \mathrm{kg} \mathrm{d} . w$ (Figure 29a; Table 13).

a)

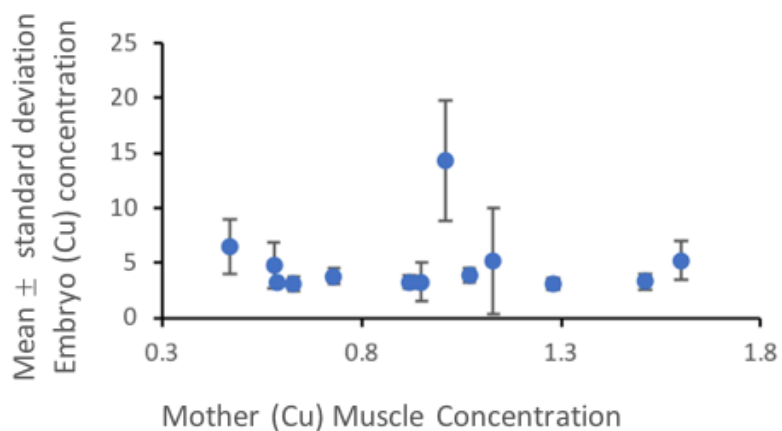

b)

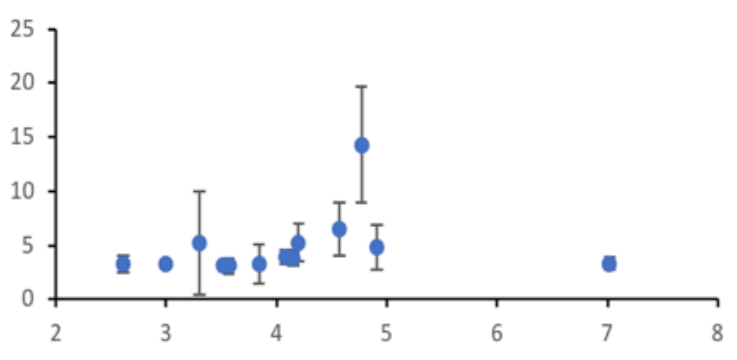

Mother (Cu) Liver Concentration

Figure 27: Relationship between copper ( $\mathrm{Cu}$ ) concentration mean \pm standard deviation in rig shark embryos and a) mother $\mathrm{Cu}$ muscle concentration, b) mother Cu liver concentration $(\mathrm{mg} / \mathrm{kg} d . w)$ in rig shark caught in Porirua Harbour in 2018. 
a)

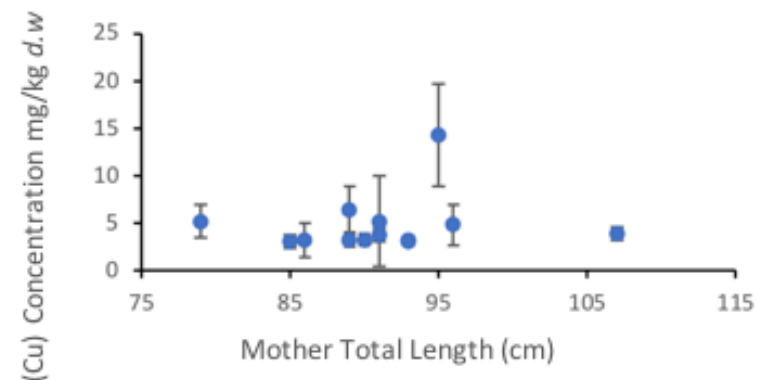

c)

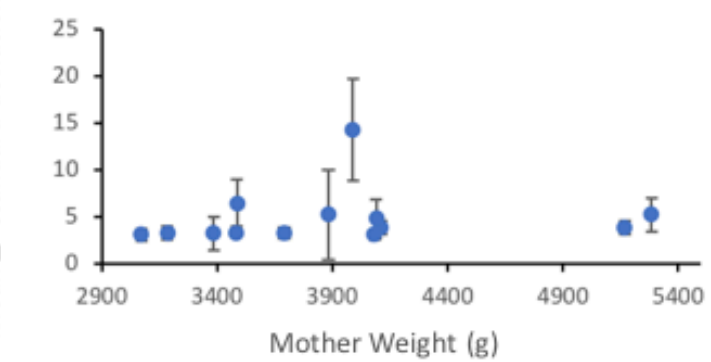

b)

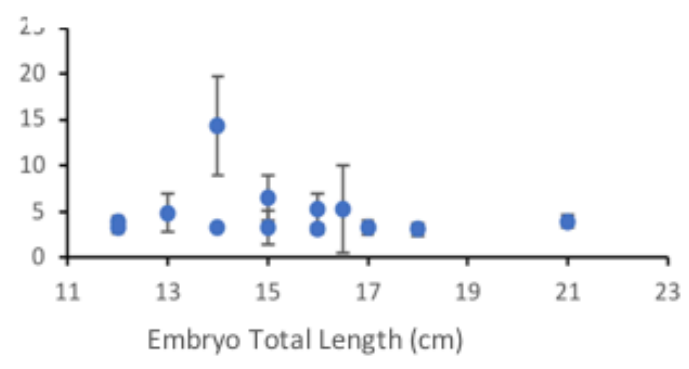

d)

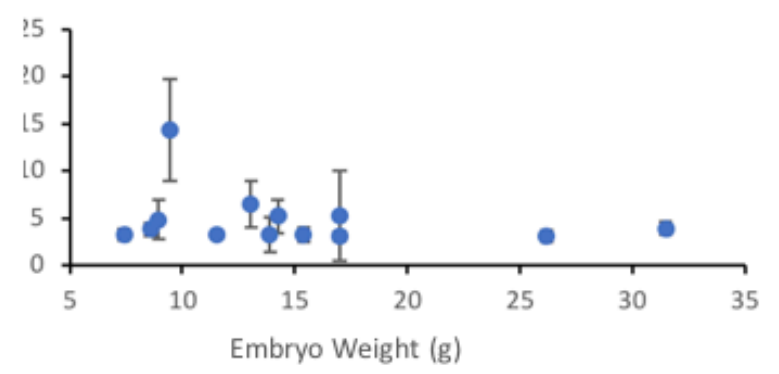

Figure 28: Relationship between copper (Cu) concentration mean \pm standard deviation in rig shark embryos and a) mother Total Length $(\mathrm{cm})$, b) embryo Total Length $(\mathrm{cm}), \mathrm{c})$ mother weight $(\mathrm{g})$, d) embryo weight $(\mathrm{g})$ in rig shark caught in Porirua Harbour.

a)

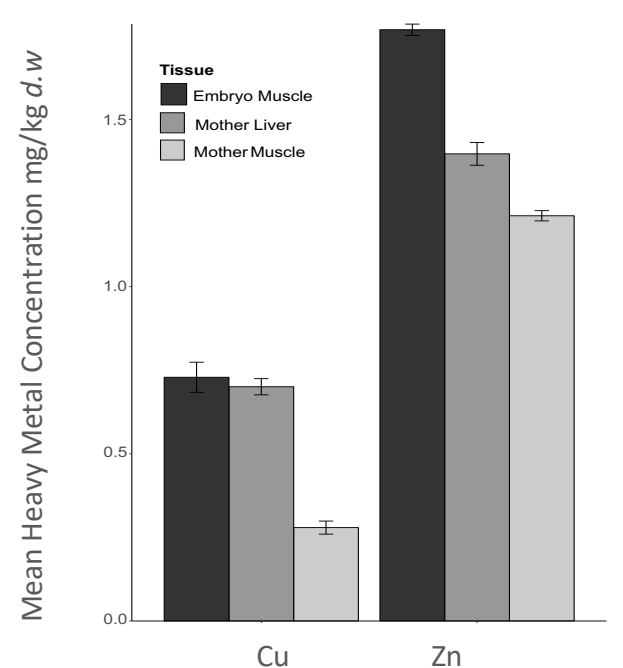

b)

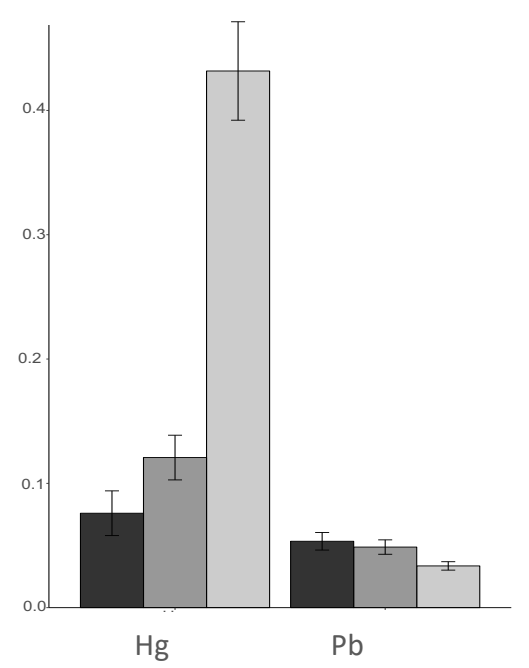

Essential/Non-Essential Metals

Figure 27: Bar chart showing a) concentration of essential metals ( $\mathrm{Cu}$ and $\mathrm{Zn}$ ) in mother and embryo tissues, $\mathrm{b}$ ) concentrations of non-essential metals $(\mathrm{Pb}$ and $\mathrm{Hg})$ in mother and embryo tissues of rig shark caught in Porirua Harbour. Error bars represent standard errors. 
Table 13: Mean heavy metal concentrations $(\mathrm{Cu}, \mathrm{Zn}, \mathrm{Pb}, \mathrm{Hg})(\mathrm{mg} / \mathrm{kg} \mathrm{d} . \mathrm{w}) \pm$ standard deviations, and the range found in the tissue (muscle and liver) of adult rig shark and the tissue (muscle) of their near-term embryos.

\begin{tabular}{llll}
\hline & $\begin{array}{l}\text { Mother Liver } \\
\text { Concentration }\end{array}$ & $\begin{array}{l}\text { Mother } \\
\text { Muscle } \\
\text { Concentration }\end{array}$ & $\begin{array}{l}\text { Embryo } \\
\text { Muscle } \\
\text { Concentration }\end{array}$ \\
\hline $\begin{array}{l}\text { Copper } \\
\text { (Cu) }\end{array}$ & $3.81 \pm 3.03$ & $0.95 \pm 0.359$ & $4.08 \pm 1.104$ \\
\hline Range & $2.61-7.02$ & $0.47-1.6$ & $2.46-43.2$ \\
\hline Zinc (Zn) & $23.4 \pm 8.012$ & $14.8 \pm 2.097$ & $58.4 \pm 8.214$ \\
\hline Range & $15.5-45.8$ & $12.3-19.3$ & $36-103$ \\
\hline $\begin{array}{l}\text { Lead } \\
\text { (Pb) }\end{array}$ & $0.11 \pm 0.055$ & $0.08 \pm 0.028$ & $0.125 \pm 0.068$ \\
\hline Range & $0.07-0.26$ & $0.001-0.12$ & $0.05-0.43$ \\
\hline Mercury & $0.33 \pm 0.215$ & $1.45 \pm 1.155$ & $0.127 \pm$ \\
(Hg) & & & 0.212852 \\
\hline Range & $0.09-0.84$ & $0.71-5.18$ & $0.038-1.15$ \\
\hline
\end{tabular}

\section{$\operatorname{Zinc}(Z n)$}

There was a significant difference between embryo $\mathrm{Zn}$ and levels found in mothers tissues (one-way ANOVA: $F_{2,186}=69.56, p<0.001$ ) (Figure 29a; Table 13), but no significant linear relationship (Figure 30; Table 14). Mean embryo levels of $58.5 \mathrm{mg} / \mathrm{kg} d . w$ were 3-times higher than the mothers tissue level of $14.8 \mathrm{mg} / \mathrm{kg} \mathrm{d.w} \mathrm{(Figure} \mathrm{29a;} \mathrm{Table} \mathrm{13).} \mathrm{A} \mathrm{strong} \mathrm{linear}$ relationship was found between mothers TL and Zn levels in rig shark embryos, with smaller females having litters with higher Zn (Figure 31a), but there was a weaker relationship with embryo TL, and embryo weight (Figure 31b, d; Table 14). 
a)

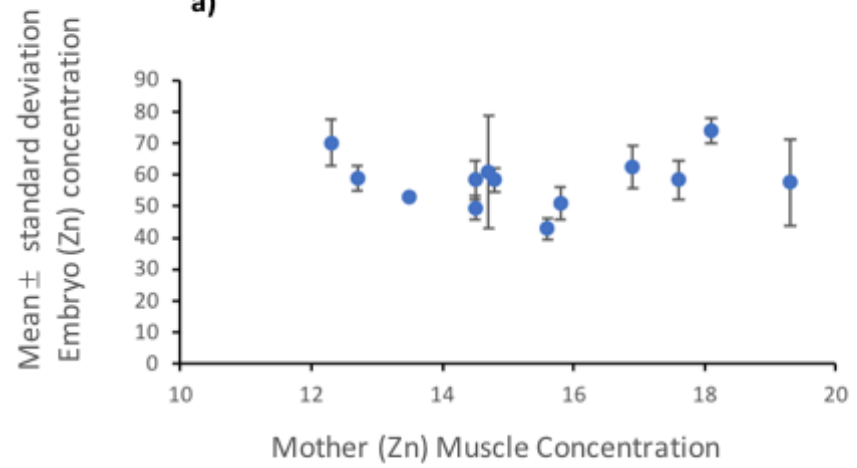

b)

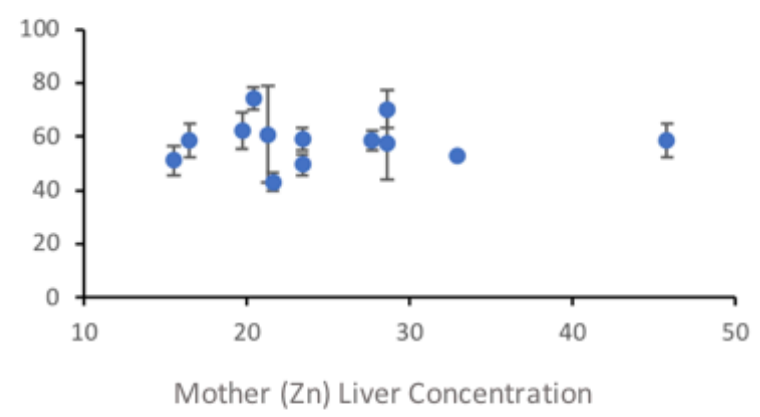

Figure 30: Relationship between Zinc ( $\mathrm{Zn}$ ) concentration mean \pm standard deviation in rig shark embryos and a) mother Zn muscle concentration, b) mother Zn liver concentration ( $\mathrm{mg} / \mathrm{kg}$ d.w) in rig shark caught in Porirua Harbour in 2018.

a)

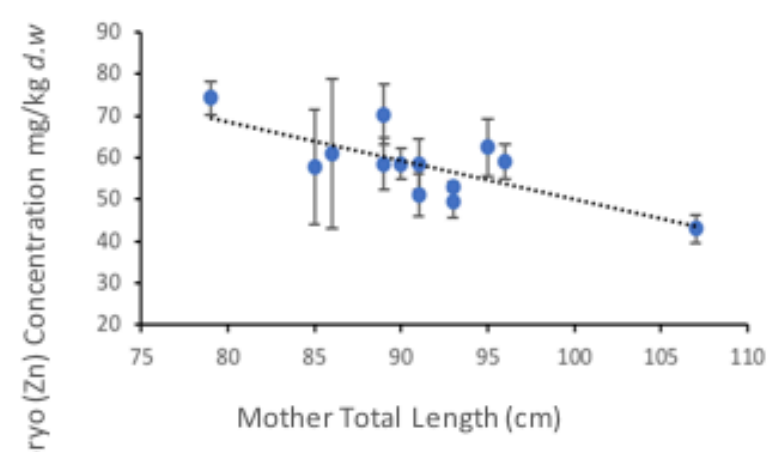

c)

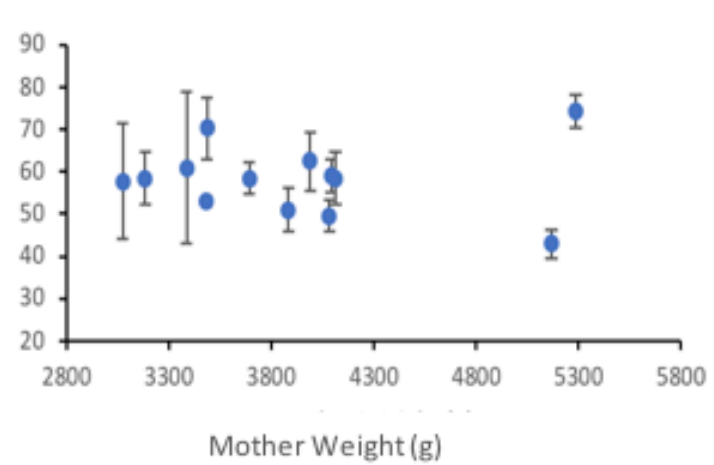

b)

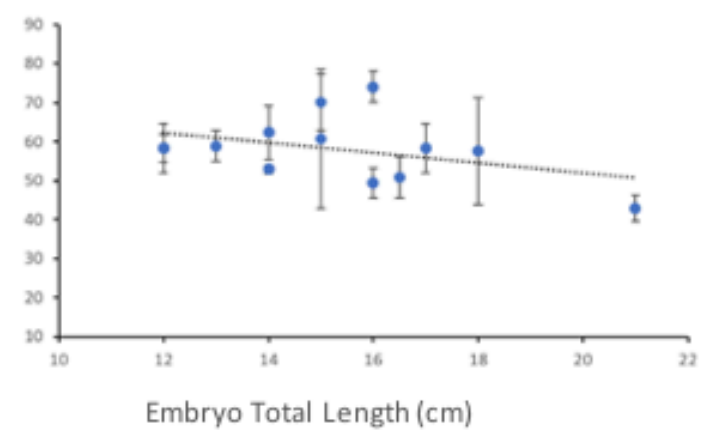

d)

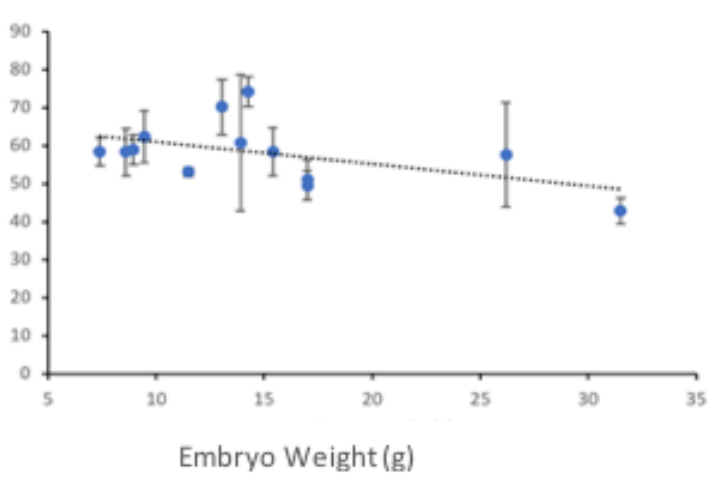

Figure 31: Relationship between Zinc (Zn) concentration mean \pm standard deviation in rig shark embryos and a) mother total Length $(\mathrm{cm})$, b) embryo total length $(\mathrm{cm}), c)$ mother weight $(\mathrm{g})$, d) embryo weight $(\mathrm{g})$ in rig shark caught in Porirua Harbour. 
Table 14: Linear model results showing relationship between embryo (muscle) heavy metal concentration ( $\mathrm{Cu}, \mathrm{Zn}, \mathrm{Pb}, \mathrm{Hg}$ ) and mother tissue (liver and muscle) concentrations, embryo and mother weight ( $\mathrm{g}$ ), embryo and mother Total Length (cm). Results shown in $\mathrm{mg} / \mathrm{kg} \mathrm{d.w}$. Statistically significant results $\mathrm{p}=<0.05$ indicated by*

\begin{tabular}{|c|c|c|c|}
\hline Embryo Heavy Metal & Dependent & $r^{2}$ & P-value \\
\hline Concentration & Variable & & \\
\hline \multirow[t]{6}{*}{ Embryo $\mathrm{Cu}$} & Mother muscle $\mathrm{Cu}$ & 0.01564 & 0.684 \\
\hline & Mother liver $\mathrm{Cu}$ & 0.03037 & 0.5691 \\
\hline & Mother TL & 0.03266 & 0.5546 \\
\hline & Embryo TL & 0.004287 & 0.593 \\
\hline & Mother Weight & $<0.001$ & 0.9906 \\
\hline & Embryo Weight & 0.008503 & 0.4511 \\
\hline \multirow[t]{6}{*}{ Embryo Zn } & Mother muscle Zn & 0.01505 & 0.6897 \\
\hline & Mother liver Zn & 0.01921 & 0.6516 \\
\hline & Mother TL & 0.7458 & $0.0001421 *$ \\
\hline & Embryo TL & 0.08066 & $0.01803^{*}$ \\
\hline & Mother Weight & 0.03043 & 0.5687 \\
\hline & Embryo Weight & 0.1117 & $0.005016^{*}$ \\
\hline \multirow[t]{6}{*}{ Embryo Pb } & Mother muscle $\mathrm{Pb}$ & 0.01611 & 0.6794 \\
\hline & Mother liver $\mathrm{Pb}$ & 0.001201 & 0.9105 \\
\hline & Mother TL & 0.02716 & 0.5906 \\
\hline & Embryo TL & 0.06528 & $0.0341^{*}$ \\
\hline & Mother Weight & 0.003355 & 0.8509 \\
\hline & Embryo Weight & 0.07 & $0.02352^{*}$ \\
\hline \multirow[t]{6}{*}{ Embryo Hg } & Mother muscle Hg & 0.52 & $<0.001$ \\
\hline & Mother liver $\mathrm{Hg}$ & 0.84 & $<0.001$ \\
\hline & Mother TL & 0.07594 & 0.3621 \\
\hline & Embryo TL & 0.07054 & $0.02741^{*}$ \\
\hline & Mother Weight & 0.0003553 & 0.9513 \\
\hline & Embryo Weight & 0.16 & $0.03538^{*}$ \\
\hline
\end{tabular}

Lead $(\mathrm{Pb})$

There was no significant difference between embryo Pb levels and those found in mother's muscle (one-way ANOVA: $F_{1,11}=0.18, p=0.679$ ) and liver tissue (one-way ANOVA: $F_{1,11}=0.0$, $\mathrm{p}=0.91$ ) (Figure 29b), and no significant linear relationship (Figure 32; Table 14). Mean Pb levels ranged from $0.08-0.11$ across mother and embryo tissue (Table 13). A weak negative relationship was found between embryo weight, embryo $\mathrm{TL}$ and $\mathrm{Pb}$ levels in rig shark 
embryos, with smaller embryos having higher Pb levels, but there was no relationship with mother size (Figure 33; Table 14).

a)

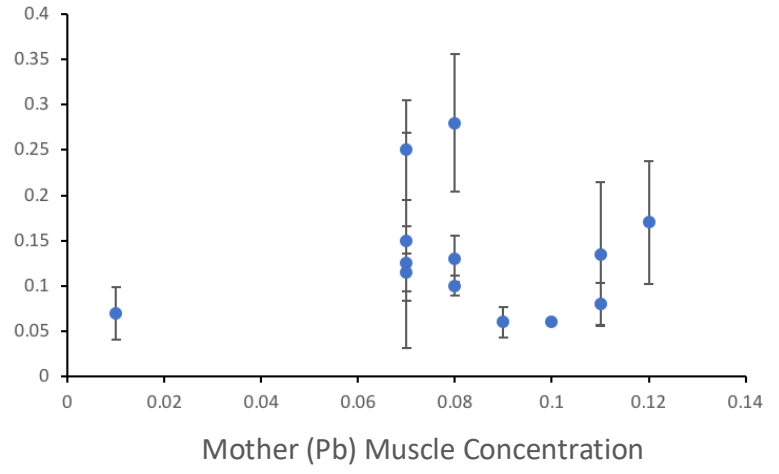

b)

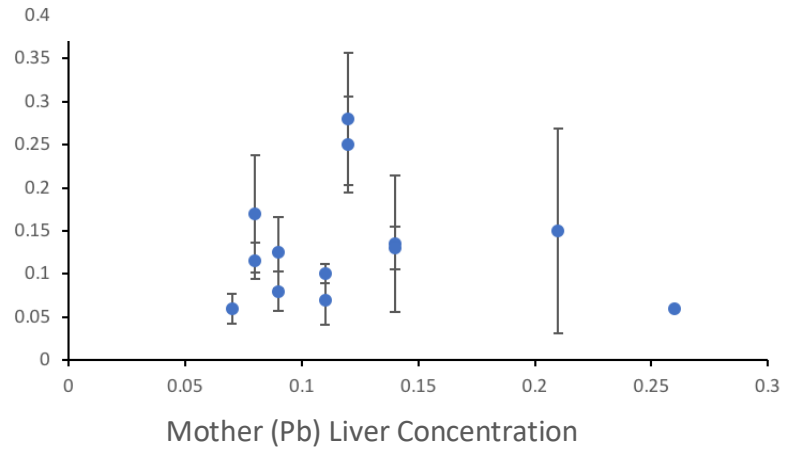

Figure 28: Relationship between Lead $(\mathrm{Pb})$ concentration mean \pm standard deviation in rig shark embryos and a) mother $\mathrm{Pb}$ muscle concentration, $\mathrm{b}$ ) mother $\mathrm{Pb}$ liver concentration $(\mathrm{mg} / \mathrm{kg} \mathrm{d.w)}$ in rig shark caught in Porirua Harbour in 2018.

a)

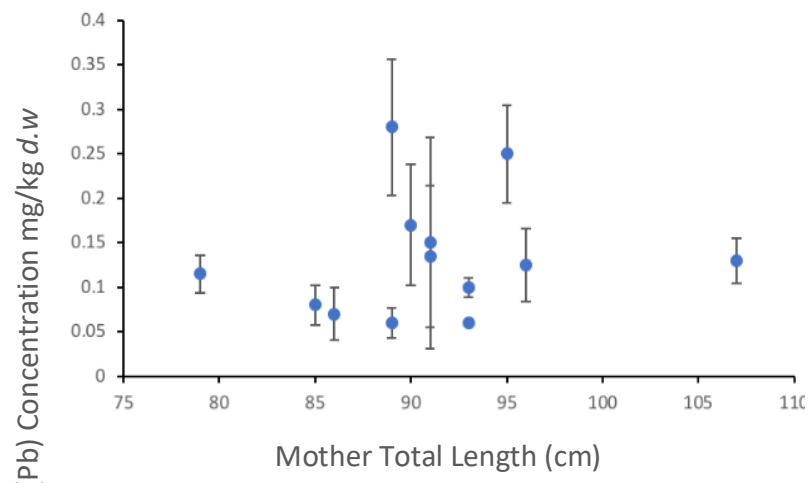

c)

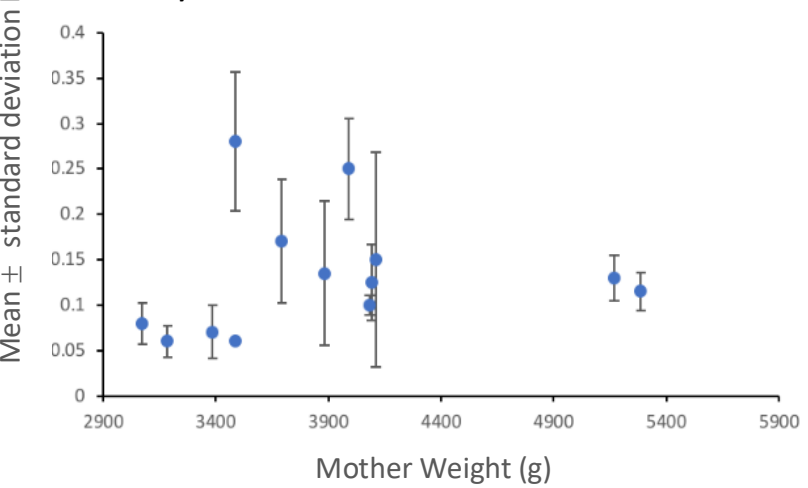

b)

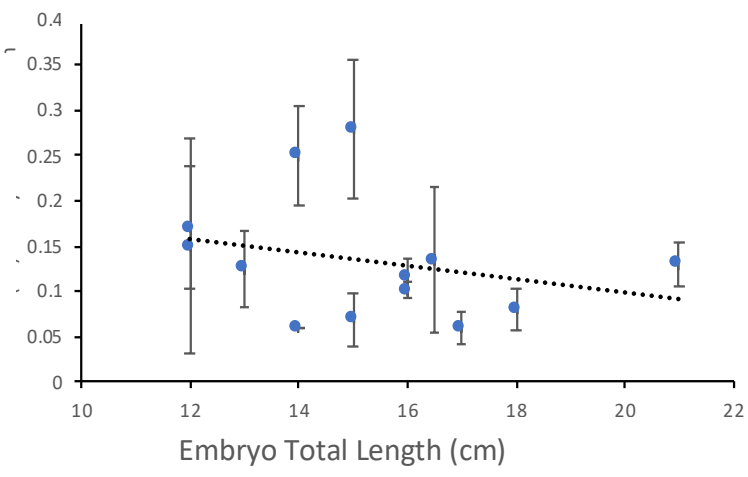

d)

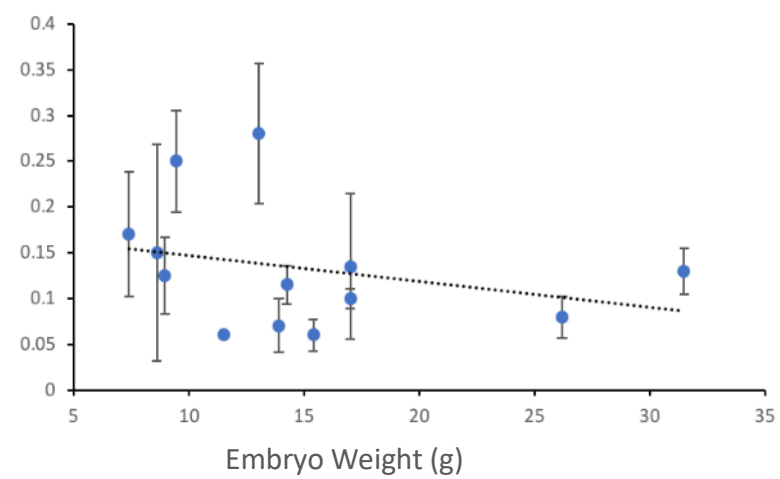

Figure 29: Relationship between Lead $(\mathrm{Pb})$ concentration mean \pm standard deviation in rig shark embryos and a) mother total Length $(\mathrm{cm}), \mathrm{b})$ embryo total length $(\mathrm{cm}), \mathrm{c})$ mother weight $(\mathrm{g})$, d) embryo weight $(\mathrm{g})$ in rig shark caught in Porirua Harbour. 


\section{$\operatorname{Mercury}(\mathrm{Hg})$}

A linear relationship was found between embryo $\mathrm{Hg}$ concentrations and mother muscle and liver tissue (Figure 34a, b; Table 14). There was a weak linear relationship with embryo Hg concentration and mothers TL, with larger mothers having embryos with higher levels of $\mathrm{Hg}$ (Figure 35a; Table 14). Smaller embryos had higher Hg levels (Figure 29b; Table 14). Hg was found in higher concentrations in mother's muscle and liver tissues than in embryos (Figure 29b; Table 13). Mother mean muscle Hg concentration was nearly 12 times higher than embryos, whereas the mother's liver concentrations only $30 \%$ higher (Figure 29b). Mother muscle tissue had the highest level of $\mathrm{Hg}$ recorded $(1.45 \mathrm{mg} / \mathrm{kg} \mathrm{d.w})$, which was 12-times higher than mean embryo $\mathrm{Hg}$ at $0.12 \mathrm{mg} / \mathrm{kg}$ d.w (Figure 29b; Table 13).
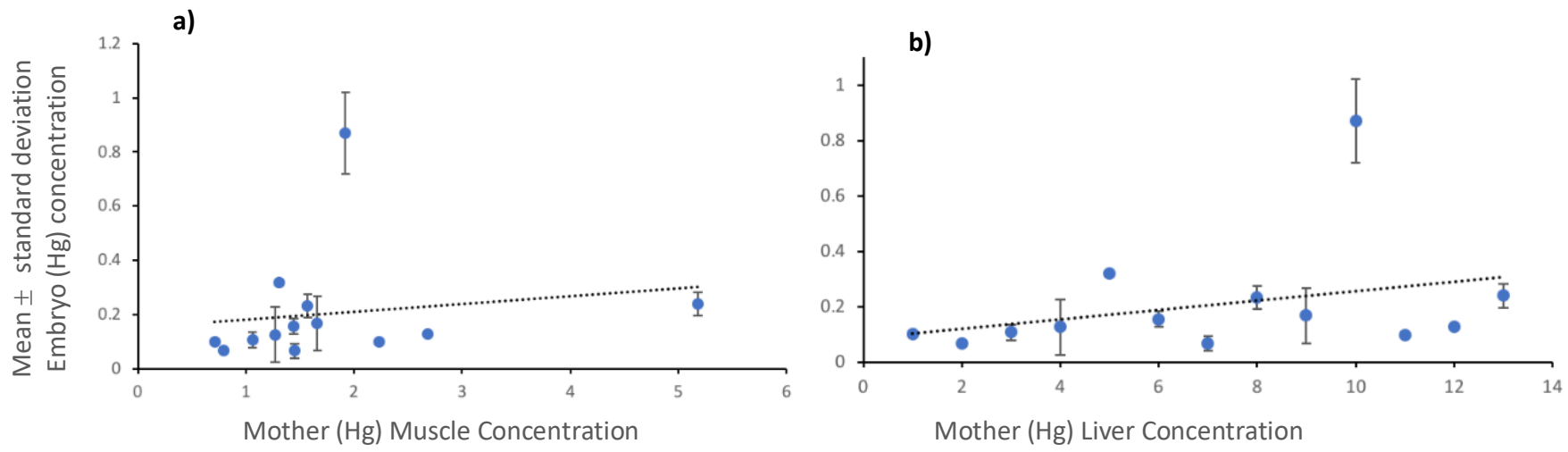

Figure 30: Relationship between Mercury ( $\mathrm{Hg}$ ) concentration mean \pm standard deviation in rig shark embryo and a) mother $\mathrm{Hg}$ muscle concentration, b) mother $\mathrm{Hg}$ liver concentration $(\mathrm{mg} / \mathrm{kg} \mathrm{d.w}$ ) in rig shark caught in Porirua Harbour in 2018.

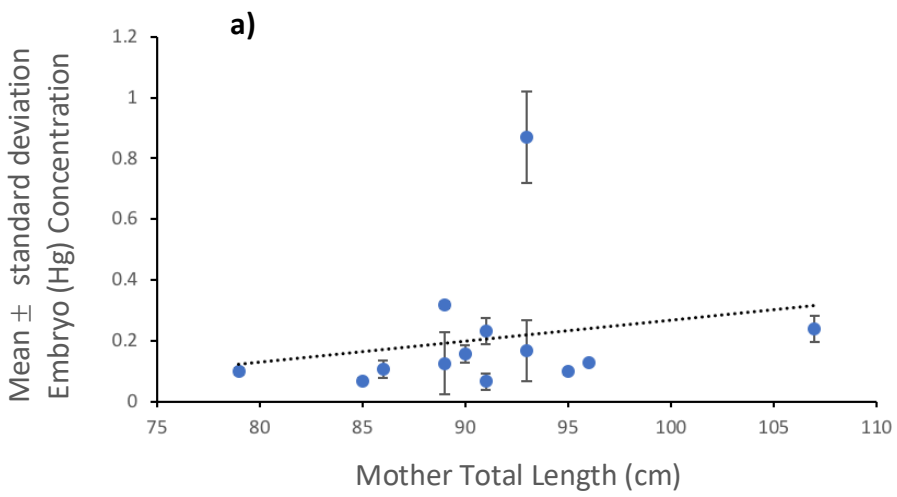

b)

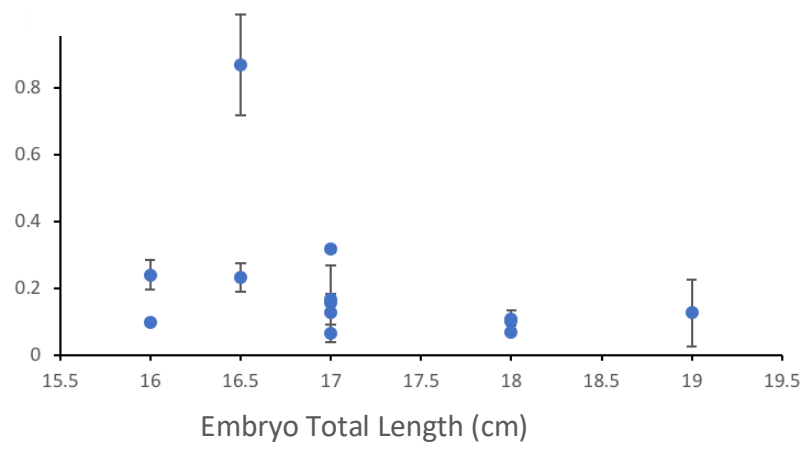

Figure 31: Relationship between Mercury ( $\mathrm{Hg}$ ) concentration mean \pm standard deviation $\mathrm{mg} / \mathrm{kg} d . w$ in embryo and a) mother Total Length, b) Embryo Total Length in rig shark caught in Porirua Harbour in 2018. 
a)

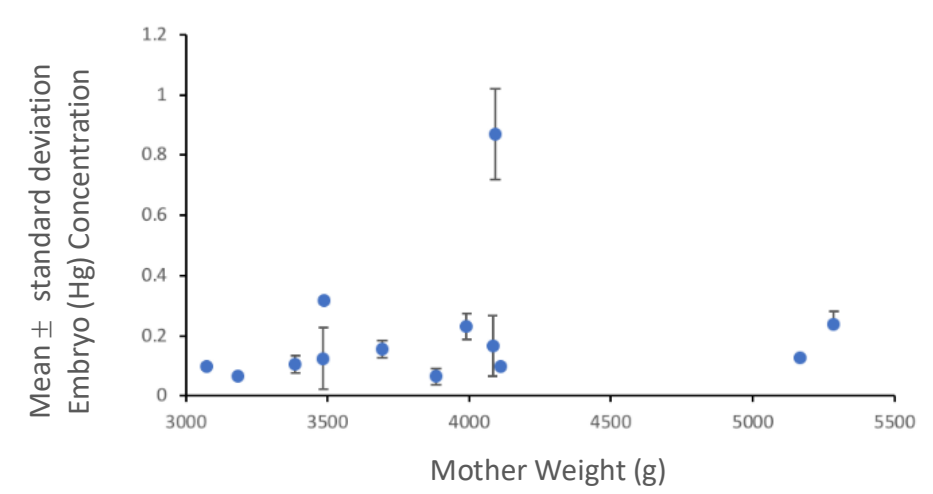

b)

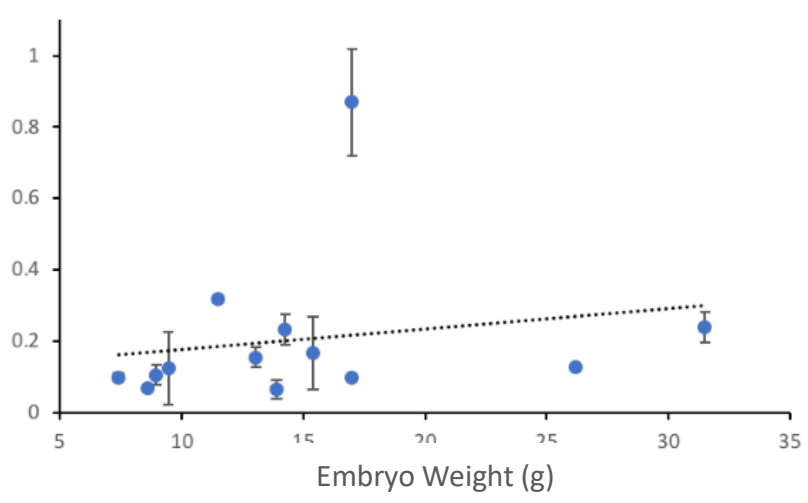

Figure 32: Relationship between Mercury $(\mathrm{Hg})$ concentration mean \pm standard deviation in embryo and a) mother weight ( $\mathrm{g}$ ) and, b) embryo weight $(\mathrm{g})$ in rig shark caught in Porirua Harbour.

\section{Metal interactions in rig shark embryos}

There was a negative relationship with embryo $\mathrm{Zn}$ concentrations and mother $\mathrm{Hg}$ liver concentrations $(r=0.55, m=69, p=0.0036)$ (Figure 37). There were no other relationships between metals within embryos or between embryos and mothers.

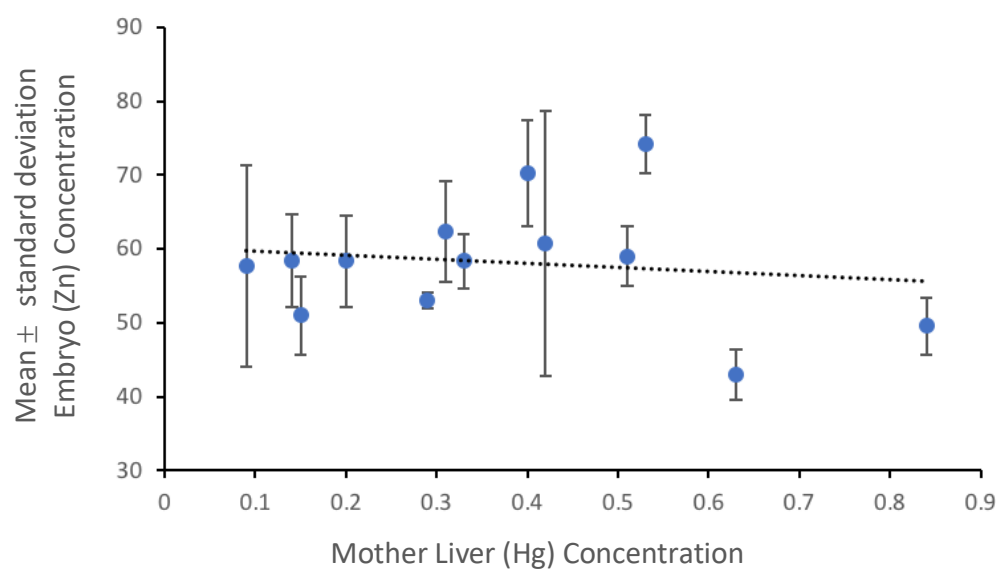

Figure 33: Relationship between Embryo Zinc (Zn) concentration and mother liver Hg concentrations mean \pm standard deviation. 


\section{Discussion}

This study provides the first comprehensive data on heavy metal accumulation in flatfish and elasmobranch species in Porirua Harbour. A number of studies have shown that various factors such as metal type, species, fish size, tissue type, trophic status and physiological state of fish can play a role in the tissue accumulation of heavy metals (Pourang et al. 2005; Rejomon et al. 2010), and this present study supports such findings. The levels of $\mathrm{Cu}, \mathrm{Zn}, \mathrm{Pb}$, and $\mathrm{Hg}$ were determined in the muscle tissue due to the importance of human consumption, whereas the liver was analysed because it is the target organ for heavy metal accumulation (Yilmaz 2003; Dural et al. 2007).

\section{Copper (Cu)}

$\mathrm{Cu}$ in muscle tissue in this present study are an order of magnitude less than those obtained in muscle tissue by Carvalho et al. (2005) $(1.3 \mathrm{mg} / \mathrm{kg})$, and were 2-times lower than the Indian Mackerel (Rastrelliger kanagurta), and the Malabar sole (Cynoglossus macrostomus) from the southeast coast of India (Rejomon et al. 2010). However, results were comparable with concentrations found in swordfish (Xiphias gladius) in Mozambique (Kojadinovic et al. 2007). Bosch et al. (2013) established that pregnant smooth-hound females had higher $\mathrm{Cu}$ concentrations than non-pregnant females in South Africa (Bosch et al. 2013), but this was not evident in this present study, perhaps due to smaller sample size. The concentration of $\mathrm{Cu}$ in muscle tissue of flatfish and rig shark from Porirua Harbour were far below the FAO (2003) regulatory value, establishing regular consumption of fish with such low amounts of $\mathrm{Cu}$ are not detrimental to human health.

Cu concentrations in liver tissue were higher in flatfish than those observed in rig shark. These results generally support those found in literature, with $\mathrm{Cu}$ concentrations within the same order of magnitude observed in Narrow tongue sole (Cynoglossus gracilis) (Zhao et al. 2010) 


\section{Zinc (Zn)}

Flatfish and rig shark didn't differ in muscle $\mathrm{Zn}$ concentration, but $\mathrm{Zn}$ in ray muscle tissue was elevated. Zn concentrations in flatfish in this present study were $50 \%$ higher than those found in demersal and pelagic fishes in India (Rejomon et al. 2010), but were in the same order of magnitude observed in Mumbai, which was attributed to the area having extensive upwelling of Zn-enriched waters (Krishnamurti \& Nair 1999; Rejomon 2005). Zn concentrations in muscle tissue of flatfish, rig shark and rays fell below FAO maximum guidelines of $30 \mathrm{mg} / \mathrm{kg}$ considered safe for human consumption (FAO 2003; Mendil et al. 2010).

Zn concentrations in liver tissue were higher in flatfish than those observed in rig shark. The highest concentration of $\mathrm{Zn}$ was recorded in speckled sole $56.18 \mathrm{mg} / \mathrm{kg}$, but was attributed to biomagnification within the samples as tissue from 10 individuals were pooled into one to reach the minimum limits for ICPMS. Zn concentrations in this study are in agreement with the freshwater ecosystems (Duran et al. 2015), and of Carvalho et al. (2005) who found a mean value of $19 \mathrm{mg} / \mathrm{kg}$, and the older work of Nebawi et al. (1987), who found fish in Alexandria, Egypt had Zn concentrations ranging from 16.5-40.5 mg/kg. Carvalho et al. (2005) found higher $\mathrm{Zn}$ concentrations in liver tissue of benthic fish with a preference for sandy/muddy habitats, whereas pelagic fishes had lower Zn. Multiple works have found $\mathrm{Zn}$ to be in higher concentrations than any other metal evaluated (Wong et al. 2001; Carvalho et al. 2005).

\section{Lead $(\mathrm{Pb})$}

$\mathrm{Pb}$ in muscle was in the same order of magnitude with swordfish (X. gladius) and skipjack tuna (Katsuwonus pelamis) in Mozambique (Kojadinovic et al. 2007), barramundi (Lates calcarifer) in Mumbai (Krishnamurti, \& Nair 1999), and mangrove snapper (Lutjanus griseus) and the star snapper (Lutjanus Stellatus) in China (Leung et al. 2014). Muscle Pb concentration in this present study was also in the same range of orange-spotted grouper (Epinephelus coioides), spiny turbot (Psettodes erumei) and elongate sole (Solea elongate), all of which fell below international guidelines for human consumption in the Persian Gulf (Pourang et al. 2005). Concentrations of $\mathrm{Pb}$ found in Turkey ranged 5-10 times more than levels seen in this present study (Mendil et al. 2010), but were in similar concentrations found in rays in Porirua Harbour. 
However, $\mathrm{Pb}$ concentrations in muscle tissue in this current study were 3-times lower than levels found in malabar sole (C. macrostomus) in India (Rejomon et al. 2010). Although stingrays had the highest $\mathrm{Pb}$ concentration in this present study, all levels fell well below FAO (2003) Maximum Allowable Limit (MAL) of $0.2 \mathrm{mg} / \mathrm{kg}$ for edible fish tissue.

Low $\mathrm{Pb}$ concentrations in the fish liver have been observed in milkfish (Chanos chanos) and were attributed to a lack of $\mathrm{Pb}$ binding proteins related to metallothioneins (Daka et al. 2006; Narges et al. 2012). Moreover, there is no specific protein in liver cytosol with high affinity for $\mathrm{Pb}$ (Narges et al. 2012). Accumulated $\mathrm{Pb}$ being distributed to other tissues rather than the liver has been observed in European bass (Dicentrarchus labrax) (Odzak \& Zvonaric 1995), hake (Merluccius merluccius) and red mullet (Mullus barbatus) (Gaspic et al. 2002).

\section{Mercury (Hg)}

Of the two non-essential elements examined, $\mathrm{Hg}$ was the most abundant in all species sampled in Porirua Harbour. $\mathrm{Hg}$ is one of the most toxic elements to the environment and humans, which explains why it is the most studied (Carvalho, Pereira \& Brito 2002; Carvalho et al. 2005). Hg in fish tissues is known to follow the liver > muscle order in terms of accumulation (Storelli et al. 2005; Kojadinovic et al. 2007). However, accelerated Hg levels in the muscle tissue, as noted in rig shark, has been observed in predatory fish such as Common dolphinfish (Coryphaenidae spp.), Atlantic bluefin tuna (Thunnus thynnus) and swordfish (X. gladius) (Bustamante et al. 2003; Kojadinovic et al. 2007). Such patterns are reflective of accumulation over long time frames, especially in older fish (Kojadinovic et al. 2007). However, $\mathrm{Hg}$ concentration in rig shark muscle tissue was 3-4 times lower than levels found in smooth-hounds in South Africa (Bosch et al. 2013; Bosch et al. 2016). Similarly, Bradley et al. (2017) established that muscle tissue represents the largest concentration of $\mathrm{Hg}$ present in fish, and high concentrations of muscle $\mathrm{Hg}$ has been observed in tusks (brosme brosme) (Berg et al. 2000). Flatfish fell well below the Maximum Allowable Limit of $0.5 \mathrm{mg} / \mathrm{kg}$, and rig shark fell below the FAO (2003) Maximum Allowable Limit of $1 \mathrm{mg} / \mathrm{kg}$. However, two pregnant female rig shark had elevated levels of $\mathrm{Hg}$ at 0.83 and $0.73 \mathrm{mg} / \mathrm{kg}$, which fall just below the regulatory guidelines. 
In contrast, the concentration of $\mathrm{Hg}$ in liver tissue were slightly higher in flatfish. The distribution of $\mathrm{Hg}$ into tissues is dependent on the level of the contaminant in the environment, and has been observed in freshwater (Havelkova et al. 2008), and marine environments (Abreu et al. 2000). In Hg polluted areas, Hg concentration is higher in the liver than muscle tissue, and has been observed in the European sea bass (D. labrax), where $\mathrm{Hg}$ concentrations in the liver were $50 \%$ higher than levels in the muscle from polluted localities (Abreu et al. 2000). Honda et al. (1983) found $\mathrm{Hg}$ concentrations in the liver to be $50 \%$ higher than levels found in muscle tissue in the bald rock cod (Pagothenia borchgreinki). It has also been established that $\mathrm{Hg}$ concentrations present in the liver are due to the liver being the organ where de-methylation of the organic to inorganic (methylmercury) takes place, and where it is stored and metabolized (Maršálek et al. 2005; Havelkova et al. 2008). However, there are no human health standards for the liver because the organs are rarely consumed or used in oil production, therefore concentrations exceeding regulatory thresholds are unlikely to be a health hazard (Kojadinovic et al. 2007).

It is generally accepted that $\mathrm{Hg}$ present in tissue is methylmercury ( $\mathrm{MeHg}$ ), which is the most toxic form of Hg (Kojadinovic et al. 2007; Carvalho et al. 2005; Bosch et al. 2016). Burger \& Gochfield (2004) established MeHg accounted for $75-100 \%$ of total $\mathrm{Hg}$ in fish tissue. Bloom (1992) confirmed that 95\% of $\mathrm{Hg}$ in fish muscle alone is MeHg (Branco et al. 2007). Current evidence has found that MeHg is bound to cytosine residues in proteins (Harris et al. 2003), and it was established that MeHg in dogfish (S. acanthias) muscle tissue was present as MeHgCys (Lemes \& Wang 2009). To date, MeHgCys is considered the most relevant form for human exposure to contaminated fish muscle (Bradley et al. 2017). However, speciation of $\mathrm{Hg}$ is not determined in many studies due to limited availability and the high cost of analytical equipment and methods (Bosch et al. 2016).

\section{Tissue distribution}

\section{Muscle}

Distribution of heavy metals in organisms is not uniform, and they accumulate in target organs such as the gonads, liver, kidney, brain, and gills simultaneously (Okoto et al. 2014). In general, metal accumulation in muscle tissue is low in comparison to other organs (Wong et 
al. 2001; Dural et al. 2007). My results show that metal accumulation is highest in the liver and relatively low in muscle. My findings are supported in the literature, especially with an interspecies difference in the accumulation of heavy metals in tissue types (Yilmaz 2003; Dural et al. 2007). Canli \& Atli (2003) determined a low level of binding proteins in fish muscle results in a lower concentration of heavy metals accumulating in this tissue. Muscle tissue has been established as a poor indicator for most heavy metals (Miller et al. 1992; Durak et al. 2007), except for $\mathrm{Hg}$ which shows a higher affinity for muscle tissue for some species (Miller et al. 1992; Jezierska \& Witeska 2001; Stankevičiūtè et al. 2017; Dural et al. 2007).

Concern has been raised over fish having two types of skeletal muscle that can accumulate metals (Mull et al. 2012). Aerobic red muscle contains high levels of myoglobin, lipids, and glycogen and is more pronounced in active predatory fish (Khoshnamvand 2013). White muscle depends on anaerobic metabolism for energy, perform vigorous activity for short periods and is pronounced in benthic fish (Khoshnamvand 2013). Research typically fails to specify the muscle type sampled which could contribute to the high degree of variability among different studies (Miziray \& Kiminer 2016). Recent literature has begun to consider these differences, with white muscle accumulating metals at a lower rate than red muscle in a range of commercial and game fish (Burger et al. 2013; Khoshnamvand. 2013; Miziray \& Kiminer 2016). White muscle tissue was used in this present study, so it is unlikely the differences between species was attributed to different muscle types.

\section{Liver}

The liver is a good indicator of heavy metal exposure due to its essential role in metabolism (Dural et al. 2007). The liver is also a good bioindicator as the metals present are generally proportional to those present in the surrounding environment (Dural et al. 2007; Benedetti et al. 2009). Every metal was highest in the liver tissue in this current study, except for $\mathrm{Hg}$ which was highest in the muscle tissue of rig shark, and results are comparable with multiple works (Canli \& Atli 2003; Elnabris et al. 2013; Pouli et al. 2017). 


\section{Alternative organs}

Multiple tissue types can be used as bioindicators for heavy metal pollution (Khaled 2004; AlWeher 2008). Al-Weher (2008) established gill tissue and hard tissues such as scales and bones accumulate the highest rate of $\mathrm{Cd}$, and agrees with the literature (Khaled 2004; AlWeher 2008). Khaled (2004) found Cd levels in gill tissue was higher than concentrations found in the liver. Al-Weher (2004) also found Cu showed a high affinity for gill tissue, whereas muscle had the lowest level. $\mathrm{Cu}$ is also known to accumulate in high concentrations in the alkaline environment in the intestines (Wong et al. 2001). Chan (1995) found Pb showed higher affinity for fish bones and gills than in muscle and liver tissue. Akoto et al. (2014) established the loss of accumulated Cd was immediate from muscle tissue, but stayed at high concentrations in liver and kidney tissue. In a Hong Kong study on cultured fish sites, Zn was found in highest levels in gonads (Wong et al. 2001). A New Zealand study supports these findings, finding gonads were the primary source of $\mathrm{Zn}$ in several species of marine fishes (Brooks and Rumsey 1974). Akoto et al. (2014) addressed the issue that metals in a single tissue does not necessarily represent the overall heavy metal burden of the organism. It is important to note that only two tissue types were examined in this present study, leaving distributions in many other tissue types, and possible implications of these, undetermined.

\section{Heavy metal interactions}

It has been long established that synergistic, additive and antagonist effects can occur in fishes (Jezierska \& Witeska 2001). Heavy metals can compete for binding sites, or the metals can influence one another (Bosch et al. 2016). Chu \& Chow (2002) established $\mathrm{Hg}, \mathrm{Pb}$ and $\mathrm{Cu}$ have a synergistic effect, and $\mathrm{Zn}$ tends to neutralize toxic effects and thus increase in concentration with each other. Duran et al. (2015) found Cu and Zn had antagonistic effects on rainbow trout (O. mykiss), with metal accumulation higher in mixture experiments than in single exposures. Similar interactions were seen in salmon (Sprague 1987). This is supported by this present research, where strong positive relationships were found between $\mathrm{Cu}, \mathrm{Zn}$, and $\mathrm{Hg}$ in muscle and liver tissues in rig shark and flatfish.

$\mathrm{Zn}$ has a neutralizing effect on the uptake of $\mathrm{Cd}$ because of $\mathrm{Zn}$-induced synthesis of metallothionein detoxifying and neutralizing $\mathrm{Cd}$ by binding to the metal (Kargin \& Çoğun 
1999; Chu \& Chow 2002; Benedetti et al. 2009). The presence of $\mathrm{Zn}$ in environmental metrics can cause $\mathrm{Cd}$ accumulation to decrease, and has been observed in the freshwater fish Nile Tilapia (Tilapia niloticia) (Kargin \& Çoğun 1999), and invertebrates such as blue mussel (Mytilus edulis planulatus), freshwater clams (Anadonta cygnea) (Hemelraad et al. 1987), and gastropods (Daka et al. 2006). Zn significantly increased Cd elimination in the liver of Nile Tilapia (T. niloticia) (Kargin \& Çoğun 1999), and gills of the Zebrafish (Brachydenio rerio) (Wicklund et al. 1988).

A linear relationship was observed between $\mathrm{Cu}$ and $\mathrm{Pb}$ in muscle tissue of pelagic and demersal fishes in India (Rejomon et al. 2010), and the Persian Gulf (Pourang et al. 2005). Although there was no linear relationship between $\mathrm{Cu}$ and $\mathrm{Pb}$ in this study, there was a direct relationship between $\mathrm{Zn}$ and $\mathrm{Pb}$ in rig shark. $\mathrm{Zn}$ and $\mathrm{Cu}$ have similar homeostatic processes which regulate their concentrations present in the environment (Ribeyre et al. 1995), so relationships between $\mathrm{Cu}$ and $\mathrm{Zn}$ could be related.

The process involved in heavy metal interactions remains, for the most part, unknown. Chemical reactions of each metal differ in the aquatic environment. Exact relationships between heavy metals can only be determined during extensive laboratory studies where fish are dosed and monitored (Ribeyre et al. 1995). Stankevičiūtè et al. (2017) established $0.1 \mathrm{mg} / \mathrm{kg} \mathrm{Cu} / \mathrm{Cd}$ exposure for 14 days caused cellular nuclear abnormalities in Atlantic salmon (Salmo salar). It is well established that DNA damage induces a range of diseases such as cancer, and reduced reproductive potential (Ramsdorf et al. 2012). Therefore, population and community-level dynamics can be impacted by these adverse effects (Stankevičiūtè et al. 2017). Contamination of $\mathrm{Hg}$ has been observed modifying the intercellular balance of $\mathrm{Cu}$, and a linear relationship has been seen in Zebrafish (B. rerio) (Ribeyre et al. 1995). This was attributed to an increase in $\mathrm{Cu}$ bound to heat stable compounds (HSC) occurring with an increase in $\mathrm{Hg}$ entering tissues (Ribeyre et al. 1995).

\section{Metallothionein protein}

Binding metals to metallothioneins is the most common detoxification strategy in marine organisms and a good indicator of overall heavy metal burden (Kojadinovic et al. 2007). This 
is because biosynthesis is induced after exposure to heavy metals, so levels of metallothioneins are positively correlated with the presence of metal concentrations, and the presence of metallothioneins have been found in liver, kidney, gill, and muscle (Liu et al. 1996). Uysal et al. (2009) established that higher bioaccumulation ratios found in the liver could be due to heavy metals binding to the amino group and the oxygen carboxylate of the metallothionein protein (Usero et al. 2004; Urena et al. 2007; Uysal et al. 2009). Heavy metal concentrations were typically highest in the liver in this present study, therefore It is possible that hepatic metallothioneins could provide a sink for these metals, but this hypothesis should be substantiated with metallothionein protein analysis.

\section{Biological Characteristics}

Size

Relationships between heavy metal concentration and body parameters have been established in many fish species, including sharks (Bosch et al. 2016). Negative relationships between essential heavy metal concentrations in fish tissues and fish size, is generally supported across literature (Canli \& Atli 2003). There was a negative relationship between fish size and muscle $\mathrm{Cu}$ concentrations in this present study, with smaller fish having higher levels of $\mathrm{Cu}$ in their muscle tissues. Similar negative relationships have been observed in other studies (Erasmus 2007), including within the Mustelus genus (Erasmus 2007; Bosch et al. 2016), which may be due to size-dependent variability in metabolic activity in fishes. Metabolic activity is generally higher in younger individuals and the rate of accumulation is positively correlated with metabolic rate (Nussey et al. 2000; Canli \& Atli 2003; Kojadinovic et al. 2007). Canli \& Alti (2003) concluded that metabolic activity alone was the most significant factor in heavy metal accumulation in his work in the Mediterranean. This may explain the negative correlation observed with muscular $\mathrm{Cu}$ in flatfish and rig shark.

Essential elements are quickly eliminated from fish tissue which is another explanation for little to no relationships being found with fish size, especially for Zn (Ribeyre et al. 1995). Widianarko et al. (2000) and Canli \& Atli (2003) concluded body concentrations of Zn are regulated and maintained at specific concentrations through metabolic processes, and may not reflect the ambient levels of this metal in the environment. These findings support earlier 
work by Phillips (1980) that state $\mathrm{Zn}$ is strictly regulated in fish tissue through homeostasis. However, an increase in Hepatosomatic Index HSI and the decrease of essential metals has been observed in yellowfin tuna (Thunnus albacares) and skipjack tuna (K. pelamis) and was attributed to the increase in liver and fish weight during fish growth (Kojadinovic et al. 2007). However, this was not seen in this present study.

It is generally hypothesized that non-essential metals have constant accumulation over time which results in a positive correlation with fish size (Akoto et al. 2014). This is because nonessential metals do not have any biological function and are by consequence not regulated by metabolism (Kojadinovic et al. 2007), but such results were not seen with $\mathrm{Pb}$ in this present study. Wong et al. (2001) found no changes in Pb concentration across fish tissue, fish size, sea water, sediment, and molluscs collected from fish culture zones. This has further been supported by older works where $\mathrm{Pb}$ concentrations are most commonly found at the detection limits (Carvalho et al. 2005; Thompson 1990). Yi \& Zang (2012) found no significant relationship between $\mathrm{Pb}$ concentrations in fish tissue and fish size in the Gulf of Qatar, whereas Widianarko et al. (2000) found a correlation with $\mathrm{Pb}$ and fish size in a freshwater ecosystem.

$\mathrm{Hg}$ accumulation with fish weight is the most documented (Storelli et al. 2002; Campbell et al. 2010; Bosch et al. 2016). In this present study, the $\mathrm{Hg}$ content in muscle (flatfish) and liver (flatfish and rig shark) depend upon the fish size, and similar results have been demonstrated in marine fishes (Kureishy 1993; Sadiq 2002). Relationships between Hg and fish weight have been seen in the European sea bass (D. labrax) (Abreu et al. 2000), and freshwater fish such as the bream (Abramis brama) (Farkas et al. 2003). Rig shark weight accounted for $27 \%$ of total variation in $\mathrm{Hg}$ levels found in liver tissue, which was significantly lower than results found by Adams \& McMichael (1999), which found weight accounted for $78 \%$ of total $\mathrm{Hg}$ variation in bonnethead sharks (Sphyrna tiburo).

Both laboratory and manipulative field studies have established MeHg are eliminated from fish tissue very slowly (Trudel \& Rasmussen 1997; Bradley et al. 2017). Hg is characterized by a slow elimination rate which results in an increase of concentration with fish size (Bosch et al. 2016). In flatfish, the most reliable indicator for $\mathrm{Hg}$ concentration was weight which 
accounted for $67 \%$ for total variation in muscle tissue. No such relationships were found in rig shark muscle tissue in this present study, but there was a strong relationship with liver $\mathrm{Hg}$ concentration. Bosch et al. (2016) did not find correlations between $\mathrm{Hg}$ in muscle tissue of mustelus smooth-hound in South Africa and attributed his results to species-specific metabolic activities and local environmental conditions.

Age

Metabolic processes being higher in younger fish may explain the negative relationships found between fish size and muscle $\mathrm{Cu}$ concentrations (Canli \& Atli 2003). Similarly, Cu concentrations were highest in flatfish which have a shorter life-span than elasmobranchs. Constant accumulation of non-essential metals over time result in a positive correlation with fish age (Akoto et al. 2014).

Bosch et al. (2016) estimated smooth-hound in Africa can reach 25 years of age and mature at eight years old, and similar findings were established by Francis (1992). However, because elasmobranchs are notoriously hard to age, size is commonly used as a proxy for age (Storelli et al. 2002; Kojadinovic et al. 2007). MeHg bind to thiol protein groups, which are known to increase in presence with age and fish size, so both can be used as an indicator for total heavy metal burden (Bradley et al. 2017). In addition, a possible hypothesis for higher $\mathrm{Pb}$ concentration in rays is because of their extended life history traits in comparison to rig shark and flatfish (Le Port \& Montgomery 2008; Le Port 2009; Last et al. 2016) (Appendix G). However, under this hypothesis, you would expect Hg to follow a similar pattern, when it was 2-times lower than rig shark muscle tissue. Therefore, careful consideration should be taken in comparing the results.

Sex

Multiple studies have found variation between sexes, with females typically having higher levels of $\mathrm{Zn}$ and $\mathrm{Cu}$ than males due to differences in metabolic demands (Canli \& Atli 2003). The accumulation of heavy metals, particularly essential metals during reproduction have been observed as increased activity of the metabolism (Kojadinovic et al. 2007). Bosch et al. (2013) established male smooth-hound had higher Hg concentrations than females which 
were attributed to males having a lower growth rate (Bosch et al. 2013). This may not be an eligible theory for New Zealand rig shark as Francis \& Maolagain (2000) found no significant difference between male and female growth rates. In most cases, heavy metal concentrations between male and female fish were not significantly different in this present study, in spite of physiological differences between sexes, such as sexual dimorphism in flatfish, However, a small sample size of males in this study might have caused this relationship to be undetermined.

\section{Diet}

Transfer of heavy metal contamination through diet has been considered since the 1960s (Bryan \& Darracott 1979; Karadede \& Unli 2007). The process of accumulation up the food chain is referred to as bioaccumulation. Also, metals can be biomagnified within a single species with longer and heavier individuals having higher levels of contaminants (Ribeyre et al. 1995). It has been long known in bivalves that the primary exposure route of heavy metals is through sediment (Luoma et al. 1995), whereas the primary source for fish was through diet, with laboratory studies showing little to no metals being transported through aqueous exposure (Turner \& Swick 1983). Similarly, uptake of Zn from water has been reported in multiple works to only play a minor role in uptake relative to diet in marine fishes (Wong et al. 2001).

$\mathrm{Hg}$ uptake through prey is a major route for $\mathrm{Hg}$ accumulation in marine fishes (Spry \& Weiner 1991; Havelkova et al. 2008; Bosch et al. 2016). Hg concentration in predatory fish tissues is significantly higher than non-predatory fish (Havelkova et al. 2008). Hg levels in mustelus smooth-hounds have been correlated with concentrations in higher trophic level prey, such as cephalopods (Bosch et al. 2016). Smooth-hounds broaden their prey-niche as they age, and gradually shift from small polychaetes and invertebrates to crustaceans and cephalopods (Smale \& Compagno 1997; Bosch et al. 2016). Diet has been attributed to heavy metal burden in the field, with Cd in Swordfish (X. gladius) positively correlated with Cd in their cephalopod prey (Bustamante et al. 1998; Kojadinovic et al. 2007). Bosch et al. (2016) hypothesized the unexpected lack of $\mathrm{Hg}$ correlation between muscle concentration and fish size could be due to prey composition. The small study site, Langebaan Lagoon was characterized by low 
species diversity, and stomach analysis showed smooth-hounds in the lagoon feed primarily on inshore crustaceans during their life span (Bosch et al. 2016). Stomach content analysis in New Zealand rig shark have found they are also characterized by low species diversity (Getzlaff 2012). Rig shark are opportunistic feeders that feed primarily on benthic invertebrates (Getzlaff 2012; Francis 2012a). Graham (1939) determined rig shark in Otago harbour feed on polychaetes and crustaceans, whereas Graham (1956) found rig shark in Otago Harbour feed primarily on the hairy-handed crab. Getzlaff (2012) determined the stalkeyed mud crab and hairy-handed crab made up the majority of the diet in rig shark from Porirua Harbour. Both species (stalk-eyed mud crab and hairy-handed crab were the most abundant food item in the stomach of rig sharks in Porirua Harbour during this present study. A possible hypothesis for a lack of $\mathrm{Hg}$ accumulation in muscle tissue could be because of low diversity prey items for rig shark in Porirua Harbour, much like the smooth-hound in the study undertaken by Bosch et al. (2016).

Crustaceans are typically good bioindicators of metal contamination in sediment because they feed and live among contaminated sediments (Zhao et al. 2010). Thus, studies on heavy metal concentration in crabs are crucial in understanding the relationship between dietary uptake of metals up the food web, especially in estuarine ecosystems (Zhao et al. 2010). It was found that metal accumulation in the hepatopancreas of crabs that lived in the Tigris River was positively correlated with metals found in their prey source (Karadede \& Unli 2007). The relationship between concentration in Narrow tongue-sole (Cynoglossus gracilis) and Mitten crab (Eriocheir sinensis) determined heavy metals were highest in the prey source and sediment, indicating the high levels in sediment could be the enrichment of metals in crabs (Zhao et al. 2010). Moreover, high concentrations of Cu in Malbar sole (C. macrostomus) was attributed to their feeding ecology on benthic invertebrates (Rejomon et al. 2010). However, benthic prey may represent a different bioaccumulation pattern of metals as compared to fishes (Ololade et al. 2011).

All species sampled in Porirua Harbour were benthic and demersal fish that feed on a similar food source. Therefore, it is likely to establish relationships between prey preference and corresponding heavy metal accumulation. Rig shark and rays have adapted grinding plates for crustacean prey, and flatfish are adapted to feed on benthic invertebrates and detritus (Webb 
1973; Bosch 2012), and a similarity in feeding ecology is supported by the Frequency of Occurrence (F\%) being $63 \%$ for the stalk-eyed mud crab for all fish sampled in Porirua Harbour. However, to directly determine bioaccumulation from prey to predator, studies on heavy metal in crustaceans in Porirua harbour is suggested and should be complemented with laboratory experiments.

\section{Species variation}

Variation in heavy metal concentrations between species is well established, with different ecological needs, metabolic activities, swimming behaviours and diet causing different uptake in heavy metals (Canli \& Atli 2003). Species considered ideal bio-indicators are characterized by high metabolic rates, fast growth rates, and long life cycles (Kojadinovic et al. 2007). However, the fish sampled from Porirua Harbour cover a large range of size, habitats and life cycles. These are potential factors in explaining the different concentrations of heavy metals, especially across the genus. Elasmobranchs, for example, had the highest $\mathrm{Hg}$ concentrations, and are characterized by long-life cycles which allow bioaccumulation over time. This has been reported in multiple works (Branco et al. 2007; Bosch et al. 2016).

\section{Parasites and lesions}

Parasites and lesions have been used as indicators of contaminated flatfish for decades, (Köhler 1990; Vethaak \& Jol 1996). Liver lesions have been examined in the winter flounder (P. americanus) in contaminated estuaries in the United States (Hopper et al. 1994; Khan et al. 1998), in particular, neoplasmic lesions (Chang et al. 1998; Khan \& Payne 2002). A health assessment undertaken on yellow belly flounder in Waitemata Harbour found fish collected from sites with localized heavy metal pollution had neoplasmic lesions and microscopic trichodina infestation in the gills (Nenadic 1998). There were also histopathological changes in liver and gonad tissue in yellow belly flounder collected from contaminated sites, causing positional reproductive failure or death (Nenadic 1998). There were also abnormalities in gill cells from flounder collected from polluted sites (Nenadic 1998).

Although relationships between heavy metal burden and parisites and lesions was not determined in this present study, they were still observed. Burreson et al (2008) identified 
the first endemic gill leech in New Zealand, with yellow belly flounder the host species for Leporinabdella digglesi. The unidentified gill leech found in one speckled sole matched the characteristics of $L$. digglesi, with a length of $11 \mathrm{~mm}$ including the sucker, a width of $2.0 \mathrm{~mm}$, and a wide body tapering towards a caudal sucker (Burreson et al. 2008) (Appendix C). However, formal identification of the gill leech found in this present study was not determined.

Lesions have also been identified as an indicator for heavy metal burden in elasmobranchs, although it is not as extensively covered as demersal species (Sandoval-Herrera et al. 2016). Cerebral lesions and histopathological changes have been identified in dogfish (Tort \& Torres 1988) and White sharks (Carcharodon carcharias) (Mull et al. 2012). Similarly, parasites have been identified as an indicator for heavy metal contamination in Whitecheek shark (Carcharhinus dussumieri) (Malek et al. 2007). A small sample size did not allow a relationship between parasite load and heavy metal burden to be obtained. Similarly, histopathological analysis wasn't undertaken in this present study, so it is not possible to rule out any physiological impairment heavy metals might be having on fishes in Porirua Harbour.

\section{Environmental Characteristics}

\section{Water chemistry}

Metal accumulation in marine fishes is interlinked with environmental parameters such as temperature, pH, acidification, and salinity (Pourang et al. 2005: Jezierska 2006; Rejomon et al. 2010). Multiple works indicate water acidification affects the accumulation rate of heavy metals (Jezierska 2006). Jezierska (2006) concluded that water acidification affects bioaccumulation in marine fishes by changing the solubility of heavy metals.

Accumulation of $\mathrm{Cu}$ is accelerated under lower $\mathrm{pH}$ with damaged gill epithelia becoming more permeable to a range of heavy metals (Cogun \& Kargin 2004). More directly related to estuarine ecosystems, salinity reduces the uptake of heavy metals into marine fishes (Jezierska \& Witeska 2006). Stagg \& Shuttleworth (1982) published one of the first comprehensive studies on heavy metal accumulation in flatfish. It was established that the European flounder (Platichthys flessus) had lower Cu concentrations than freshwater fish, 
which was found to be an adaptation to salinity and its associated heavy metal uptake. Kock et al. (1996) determined $\mathrm{Pb}$ and $\mathrm{Cd}$ uptake was positively correlated to water temperature, with higher absorption occurring in warmer temperatures, due to an increase in metabolic demand. However, salinity, $\mathrm{pH}$ and, water temperature and water acidification were not measured in this present study, and warrant further investigation.

\section{Site variation}

Multiple studies have found heavy metals show significant variation among regions (Canli \& Atli 2003), and within sites (Karadede \& Unli 2007). Some authors have noted differences between heavy metal concentrations in similar species from the same area (Topcuoğlu et al. 2003), which is attributed to minor site changes in chemical and physical characteristics at the sampling sites (Karadede \& Unli 2007). It is possible that such changes were present in Porirua Harbour, but were not tested for in this current study.

Oliver (2016) established that heavy metal concentrations in sediment were elevated in particular areas, especially around storm-water outlets. However, given the nature of rig shark and eagle ray only occupying the estuary during the summer before migrating to coastal waters (Francis 2012a), it is undetermined if site variation could be evident in rig shark tissues. Flatfish, although thought to be year-round residents in Porirua haven't been extensively researched and have been shown to migrate to coastal waters to spawn (Francis 2012a).

Site variation was also unable to be determined because of uneven sample sizes across species, sites, and estuary arms. More rig shark were caught in Onepoto than Pauatahanui, which contradicts earlier research (Hendry 2004; Francis 2012a). However, sampling in Pauatahanui began in April when rig are known to leave the estuary after pupping and mating (Hendry 2004; Francis 2012a). Francis (2012a) collected flatfish across both Pautahanui and Onepoto, with one of the most significant catches of yellow belly flounder being in Onepoto, whereas flounder were unable to be obtained in this present study from Onepoto. Significant differences in heavy metal accumulation in fishes have been found at the same sites in Porirua Harbour, but can largely be explained by total fish size. It is possible that sampling methods were not extensive enough to obtain a sample size from this estuary arm, but the degradation 
of Onepoto is known (Oliver 2016). Further research on flatfish in Onepoto will need to be undertaken to determine if they are still present in this estuary arm and if they are affected by heavy metal contamination.

\section{Sediment contamination}

Estuaries act as a sink for heavy metals, and as a result metal levels in sediment can be 101000 times higher than metal concentrations in the surrounding water and organisms (Zhao et al. 2010). Various investigations have found $\mathrm{Zn}$ and $\mathrm{Pb}$ are elevated in Porirua Harbour (Glasby et al. 1990; Williamson et al. 2005; Oliver 2016). However, contamination isn't uniform across sediment with the highest concentrations found in southern Onepoto, with storm-water from Porirua stream identified as the primary source (Glasby et al. 1990). In most cases, heavy metal contamination in Porirua Harbour sediments only exceeds 'early warning' guidelines by ANZECC (2000), which indicates there is an opportunity for management and intervention to limit further degradation in the harbour. However, the excess storm-water discharge has caused $\mathrm{Zn}$ to be present in Porirua Harbour sediment above quality guidelines, and $\mathrm{Pb}$ is elevated at Onepoto stream and Porirua stream in Onepoto, and Brown stream in Pauatahanui (Sorensen \& Milne 2009). Heavy metals in Porirua Harbour sediment were in the same order of magnitude as those examined in Tamaki estuary (Adrahim \& Parker 2008), and Wellington Harbour (Oliver \& Milne 2012).

Benthic detrital-feeding fishes, such as flatfish have the ability to bioaccumulate sedimentassociated metals, which may represent a long-term source of contamination since metals can be released from the sediment back into the water column (Zhao et al. 2010). Few attempts have tried to establish the relationship between the routes of transmission from metals from sediment into fishes. (Zhao et al. 2010). Bioaccumulation in tissues of demersal and benthic fish have been found to have elevated Cu concentrations (Urena et al. 2007). For instance, $\mathrm{Cu}$ concentrations in the range of this study have been observed in regions where water and sediment are enriched in this element and has been seen in India (Rejomon et al. 2010), and Western Australia (Plaskett \& Potter 1979). It is important to note that Zhao et al. (2010) found the lowest heavy metal concentrations in Narrow tongue-sole (C. gracilis) in the Yangtze estuary, and no correlations between sediment concentrations despite it being a 
demersal fish species. It was determined that this was because the sole was relatively immobile, so metals might not have the chance to accumulate in their tissues to high levels. It is also theorized that particular adaptations may allow it to regulate $\mathrm{Cu}$ concentrations at low levels (Zhao et al. 2010).

Ingestion of contaminated sediment has been identified as a primary route for $\mathrm{Zn}$ uptake to the liver in cultured fish in fish farms in Hong Kong (Wong et al. 2001). Similarly, Zn was found in highest concentration in fish tissues in the Yangtze Estuary, which was attributed to the higher bioavailability and higher $\mathrm{Zn}$ concentration in the estuarine sediment (Zhao et al. 2010). Zhao et al. (2010) established $\mathrm{Pb}$ in sediments in the Yangtze estuary was bioaccumulated in the gill tissue of the Narrow-tongue sole (C. gracilis).

However, it is important to note that sediment samples were not collected during this study and were obtained from Oliver (2016). Sediment samples were collected under different protocols and processed at a different laboratory so could yield different results than if sediment was collected in this present study. Similarly, sediment samples from Oliver (2016) were collected 2 years prior and could yield different results due to this.

\section{Seasonal variation}

Seasonal fluctuation in metal accumulation in fish tissue has been established, with metals in fish tissue found in higher concentrations in winter than in summer (Karadede \& Unli 2007). Accumulation in gill tissue is commonly used as a seasonal indicator where metal bioavailability fluctuates between wet and dry seasons (Sahal et al. 2016; D'costa et al. 2017). The proliferation of waterborne metals in wet seasons are due to an increase in industrial and agricultural runoff and has observed in the Mediterranean (Dural et al. 2007), India (Arulkumar et al. 2017), and the Middle East (Khoshnamvand 2012). Only 1 season (autumn) was reviewed in this research, and as such the influence of seasonal fluctuations could not be determined. 


\section{Maternal offloading in rig shark near-term embryos}

\section{Essential metals}

Frías-Espericueta et al. (2014) examined maternal and embryonic $\mathrm{Cu}$ concentrations in sharpnose shark (Rhizoprionodon longurio) of the same order of magnitude as this present study. However, they found a positive relationship between maternal Zn concentrations, whereas this current study found a negative relationship with $\mathrm{Zn}$. A negative relationship between heavy metals and embryo size has been observed in short-fin mako (Isurus oxyrinchus) and common thresher sharks (Alopias Vulpinus). This supports the assumption by Lyons et al. (2013) that contaminants present in embryos are a result of what they receive in utero. There was a clear negative trend as size increased in rig embryos for $\mathrm{Zn}$ and $\mathrm{Pb}$ in this present study, possibly suggesting that they have received the majority of their contaminants from their mothers, resulting in a subsequent dilution with growth (Lyons et al. 2013; Le Bourg et al. 2013). It is possible that negative relationships between essential elements in utero follow the same trend in adult fish, including within the Mustelus genus (Erasmus 2007; Bosch et al. 2016), that state relationships may be due to size-dependant variability in metabolic activity in fishes (Canli \& Atli 2003). Metabolic activity is generally higher in younger individuals and the rate of accumulation is positively correlated with metabolic rate (Kojadinovic et al. 2007). Due to this, it is theorized that younger fish will have a higher heavy metal burden than older fish (Kojadinovic et al. 2007), and may include developing embryos in utero. However, this theory would require further investigation.

Rig shark embryos had elevated levels of essential metals before parturition, which suggests maternal offloading (Lyons and Lowe 2013). However, there was no linear relationship between embryo $\mathrm{Cu}$ and mother concentration in this present study, therefore It is possible this is due to $\mathrm{Cu}$ being strictly regulated in fish tissue through homeostasis (Phillips 1980). However, literature is scarce and limited to organic pollutants such as pesticides, PCBs and non-essential heavy metals (Lyons et al. 2013; Le Bourg et al. 2013), so results could not be determined. 


\section{Non-essential metals}

Maternal offloading of $\mathrm{Hg}$ in elasmobranchs is the most documented (Adams \& McMichael 1999; Pethybridge et al. 2010; Peng et al. 2012; Lyons \& Lowe 2013a). Rig shark embryo Hg concentrations found in this study were $50 \%$ higher than those found in Leopard shark (Triakis semifasciata) and eight-times higher than Thornback guitarfish (Platyrhinoidis triseriata) (Van Hees \& Ebert 2017). However, they were in the range of $\mathrm{Hg}$ reported in Atlantic Sharpnose Shark (Rhizoprionodon terraenovae) and Bonnethead Shark (S. tiburo) (Hueter et al. 1995; Adams \& McMichael 1999). Hg concentrations were comparable to those found in other elasmobranch mother-embryo pairs, such as the common thresher shark (A. vulpinus) (Lyons \& Lowe 2013a), bull shark (Carcharhinus leucas) (Adams \& McMichael 1999), and other demersal shark species (Pethybridge et al. 2010). Our results are similar to Van Hees \& Ebert (2017) who found embryo $\mathrm{Hg}$ concentrations increased with maternal $\mathrm{Hg}$ concentrations. Similarly, embryo Hg burden increasing with embryo growth rate has been observed in the round stingray (Urobatis halleri) (Lyons \& Lowe 2013b). However, Leopard shark (T. semifasciata) and Thornback guitarfish ( $P$. triseriata) $\mathrm{Hg}$ concentrations in embryos were not comparable with mother $\mathrm{Hg}$ concentrations (Van Hees \& Ebert 2017). Frías-Espericueta et al. (2014) found maternal and embryonic Pb concentrations in sharpnose shark ( $R$. longurio) 16times higher than rig shark embryo Pb concentrations.

Maternal liver $\mathrm{Hg}$ concentration was a stronger indicator than muscle concentrations in determining embryo $\mathrm{Hg}$ concentration. Considering the liver is a known source of energy storage, especially during reproduction, the $\mathrm{Hg}$ measured in embryos is most likely derived from the liver (Bourg et al. 2013). Such findings have been found in the common thresher shark (A. vulpinus), where it is unlikely $\mathrm{Hg}$ stored in muscle tissue is transferred to embryos which would explain the higher concentrations found in mother muscle tissue (Lyons and Lowe 2013). Such results are comparable to this present study. Similarly, Lyons \& Lowe (2013) found organic contaminates in round stingray (U. halleri) embryos were derived from the mother's liver. Le Bourg et al. (2013) established a low transfer of Hg from muscle of maternal Shortnose spurdog (Squalus megalops) and small fin gulper shark (Centrophorus moluccensis). 
It has been established that $\mathrm{Hg}$ distribution among tissues is highly variable and species, trophic and maturity dependent (Bridenbaugh 2017). It is possible that other heavy metals can follow the same trend. Metal concentrations $(\mathrm{Se}, \mathrm{Hg}, \mathrm{Pb})$ in on smooth-hound (Mustelus mustelus) embryos in Angolia and had $\mathrm{Pb}$ and $\mathrm{Hg}$ concentrations 3-times lower than embryos in this present study, but the pups analyzed were from 1 litter and mother concentrations were not considered (Zaera \& Johnsen 2011).

\section{Trophic status}

In a study on trophic ecology, white sharks (C. carcharias), with higher trophic level had the highest degree of material offloading in comparison to short-fin mako (I. oxyrinchus) and common thresher sharks (A. vulpinus) (Lyon et al. 2013). Rig shark Hg concentrations in this study were considerably lower than other shark species, such as $\mathrm{Hg}$ found in blacktip sharks (Carcharhinus limbatus) which ranged from 0.63-0.73 mg/kg (Lyons et al. 2013; Bridenbaugh 2017). Such findings may be a result of rig shark sitting at a lower trophic level.

\section{Maturity}

It has been long established that like marine mammals, elasmobranchs can transfer contaminants to their young (Mull et al. 2013; Van Hees \& Ebert 2017). It has been demonstrated that females attain higher contaminant levels before maturity, and their overall contaminant burden decreases after it is transferred to their offspring in their first reproductive event (Ross et al. 2000). This phenomenon is based on the fact that species that reproduce later in life have longer to accumulate contaminants that they can offload to their offspring. Studies have found near-maturity short-fin mako sharks (I. oxyrinchus) which mature at 7-14 years had significantly higher levels of contaminants offloaded to their offspring than common thresher sharks (A. vulpinus) which mature at 5-7 years (Lyons et al. 2013). Similarly, since females must acquire heavy metal contaminants to offload them to their offspring, factors influencing bioaccumulation in females such as species, and trophic status could affect the amount offloaded to their young (Lyons et al. 2013). In this present study, muscle $\mathrm{Pb}$ concentrations were 4-times higher in pre-ovulatory females than pregnant females and might be attributed to such factors. 


\section{Reproductive mode}

Maternal offloading has been studied in placental (Adams \& McMichael 1998) and aplacental sharks (Pethybridge et al. 2010), and it has been hypothesized that maternal offloading of $\mathrm{Hg}$ is higher in placental sharks than aplacental, primarily because of the difference in reproductive mode (Le Bourg et al. 2013). Embryos in placental sharks are nourished by external yolk sac reserves and a placental resource, whereas aplacental sharks, like rig shark, are nourished by yolk sacs and no other maternal contribution (Le Bourg et al. 2013). Because rig shark are aplacental, it is possible maternal offloading of metals, particularly $\mathrm{Hg}$ and $\mathrm{Pb}$ are of lesser extent than offloading in placental species such as blacktip shark (C. limbatus), dusky shark (Carcharhinus obscurus), and Atlantic sharpnose (R. longurio) (Hueter et al. 1995; Frías-Espericueta et al. 2014; Bridenbaugh 2017). However, it is important to note that in this present study, embryonic concentrations In rig shark were also comparable with levels found in placental sharks such as bull shark (C. leucas) and bonnethead sharks (S. tiburo) (Adams \& McMichael 1999), so mechanisms behind offloading might be more complicated.

\section{Alternative routes of transfer}

During gestation, developing oocytes take up vitellogenin, a lipophosphoprotien yolk that is derived from the females liver (Hamlett 1999; Van Hees \& Ebert 2017). During this process, contaminants that bind to the vitellogenin are transferred to the embryos (Hamlett \& Koob 1999; Van Hees \& Ebert 2017). Studies have shown that Cd and Se can bind to the Vitellogenin (Gosh \& Thomas 1995), while As can reduce the production of Vitellogenin (Hwang et al. 2011). Although Cd, Se and As were not measured in this study, it is possible that other metals can contaminate the yolk, and reduce its production in rig shark embryos. Naidoo et al. (2017) looked at the first case of maternal offloading in plasma, uterine and capsule fluid in elasmobranchs, and found $\mathrm{Al}, \mathrm{As}, \mathrm{Cd}$, and Se were in high concentrations in the fluids examined.

In aplacental sharks, embryos feed on unfertilized eggs, which is a known route of uptake for contaminants (Lyons et al. 2013). Lyons and Lowe (2013) established oophagy as one of the major routes of maternal offloading, as the stomachs of thresher shark (A. Vulpinus) embryos had high levels of $\mathrm{Hg}$ present. In vitro consumption of embryos in Lamnid sharks has also been 
identified as a source for contaminants in the embryos of aplacental species (Lyons et al. 2013). Oophagy was not examined in this present study, leaving a significant route of transfer undetermined.

\section{Conclusion}

Understanding how essential $(\mathrm{Cn}, \mathrm{Zn})$ and non-essential $(\mathrm{Pb}, \mathrm{Hg})$ heavy metals accumulate in fishes is important for effective management and restoration efforts. Accumulation of heavy metals is influenced by factors such as species, age, size, and trophic level (Dural et al. 2007). In addition, heavy metals can be found in various tissue types, including muscle and liver tissue (Kalman et al. 2014).

This thesis has contributed information on the heavy metal accumulation of $\mathrm{Cu}, \mathrm{Zn}, \mathrm{Pb}$ and $\mathrm{Hg}$ in the tissue (muscle and liver) of yellow belly flounder (Pātiki, tōtara, Rhombosolea leporina), sand flounder (Pātiki, Rhombosolea plebeia), speckled sole (Peltorhamphus latus), rig shark (Pioke, Makō, Mangō, Mustelus lenticulatus), short-tailed stingray (Whai, Dasyatis brevicaudata), and eagle ray (Whai keo, Myliobatis tenuicaudatus) caught in Porirua Harbour. Heavy metal accumulation of $\mathrm{Cu}, \mathrm{Zn}, \mathrm{Pb}$, and $\mathrm{Hg}$ depended primarily on the tissue type (muscle and liver), fish size and is metal and species-specific. Negative correlations were found between muscle Cu concentrations and fish size, which is generally supported across literature (Canli \& Atli 2003; Erasmus 2007). This is due to metabolic activity being higher in younger individuals, thus the rate of muscle $\mathrm{Cu}$ concentration is positively correlated with metabolic rate (Nussy et al. 2000). Such findings indicate muscle tissue is a good indicator for $\mathrm{Cu}$ accumulation in Porirua Harbour. No significant relationships were observed with $\mathrm{Zn}$ in fish tissue, therefore It is hypothesized that individual Zn concentrations accumulate at their own rate across tissue types and across species and may not reflect the ambient levels of this metal in the environment. This is supported by research that claim $\mathrm{Zn}$ is regulated and maintained at specific levels in fishes through metabolic processes (Widianarko et al. 2000; Canli \& Atli 2003).

The only relationship established with $\mathrm{Pb}$ was in the muscle tissue of pre-ovulatory rig shark and size, but this was not seen in the liver tissue. Low levels of $\mathrm{Pb}$ accumulation was 
attributed to the lack of $\mathrm{Pb}$ binding proteins in the two tissues types studied (Daka et al. 2006; Narges et al. 2012). Fish size was the most significant indicator for $\mathrm{Hg}$ concentration in fish tissues in Porirua Harbour. $\mathrm{Hg}$ accumulation in fish muscle is the most documented, as $\mathrm{Hg}$ accumulation is positively correlated with fish size (Carvalho et al. 2005; Campbell et al. 2010).

Maternal offloading is a rarely observed phenomenon, and it has not been documented in rig shark in New Zealand. In this thesis there was no relationship for $\mathrm{Cu}$ between the amount in embryos and either the maternal concentration or size. However, $\mathrm{Zn}$ and $\mathrm{Pb}$ concentration in rig shark embryos were positively related with maternal size. Therefore, size explained embryo $\mathrm{Zn}$ and $\mathrm{Pb}$ concentration in rig shark embryos, and embryo $\mathrm{Hg}$ concentrations were explained by maternal concentrations and size, suggesting maternal offloading of $\mathrm{Hg}$ might be occurring in rig shark.

Among the fish species sampled in Porirua Harbour, rig shark, yellow belly flounder, and sand flounder have commercial value. Based on the samples collected, heavy metal concentrations in edible muscle tissue were not heavily burdened, and fell well below regulatory guidelines for New Zealand and overseas. However, two female rig shark were just below FAO (2003) guideline values of $1.00 \mathrm{mg} . \mathrm{kg}$ w.w (measuring at 0.73 and $0.84 \mathrm{mg} / \mathrm{kg} \mathrm{w.w)}$ ), and should be investigated further.

Compared to data reported from other fish species, benthic fishes from Porirua Harbour appear to exhibit similar patterns in heavy metal accumulation experienced worldwide. This research adds to the currently lacking information on heavy metal accumulation in these study species, and will aid the ongoing monitoring of Porirua Harbour by Greater Wellington Regional Council and Porirua City Council. 


\section{Recommendations for future research}

- Establish relationships between heavy metal concentration across additional tissue types in fishes in Porirua Harbour.

- Capture fishes in Porirua Harbour over multiple seasons and sites in order to determine if there is a difference in heavy metal concentration over space and time.

- Complement this present study with laboratory dosing experiments to explore accumulation, distribution, interaction and excretion of heavy metals in benthic fishes from Porirua Harbour.

- Determine heavy metal burden in crustaceans prey, in particular the stalk eyed mud crab in Porirua Harbour as it is a significant food source for benthic fishes in the region.

- Future research into the validation of elasmobranch aging, especially in stingrays, and determining heavy metal accumulation relationships with age.

- Collect sediment samples at the same time, and at the same location fishes are collected.

- future research into maternal offloading of essential heavy metals ( $\mathrm{Cu}$ and $\mathrm{Zn}$ ) to nearterm embryos in elasmobranchs.

- Establish the importance of multiple uptake routes in maternal offloading in the aplacental rig shark, especially oophagy.

- Future research on movement of fishes within Porirua Harbour to determine movement of fishes between the two estuary arms, Onepoto and Pauatahanui. 


\section{Literature cited}

Abalaka, S. E. (2015). Heavy metals bioaccumulation and histopathological changes in Auchenoglanis occidentalis fish from Tiga dam, Nigeria. Journal of Environmental Health Science and Engineering, 13(1), 67.

Abrahim, G. M. S., \& Parker, R. J. (2008). Assessment of heavy metal enrichment factors and the degree of contamination in marine sediments from Tamaki Estuary, Auckland, New Zealand. Environmental monitoring and assessment, 136(1-3), 227238.

Abreu, S. N., Pereira, E., Vale, C., \& Duarte, A. (2000). Accumulation of mercury in sea bass from a contaminated lagoon (Ria de Aveiro, Portugal). Marine Pollution Bulletin, 40(4), 293-297.

Adams, D. H., \& mcmichael Jr, R. H. (1999). Mercury levels in four species of sharks from the Atlantic coast of Florida. Fishery Bulletin, 97(2), 372-379.

Addison, R. F., \& Brodie, P. F. (1977). Organochlorine residues in maternal blubber, milk, and pup blubber from grey seals (Halichoerus grypus) from Sable Island, Nova Scotia. Journal of the Fisheries Board of Canada, 34(7), 937-941.

Akoto, O., Bismark Eshun, F., Darko, G., \& Adei, E. (2014). Concentrations and health risk assessments of heavy metals in fish from the Fosu Lagoon. International Journal of Environmental Research, 8(2), 403-410.

Al-Weher, S. M. (2008). Levels of heavy metal Cd, Cu and $\mathrm{Zn}$ in three fish species collected from the Northern Jordan Valley, Jordan. Jordan Journal of Biological Sciences, 1(1), 41-46.

Andres, S., Ribeyre, F., Tourencq, J. N., \&amp; Boudou, A. (2000). Interspecific comparison of cadmium and zinc contamination in the organs of four fish species along a polymetallic pollution gradient (Lot River, France). Science of the Total Environment, 248(1), 11-25.

Arellano, J. M., Storch, V., \& Sarasquete, C. (1999). Histological changes and copper accumulation in liver and gills of the Senegales sole, Solea Barbara Barbara Barbara senegalensis. Ecotoxicology and Environmental Safety, 44(1), 62-72.

Arulkumar, A., Paramasivam, S., \& Rajaram, R. (2017). Toxic heavy metals in commercially important food fishes collected from Palk Bay, Southeastern Barbara India. Marine Pollution Bulletin, 119(1), 454-459.

Auckland Regional Council (ARC) (2004) Blueprint for monitoring urban receiving environments. Auckland Regional Council Technical Publication No. 168 (revised), Auckland. 
Australian and New Zealand Environment and Conservation Council (2000). Australian and New Zealand guidelines for fresh and marine water quality, volume 1, the guidelines. Agriculture and Resource Management Councils of Australia and New Zealand, Canberrra.

Authman, M. M., Zaki, M. S., Khallaf, E. A., \& Abbas, H. H. (2015). Use of fish as bio-indicator of the effects of heavy metals pollution. Journal of Aquaculture Research \& Development, 6(4), 1.

Ayling, T., and G. J. Cox. 1984. Collins guide to the sea fishes of New Zealand: Collins.

Bailey, K. M. (1997). Structural dynamics and ecology of flatfish populations. Journal of Sea Research, 37(3), 269-280.

Baker, R., Buckland, A., \& Sheaves, M. (2014). Fish gut content analysis: robust measures of diet composition. Fish and Fisheries, 15(1), 170-177.

Barbara, J., Pioter, S., Małgorzata, W., \& Katarzyna, Ł. (2009). Disturbances of early development of fish caused by heavy metals (a review). Electronic Journal of Ichthyology, 2, 76-96.

Barjhoux, I., Baudrimont, M., Morin, B., Landi, L., Gonzalez, P., \& Cachot, J. (2012). Effects of copper and cadmium spiked-sediments on embryonic development of Japanese medaka (Oryzias latipes). Ecotoxicology and environmental safety, 79, 272-282.

Begum, G., Venkateswara Rao, J., \& Srikanth, K. (2006). Oxidative stress and changes in locomotor behavior and gill morphology of Gambusia affinis exposed to chromium. Toxicological \& Environmental Chemistry, 88(2), 355-365.

Benedetti, M., Fattorini, D., Martuccio, G., Nigro, M., \& Regoli, F. (2009). Interactions between trace metals $(\mathrm{Cu}, \mathrm{Hg}, \mathrm{Ni}, \mathrm{Pb})$ and 2, 3, 7, 8-tetrachlorodibenzo-p-dioxin in the antarctic fish Trematomus bernacchii: Oxidative effects on biotransformation pathway. Environmental toxicology and chemistry, 28(4), 818-825.

Berg, J. (1979). Discussion of methods of investigating the food of fishes, with reference to a preliminary study of the prey of Gobiusculus flavescens (Gobiidae). Marine biology, 50(3), 263-273.

Berg, V., Ugland, K. I., Hareide, N. R., Groenningen, D., \& Skaare, J. U. (2000). Mercury, cadmium, lead, and selenium in fish from a Norwegian fjord and off the coast, the importance of sampling localitypresented at QUASIMEME-QUASH 1999, Egmondaan Zee, The Netherlands, October 6-9, 1999. Journal of Environmental Monitoring, 2(4), 375-377.

Bloom, N. S. (1992). On the chemical form of mercury in edible fish and marine invertebrate tissue. Canadian journal of fisheries and aquatic sciences, 49(5), 1010-1017. 
Boening, D. W. (2000). Ecological effects, transport, and fate of mercury: a general review. Chemosphere, 40(12), 1335-1351.

Bolger. T, C. P. L. (2013). Acetylcholinesterase, glutathione and hepatosomatic index as potential biomarkers of sewage pollution and depuration in fish. Marine Pollution Bulletin, 74(1), 183-186.

Borrell A., Bloch D., \& Desportes, G. (1995). Age trends and reproductive transfer of organochlorine compounds in long-finned pilot whales from the Faroe Islands. Environmental Pollution, 88, 283-292.

Bosch, A. C. (2012). Investigation of the chemical composition and nutritional value of smooth-hound shark (Mustelus mustelus) meat (Doctoral dissertation, Stellenbosch: Stellenbosch University).

Bosch, A. C., O'Neill, B., Sigge, G. O., Kerwath, S. E., \& Hoffman, L. C. (2016). Heavy metals in marine fish meat and consumer health: a review. Journal of the Science of Food and Agriculture, 96(1), 32-48.

Bosch, A. C., Sigge, G. O., Kerwath, S. E., Cawthorn, D. M., \& Hoffman, L. C. (2013). The effects of gender, size and life-cycle stage on the chemical composition of smooth-

hound shark (Mustelus mustelus) meat. Journal of the Science of Food and Agriculture, 93(10), 2384-2392.

Bradley, M., Barst, B., \& Basu, N. (2017). A review of mercury bioavailability in humans and fish. International journal of environmental research and public health, 14(2), 169.

Branco, V., Vale, C., Canário, J., \& dos Santos, M. N. (2007). Mercury and selenium in blue shark (Prionace glauca, L. 1758) and swordfish (Xiphias gladius, L. 1758) from two areas of the Atlantic Ocean. Environmental Pollution, 150(3), 373-380.

Bremner, I. (1991). [66] Metallothionein and copper metabolism in liver. Methods in enzymology, 205, 584-591.

Bridenbaugh, S. N. (2017). The Hematological and Histological Effects of Maternal Offloading of Mercury in Neonatal and Juvenile Blacktip Sharks (Carcharhinus limbatus) (Doctoral dissertation, Florida Gulf Coast University).

Brooks, PR., Rumsey, D. (1974). Heavy metals in some New Zealand commercial sea fishes. Offloading of Mercury in Neonatal and Juvenile Blacktip Sharks (Carcharhinus New Zealand Journal of Marine and Freshwater Research 8, 155-166.

Bruening, R. C., Oltz, E. M., Furukawa, J., Nakanishi, K., \& Kustin, K. (1985). Isolation and structure of tunichrome B-1, a reducing blood pigment from the tunicate Ascidia nigra (Linnaeus). Journal of the American Chemical Society, 107(18), 5298-5300. 
Bryan, G. W., \& Darracott, A. (1979). Bioaccumulation of marine pollutants. Phil. Trans. $R$. Soc. Lond. B, 286(1015), 483-505.

Burger, J., \& Gochfeld, M. (2004). Mercury in canned tuna: white versus light and temporal variation. Environmental research, 96(3), 239-249.

Burger, J., Jeitner, C., Donio, M., Pittfield, T., \& Gochfeld, M. (2013). Mercury and selenium levels, and selenium: mercury molar ratios of brain, muscle and other tissues in bluefish (Pomatomus saltatrix) from New Jersey, USA. Science of the total environment, 443, 278-286.

Burreson, E. M., \& Williams, J. I. (2008). Two new genera and three new species of leeches (Hirudinida: Piscicolidae) from New Zealand marine fishes. New Zealand Journal of Marine and Freshwater Research, 42(4), 379-387.

Bury, N. R., Jie, L., Flik, G., Lock, R. A., \& Bonga, S. E. W. (1998). Cortisol protects against copper induced necrosis and promotes apoptosis in fish gill chloride cells in vitro. Aquatic Toxicology, 40(2),193-202.

Bury, N. R., Walker, P. A., \& Glover, C. N. (2003). Nutritive metal uptake in teleost fish. Journal of experimental biology, 206(1), 11-23.

Bustamante, P., Bocher, P., Cherel, Y., Miramand, P., \& Caurant, F. (2003). Distribution of trace elements in the tissues of benthic and pelagic fish from the Kerguelen Islands. Science of the total environment, 313(1-3), 25-39.

Bustamante, P., Caurant, F., Fowler, S. W., \& Miramand, P. (1998). Cephalopods as a vector for the transfer of cadmium to top marine predators in the north-east Atlantic Ocean. Science of the Total Environment, 220(1), 71-80.

Cahide, C. Y., \& Ismen, A. (2016). Age and Growth of Spiny Dogfish Squalus acanthias (Squalidae: Chondrichthyes) in the North Aegean Sea. Pakistan Journal of Zoology, 48(4).

Campana, S. E., \& Jones, C. M. (1992). Analysis of otolith microstructure data. Otolith microstructure examination and analysis. Edited by DK Stevenson and SE Campana. Can. Spec. Publ. Fish. Aquat. Sci, 117, 73-100.

Campbell, L. M., Balirwa, J. S., Dixon, D. G., \& Hecky, R. E. (2004). Biomagnification of mercury in fish from Thruston Bay, Napoleon Gulf, Lake Victoria (East Africa). African Journal of Aquatic Science, 29(1), 91-96.

Canli, M., \& Atli, G. (2003). The relationships between heavy metal ( $\mathrm{Cd}, \mathrm{Cr}, \mathrm{Cu}, \mathrm{Fe}, \mathrm{Pb}, \mathrm{Zn}$ ) levels and the size of six Mediterranean fish species. Environmental pollution, 121(1), 129-136. 
Carvalho, M. L., Pereira, R. A., \& Brito, J. (2002). Heavy metals in soft tissues of Tursiops truncatus and Delphinus delphis from west Atlantic Ocean by X-ray spectrometry. Science of the total environment, 292(3), 247-254.

Carvalho, M. L., Santiago, S., \& Nunes, M. L. (2005). Assessment of the essential element and heavy metal content of edible fish muscle. Analytical and Bioanalytical Chemistry, 382(2), 426-432.

Castro-González, M. I., \& Méndez-Armenta, M. (2008). Heavy metals: Implications associated to fish consumption. Environmental toxicology and pharmacology, 26(3), 263-271.

Celik, U., \& Oehlenschläger, J. (2004). Determination of zinc and copper in fish samples collected from Northeast Atlantic by DPSAV. Food Chemistry, 87(3), 343-347.

Chan, KM. (1995). Concentrations of copper, zinc, cadmium and lead in rabbitfish (Siganus oramin) collected in Victoria Harbour, Hong Kong. Marine Pollution Bulletin, 31, 277280.

Chang, S., Zdanowicz, V. S., \& Murchelano, R. A. (1998). Associations between liver lesions in winter flounder (Pleuronectes americanus) and sediment chemical contaminants from north-east United States estuaries. ICES Journal of Marine Science, 55(5), 954 969.

Chen, P. J., Tan, S. W., \& Wu, W. L. (2012). Stabilization or oxidation of nanoscale zerovalent iron at environmentally relevant exposure changes bioavailability and toxicity in medaka fish. Environmental science \& technology, 46(15), 8431-8439.

Chu, K. W., \& Chow, K. L. (2002). Synergistic toxicity of multiple heavy metals is revealed by a biological assay using a nematode and its transgenic derivative. Aquatic Toxicology, 61(1-2), 53-64.

Clearwater, S. J., Farag, A. M., \& Meyer, J. S. (2002). Bioavailability and toxicity of dietborne copper and zinc to fish. Comparative Biochemistry and Physiology Part C: Toxicology \& Pharmacology, 132(3), 269-313.

Cloern, J. E., Abreu, P. C., Carstensen, J., Chauvaud, L., Elmgren, R., Grall, J., \& Xu, J. (2016). Human activities and climate variability drive fast-paced change across the world's estuarine-coastal ecosystems. Global Change Biology, 22(2), 513-529.

Cogun, H. Y. And Kargin, F. (2004). Effects of pH on the mortality and accumulation of copper in tissues of Oreochromis niloticus. Chemosphere, 55, 277-282.

Coleman, J.A. (1974). Growth of two species of flounders in the hauraki gulf, New Zealand. New Zealand Journal of Marine and Freshwater Research, 8:2, 351-370. 
D'Costa, A., Shyama, S. K., \& Kumar, M. P. (2017). Bioaccumulation of trace metals and total petroleum and genotoxicity responses in an edible fish population as indicators of marine pollution. Ecotoxicology and Environmental Safety, 142, 22-28.

Daka, E. R., Ifidi, I., \& Braide, S. A. (2006). Accumulation of heavy metals from single and mixed metal solutions by the gastropod mollusc Tympanotonus fuscatus Linnaeus from a Niger Delta estuary: Implications for biomonitoring. African Journal of Biotechnology, 5(20).

Dallinger, R., Prosi, F., Segner, H., \& Back, H. (1987). Contaminated food and uptake of heavy metals by fish: a review and a proposal for further research. Oecologia, 73(1), 91- 98.

Dang, F., \& Wang, W. X. (2009). Assessment of tissue-specific accumulation and effects of cadmium in a marine fish fed contaminated commercially produced diet. Aquatic Toxicology, 95(3), 248-255.

Demski, L. S., \& Wourms, J. P. (Eds.). (2013). The reproduction and development of sharks, skates, rays and ratfishes (Vol. 14). Springer Science \& Business Media.

Diggles, B. K., Smith, M., Morrison, M., Mills, G., Hine, P. M., \& Bull, B. (2000). Final report on parasites and pathological lesions of yellow-belly flounder Rhombosolia leporina and their relationship with contamination in manukau harbour. $A R C$ Technical Publication TP140. Auckland Regional Council,Auckland.

DOH S. A. D. O. H. (2004). "Foodstuffs, cosmetics and Disinfectants act, 1972 (Act no. 54 o 1972). Government gazetteno.R. 500:4-6.".

Duffy, C.A.J., Paul, L.J. \& Chin, A. 2016. Bathytoshia brevicaudata. The IUCN Red List of Threatened Species 2016:

e.T41796A68618154. Http://dx.doi.org/10.2305/IUCN.UK.2016

1.RLTS.T41796A68618154.en.

Dural, M., Göksu, M. Z. L., \& Özak, A. A. (2007). Investigation of heavy metal levels in economicallyimportant fish species captured from the Tuzla lagoon. Food chemistry, 102(1), 415-421.

Duran, S., Tunçsoy, M., Yeşilbudak, B., Ay, Ö., Cicik, B., \& Erdem, C. (2015). Metal accumulation in various tissues of Clarias gariepinus exposed to copper, zinc, cadmium and lead singly and in mixture. Fresenius Environmental Bulletin, 24(12c), 4738-4742.

El-Moselhy, K. M., Othman, A. I., El-Azem, H. A., \& El-Metwally, M. E. A. (2014). Bioaccumulation of heavy metals in some tissues of fish in the Red Sea, Barbara Egypt. Egyptian Journal of Basic and Applied Sciences, 1(2), 97-105.

Elnabris, K. J., Muzyed, S. K., \& El-Ashgar, N. M. (2013). Heavy metal concentrations in some commercially important fishes and their contribution to heavy metals exposure in 
Palestinian people of Gaza Strip (Palestine). Journal of the Association of Arab Universities for Basic and Applied Sciences, 13(1), 44-51.

Endo, T., Kimura, O., Ohta, C., Koga, N., Kato, Y., Fujii, Y., \& Haraguchi, K. (2016). Metal concentrations in the liver and stable isotope ratios of carbon and nitrogen in the muscle of silvertip shark (Carcharhinus albimarginatus) culled off Ishigaki Island, Japan: changes with growth. Plos one, 11(2), e0147797.

EOS Ecology Report No: 08002-ENV01-04 | May 2015 Prepared for: Environment Canterbury

Erasmus, C. P. (2007). The concentration of ten metals in the tissues of shark species squalus megalops and mustelus mustelus (chondrichthyes) occuring along the southerneastern coast of South Africa (Doctoral dissertation).

Escobar-Sánchez, O., Ruelas-Inzunza, J., Patrón-Gómez, J. C., \& Corro-Espinosa, D. (2014). Mercury levels in myliobatid stingrays (Batoidea) from the Gulf of California: tissue distribution and health risk assessment. Environmental monitoring and assessment, 186(3), 1931-1937.

FAO, U. F. A. A. O. (2003). " Heavy Metals Regulations Legal Notice No 66/2003.".

Farkas, A., Salánki, J., \& Specziár, A. (2003). Age-and size-specific patterns of heavy metals in the organs of freshwater fish Abramis brama L. Populating a low-contaminated site. Water research, 37(5), 959-964.

Farrell, A. P., Wood, C. M., \& Brauner, C. J. (2012). Homeostasis and toxicology of nonessential metals.

Food Standards Australia New Zealand (FSANZ). (2015). Australia New Zealand Food Standards Code - Standard 1.4.1 - Contaminants and Natural Toxicants (Incorporating amendments up to and including Amendment No. 152). Anstat Pty Ltd., Melbourne.

Francis, M. P. (2012). Fish resources of Porirua Harbour. Review of existing information and development of a survey design. Prepared for Ngati Toa. NIWA project NGA12301. NIWA Client Report WLG2012-66. Retrieved from Francis, M.P. (2012a). Fish resources of Porirua Harbour. Review of existing information and development of a survey design. Prepared for Ngati Toa. NIWA project NGA12301. NIWA Client Report WLG2012-66. 18.

Francis, M. P. (2012b). Coastal Fishes of New Zealand, $4^{\text {th }}$ Edition. Craig Potton Publishing, Neslon, New Zealand, 268. Health Science and Engineering, 13(1), 67.

Francis, M. P., \& Francis, R. I. C. C. (1992). Growth rate estimates for New Zealand rig (Mustelus lenticulatus). Marine and Freshwater Research, 43(5), 1157-1176.

Francis, M. P., \& Maolagáin, C. Ó. (2000). Age, growth and maturity of a New Zealand endemic shark (Mustelus lenticulatus) estimated from vertebral bands. Marine and Freshwater Research, 51(1), 35-42. 
Francis, M.P. (2012a). Coastal Fishes of New Zealand, 4th edition. Craig Potton Publishing, Nelson, New Zealand. 268.

Francis, M.P., Francis, R.I.C.C. (1992). Growth rate estimates for New Zealand rig (Mustelus lenticulatus). Australian Journal of Marine and Freshwater Research, 43, 1157-1176.

Francis, M.P., Lyon, W., Jones, E., Notman, P., Parkinson, D., Getzlaff, C. (2012). Rig nursery grounds in New Zealand: a review and survey. New Zealand Aquatic Environmentand Biodiversity Report 95, 50.

Francis, M.P., Morrison, M.A., Leathwick, J., \& Walsh, C. (2011). Predicting patterns of richness, occurrence and abundance of small fish in New Zealand estuaries. Marine and Freshwater Research 62: 1327-1341.

Frías-Espericueta, M. G., Cardenas-Nava, N. G., Márquez-Farías, J. F., Osuna-López, J. I., Muy-Rangel, M. D., Rubio-Carrasco, W., \& Voltolina, D. (2014). Cadmium, copper, lead and zinc concentrations in female and embryonic pacific sharpnose shark (Rhizoprionodon longurio) tissues. Bulletin of environmental contamination and toxicology, 93(5), 532-535.

Frisk, M. G., \& Miller, T. J.(2009). Maturation of little skate and winter skate in the western Atlantic from Cape Hatteras to Georges Bank. Marine and Coastal Fisheries: Dynamics, Management, and Ecosystem Science, 1(1), 1-11.

Gardner, M. G., and R. D. Ward. (2002). Taxonomic affinities within Australian and New Zealand Mustelus sharks (Chondrichthyes: Triakidae) inferred from allozymes, mitochondrial DNA and precaudal vertebrae counts. Copeia 2002, (2), 356-363.

Gašpić, Z. K., Zvonarić, T., Vrgoč, N., Odžak, N., \& Barić, A. (2002). Cadmium and lead in selected tissues of two commercially important fish species from the Adriatic Sea. Water Research, 36(20), 5023-5028.

Gelsleichter J, Walker CJ (2010) Pollutant exposure and effects in sharks and their relatives. In: Carrier JC, Musick JA, Heithaus MR (eds) Sharks and their relatives II: biodiversity, adaptive physiology, and conservation. CRC Press, Boca Raton, $p p$ 491-537

George SG, Olsson PE (1994) Metallothioneins as indicators of trace metal pollution. In: Kramer KJM (ed) Biomonitoring of coastal waters and estuaries. CRC Press, Boca Raton, FL p 151

Getzlaff, C. (2012). Diet and foraging behaviour of juvenile rig (Mustelus lenticulatus) from New Zealand harbours and estuaries. M.Sc. Thesis. Massey University, Palmerston North. 102 p. 
Ghosh, P., Thomas, P. (1995). Binding of metals to red drum vitellogenin and incorporation into oocytes. Marine Environmental Research, 39, 165-168.

Glasby, G. P., Moss, R. L., \& Stoppers, P. (1990). Heavy-metal pollution in Porirua Harbour, New Zealand.

Glasby, G. P., Stoppers, P., Walter, P., Davis, K. R., \& Renner, R. M. (1988). Heavy-metal pollution in Manukau and Waitemata harbours, New Zealand. New Zealand journal of marine and freshwater research, 22(4), 595-611.

Graham, D. H. (1939). Food of the fishes of Otago Harbour and adjacent sea. Royal Society of New Zealand.

Graham, D. H. (1956). A treasury of New Zealand fishes, 2nd edn Wellington. New Zealand: $A H$ and $A W$ Reed.

Green, M., Stevens, L., and Oliver, MD. (2014). Te Awarua-o-Porirua Harbour and catchment sediment modelling: Development and application of the CLUES and Source-to-Sink models. Greater Wellington Regional Council, Publication No. GW/ESCI-T-14/132, Wellington.

Guirlet, E., Das, K., \& Girondot, M. (2008). Maternal transfer of trace elements in leatherback turtles (Dermochelys coriacea) of French Guiana. Aquatic Toxicology, 88(4), 267-276.

Guo, Z., Zhang, W., Du, S., Green, I., Tan, Q., \& Zhang, L. (2016). Developmental patterns of copper bioaccumulation in a marine fish model Oryzias melastigma. Aquatic Toxicology, 170, 216-222.

Hamlett, W. C. (Ed.). (1999). Sharks, skates, and rays: the biology of elasmobranch fishes. JHU Press.

Hamlett, W.C. (2005). Reproductive Biology and Phylogeny of Chondrichthyes: Sharks, Batoids and Chimaeras. Science Publishers Inc., New Hampshire.

Harris, H. H., Pickering, I. J., \& George, G. N. (2003). The chemical form of mercury in fish. Science, 301(5637), 1203-1203.

Hassaninezhad, L., Safahieh, A., Salamat, N., Savari, A., \& Majd, N. E. (2014). Assessment of gill pathological responses in the tropical fish yellowfin seabream of Persian Gulf under mercury exposure. Toxicology Reports, 1, 621-628.

Havelková, M., Dušek, L., Némethová, D., Poleszczuk, G., \& Svobodová, Z. (2008). Comparison of mercury distribution between liver and muscle-a biomonitoring of fish from lightly and heavily contaminated localities. Sensors, 8(7), 4095-4109. 
Healy, W. B. (1980). Pautahanui inlet - an environmental study. DSIR information series No. 141. 19.

Hemelmad, J., Kleinveld, HA., deross, AM., Holwerda, DA., d Zandee, DI. (1987). Cadmium kinetics in freshwater clams. III. Effects of zinc on uptake and distribution of cadmium in Anadonta cygnea. Bulletin of Environmental Contamination and Toxicology, 1, 95-101.

Hendry, R.T. (2004). An assessment of the spatial extent and relative importance of nurseries, and of the genetic structure among nurseries of rig (Mustelus lenticulatus), an endemic New Zealand shark. Msc. Victoria University of Wellington, Wellington. $210 \mathrm{p}$.

Honda, K., Sahrul, M., Hidaka, H., \& Tatsukawa, R. (1983). Organ and tissue distribution of heavy metals, and their growth-related changes in Antarctic fish, Pagothenia borchgrevinki. Agricultural and Biological Chemistry, 47(11), 2521-2532.

Hooper, D.E., R., Lee, E. M., Ryan, K., \& Nag, K. (1994). Histopathology in winter flounder (Pleuronectes americanus) living adjacent to a pulp and paper mill. Archives of environmental contamination and toxicology, 26(1), 95-102.

Hou, J. L., Zhuang, P., Zhang, L. Z., Feng, L., Zhang, T., Liu, J. Y., \& Feng, G. P. (2011). Morphological deformities and recovery, accumulation and elimination of lead in body tissues of Chinese sturgeon, Acipenser sinensis, early life stages: a laboratory study. Journal of applied ichthyology, 27(2), 514-519.

Hueter, R. E., Fong, W. G., Henderson, G., French, M. F., \& Manire, C. A. (1995). Methylmercury concentration in shark muscle by species, size and distribution of sharks in Florida coastal waters. Water, Air, and Soil Pollution, 80(1-4), 893-899.

Hwang, UK., Kang, HS., Lee, Y., Shon, JK. (2011). Aluminum inhibits vitellogenin production via toxic effects on hepatocytes in the rockfish Sebastes schlegelii. Fisheries and Aquatic Sciences, 14, 355-361.

ICES. (2010). Report of the Workshop on Sexual Maturity Staging of Elasmobranches (WKMSEL). 11-14 December 2012, Lisbon, Portugal., ICES CM 2012/ACOM:59., 66.

Ikemoto, T., Kunito, T., Tanaka, H., Baba, N., Miyazaki, N., \& Tanabe, S. (2004). Detoxification mechanism of heavy metals in marine mammals and seabirds: interaction of selenium with mercury, silver, copper, zinc, and cadmium in liver. Archives of Environmental Contamination and Toxicology, 47(3), 402-413.

Islam, M. S., Ahmed, M. K., Raknuzzaman, M., Habibullah-Al-Mamun, M., \& Islam, M. K. (2015). Heavy metal pollution in surface water and sediment: a preliminary assessment of an urban river in a developing country. Ecological Indicators, 48, 282 291. 
Jones, J. B., \& Hadfield, J. D. (1985). Fishes from Porirua and Pauatahanui Inlets: occurrence in gill nets. New Zealand journal of marine and freshwater research, 19(4), 477-484.

Jawad, L. A. (2014). A case of partial albinism in the yellow-belly flounder, Rhombosolealeporina GÜNTHER, 1862

(Pleuronectiformes: Pleuronectidae) collected from Manukau Harbour, Auckland, New Zealand. Journal of Zoology, 144(1), 15-19.

JECFA (Joint FAO/WHO Expert Committee on Food Additives) (2003). Summary and conclusions of the sixtyfirst meeting of the Joint FAO/WHO Expert Committee on Food Additives (JECFA), pp. 18-22.

Jezierska, B., \& Witeska, M. (2001). Metal toxicity to fish. University of Podlasie. Monografie No. 42.

Jezierska, B., \& Witeska, M. (2006). The metal uptake and accumulation in fish living in polluted waters. Soil and water pollution monitoring, protection and remediation, 107-114.

Jezierska, B., and Witeska, M., (2001). Metal Toxicity to Fish, Wydawnictwo Akademii Podlaskiej. Siedlce, 318- 330.

Kalman, J., Smith, B. D., Bury, N. R., \& Rainbow, P. S. (2014). Biodynamic modelling of the bioaccumulation of trace metals ( $\mathrm{Ag}, \mathrm{As}$ and $\mathrm{Zn}$ ) by an infaunal estuarine invertebrate, the clam Scrobicularia plana. Aquatic toxicology, 154, 121-130.

Kaneko, J. J., \& Ralston, N. V. (2007). Selenium and mercury in pelagic fish in the central north Pacific near Hawaii. Biological trace element research, 119(3), 242-254.

Karadede-Akin, H., \& Ünlü, E. (2007). Heavy metal concentrations in water, sediment, fish and some benthic organisms from Tigris River, Turkey. Environmental Monitoring and Assessment, 131(1-3), 323-337.

Kargın, F., \& Çoğun, H. Y. (1999). Metal interactions during accumulation and elimination of zinc and cadmium in tissues of the freshwater fish Tilapia nilotica. Bulletin of environmental contamination and toxicology, 63(4), 511-519.

Kennedy, C. J. (2011). TOXICOLOGY| The Toxicology of Metals in Fishes.

Khaled A. (2004). Heavy metal concentrations in certain tissues of five commercially important fishes from El-Mex Bay, Al-Exandria. Egypt, 1- 11.

Khan, R. A., \& Payne, J. F. (2002). Some factors influencing EROD activity in winter flounder (Pleuronectes americanus) exposed to effluent from a pulp and paper mill. Chemosphere, 46(2), 235-239. 
Khan, R. A., Barker, Malek, M., Haseli, M., Mobedi, I., Ganjali, M. R., \& Mackenzie, K. (2007). Parasites as heavy metal bioindicators in the shark Carcharhinus dussumieri from the Persian Gulf. Parasitology, 134(7), 1053-1056.

Khangarot, B. S., \& Ray, P. K. (1987). Correlation between heavy metal acute toxicity values in Daphnia magna and fish. Bulletin of environmental contamination and toxicology, 38(4), 722-726.

Khoshnamvand, M., \& Kaboodvandpour, S. (2012). Assessment of total mercury bioaccumulation in white and red muscle and liver tissues of Cyprinus carpio collected from Sanandaj Gheshlagh Reservoir. ISFJ, 21(1), 79-88.

Klaverkamp, J. F., Hodgins, D. A., \& Lutz, A. (1983). Selenite toxicity and mercury-selenium interactions in juvenile fish. Archives of environmental contamination and toxicology, 12(4), 405-413.

Kock, G., Triendl, M., and Hofer, R. (1996). Seasonal patterns of metal accumulation in Arctic char (Salvelinus alpinus) from an oligotrophic Alpine lake related to temperature, Canadian Journal of Fisheries and Aquatic Sciences, 53, 780-786.

Köhler, A. (1990). Identification of contaminant-induced cellular and subcellular lesions in the liver of flounder (Platichthys flesus L.) Caught at differently polluted estuaries. Aquatic Toxicology, 16(4), 271-293.

Kojadinovic, J., Potier, M., Le Corre, M., Cosson, R. P., \& Bustamante, P. (2007). Bioaccumulation of trace elements in pelagic fish from the Western Indian Ocean. Environmental pollution, 146(2), 548-566.

Krishnamurti, A. J., \& Nair, V. R. (1999). Concentration of metals in fishes from Thane and Bassein creeks of Bombay, India.

Kureishy, T. W. (1993). Concentration of heavy metals in marine organisms around Qatar before and after the Gulf War oil spill. Marine Pollution Bulletin, 27, 183-186.

Kyne, P.M. 2016. Myliobatis tenuicaudatus. The IUCN Red List of Threatened Species 2016: e.T70686656A70687032. Http://dx.doi.org/10.2305/IUCN.UK.2016 1.RLTS.T70686656A70687032.en.

Last, P., Naylor, G., Séret, B., White, W., de Carvalho, M., \& Stehmann, M. (Eds.). (2016). Rays of the World. Csiro Publishing.

Le Bourg, B., Kiszka, J., \& Bustamante, P. (2014). Mother-embryo isotope ( $\delta 15 n, \delta 13 c)$ fractionation and mercury $(\mathrm{Hg})$ transfer in aplacental deep-sea sharks. Journal of fish biology, 84(5), 1574-1581. 
Le Port, A. (2009). Phylogenetics, phylogeography and behavioural ecology of short-tailed (Dasyatis brevicaudata) and longtail (D. Thetidis) stingrays (Doctoral dissertation, researchspace@ Auckland).

Le Port, A., \& Lavery, S. (2011). Population structure and phylogeography of the short-tailed stingray, Dasyatis brevicaudata (Hutton 1875), in the Southern Hemisphere. Journal of Heredity, 103(2), 174-185.

Le Port, A., Lavery, S., \& Montgomery, J. C. (2012). Conservation of coastal stingrays: seasonal abundance and population structure of the short-tailed stingray Dasyatis brevicaudata at a Marine Protected Area. ICES Journal of Marine Science, 69(8), 1427-1435.

Le Port, A., Sippel, T., \& Montgomery, J. C. (2008). Observations of mesoscale movements in the short-tailed stingray, Dasyatis brevicaudata from New Zealand using a novel PSAT tag attachment method. Journal of Experimental Marine Biology and Ecology, 359(2), 110-117.

Lemes, M., \& Wang, F. (2009). Methylmercury speciation in fish muscle by HPLC-ICP-MS following enzymatic hydrolysis. Journal of Analytical Atomic Spectrometry, 24(5), 663-668.

Leung, H. M., Leung, A. O. W., Wang, H. S., Ma, K. K., Liang, Y., Ho, K. C., \& Yung, K. K. L. (2014). Assessment of heavy metals/metalloid (As, Pb, Cd, Ni, Zn, Cr, Cu, Mn) concentrations in edible fish species tissue in the Pearl River Delta (PRD), China. Marine pollution bulletin, 78(1-2), 235-245.

Liu, C., Huang, HJ., Wang, HC., Chung, PY., Huang, KH. (1996). Liver metallothionein level and metal content in fish of Chung-Kung Stream, Taiwan-tilapia and Liza macrolepsis. Chemical Ecology, 12, 125-134.

Luoma, S. N., Ho, Y. B., \& Bryan, G. W. (1995). Fate, bioavailability and toxicity of silver in estuarine environments. Marine Pollution Bulletin, 31(1-3), 44-54.

Lyons, K., Lowe, C. (2013a). Mechanisms of maternal transfer of organochlorine contaminants and mercury in the common thresher shark (Alopias vulpinus). Canadian Journal of Fisheries and Aquatic Sciences, 70,1667-1672.

Lyons, K., \& Lowe, C. G. (2013b). Quantification of maternal offloading of organic contaminants in elasmobranchs using the histotrophic round stingray (Urobatis halleri) as a model. Environmental science \& technology, 47(21), 12450-12458.

Lyons, K., Carlisle, A. B., \& Lowe, C. G. (2017). Influence of ontogeny and environmental exposure on mercury accumulation in muscle and liver of male Round Stingrays. Marine environmental research, 130, 30-37.

Lyons, K., Carlisle, A., Preti, A., Mull, C., Blasius, M., O'Sullivan, J., \& Lowe, C. G. (2013). Effects of trophic ecology and habitat use on maternal transfer of contaminants in 
four species of young of the year lamniform sharks. Marine environmental research, 90, 27-38.

Macdonald, D. D., Ikonomou, M. G., Rantalaine, A. L., Rogers, I. H., Sutherland, D., \& Van Oostdam, J. (1997). Contaminants in white sturgeon (Acipenser transmontanus) from the upper Fraser River, British Columbia, Canada. Environmental toxicology and chemistry, 16(3), 479-490.

Maršálek, P., Svobodová, Z., Randák, T., \& Švehla, J. (2005). Total mercury and methylmercury contamination of fish from the Skalka reservoir: a case study. Acta Veterinaria Brno, 74(3), 427-434.

Martinez, E. A., Moore, B. C., Schaumloffel, J., \& Dasgupta, N. (2002). The potential association between menta deformities and trace elements in Chironomidae Barbara (Diptera) taken from a heavy metal contaminated river. Archives of Environmental Contamination and Toxicology, 42(3), 286-291.

Martoja, R. (1980). Identification of tiemannite as a probable product of demethylation of mercury by selenium in cetaceans: a complement to the scheme of the biological cycle of mercury. Vie Milieu, 30, 7-10.

Mathews, T., \& Fisher, N. S. (2009). Dominance of dietary intake of metals in marine elasmobranch and teleost fish. Science of the Total Environment, 407(18), 5156 5161.

Mckinley, A. C., Miskiewicz, A., Taylor, M. D., \& Johnston, E. L. (2011). Strong links between metal contamination, habitat modification and estuarine larval fish Barbara distributions. Environmental Pollution, 159(6), 1499-1509.

Mendil, D., Ünal, Ö. F., Tüzen, M., \& Soylak, M. (2010). Determination of trace metals in different fish species and sediments from the River Yeşilırmak in Tokat, Turkey. Food and Chemical Toxicology, 48(5), 1383-1392.

Mille, T., Mahe, K., Villanueva, M. C., De Pontual, H., \& Ernande, B. (2015). Sagittal otolith morphogenesis asymmetry in marine fishes. Journal of fish biology, 87(3), 646-663.

Miller, P. A., Munkittrick, K. R., \& Dixon, D. G. (1992). Relationship between concentrations of copper and zinc in water, sediment, benthic invertebrates, and tissues of white sucker (Catostomus commersoni) at metal-contaminated sites. Canadian Journal of Fisheries and Aquatic Sciences, 49(5), 978-984.

Mongillo, T. M., Holmes, E. E., Noren, D. P., vanblaricom, G. R., Punt, A. E., Neill, S. M., \& Ross, P. S. (2012). Predicted polybrominated diphenyl ether (PBDE) and polychlorinated biphenyl (PCB) accumulation in southern resident killer whales. Marine Ecology Progress Series, 453, 263-277. 
Monteiro, S. M., dos Santos, N. M., Calejo, M., Fontainhas-Fernandes, A., \& Sousa, M. (2009). Copper toxicity in gills of the teleost fish, Oreochromis niloticus: effects in apoptosis induction and cell proliferation. Aquatic toxicology, 94(3), 219-228.

Ministry of Fisheries .(2018). Fisheries infosite, rig shark [Press Release]. Retrieved from https://fs.fish.govt.nz/Page.aspx?pk=7\&tk=100\&sc=SPO\%209.

Morel, F. M., Kraepiel, A. M., \& Amyot, M. (1998). The chemical cycle and bioaccumulation of mercury. Annual review of ecology and systematics, 29(1), 543-566.

Mull, C. G., Blasius, M. E., O'Sullivan, J. B., \& Lowe, C. G. (2012). Heavy metals, trace elements, and organochlorine contaminants in muscle and liver tissue of juvenile White Sharks, Carcharodon carcharias, from the Southern California Bight. Global perspectives on the biology and life history of the White Shark. CRC Press, Boca Raton, Florida, 59-75.

Mull, C. G., Lyons, K., Blasius, M. E., Winkler, C., O’Sullivan, J. B., \& Lowe, C. G. (2013). Evidence of maternal offloading of organic contaminants in white sharks (Carcharodon carcharias). Plos one, 8(4), e62886.

Munroe, T. 2016. Peltorhamphus latus. The IUCN Red List of Threatened Species 2016: e.T69779346A69782032

Muscatello, J. R., \& Janz, D. M. (2009). Selenium accumulation in aquatic biota downstream of a uranium mining and milling operation. Science of the total environment, 407(4), 1318-1325.

Myers, MS., Stehr, CM., Olson, OP., Johnston, LL., mccain, BB., Chan, SL., Varanasi, U. (1980). Relationships between toxicopathic hepatic lesions and exposure to chemical contaminants in English sole (Pleuronecies vetulus), starry flounder (Platichthys stellatus) and white croaker (Genyonemus lineatus) from selected marine sites of mixed-function oxidases and related enzymes. Physiol Rev 60:1107-1155

Mziray, P., \& Kimirei, I. A. (2016). Bioaccumulation of heavy metals in marine fishes (Siganus sutor, Lethrinus harak, and Rastrelliger kanagurta) from Dar es Salaam Tanzania. Regional Studies in Marine Science, 7, 72-80.

Naidoo, K., Chuturgoon, A., Cliff, G., Singh, S., Ellis, M., Otway, N., \& Gregory, M. (2017). Possible maternal offloading of metals in the plasma, uterine and capsule fluid of pregnant ragged-tooth sharks (Carcharias taurus) on the east coast of South Africa. Environmental Science and Pollution Research, 24(20), 16798-16805.

Narges, A. B., Ahmad, S., Mohammadsedigh, M., Hossein, Z., Negin, S., \& Zohreh, A. B. (2012). Non-essential metals ( $C d \& \mathrm{~Pb}$ ) accumulation and elimination in liver tissue of juvenile milkfish, after sublethal exposure. 
Nauen, C. E. (1983). Compilation of legal limits for hazardous substances in fish and fishery products. FAO Fisheries Circular - C764. Rome. 762, 102-105.

Nayak, A. S., Lage, C. R., \& Kim, C. H. (2007). Effects of low concentrations of arsenic on the innate immune system of the zebrafish (Danio rerio). Toxicological Sciences, 98(1), 118-124.

Nenadic, A. (1998). The health of yellowbelly flounder (Rhombosolea leporina) from the Waitemata Harbour (Doctoral dissertation, researchspace@ Auckland).

Nieboer, E., \& Richardson, D. H. (1980). The replacement of the nondescript term 'heavy metals' by a biologically and chemically significant classification of metal ions. Environmental Pollution Series B, Chemical and Physical, 1(1), 3-26.

Nriagu, J. (2007). Zinc toxicity in humans. School of Public Health, University of Michigan.

Nussey, H. H. (2000). Bioaccumulation of chromium, manganese, nickel and lead in the tissues of the moggel, Labeo umbratus (Cyprinidae), from Witbank Dam, Mpumalanga. Water Sa, 26(2), 269-284.

Odžak, N., \& Zvonaric, T. (1995). Cadmium and lead uptake from food by the fish Dicentrarchus labrax. Water Science and Technology, 32(9-10), 49-55.

Oehlenschläger, J. (1997). Seafood from producer to consumer: marine fish-a source for essential elements. In: Lutten JB, Borresen T, Oehlenschläger J (eds) Elsevier, Amsterdam, 38,587-607.

Oliver, MD., and Conwell, C. (2014). Te Awarua-o-Porirua Harbour subtidal sediment survey: Results from the 2010 survey. Greater Wellington Regional Council, Publication No. GW/ESCI-T-14/110, Wellington.

Oliver, MD., \& Milne, JR. (2016). Te Awarua-o-Porirua Harbour and Catchment Programme: Summary of scientific monitoring and research undertaken in fulfilment of the Porirua Harbour and Catchment Strategy and Action Plan, 2011- 2015. Greater Wellington Regional Council, Publication No. GW/ESCI-T-16/21, Wellington.

Oliver, MD. (2016). Coastal Water Quality and Ecology Monitoring programme: Annual data report 2015/16. Greater Wellington Regional Council, Publication No. GW/ESCI-T 16/83, Wellington.

Oliver, MD. (2014). Wellington Harbour subtidal sediment quality monitoring: Results from the 2011 survey. Greater Wellington Regional Council, Publication No. GW/ESCI-T $14 / 2$, Wellington.

Ololade, I. A., Lajide, L., Olumekun, V. O., Ololade, O. O., \& Ejelonu, B. C. (2011). Influence of diffuse and chronic metal pollution in water and sediments on edible seafoods 
within Ondo oil-polluted coastal region, Nigeria. Journal of Environmental Science and Health, Part A, 46(8), 898-908.

Omar, W. A., Saleh, Y. S., \& Marie, M. A. S. (2014). Integrating multiple fish biomarkers and risk assessment as indicators of metal pollution along the Red Sea coast of Hodeida, Yemen Republic. Ecotoxicology and environmental safety, 110, 221-231.

Pascoe, D., Evans, S. A., \& Woodworth, J. (1986). Heavy metal toxicity to fish and the influence of water hardness. Archives of Environmental Contamination and Barbara Toxicology, 15(5), 481-487.

Pauly, D., \& Zeller, D. (2016). Catch reconstructions reveal that global marine fisheries catches are higher than reported and declining. Nature communications, 7,102-144.

Pelgrom, S. M. G. J., Lamers, L. P. M., Lock, R. A. C., Balm, P. H. M., \& Wendelaar, B. (1995). Interactions between copper and cadmium modify metal organ distribution in mature tilapia, Oreochromis mossambicus. Environmental Pollution, 90,415-423.

Pelletier, E. (1986). Mercury-selenium interactions in aquatic organisms: a review. Marine Environmental Research, 18(2), 111-132.

Peng, H., Zhang, K., Wan, Y., Hu, J. (2012). Tissue distribution, maternal transfer, and age related accumulation of dechloranes in Chinese sturgeon. Environmental Science Technology, 46, 9907-9913.

Peterson, S. A., Ralston, N. V., Whanger, P. D., Oldfield, J. E., \& Mosher, W. D. (2009). Selenium and mercury interactions with emphasis on fish tissue. Environmental Bioindicators, 4(4), 318-334.

Pethybridge, H., Cossa, D., \& Butler, E. C. (2010). Mercury in 16 demersal sharks from southeast Australia: biotic and abiotic sources of variation and consumer health implications. Marine Environmental Research, 69(1), 18-26.

Phillips, D. J. H. (1980). Quantitative aquatic biological indicators. Pollution monitoring series. London: Applied Science Publishers.

Pickhardt, P. C., Stepanova, M., \& Fisher, N. S. (2006). Contrasting uptake routes and tissue distributions of inorganic and methylmercury in mosquitofish (Gambusia affinis) and redear sunfish (Lepomis microlophus). Environmental Toxicology and Chemistry, 25(8), 2132-2142.

Pickard, C. B. (2007). Late Mesolithic coastal fishing practices. On the Road: Studies in Honour of Lars Larsson, $176-183$.

Pierre Cresson, M. T.T., Manuel, R., Charles-André, T. (2017). Underestimation of chemical contamination in marine fish muscle tissue can be reduced by considering variable wet:dry weight ratios. Marine Pollution Bulletin, 123(1-2), 279-285. 
Pieterse, G. M. (2004). Histopathological changes in the testis of Oreochromis mossambicus (Cichlidae) as a biomarker of heavy metal pollution.

Plaskett, D., \& Potter, I. C. (1979). Heavy metal concentrations in the muscle tissue of 12 species of teleost from Cockburn Sound, Western Australia. Marine and Freshwater Research, 30(5), 607-616.

Pouil, S., Teyssié, J. L., Rouleau, C., Fowler, S. W., Metian, M., Bustamante, P., \& Pourang, N., A. Nikouyan, and J. H. Dennis. (2005). "Trace element concentrations in fish, surficial sediments and water from northern part of the Persian Gulf." Environmental monitoring and assessment, 109,(3), 293-316.

Pourang, N., Nikouyan, A., \& Dennis, J. H. (2005). Trace element concentrations in fish, surficial sediments and water from northern part of the Persian Gulf. Environmental Monitoring and Assessment, 109, 293-316.

R-Core-Team. (2016). A Language and Environment for Statistical Computing. R Foundation R. 500:4-6. For Statistical Computing,. Retrieved from https://R-project.org/.

Radford, C. A., Sim-Smith, C. J., \& Jeffs, A. G. (2012). Can larval snapper, Pagrus auratus, smell their new home?. Marine and Freshwater Research, 63(10), 898-904.

Rahman, M. S., Molla, A. H., Saha, N., \& Rahman, A. (2012). Study on heavy metals levels and its risk assessment in some edible fishes from Bangshi River, Savar, Dhaka, Bangladesh. Food Chemistry, 103, 40-56.

Ramsdorf, W. A., Vicari, T., de Almeida, M. I., Artoni, R. F., \& Cestari, M. M. (2012). Handling of Astyanax sp. For biomonitoring in Cangüiri Farm within a fountainhead (Iraí River Environment Preservation Area) through the use of genetic biomarkers. Environmental monitoring and assessment, 184(10), 5841-5849.

Reichert, M. J. (1998). Etropus crossotus, an annual flatfish species; age and growth of the fringed flounder in South Carolina. Journal of Sea Research, 40(3-4), 323-332.

Reichert, M. J., Dean, J. M., Feller, R. J., \& Grego, J. M. (2000). Somatic growth and otolith growth in juveniles of a small subtropical flatfish, the fringed flounder, Etropus crossotus. Journal of Experimental Marine Biology and Ecology, 254(2), 169-188.

Rejomon, G. (2005). Biogeochemistry of trace metals in the Indian Exclusive Ecnomic Zone (EEZ) of the Arabian Sea and Bay of Bengal (Doctoral dissertation, Doctoral Thesis. India: Cochin University of Science and Technology).

Rejomon, G., Nair, M., \& Joseph, T. (2010). Trace metal dynamics in fishes from the southwest coast of India. Environmental Monitoring and Assessment, 167(1-4), 243 255. 
Ribeyre, F., Amiardtriquet, C., Boudou, A., \& Amiard, J. C. (1995). Experimental-Study of Interactions between Five Trace Elements- $\mathrm{Cu}, \mathrm{Ag}, \mathrm{Se}, \mathrm{Zn}$, and $\mathrm{Hg}$-Toward Their= Bioaccumulation by Fish (Brachydanio rerio) from the Direct Route. Ecotoxicology and Environmental Safety, 32(1), 1-11.

Robertson, B. P., Gardner, J. P., \& Savage, C. (2015). Macrobenthic-mud relations strengthen the foundation for benthic index development: a case study from shallow, temperate New Zealand estuaries. Ecological Indicators, 58, 161-174.

Roper, D. S. (1986). Occurrence and recruitment of fish larvae in a northern New Zealand estuary. Estuarine, Coastal and Shelf Science, 22(6), 705-717.

Ross, P. S., Ellis, G. M., Ikonomou, M. G., Barrett-Lennard, L. G., \& Addison, R. F. (2000). High PCB concentrations in free-ranging Pacific killer whales, Orcinus orca: effects of age, sex and dietary preference. Marine Pollution Bulletin, 40(6), 504-515.

Sadiq, M., Saeed, T., Fowler, SW. (2002). Seafood contamination. In: Khan NY, Munawar, Price ARG (eds) The gulf ecosystem: health and sustainability. Bakhuys, Leiden, 327-351,

Saha, N., Mollah, M. Z. I., Alam, M. F., \& Rahman, M. S. (2016). Seasonal investigation of heavy metals in marine fishes captured from the Bay of Bengal and the implications for human health risk assessment. Food control, 70, 110-118.

Sanchez, W., Palluel, O., Meunier, L., Coquery, M., Porcher, J. M., \& Ait-Aissa, S. (2005). Copper-induced oxidative stress in three-spined stickleback: relationship with hepatic metal levels. Environmental toxicology and pharmacology, 19(1), 177-183.

Sandoval-Herrera, N. I., Vargas-Soto, J. S., Espinoza, M., Clarke, T. M., Fisk, A. T., \& Wehrtmann, I. S. (2016). Mercury levels in muscle tissue of four common elasmobranch species from the Pacific coast of Costa Rica, Central America. Regional Studies in Marine Science, 3, 254-261.

Sfakianakis, D. G., Renieri, E., Kentouri, M., \& Tsatsakis, A. M. (2015). Effect of heavy metals on fish larvae deformities: a review. Environmental research, 137, 246-255.

Shao, C., Bao, B., Xie, Z., Chen, X., Li, B., Jia, X., \& Hamre, K. (2017). The genome and transcriptome of Japanese flounder provide insights into flatfish asymmetry. Nature genetics, 49(1), 119.

Sheaves, M., Baker, R., Nagelkerken, I., \& Connolly, R. M. (2015). True value of estuarine and coastal nurseries for fish: incorporating complexity and dynamics. Estuaries and Coasts, 38(2), 401-414.

Smale, M. J., \& Compagno, L. J. V. (1997). Life history and diet of two southern African smooth-hound sharks, Mustelus mustelus (Linnaeus, 1758) and Mustelus palumbes 
Smith, 1957 (Pisces: Triakidae). South African Journal of Marine Science, 18(1), 229 248.

Sprague, J. B. (1987). Effects of cadmium on freshwater fish. Advances in Environmental Science and Technology[ADV. ENVIRON. SCI. TECHNOL.]. 1987.

Spry, D. J., \& Wiener, J. G. (1991). Metal bioavailability and toxicity to fish in low-alkalinity lakes: a critical review. Environmental Pollution, 71(2-4), 243-304.

Stagg, R. M., and Shuttleworth, T. J. (1982). The accumulation of copper in Platichthys flesus L. And its effects on plasma electrolyte concentrations. Journal of Fish Biology, 20, 491-500.

Stankevičiūtė, M., Sauliutė, G., Svecevičius, G., Kazlauskienė, N., \& Baršienė, J. (2017). Genotoxicity and cytotoxicity response to environmentally relevant complex metal mixture ( $\mathrm{Zn}, \mathrm{Cu}, \mathrm{Ni}, \mathrm{Cr}, \mathrm{Pb}, \mathrm{Cd}$ ) accumulated in Atlantic salmon (Salmo salar). Part I: importance of exposure time and tissue dependence. Ecotoxicology, 26(8), 1051 1064.

Steffens, W. (2006). Freshwater fish-wholesome foodstuffs. Bulgarian Journal of Agricultural Science, 12(2), 320.

Stevens, L. (2017). Porirua Harbour: Intertidal sediment monitoring 2016/17. Report prepared for Greater Wellington Regional Council by Wriggle Coastal Management, Nelson.

Stevens, D. S., M.H.; Grimes, P.; Devine, J.; Sutton, C., \& macgibbon, D. Ó. M., C. (2010). Age, growth, and maturity of four New Zealand rattail species Retrieved from Wellington.

Stevens, D. W., Francis, M. P., Shearer, P. C., mcphee, R. P., Hickman, R. W., \& Tait, M. J. (2005). Age and growth of two endemic flatfish (Colistium guntheri and C. Nudipinnis) in central New Zealand waters. Marine and Freshwater Research, 56(2), 143-151.

Stoffers, P., Glasby, G. P., Wilson, C. J., Davis, K. R., \& Walter, P. (1986). Heavy metal pollution in Wellington Harbour. New Zealand journal of marine and freshwater research, 20(3), 495-512.

Storelli, M. M., Giacominelli-stuffler, R., Storelli, A., \& Marcotrigiano, G. O. (2005). Accumulation of mercury, cadmium, lead and arsenic in swordfish and bluefin tuna from the Mediterranean Sea: a comparative study. Marine pollution bulletin, 50, 1004-1007.

Storelli, M. M., Giacominelli-Stuffler, R., \& Marcotrigiano, G. O. (2002). Mercury accumulation and speciation in muscle tissue of different species of sharks from 
Mediterranean Sea, Italy. Bulletin of Environmental Contamination and Toxicology, 68(2), 201-210.

Sudsandee, S., Tantrakarnapa, K., Tharnpoophasiam, P., Limpanont, Y., Mingkhwan, R., \& Worakhunpiset, S. (2017). Evaluating health risks posed by heavy metals to humans consuming blood cockles (Anadara granosa) from the Upper Gulf of Thailand. Environmental Science and Pollution Research, 24(17), 14605-14615.

Tacon, A. G., \& Metian, M. (2015). Feed matters: satisfying the feed demand of aquaculture. Reviews in Fisheries Science \& Aquaculture, 23(1), 1-10.

Team, R. (2015). Intergrated Development for rstudio. Retrieved from http://www.rstudio.com

The Commission of the European Communities, Commission regulation (EC) No 1881/2006. Off J Eur Union L 364:5-24 (2006)

Thompson, DR. (1990). Metal levels in marine vertebrates. In: Furness RW, Rainbow PS (ed) Heavy metals in the marine environment. CRC Press, Boca Raton, Florida, 143-182.

Tomlinson, D. L., Wilson, J. G., Harris, C. R., \& Jeffrey, D. W. (1980). Problems in the assessment of heavy-metal levels in estuaries and the formation of a pollution index. Helgoländer meeresuntersuchungen, 33(1), 566.

Topcuoğlu, S., Güven, K. C., Balkıs N., \& Kırbaşoğlu, C. (2003). Heavy metal monitoring of marine algae from the Turkish Coast of the Black Sea, 1998-2000. Chemosphere, 52, 1683-1688.

Tort, L., \& Torres, P. (1988). The effects of sublethal concentrations of cadmium on haematological parameters in the dogfish, Scyliorhinus canicula. Journal of Fish Biology, 32(2), 277-282.

Trudel, M., \& Rasmussen, J. B. (1997). Modeling the elimination of mercury by fish. Environmental Science \& Technology, 31(6), 1716-1722.

Türkmen, M., Türkmen, A., \& Tepe, Y. (2014). Comparison of metal levels in different tissues of seven ray species from Antalya Bay, Mediterranean Sea. Bulletin of environmental contamination and toxicology, 93(2), 159-164.

Turner, M. A., \& Swick, A. L. (1983). The English-Wabigoon river system: IV. Interaction between mercury and selenium accumulated from waterborne and dietary sources by Northern Pike (Esox lucius). Canadian Journal of Fisheries and Aquatic Sciences, 40(12), 2241-2250.

Urena, R., Peri, S., Del Ramo, J., \& Torreblanca, A. (2007). Metal and metallothionein content in tissues from wild and farmed Anguilla anguilla at commercial size. Environment International, 33, 532-539 
Usero, J., Izquierdo, C., Morillo, J., \& Gracia, I. (2004). Heavy metals in fish (Solea vulgaris, Anguilla anguilla and Liza aurata) from salt marshes on the southern Atlantic coast of Spain. Environment International, 29, 949-956

Uysal, K., Emre, Y., \& Köse, E. (2008). The determination of heavy metal accumulation ratios in muscle, skin and gills of some migratory fish species by inductively coupled plasma-optical emission spectrometry (ICP-OES) in Beymelek Lagoon (Antalya/Turkey). Microchemical journal, 90(1), 67-70.

Uysal, K., Köse, E., Bülbül, M., Dönmez, M., Erdoğan, Y., Koyun, M., \& Özmal, F. (2009). The comparison of heavy metal accumulation ratios of some fish species in Enne Dame Lake (Kütahya/Turkey). Environmental monitoring and assessment, 157(1-4), 355-362.

Van den Steen, E., Jaspers, V.L.B., Covaci, A., Neels, H., Eens, M., \& Pinxten, R. (2009). Maternal transfer of organochlorines and brominated flame retardants Lyons and Lowe 1671 Published by NRC Research Press Can. J. Fish. Aquat. Sci. Downloaded from www.nrcresearchpress.com by 121.74.148.103 on 01/06/19 For personal use only. In blue tits (Cyanistes caeruleus). Environment International, 35(1), 69-75.

Van Hees, K. E., \& Ebert, D. A. (2017). An evaluation of mercury offloading in two Central California elasmobranchs. Science of the Total Environment, 590, 154-162.

Van Leeuwen, P., Vethaak, AD. (1988). Growth of European flounder (Platichthysflesus) and common dab (Limanda limanda) in Dutch coastal waters with reference to healthy and diseased fish. International Council for the Exploration of the SEA C.M./G, 54.

Varol, M., Kaya, G. K., \& Alp, A. (2017). Heavy metal and arsenic concentrations in rainbow trout (Oncorhynchus mykiss) farmed in a dam reservoir on the Firat (Euphrates) River: Risk-based consumption advisories. Science of The Total Environment, 599, 1288-1296.

Verriopoulos, G., Dimas, S. (1988). Combined toxicity of copper, cadmium, zinc, lead nickel, and chrome to the copepod Tisbe holothuriae. Bulletin of Environmental Contaminants and Toxicology, 41, 378-384.

Vethaak, AD., Wester, PW. (1993). Liver histopathology of flounder (Platichthysflesus) in Dutch coastal and estuarine waters, with particular reference to environmental

stress factors. Part 2: Liver histopathology. Disease of Aquatic Organisms, 16(99), 273-286.

Vethaak, A. D., \& Jol, J. G. (1996). Diseases of flounder Platichthys flesus in Dutch coastal and estuarine waters, with particular reference to environmental stress factors. I. Epizootiology of gross lesions. Diseases of Aquatic Organisms, 26(2), 81-97.

Vethaak, A. D., Jol, J. G., Meijboom, A., Eggens, M. L., Rheinallt, T. A., Wester, P. W., \& Baan, R. A. (1996). Skin and liver diseases induced in flounder (Platichthys flesus) 
after long-term exposure to contaminated sediments in large

scale mesocosms. Environmental Health Perspectives, 104(11), 1218.

Vieira, L. R., Gravato, C., Soares, A. M. V. M., Morgado, F., \& Guilhermino, L. (2009). Acute effects of copper and mercury on the estuarine fish Pomatoschistus microps: linking biomarkers to behaviour. Chemosphere, 76(10), 1416-1427.

Vinodhini, R., \& Narayanan, M. (2008). Bioaccumulation of heavy metals in organs of fresh water fish Cyprinus carpio (Common carp). International Journal of Environmental Science \& Technology, 5(2), 15-22.

Walker, T. I. (1976). Effects of species, sex, length and locality on the mercury content of school shark Galeorhinus australis (Macleay) and gummy shark Mustelus antarcticus Guenther from south-eastern Australian waters. Marine and Freshwater Research, 27(4), 603-616

Wang, W. X., Onsanit, S., \& Dang, F. (2012). Dietary bioavailability of cadmium, inorganic mercury, and zinc to a marine fish: effects of food composition and type. Aquaculture, 356, 98-104.

Weis, J.S. (1980). Effect of zinc on regeneration in the fiddler crab Uca pugilator and its interactions with methylmercury and cadmium. Marine Environmental Research, 3, 249-255.

Wepener, V., Van Vuren, J. H. J., \& Du Preez, H. H. (2001). Uptake and distribution of a copper, iron and zinc mixture in gill, liver and plasma of a freshwater teleost, Tilapia sparrmanii. Water sa, 27(1), 99-108.

Wicklund, A., Runn, P., Norrgren, L. (1988). Cadmium and zinc interactions in fish : Effects of zinc on the uptake, organ, distribution, and elimination of $109 \mathrm{Cd}$ in the zebrafish, Brachydanio rerio. Archives of Environmental Contamination and Toxicology, 17, 345-354.

Widianarko, B., Van Gestel, C. A. M., Verweij, R. A., \& Van Straalen, N. M. (2000). Associations between trace metals in sediment, water, and guppy, Poecilia reticulata (Peters), from urban streams of Semarang, Indonesia. Ecotoxicology and Environmental Safety, 46(1), 101-107.

Witeska, M., Jezierska, B., \& Chaber, J. (1995). The influence of cadmium on common carp embryos and larvae. Aquaculture, 129(1), 129-132.

Wong, C. K., Wong, P. P. K., \& Chu, L. M. (2001). Heavy metal concentrations in marine fishes collected from fish culture sites in Hong Kong. Archives of Environmental Contamination and Toxicology, 40(1), 60-69. 
Xu, Y., \& Wang, W. X. (2002). Exposure and potential food chain transfer factor of Cd, Se and $\mathrm{Zn}$ in marine fish Lutjanus argentimaculatus. Marine Ecology Progress Series, 238, 173-186.

Yang, X., \& Baumann, P. C. (2006). Biliary PAH metabolites and the hepatosomatic index of brown bullheads from Lake Erie tributaries Ecological Indicators, 6(3), 567-574.

Yi, Y. J., \& Zhang, S. H. (2012). Heavy metal (Cd, Cr, Cu, Hg, Pb, Zn) concentrations in seven fish species in relation to fish size and location along the Yangtze River. Environmental Science and Pollution Research, 19(9), 3989-3996.

Yilmaz, A. B. (2003). Levels of heavy metals ( $\mathrm{Fe}, \mathrm{Cu}, \mathrm{Ni}, \mathrm{Cr}, \mathrm{Pb}$, and $\mathrm{Zn}$ ) in tissue of Mugil cephalus and Trachurus mediterraneus from Iskenderun Bay, Turkey. Environmental Research, 92(3), 277-281.

Yilmaz, F. (2009). The comparison of heavy metal concentrations ( $\mathrm{Cd}, \mathrm{Cu}, \mathrm{Mn}, \mathrm{Pb}$, and $\mathrm{Zn}$ ) in tissues of three economically important fish (Anguilla anguilla, Mugil cephalus and Oreochromis niloticus) inhabiting Koycegiz Lake-Mugla (Turkey). Turkish Journal of Science \& Technology, 4(1).

Yilmaz, F. (2009). The comparison of heavy metal concentrations ( $\mathrm{Cd}, \mathrm{Cu}, \mathrm{Mn}, \mathrm{Pb}$, and $\mathrm{Zn}$ ) in tissues of three economically important fish (Anguilla anguilla, Mugil cephalus and Oreochromis niloticus) inhabiting Koycegiz Lake-Mugla (Turkey). Turkish Journal of Science \& Technology, 4(1).

Yılmaz, A. B., Sangün, M. K., Yağlıoğlu, D., \& Turan, C. (2010). Metals (major, essential to non-essential) composition of the different tissues of three demersal fish species from Iskenderun Bay, Turkey. Food chemistry, 123(2), 410-415.

Yılmaz, F., Özdemir, N., Demirak, A., \& Tuna, A. L. (2007). Heavy metal levels in two fish species Leuciscus cephalus and Lepomis gibbosus. Food Chemistry, 100(2), 830-835.

Zaera, D., \& Johnsen, E. (2011). Foetal deformities in a smooth-hound shark, Mustelus mustelus, from an oil exploited area in Angola/Malformations chez un foetus de requin emissole, Mustelus mustelus, capture dans une zone d'exploitation de petrole en Angola. Cybium, International Journal of Ichthyology, 35(3), 231-237.

Zaki ${ }^{1}$, M. S., Sharaf, N. E., \& Osfor, M. H. (2010). Effect of vanadium toxicity in Clarias lazera. Journal of American Science, 6(12).

Zauke, G. P., Savinov, V. M., Ritterhoff, J., \& Savinova, T. (1999). Heavy metals in fish from the Barents Sea (summer 1994). Science of the Total Environment, 227(2), 161-173.

Zhao, S., Feng, C., Quan, W., Chen, X., Niu, J., \& Shen, Z. (2012). Role of living environmentsin the accumulation characteristics of heavy metals in fishes and crabs in the Yangtze River Estuary, China. Marine pollution bulletin, 64(6), 1163-1171. 


\section{Appendices}

\section{Appendix A}

Table 1: Table showing all species collected from Porirua Harbour in 2018 for heavy metal analysis.

\begin{tabular}{|c|c|c|c|c|c|c|}
\hline species & Species & Common Name & Maori Name Sex & Weight (g) & Location captured & Date captured \\
\hline SS1 & Peltorhamphus latus & speckled sole & & 13.5 & Ngati Toa Domain & $4 / 05 / 18$ \\
\hline SS2 & Peltorhamphus latus & speckled sole & & 10 & Ngati Toa Domain & $4 / 05 / 18$ \\
\hline SS3 & Peltorhamphus latus & speckled sole & & 13.5 & Ngati Toa Domain & $4 / 05 / 18$ \\
\hline SS4 & Peltorhamphus latus & speckled sole & & 7.9 & Ngati Toa Domain & $4 / 05 / 18$ \\
\hline SS5 & Peltorhamphus latus & speckled sole & & 13.6 & Ngati Toa Domain & $4 / 05 / 18$ \\
\hline SS6 & Peltorhamphus latus & speckled sole & & 10 & Ngati Toa Domain & $4 / 05 / 18$ \\
\hline SS7 & Peltorhamphus latus & speckled sole & & 12 & Ngati Toa Domain & $4 / 05 / 18$ \\
\hline SS8 & Peltorhamphus latus & speckled sole & & 8.5 & Ngati Toa Domain & $4 / 05 / 18$ \\
\hline SS9 & Peltorhamphus latus & speckled sole & & 14.5 & Ngati Toa Domain & $4 / 05 / 18$ \\
\hline SS10 & Peltorhamphus latus & speckled sole & & 11.4 & Ngati Toa Domain & $4 / 05 / 18$ \\
\hline SF3 & Rhombosolea plebeia & sand flounder & & 24 & Motukarakara Pnt Nth & $17 / 05 / 18$ \\
\hline SF4 & Rhombosolea plebeia & sand flounder & & 27 & Motukarakara Pnt Sth & $1 / 06 / 18$ \\
\hline SF5 & Rhombosolea plebeia & sand flounder & & 37 & Motukarakara Pnt Nth & $31 / 05 / 18$ \\
\hline SF6 & Rhombosolea plebeia & sand flounder & & 35 & James Cook Drive & $15 / 06 / 18$ \\
\hline SF11 & Rhombosolea plebeia & sand flounder & & 42 & Motukarakara Pnt Nth & $17 / 05 / 18$ \\
\hline SF12 & Rhombosolea plebeia & sand flounder & & 13 & Motukarakara Pnt Nth & $17 / 05 / 18$ \\
\hline SF13 & Rhombosolea plebeia & sand flounder & & 6.9 & $\begin{array}{l}\text { Ngati Toa Domain } \\
\text { (opposite) }\end{array}$ & $4 / 05 / 18$ \\
\hline YB2 & Rhombosolea leporina & $\begin{array}{l}\text { yellow belly } \\
\text { flounder }\end{array}$ & & 38 & Motukarakara Pnt Nth & $29 / 06 / 18$ \\
\hline
\end{tabular}




\begin{tabular}{|c|c|c|c|c|c|c|c|}
\hline YB3 & Rhombosolea leporina & $\begin{array}{l}\text { yellow belly } \\
\text { flounder }\end{array}$ & & 39 & & Motukarakara Pnt Nth & $17 / 05 / 18$ \\
\hline YB4 & Rhombosolea leporina & $\begin{array}{l}\text { yellow belly } \\
\text { flounder }\end{array}$ & & 34 & & Motukarakara Pnt Nth & $17 / 05 / 18$ \\
\hline YB5 & Rhombosolea leporina & $\begin{array}{l}\text { yellow belly } \\
\text { flounder }\end{array}$ & & 45 & & Motukarakara Pnt Nth & $31 / 05 / 18$ \\
\hline YB6 & Rhombosolea leporina & $\begin{array}{l}\text { yellow belly } \\
\text { flounder }\end{array}$ & & 42 & & Motukarakara Pnt Nth & $31 / 05 / 18$ \\
\hline YB7 & Rhombosolea leporina & $\begin{array}{l}\text { yellow belly } \\
\text { flounder }\end{array}$ & & 37 & & Motukarakara Pnt Nth & $31 / 05 / 18$ \\
\hline YB8 & Rhombosolea leporina & $\begin{array}{l}\text { yellow belly } \\
\text { flounder }\end{array}$ & & 47 & & Motukarakara Pnt Nth & $31 / 05 / 18$ \\
\hline YB9 & Rhombosolea leporina & $\begin{array}{l}\text { yellow belly } \\
\text { flounder }\end{array}$ & & 47 & & Motukarakara Pnt Sth & $1 / 06 / 18$ \\
\hline YB10 & Rhombosolea leporina & $\begin{array}{l}\text { yellow belly } \\
\text { flounder }\end{array}$ & & 33 & & Motukarakara Pnt Sth & $15 / 06 / 18$ \\
\hline YB11 & Rhombosolea leporina & $\begin{array}{l}\text { yellow belly } \\
\text { flounder }\end{array}$ & & 27 & & Motukarakara Pnt Sth & $15 / 06 / 18$ \\
\hline RS6 & Mustelus lenticulatus & Rig Shark & $\begin{array}{l}\text { Pioke, Makō, F } \\
\text { Mangō }\end{array}$ & 92 & 3.5 & Wi Neera Dr & $4 / 04 / 18$ \\
\hline RS7 & Mustelus lenticulatus & Rig Shark & $\mathrm{M}$ & 82 & 2.28 & Wi Neera Dr & $4 / 04 / 18$ \\
\hline RS8 & Mustelus lenticulatus & Rig Shark & $\mathrm{F}$ & 97 & 4 & Wi Neera Dr & $4 / 04 / 18$ \\
\hline RS9 & Mustelus lenticulatus & Rig Shark & $\mathrm{F}$ & 96 & 4 & Wi Neera Dr & $4 / 04 / 18$ \\
\hline RS10 & Mustelus lenticulatus & Rig Shark & $\mathrm{M}$ & 76 & 2.6 & Wi Neera Dr & $4 / 04 / 18$ \\
\hline RS11 & Mustelus lenticulatus & Rig Shark & $\mathrm{F}$ & 91 & 3.3 & Wi Neera Dr & $4 / 04 / 18$ \\
\hline RS12 & Mustelus lenticulatus & Rig Shark & $\mathrm{F}$ & 94 & 3.4 & Wi Neera Dr & $4 / 04 / 18$ \\
\hline RS13 & Mustelus lenticulatus & Rig Shark & $\mathrm{F}$ & 97 & 3.6 & Wi Neera Dr & $4 / 04 / 18$ \\
\hline RS14 & Mustelus lenticulatus & Rig Shark & $\mathrm{F}$ & 93 & 3.3 & Wi Neera Dr & $4 / 04 / 18$ \\
\hline RS15 & Mustelus lenticulatus & Rig Shark & & 13 & 0.014 & Wi Neera Dr & $4 / 04 / 18$ \\
\hline RS22 & Mustelus lenticulatus & Rig Shark & $\mathrm{F}$ & 107 & 5.5 & Titahi Bay Rd & $24 / 04 / 18$ \\
\hline RS23 & Mustelus lenticulatus & Rig Shark & $\mathrm{F}$ & 96 & 4.9 & Titahi Bay Rd & $24 / 04 / 18$ \\
\hline RS24 & Mustelus lenticulatus & Rig Shark & $\mathrm{F}$ & 91 & 3 & Titahi Bay Rd & $24 / 04 / 18$ \\
\hline
\end{tabular}




\begin{tabular}{|c|c|c|c|c|c|c|c|c|}
\hline RS25 & Mustelus lenticulatus & Rig Shark & & $\mathrm{F}$ & 84 & 2.3 & Titahi Bay Rd & $26 / 04 / 18$ \\
\hline RS26 & Mustelus lenticulatus & Rig Shark & & $\mathrm{F}$ & 86 & 3 & Titahi Bay Rd & $26 / 04 / 18$ \\
\hline RS27 & Mustelus lenticulatus & Rig Shark & & $\mathrm{M}$ & & & Titahi Bay Rd & \\
\hline RS33 & Mustelus lenticulatus & Rig Shark & & $\mathrm{F}$ & 97 & & Titahi Bay Rd & $2 / 05 / 18$ \\
\hline RS34 & Mustelus lenticulatus & Rig Shark & & $\mathrm{F}$ & 88 & & Titahi Bay Rd & $2 / 05 / 18$ \\
\hline RS35 & Mustelus lenticulatus & Rig Shark & & $\mathrm{F}$ & 89 & 3.2 & Titahi Bay Rd & $2 / 05 / 18$ \\
\hline RS37 & Mustelus lenticulatus & Rig Shark & & $\mathrm{F}$ & 96.5 & 4 & Wi Neera Dr & $9 / 05 / 18$ \\
\hline RS39 & Mustelus lenticulatus & Rig Shark & & $\mathrm{F}$ & 101 & 4 & Motukarakara Pnt Nth & $31 / 05 / 18$ \\
\hline ER3 & Myliobatis tenuicaudatus & eagle ray & Whai keo & $\mathrm{F}$ & 58 & & Onepoto Rd & $12 / 04 / 18$ \\
\hline ER4 & Myliobatis tenuicaudatus & eagle ray & & $\mathrm{F}$ & 88 & & Titahi Bay Rd & $14 / 04 / 18$ \\
\hline ER5 & Myliobatis tenuicaudatus & eagle ray & & $\mathrm{F}$ & 64 & & Titahi Bay Rd & $16 / 04 / 18$ \\
\hline ER6 & Myliobatis tenuicaudatus & eagle ray & & $\mathrm{F}$ & 91 & & Titahi Bay Rd & $24 / 04 / 18$ \\
\hline STR1 & Bathytoshia brevicaudata & $\begin{array}{l}\text { short tailed } \\
\text { stingray }\end{array}$ & Whai & $\mathrm{M}$ & 80 & & Motukarakara Pnt Nth & $17 / 05 / 18$ \\
\hline
\end{tabular}




\section{Appendix B}

\section{Mark-recapture study}

Type TBA anchor tags (Figure 1), purchased from Hallprint were used in the mark/recapture component in this study.

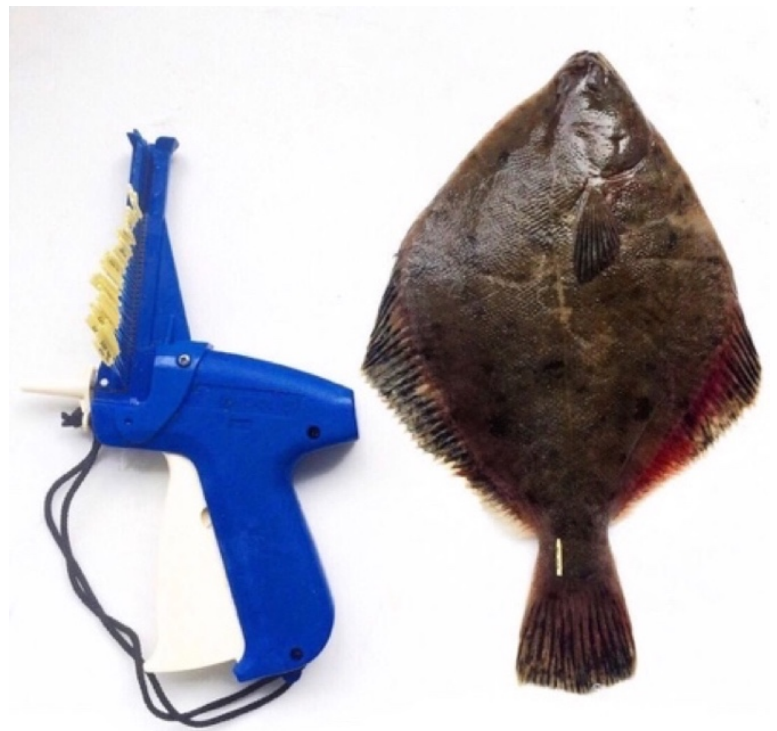

Figure 1: Photograph showing the Hallprint type TBA anchor tagging gun and a tag in the left tail fin of a female juvenile sand flounder, caught in Pauatahanui inlet in 2018.

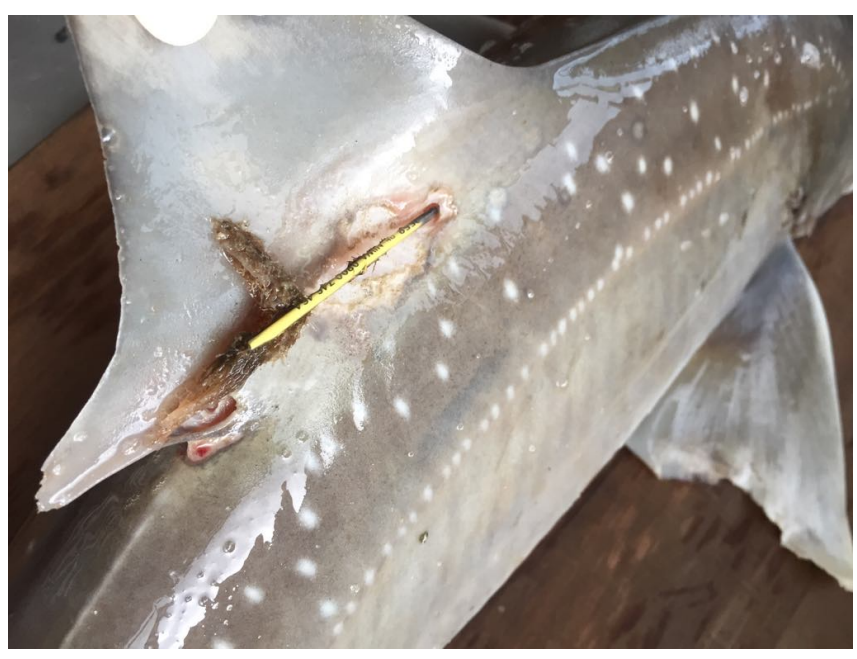

Figure 2: Photograph showing a NIWA anchor tag on one of my captured rig shark, captured in Onepoto in 2018. 
A male rig shark was collected from Titahi Bay Road in Onepoto that was tagged 2 years prior during a NIWA study (NIWA tag ID\#3558). The anchor tag shows a deep laceration and algae (figure 2), which indicates this type of tag might be more problematic to rig shark than previously thought (i.e by providing drag and making individual more susceptible to infection through open wound). Consideration should be put into alternative tagging methods in the future. 
Table 2: Table showing $n=69$ tagged fishes in Porirua Harbour during a 4-month mark-recapture study in 2018

\begin{tabular}{|c|c|c|c|c|c|c|c|c|c|c|}
\hline Species ID & species & $\begin{array}{l}\text { Common } \\
\text { name }\end{array}$ & Maori Name & sex & tag number & $\mathrm{TL}(\mathrm{CM})$ & $\begin{array}{l}\text { Disc } \\
\text { Length } \\
(\mathrm{Cm})\end{array}$ & $\begin{array}{l}\text { Tail Length } \\
(\mathrm{Cm})\end{array}$ & Location & Date \\
\hline RS1 & Mustelus lenticulatus & Rig shark & $\begin{array}{l}\text { Pioke, Makō, } \\
\text { Mangō }\end{array}$ & $\mathrm{M}$ & 299 & 71 & & & Titahi Bay Rd & $20 / 03 / 18$ \\
\hline RS3 & Mustelus lenticulatus & Rig shark & & $M$ & 304 & 75 & & & Onepoto Rd & $28 / 03 / 18$ \\
\hline RS5 & Mustelus lenticulatus & Rig shark & & $\mathrm{F}$ & 297 & 91 & & & Titahi Bay Rd & $20 / 03 / 18$ \\
\hline RS16 & Mustelus lenticulatus & Rig shark & & $\mathrm{F}$ & 306 & 86 & & & Wi Neera Dr & $4 / 04 / 18$ \\
\hline RS17 & Mustelus lenticulatus & Rig shark & & $\mathrm{F}$ & 307 & 83 & & & Wi Neera Dr & $4 / 04 / 18$ \\
\hline RS18 & Mustelus lenticulatus & Rig shark & & $\mathrm{M}$ & 308 & 65 & & & Wi Neera Dr & $4 / 04 / 18$ \\
\hline RS19 & Mustelus lenticulatus & Rig shark & & $\mathrm{F}$ & 309 & 91 & & & Wi Neera Dr & $4 / 04 / 18$ \\
\hline RS21 & Mustelus lenticulatus & Rig shark & & $\mathrm{F}$ & 311 & 90 & & & Wi Neera Dr & $4 / 04 / 18$ \\
\hline RS28 & Mustelus lenticulatus & Rig shark & & $\mathrm{F}$ & 316 & 87 & & & Wi Neera Dr & $26 / 04 / 18$ \\
\hline RS29 & Mustelus lenticulatus & Rig shark & & $\mathrm{F}$ & 317 & 90 & & & Wi Neera Dr & $27 / 04 / 18$ \\
\hline RS30 & Mustelus lenticulatus & Rig shark & & $\mathrm{M}$ & 319 & 76 & & & Wi Neera Dr & $28 / 04 / 18$ \\
\hline RS31 & Mustelus lenticulatus & Rig shark & & $\mathrm{M}$ & 320 & 78 & & & Wi Neera Dr & $28 / 04 / 18$ \\
\hline RS32 & Mustelus lenticulatus & Rig shark & & $\mathrm{F}$ & 321 & 88 & & & Wi Neera Dr & $28 / 04 / 18$ \\
\hline RS36 & Mustelus lenticulatus & Rig shark & & $\mathrm{F}$ & 324 & 100 & & & Titahi Bay Rd & $2 / 05 / 18$ \\
\hline RS38 & Mustelus lenticulatus & Rig shark & & $\mathrm{F}$ & 325 & 93 & & & Titahi Bay Rd & $9 / 05 / 18$ \\
\hline
\end{tabular}




\begin{tabular}{|c|c|c|c|c|c|c|c|c|c|c|}
\hline RS40 & Mustelus lenticulatus & Rig shark & & $M$ & 341 & 93 & & & Motukarakara Pt Nth & $15 / 06 / 18$ \\
\hline RS41 & Mustelus lenticulatus & Rig shark & & $\mathrm{F}$ & 380 & 92 & & & Titahi Bay Rd & $12 / 08 / 18$ \\
\hline RS42 & Mustelus lenticulatus & Rig shark & & $\mathrm{F}$ & 323 & 98 & & & Titahi Bay Rd & $2 / 05 / 18$ \\
\hline ER1 & $\begin{array}{l}\text { Myliobatis } \\
\text { tenuicaudatus }\end{array}$ & Eagle ray & Whai keo & $\mathrm{F}$ & 300 & 53 & 62 & 0 & Titahi Bay Rd & $20 / 03 / 18$ \\
\hline ER2 & $\begin{array}{l}\text { Myliobatis } \\
\text { tenuicaudatus }\end{array}$ & Eagle ray & & $\mathrm{F}$ & 301 & 47 & 75 & 59 & Onepoto Rd & $28 / 03 / 18$ \\
\hline ER3 & $\begin{array}{l}\text { Myliobatis } \\
\text { tenuicaudatus }\end{array}$ & Eagle ray & & $\mathrm{F}$ & 302 & 58 & 84 & 72 & Onepoto Rd & $12 / 04 / 18$ \\
\hline ER4 & $\begin{array}{l}\text { Myliobatis } \\
\text { tenuicaudatus }\end{array}$ & Eagle ray & & $\mathrm{F}$ & 305 & 88 & 96 & 64 & Titahi Bay Rd & $14 / 04 / 18$ \\
\hline ER5 & $\begin{array}{l}\text { Myliobatis } \\
\text { tenuicaudatus }\end{array}$ & Eagle ray & & $\mathrm{F}$ & 313 & 64 & 93 & 83 & Titahi Bay Rd & $16 / 04 / 18$ \\
\hline ER6 & $\begin{array}{l}\text { Myliobatis } \\
\text { tenuicaudatus }\end{array}$ & Eagle ray & & $\mathrm{F}$ & 315 & 91 & 108 & 76 & Titahi bay Rd & $24 / 04 / 18$ \\
\hline M1 & Aldrichetta forsteri & $\begin{array}{l}\text { Yellow eyed } \\
\text { mullet }\end{array}$ & Aua, & & 314 & 52 & & & Titahi Bay Rd & $16 / 04 / 18$ \\
\hline T1 & Pseudocaranx dentex & Trevally & Arāra, & & 318 & 18 & & & Titahi Bay Rd & $27 / 04 / 18$ \\
\hline T3 & Pseudocaranx dentex & Trevally & & & 329 & 12 & & & Motukarakara Pt Nth & $31 / 05 / 18$ \\
\hline T5 & Pseudocaranx dentex & Trevally & & & 338 & 16 & & & Motukarakara Pt Nth & $15 / 06 / 18$ \\
\hline T6 & Pseudocaranx dentex & Trevally & & & 339 & 18 & & & Motukarakara Pt Nth & $15 / 06 / 18$ \\
\hline K6 & Arripis trutta & Kahawhai & & & 330 & 27 & & & Motukarakara Pt Sth & $1 / 06 / 18$ \\
\hline K7 & Arripis trutta & Kahawhai & & & 331 & 30 & & & Motukarakara Pt Sth & $1 / 06 / 18$ \\
\hline K8 & Arripis trutta & Kahawhai & & & 332 & 25 & & & Motukarakara Pt Sth & $1 / 06 / 18$ \\
\hline
\end{tabular}




\begin{tabular}{|c|c|c|c|c|c|c|c|}
\hline K9 & Arripis trutta & Kahawhai & & 341 & 36 & Motukarakara Pt Sth & $15 / 06 / 18$ \\
\hline K10 & Arripis trutta & Kahawhai & & 337 & 50 & Motukarakara Pt Sth & $15 / 06 / 18$ \\
\hline K11 & Arripis trutta & Kahawhai & & 339 & 49 & Motukarakara Pt Sth & $15 / 06 / 18$ \\
\hline K12 & Arripis trutta & Kahawhai & & 340 & 57 & Motukarakara Pt Sth & $15 / 06 / 18$ \\
\hline H3 & Aldrichetta forsteri & Herring & & 328 & 19 & Motukarakara Pt Nth & $31 / 05 / 18$ \\
\hline H6 & Aldrichetta forsteri & Herring & Aua & 344 & 14 & Motukarakara Pt Nth & $15 / 06 / 18$ \\
\hline H7 & Aldrichetta forsteri & Herring & & 345 & 14 & Motukarakara Pt Nth & $15 / 06 / 18$ \\
\hline H8 & Aldrichetta forsteri & Herring & & 346 & 18 & Motukarakara Pt Nth & $15 / 06 / 18$ \\
\hline H9 & Aldrichetta forsteri & Herring & & 347 & 16 & Motukarakara Pt Nth & $15 / 06 / 18$ \\
\hline S1 & & Spotty & $\begin{array}{l}\text { Paketi, } \\
\text { Pākirikiri }\end{array}$ & 322 & 20 & Onepoto Rpad & $2 / 05 / 18$ \\
\hline S4 & Notolabrus celidotus & Spotty & & 349 & 18 & James Cook Drv & $15 / 06 / 18$ \\
\hline S5 & Notolabrus celidotus & Spotty & & 342 & 16 & Motukarakara Pt Nth & $15 / 06 / 18$ \\
\hline S6 & Notolabrus celidotus & Spotty & & 344 & 14 & Motukarakara Pt Nth & $15 / 06 / 18$ \\
\hline S6 & Notolabrus celidotus & Spotty & & 348 & 18 & Motukarakara Pt Nth & $15 / 06 / 18$ \\
\hline RC1 & Pseudophycis bachus & Red cod & & 334 & 43 & Motukarakara Pt Nth & $15 / 06 / 18$ \\
\hline
\end{tabular}




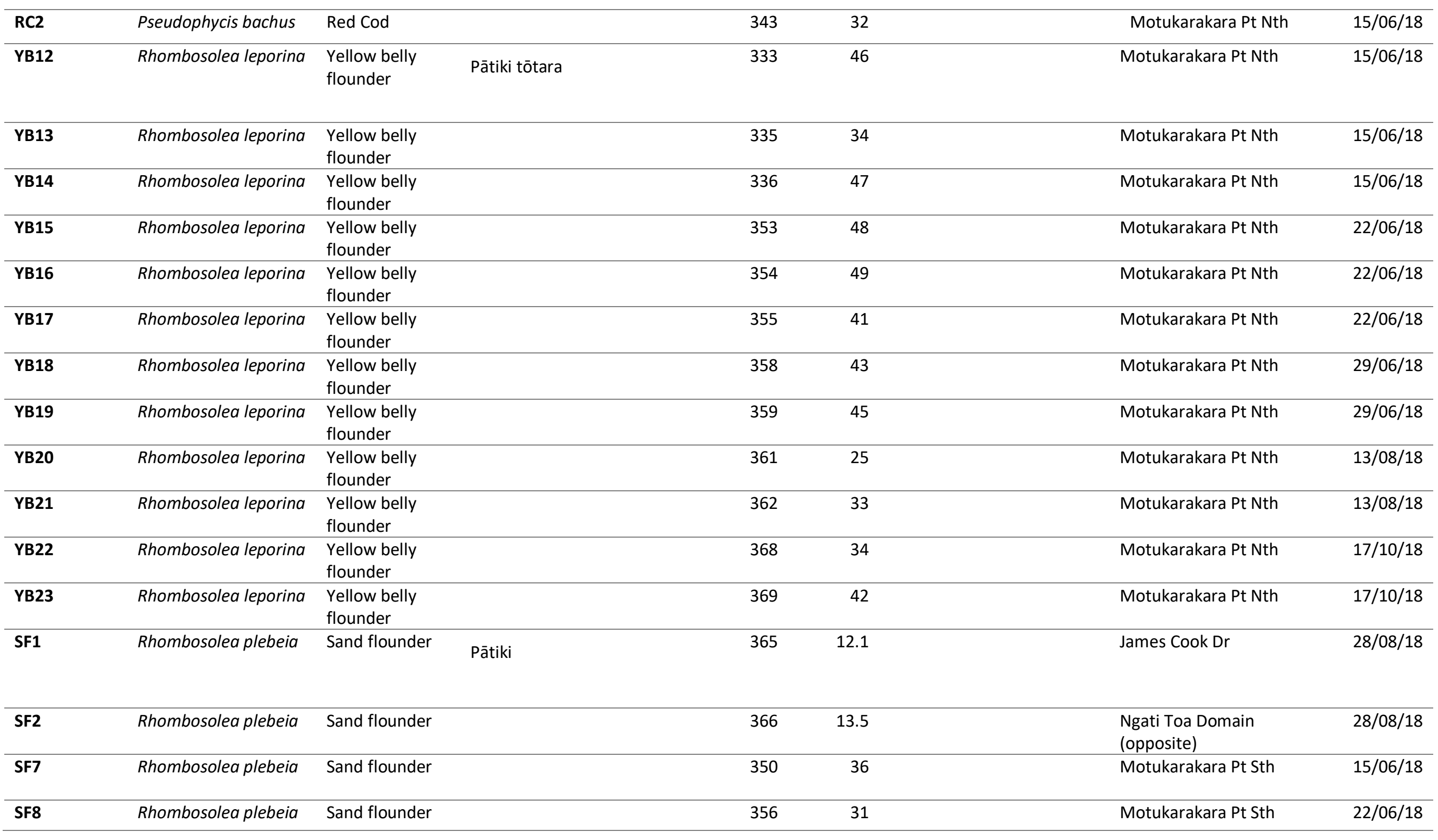




\section{Appendix C}

\section{Parasites and lesions}

Although there was no relationship between parasite/lesions and total heavy metal burden in this present study, they were still observed. Skin abnormalities were observed in 3 flatfish species (figure 3) and a gill leech was found in a speckled sole (figure 4). Although the gill leech has similarities with the leach observed in yellow belly flounder (Burreson et al 2008), formal identification of the gill leech found in this present study was not determined.

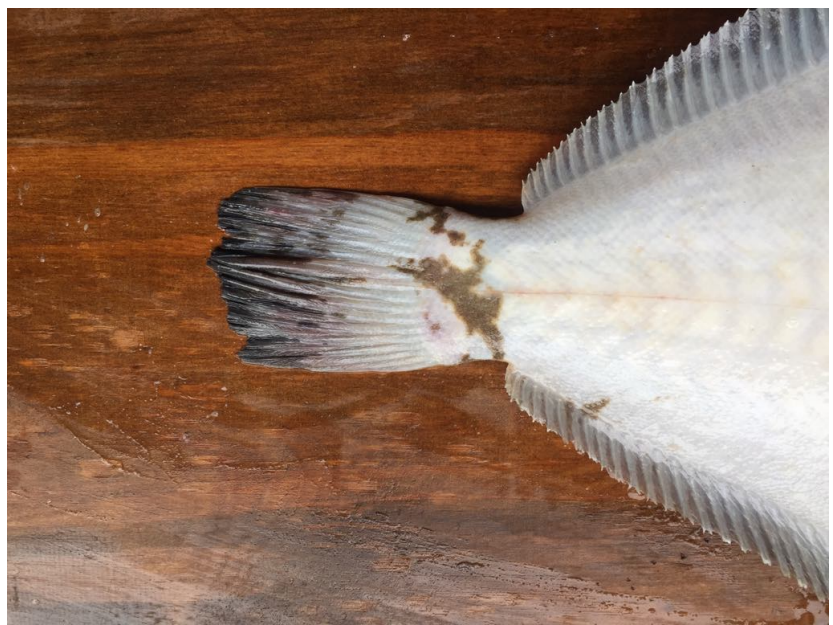

Figure 3: Skin abnormality found on the underside of a female sand flounder collected from Pauatahnui Inlet in 2018

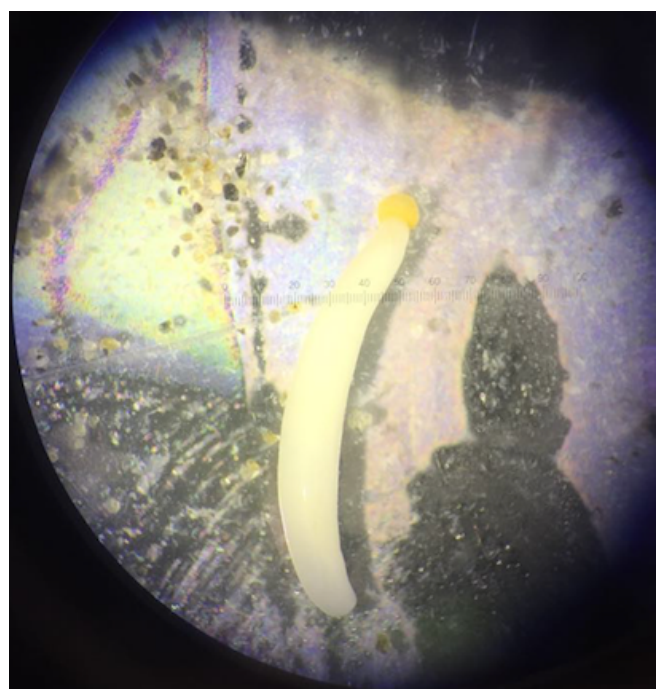

Figure 4: Unidentified gill leech found in a speckled sole, collected at Ngati Toa Domain in 2018. 


\section{Appendix D}

Table 3: Table showing additional measurements taken from rig shark collected from Porirua Harbour in 2018.

\begin{tabular}{|c|c|c|c|c|c|c|c|c|}
\hline $\begin{array}{l}\text { Rig Shark } \\
\text { ID }\end{array}$ & Sex & Weight (KG) & TL (CM) & $\begin{array}{l}\text { First Dorsal } \\
\text { Length (FDL) }\end{array}$ & $\begin{array}{l}\text { Head Length } \\
\text { (HL) }\end{array}$ & $\begin{array}{l}\text { Pre Orbital } \\
\text { Length }\end{array}$ & $\begin{array}{l}\text { Pre Oral } \\
\text { Length }\end{array}$ & $\begin{array}{l}\text { Mouth } \\
\text { Width (MW) }\end{array}$ \\
\hline RS6 & $\mathrm{F}$ & 3.7 & 90 & 28 & 19.5 & 8 & 6 & 5 \\
\hline RS7 & $M$ & 2.37 & 80 & 24 & 16 & 8 & 6 & 5 \\
\hline RS8 & $\mathrm{F}$ & 4.12 & 91 & 29 & 18 & 9 & 6 & 6 \\
\hline RS9 & $F$ & 4.1 & 96 & 30 & 20 & 9.5 & 6 & 5 \\
\hline RS10 & M & 2.9 & 85 & 24 & 15 & 7.5 & 6 & 5 \\
\hline RS11 & $\mathrm{F}$ & 3.4 & 86 & 27 & 16 & 8 & 6 & 5 \\
\hline RS12 & $\mathrm{F}$ & 3.6 & 93 & 29 & 19 & 9 & 6 & 5 \\
\hline RS13 & $\mathrm{F}$ & 3.9 & 91 & 28 & 19 & 9 & 6 & 5 \\
\hline RS14 & $\mathrm{F}$ & 3.5 & 89 & 28 & 18 & 8 & 6 & 4.5 \\
\hline RS22 & $\mathrm{F}$ & 5.2 & 107 & 32 & 19 & 10 & 6 & 7 \\
\hline RS23 & $\mathrm{F}$ & 4.1 & 93 & 30 & 19 & 9 & 6.5 & 6 \\
\hline RS24 & $\mathrm{F}$ & 2.8 & 86 & 28 & 14 & 8 & 6 & 5 \\
\hline RS25 & $\mathrm{F}$ & 2 & 78 & 22 & 14 & 7 & 5 & 4 \\
\hline RS26 & $\mathrm{F}$ & 5.3 & 79 & 25 & 16 & 8 & 5.5 & 5 \\
\hline RS33 & $\mathrm{F}$ & 4 & 95 & 29 & 20 & 10 & 7 & 5 \\
\hline RS34 & $\mathrm{F}$ & 3.1 & 85 & 27 & 18 & 9 & 6.5 & 5 \\
\hline RS35 & $\mathrm{F}$ & 3.2 & 89 & 28 & 17.5 & 9 & 6 & 5 \\
\hline RS37 & $\mathrm{F}$ & 3.3 & 91 & 28 & 18 & 9 & 6 & 5 \\
\hline RS39 & $\mathrm{F}$ & 4 & 96 & 29 & 19 & 10 & 6.5 & 5.5 \\
\hline RS43 & $M$ & 2.4 & 81 & 25 & 16 & 8 & 6 & 4 \\
\hline
\end{tabular}


Table 3: Linear model results of metal comparisons $(\mathrm{Cu}, \mathrm{Zn}, \mathrm{Pb}, \mathrm{Hg})$ across muscle and liver tissue in a) rig shark and, b) flatfish caught in Porirua Harbour 2018. Statistically significant results $p=<0.05$ indicated by*.

A)

\begin{tabular}{|c|c|c|}
\hline Rig shark & $r^{2}$ & p-value \\
\hline $\begin{array}{l}\text { Cu muscle } x \mathrm{Zn} \\
\text { muscle }\end{array}$ & 0.4 & $0.00226^{*}$ \\
\hline $\begin{array}{l}\text { Cu muscle x Zn } \\
\text { liver }\end{array}$ & 0.1293 & 0.1094 \\
\hline Cu liver $x \mathrm{Zn}$ liver & 0.1609 & 0.0715 \\
\hline Cu liver $x \mathrm{Zn}$ muscle & 0.02335 & 0.5085 \\
\hline Cu muscle $x \mathrm{Zn}$ liver & 0.1293 & 0.1094 \\
\hline $\begin{array}{l}\text { Cu muscle x Pb } \\
\text { muscle }\end{array}$ & 0.0314 & 0.4422 \\
\hline Cu muscle x $\mathrm{Pb}$ liver & 0.05228 & 0.3188 \\
\hline $\mathrm{Cu}$ liver $\mathrm{x} \mathrm{Pb}$ muscle & 0.008762 & 0.6865 \\
\hline $\mathrm{Cu}$ liver $\mathrm{x} \mathrm{Pb}$ liver & 0.07562 & 0.2276 \\
\hline $\begin{array}{l}\text { Cu muscle } x \mathrm{Hg} \\
\text { muscle }\end{array}$ & 0.118 & 0.1273 \\
\hline $\begin{array}{l}\text { Cu muscle } \times \mathrm{Hg} \\
\text { liver }\end{array}$ & 0.1669 & 0.06594 \\
\hline $\begin{array}{l}\text { Cu liver } \mathrm{x} \mathrm{Hg} \\
\text { muscle }\end{array}$ & 0.04978 & 0.331 \\
\hline Cu liver $x \mathrm{Hg}$ liver & 0.1295 & 0.1091 \\
\hline $\begin{array}{l}\text { Zn muscle } \times \mathrm{Pb} \\
\text { muscle }\end{array}$ & 0.008909 & 0.684 \\
\hline Zn muscle $\times \mathrm{Pb}$ liver & 0.1423 & 0.09184 \\
\hline $\mathrm{Zn}$ liver $\mathrm{x} \mathrm{Pb}$ liver & 0.71 & $<0.001^{*}$ \\
\hline Zn liver $x \mathrm{~Pb}$ muscle & 0.03501 & 0.4167 \\
\hline $\begin{array}{l}\text { Zn muscle } x \mathrm{Hg} \\
\text { muscle }\end{array}$ & 0.05124 & 0.3238 \\
\hline $\begin{array}{l}\text { Zn muscle x Hg } \\
\text { Liver }\end{array}$ & 0.2115 & $0.03596^{*}$ \\
\hline Zn liver $x \mathrm{Hg}$ liver & 0.224 & $0.03025^{*}$ \\
\hline Zn liver $x \mathrm{Hg}$ muscle & 0.2743 & $0.01482 *$ \\
\hline $\begin{array}{l}\mathrm{Pb} \text { muscle } \times \mathrm{Hg} \\
\text { muscle }\end{array}$ & 0.06233 & 0.2751 \\
\hline $\mathrm{Pb}$ muscle $\times \mathrm{Hg}$ liver & 0.07081 & 0.2436 \\
\hline $\mathrm{Pb}$ liver $\mathrm{x} \mathrm{Hg}$ muscle & 0.1273 & 0.1124 \\
\hline $\mathrm{Pb}$ liver $\times \mathrm{Hg}$ liver & 0.2249 & $0.02986 *$ \\
\hline
\end{tabular}

B)

\begin{tabular}{|c|c|c|}
\hline Flatfish & $r^{2}$ & p-value \\
\hline $\begin{array}{l}\text { Cu muscle } x \mathrm{Zn} \\
\text { muscle }\end{array}$ & 0.66 & $<0.001^{*}$ \\
\hline $\begin{array}{l}\text { Cu muscle } x \mathrm{Zn} \\
\text { liver }\end{array}$ & 0.002155 & 0.8645 \\
\hline Cu liver $x \mathrm{Zn}$ liver & 0.3703 & $0.01237^{*}$ \\
\hline Cu liver $x \mathrm{Zn}$ muscle & 0.04325 & 0.4396 \\
\hline Cu muscle $x \mathrm{Zn}$ liver & 0.002155 & 0.8645 \\
\hline $\begin{array}{l}\text { Cu muscle } \times \mathrm{Pb} \\
\text { muscle }\end{array}$ & 0.07189 & 0.3154 \\
\hline $\begin{array}{l}\text { Cu muscle } \times \mathrm{Pb} \\
\text { liver }\end{array}$ & 0.06491 & 0.341 \\
\hline $\mathrm{Cu}$ liver $\mathrm{x} \mathrm{Pb}$ muscle & 0.02463 & 0.5616 \\
\hline Cu liver $x \mathrm{~Pb}$ liver & 0.1311 & 0.1682 \\
\hline $\begin{array}{l}\text { Cu muscle } \times \mathrm{Hg} \\
\text { muscle }\end{array}$ & 0.08922 & 0.2611 \\
\hline Cu muscle $x \mathrm{Hg}$ liver & 0.08802 & 0.2645 \\
\hline $\mathrm{Cu}$ liver $\mathrm{x} \mathrm{Hg}$ muscle & 0.269 & $0.03956 *$ \\
\hline Cu liver $x$ Hg liver & 0.5061 & 0.001999* \\
\hline $\begin{array}{l}\text { Zn muscle } \times \mathrm{Pb} \\
\text { muscle }\end{array}$ & 0.0633 & 0.3472 \\
\hline Zn muscle $\times \mathrm{Pb}$ liver & 0.0686 & 0.3271 \\
\hline Zn liver $x \mathrm{~Pb}$ liver & 0.1426 & 0.1493 \\
\hline Zn liver $x \mathrm{~Pb}$ muscle & 0.11 & 0.2096 \\
\hline $\begin{array}{l}\text { Zn muscle } x \mathrm{hg} \\
\text { muscle }\end{array}$ & 0.115 & 0.1989 \\
\hline Zn muscle $\mathrm{x}$ hg liver & 0.09169 & 0.2543 \\
\hline Zn liver $x \mathrm{Hg}$ liver & 0.01299 & 0.6743 \\
\hline Zn liver $x \mathrm{Hg}$ muscle & -0.001 & 0.979 \\
\hline $\begin{array}{l}\mathrm{Pb} \text { muscle } \times \mathrm{Hg} \\
\text { muscle }\end{array}$ & 0.02262 & 0.5782 \\
\hline $\mathrm{Pb}$ muscle $\times \mathrm{Hg}$ liver & 0.01728 & 0.6275 \\
\hline $\mathrm{Pb}$ liver $\mathrm{x} \mathrm{Hg}$ muscle & 0.006931 & 0.7592 \\
\hline $\mathrm{PbL}$ liver $\mathrm{x} \mathrm{Hg}$ liver & 0.01804 & 0.6199 \\
\hline
\end{tabular}




\section{Appendix $F$}

Table 4: Table showing TL range of maternal rig shark and their embryos and mean \pm standard deviation of heavy metal concentration in maternal rig shark and their embryos.

\begin{tabular}{|c|c|c|c|c|c|c|c|c|c|c|c|c|c|c|c|c|}
\hline \multirow[b]{2}{*}{$\begin{array}{l}\text { TL of } \\
\text { mother }\end{array}$} & \multirow[b]{2}{*}{$\begin{array}{l}\text { TL } \\
\text { range } \\
\text { of } \\
\text { pups }\end{array}$} & \multirow[b]{2}{*}{ Male } & \multirow[b]{2}{*}{ Female } & \multicolumn{3}{|c|}{$\begin{array}{l}\text { Liver concentration } \\
\text { mother }\end{array}$} & \multicolumn{5}{|c|}{$\begin{array}{l}\text { Muscle concentration } \\
\text { mother }\end{array}$} & \multicolumn{5}{|c|}{$\begin{array}{l}\text { Mean Pup muscle concentration with } \\
\text { standard deviation }\end{array}$} \\
\hline & & & & Total & $\mathrm{cu}$ & $\mathrm{Zn}$ & $\mathrm{Pb}$ & $\mathrm{Hg}$ & $\mathrm{Cu}$ & $\mathrm{Zn}$ & $\mathrm{Pb}$ & $\mathrm{Hg}$ & $\mathrm{Cu}$ & $\mathrm{Zn}$ & $\mathrm{Pb}$ & hg \\
\hline 85 & $18-19$ & 3 & 2 & 5 & 3.57 & 28.6 & 0.09 & 0.15 & 0.63 & 19.3 & 0.11 & 1.06 & $\begin{array}{l}3.09 \pm \\
0.676\end{array}$ & $\begin{array}{l}57.7 \pm \\
3.673\end{array}$ & $\begin{array}{l}0.08 \pm \\
0.0228\end{array}$ & $\begin{array}{l}0.099 \pm \\
0.0114\end{array}$ \\
\hline 89 & $16-17$ & 3 & 4 & 7 & 2.61 & 16.5 & 0.07 & 0.09 & 1.51 & 17.6 & 0.09 & 0.79 & $\begin{array}{l}3.3 \pm \\
0.753\end{array}$ & $\begin{array}{l}58.4 \pm \\
6.249\end{array}$ & $\begin{array}{l}0.06 \pm \\
0.017\end{array}$ & $\begin{array}{l}0.07 \pm \\
0.007\end{array}$ \\
\hline 91 & $14-17$ & 2 & 4 & 6 & 3.3 & 15.5 & 0.14 & 0.4 & 1.13 & 15.8 & 0.11 & 1.57 & $\begin{array}{l}5.22 \pm \\
0.532\end{array}$ & $\begin{array}{l}51 \pm \\
5.237\end{array}$ & $\begin{array}{l}0.14 \pm \\
0.079\end{array}$ & $\begin{array}{l}0.11 \pm \\
0.029\end{array}$ \\
\hline
\end{tabular}




\begin{tabular}{|c|c|c|c|c|c|c|c|c|c|c|c|c|c|c|c|c|}
\hline \multirow[t]{2}{*}{91} & $12-13$ & 1 & 6 & 7 & 4.15 & 45.8 & 0.21 & 0.33 & 0.73 & 14.5 & 0.07 & 1.45 & $3.81 \pm$ & $58.4 \pm$ & $0.15 \pm$ & $0.13 \pm$ \\
\hline & & & & & & & & & & & & & 0.7532 & 6.174 & 0.119 & 0.101 \\
\hline \multirow[t]{2}{*}{93} & 14 & 1 & 1 & 2 & 2.99 & 32.9 & 0.26 & 0.42 & 0.59 & 13.5 & 0.1 & 2.68 & $3.26 \pm$ & 53.1 & $0.06 \pm$ & $0.32 \pm$ \\
\hline & & & & & & & & & & & & & 0.121 & \pm 1.061 & 0 & 0.009 \\
\hline \multirow[t]{2}{*}{95} & $13-14$ & 2 & 4 & 5 & 4.77 & 19.7 & 0.12 & 0.51 & 0.92 & 14.8 & 0.12 & 1.27 & $14.3 \pm$ & $62.4 \pm$ & $0.25 \pm$ & $0.16 \pm$ \\
\hline & & & & & & & & & & & & & 5.419 & 8.810 & 0.0562 & 0.028 \\
\hline \multirow[t]{2}{*}{90} & $11-14$ & 4 & 3 & 7 & 7.02 & 27.7 & 0.08 & 0.31 & 0.47 & 12.3 & 0.08 & 1.31 & $3.29 \pm$ & $58.4 \pm$ & $0.17 \pm$ & $0.07 \pm$ \\
\hline & & & & & & & & & & & & & 0.608 & 3.683 & 0.068 & 0.027 \\
\hline \multirow[t]{2}{*}{89} & $14-16$ & 3 & 3 & 6 & 4.57 & 28.6 & 0.12 & 0.29 & 0.58 & 12.7 & 0.07 & 5.81 & $6.45 \pm$ & $70.2 \pm$ & $0.28 \pm$ & $0.23 \pm$ \\
\hline & & & & & & & & & & & & & 2.499 & 7.201 & 0.076 & 0.043 \\
\hline \multirow[t]{2}{*}{79} & 16 & - & 2 & 2 & 4.91 & 0.09 & 0.09 & 9.84 & 1.6 & 18.1 & 0.07 & 0.71 & $4.84 \pm$ & $59 \pm$ & $0.13 \pm$ & $0.87 \pm$ \\
\hline & & & & & & & & & & & & & 2.084 & 4.009 & 0.041 & 0.151 \\
\hline \multirow[t]{2}{*}{96} & $13-14$ & 4 & 2 & 6 & 4.2 & 20.4 & 0.08 & 0.14 & 1.07 & 15.6 & 0.08 & 1.66 & $5.23 \pm$ & $74.2 \pm$ & $0.12 \pm$ & $0.09 \pm$ \\
\hline & & & & & & & & & & & & & 1.747 & 3.959 & 0.021 & 0.0098 \\
\hline \multirow[t]{3}{*}{107} & $20-21$ & 3 & 2 & 5 & 4.08 & 21.6 & 0.14 & 0.63 & 1.6 & 18.1 & 0.07 & 0.71 & $3.9 \pm$ & $43 \pm$ & $0.01 \pm$ & $0.24 \pm$ \\
\hline & & & & & & & & & & & & & 0.689 & 3.365 & & 0.043 \\
\hline & & & & & & & & & & & & & & & 0.012 & \\
\hline \multirow[t]{2}{*}{93} & $16-18$ & 1 & 5 & 6 & 3.52 & 23.4 & 0.11 & 0.53 & 1.28 & 14.5 & 0.08 & 2.23 & $3.02 \pm$ & $49.55 \pm$ & $0.1 \pm$ & $0.24 \pm$ \\
\hline & & & & & & & & & & & & & 0.483 & 3.824 & 0.011 & 0.04339 \\
\hline
\end{tabular}




\section{Appendix G}

\section{Potential stingray and $\mathrm{Pb}$ relationship}

Due to a small sample size, no relationship between ray heavy metal data and biological characteristics such as TL, disk length, etc. were obtained. However, (figure 5) show a potential relationship between $\mathrm{Pb}$ muscle concentrations and disk length in female eagle ray. However, further research with a larger sample size will be needed in order to conclude this.

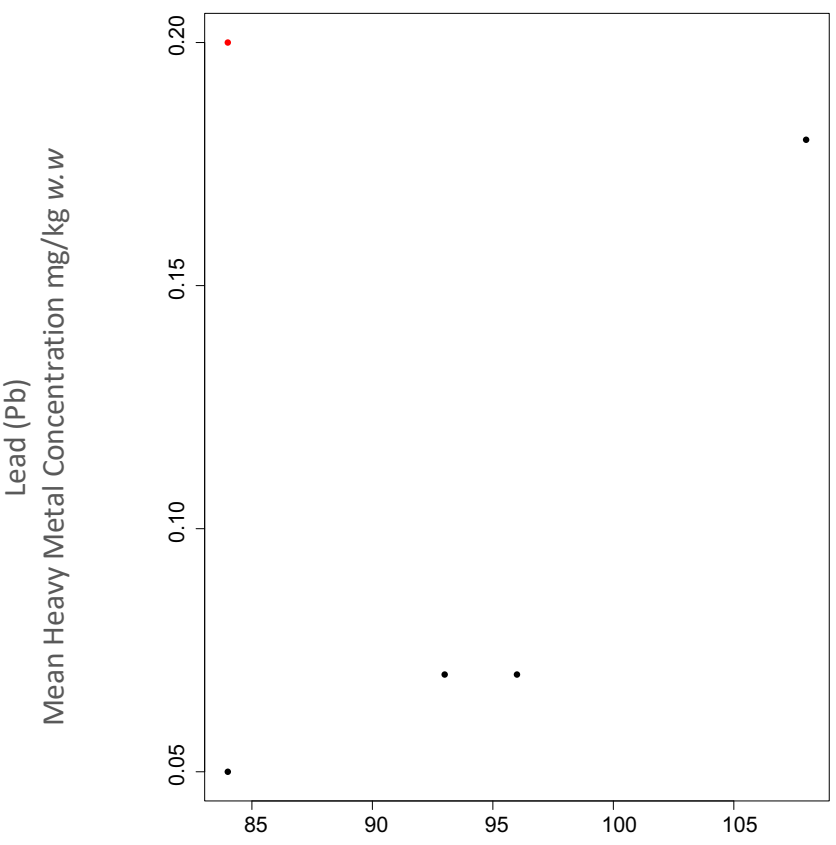

Disc Width (DW)

Figure 5: Scatterplot showing the relationship between muscle $\mathrm{Pb}$ concentration and disc width (DW) for short-tailed stingray (red), and eagle ray (black), caught in Porirua Harbour in 2018. 